Portland State University

PDXScholar

Spring 5-16-2013

\title{
Innovation Measurement: a Decision Framework to Determine Innovativeness of a Company
}

Kenny Phan

Portland State University

Follow this and additional works at: https://pdxscholar.library.pdx.edu/open_access_etds

Part of the Industrial Technology Commons, and the Technology and Innovation Commons Let us know how access to this document benefits you.

\section{Recommended Citation}

Phan, Kenny, "Innovation Measurement: a Decision Framework to Determine Innovativeness of a Company" (2013). Dissertations and Theses. Paper 1017.

https://doi.org/10.15760/etd.1017

This Dissertation is brought to you for free and open access. It has been accepted for inclusion in Dissertations and Theses by an authorized administrator of PDXScholar. Please contact us if we can make this document more accessible: pdxscholar@pdx.edu. 
Innovation Measurement:

A Decision Framework to Determine Innovativeness of a Company

\author{
by \\ Kenny Phan
}

A dissertation submitted in partial fulfillment of the requirements for the degree of

\author{
Doctor of Philosophy \\ in \\ Technology Management
}

Dissertation Committee:

Dundar F. Kocaoglu, Chair

Tugrul U. Daim

Robert D. Dryden

Charla Mathwick

Wayne Wakeland

Ellen West

Portland State University

2013 
(C) 2013 Kenny Phan 


\begin{abstract}
Innovation is one of the most important sources of competitive advantage. It helps a company to fuel the growth of new products and services, sustain incumbents, create new markets, transform industries, and promote the global competitiveness of nations. Because of its importance, companies need to manage innovation. It is very important for a company to be able to measure its innovativeness because one cannot effectively manage without measurement. A good measurement model will help a company to understand its current capability and identify areas that need improvement.

In this research a systematic approach was developed for a company to measure its innovativeness. The measurement of innovativeness is based on output indicators. Output indicators are used because they cannot be manipulated. A hierarchical decision model (HDM) was constructed from output indicators. The hierarchy consisted of three levels: innovativeness index, output indicators and sub-factors.

Experts' opinions were collected and quantified. A new concept developed by Dr. Dundar Kocaoglu and referred to as "desirability functions" was implemented in this research.

Inconsistency of individual experts, disagreement among experts, intraclass correlation coefficients and statistical F-tests were calculated to test the reliability of the experts' judgments. Sensitivity analysis was used to test the sensitivity of the output indicators, which indicated the allowable range of the changes in the output indicators in order to maintain the priority of the sub-factors.
\end{abstract}


The outcome of this research is a decision model/framework that provides an innovativeness index based on readily measurable company output indicators.

The model was applied to product innovation in the technology-driven semiconductor industry. Five hypothetical companies were developed to simulate the application of the model/framework. The profiles of the hypothetical companies were varied considerably to provide a deeper understanding of the model/framework. Actual data from two major corporations in the semiconductor industry were then used to demonstrate the application of the model.

According to the experts, the top three sub-factors to measure the innovativeness of a company are revenue from new products (28\%), market share of new products (21\%), and products that are new to the world (20\%). 


\section{Dedication}

This dissertation is dedicated to everyone who believes in hard work and education. 


\section{Acknowledgments}

I would like to express my immense gratitude, first and foremost, to my committee chair and PhD advisor, Dr. Dundar F. Kocaoglu, who continuously supported and guided me through the completion of this dissertation. His support in many forms gave me strength and confidence. Without his guidance and persistent help, this dissertation would not have been possible.

I cannot find words to express my gratitude to my master's degree advisor, Dr. Tugrul U. Daim, for convincing me to continue my studies at the doctoral level. His endless encouragement helped me through the PhD process.

It is also with great gratitude that I acknowledge the support of my committee members, Dr. Robert D. Dryden, Dr. Charla Mathwick, Dr. Wayne Wakeland, and Dr. Ellen West, for their valuable time and efforts during the completion of my dissertation. Their constructive comments added to and enhanced the contribution of my dissertation.

I owe my gratitude to the faculty members of the Department of Engineering and Technology Management, Dr. Timothy R. Anderson, Dr. Antonie J. Jetter, and Dr. Charles M. Weber, for their wonderful support, advice, and encouragement. Their courses well prepared me for the dissertation process.

I am truly indebted and thankful to Liono Setiowijoso, who introduced the Department of Engineering and Technology Management to me. His infinite support from the start until the end made it all possible. 
I owe sincere thankfulness to Ann White for helping me with the editorial work for my dissertation. I appreciate the amount of time she spent reading my dissertation and her endless support throughout the entire process.

I would like express my immense appreciation to Shawn Wall for her constant support and help in the office. Without her assistance, promptness, and flexibility, the process would not have gone as smoothly as it did.

I would like to say a million thanks to Donna Koch for always jumping in and giving me wonderful advice during difficult times. Her kindness, caring, and wisdom helped me to remain resolute during my dissertation process.

I am grateful to the experts who participated in my dissertation. Without their inputs and valuable insights, the findings of my research would not have been possible, and I thank them for their efforts and time throughout the entire process.

I would like to express my deepest gratitude to my beloved parents, Pang Ciung Tiong and Sea Sai Khim, for believing in me. They pushed me out of my comfort zone and convinced me that I could accomplish this goal. Their blessing and support are what kept me steadfast until the end. I will be forever grateful for their love.

I am grateful for my dear sister, Diana; my dear brother, Hendrik Phan; my brother-in-law, Edy Salim; my lovely niece and nephew, Ella Lim and Devon Lim; my aunt, Pang Ai Ping; and my grandmother, Giok Hwa, for cheering me on and supporting me when I was in the process of writing my dissertation. Their words of encouragement helped me to persevere until the end of the process. 
I offer thanks to my fellow students, especially my office mates, Songphon Munkongsujarit, Pattharaporn Suntharasaj, Pattravadee Ploykitikoon, Inthrayuth Mahapol, and Jiting Yang, for always being there for me when I needed them. Their encouragement and reassurances made me realize that I was not alone.

I thank the staff in the Office of Graduate Studies, Portland State University, for their steady support. Their professionalism made the process a lot easier.

I would like to acknowledge the staff in the Office of International Students, especially Christina Luther, for help with immigration questions.

Finally, I want to express my gratitude to my friends and family, whose names are too many to list here, for their abundant encouragement and their warm and sincere good wishes. Without all of them as my support system, the process would not have been as easy. 
Table of Contents

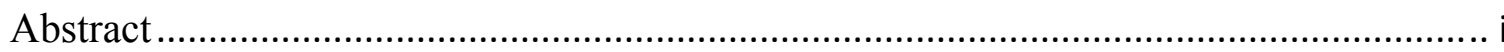

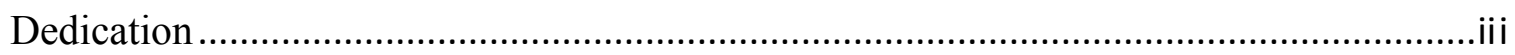

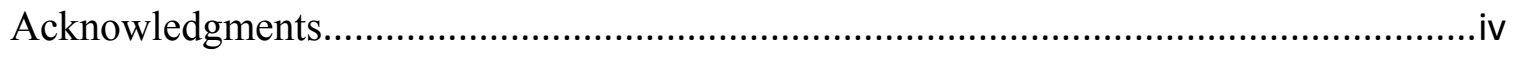

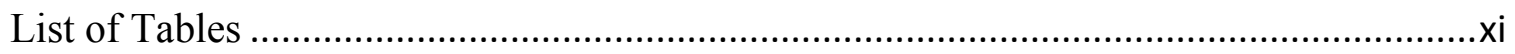

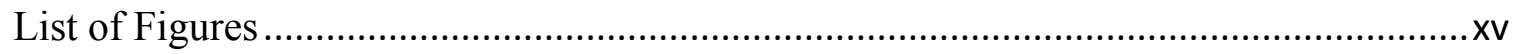

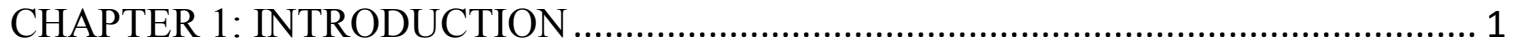

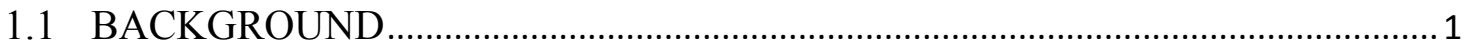

1.2 RESEARCH SCOPE, OBJECTIVE, APPROACH, OUTCOMES/ CONTRIBUTIONS AND APPLICATION ....................................................... 6

CHAPTER 2: LITERATURE REVIEW …................................................................ 9

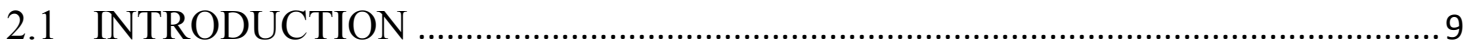

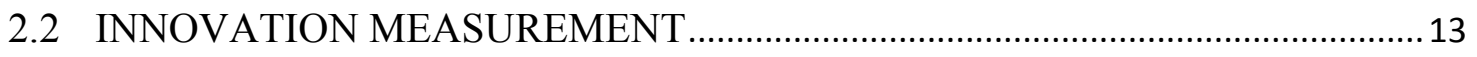

2.2.1 Input and output as foci of innovation measurement......................................... 13

2.2.2 Metrics and methodologies for measuring innovation. .................................... 16

2.2.3 Used of multi-dimensional approaches to measure multi-attributes of

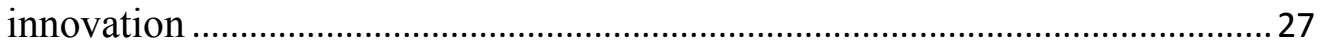

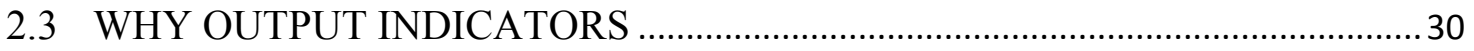

2.4 OUTPUT INDICATORS FOR INNOVATION MEASUREMENT ....................... 32

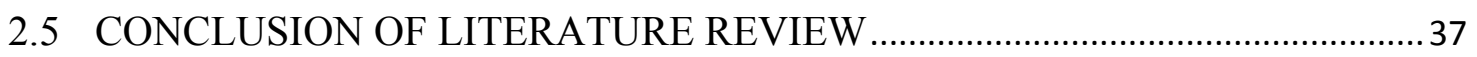

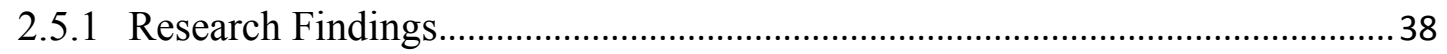

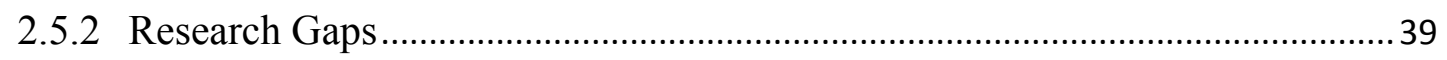

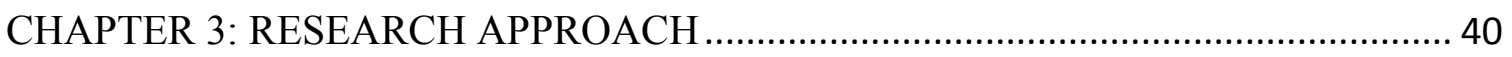

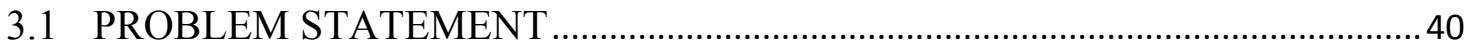

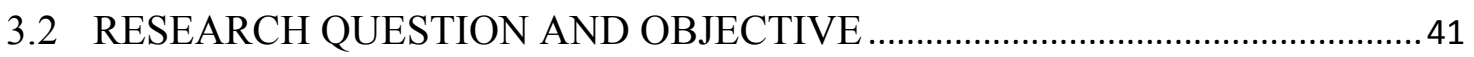

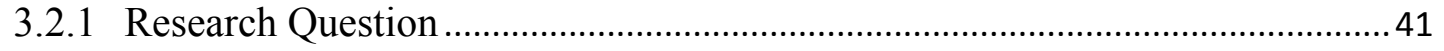

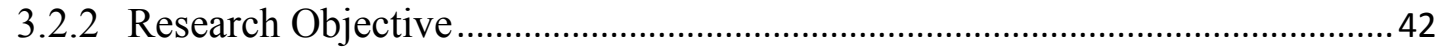

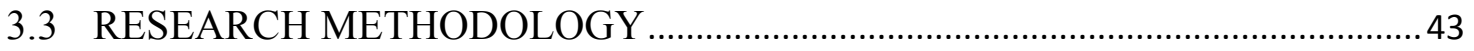

3.3.1 Hierarchical Decision Model (HDM) ............................................................. 43

vii 


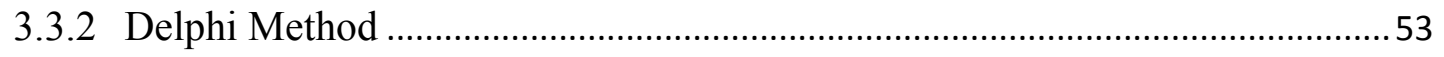

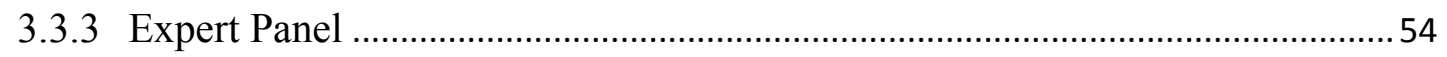

3.4 IMPLEMENTING THE RESEARCH APPROACH IN A SPECIFIC CASE ......57

3.5 VALIDATION OF THE RESEARCH ..................................................................58

CHAPTER 4: RESEARCH APPLICATION …………………………………........ 59

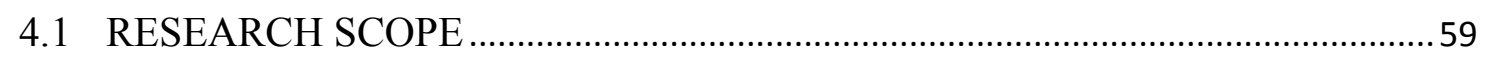

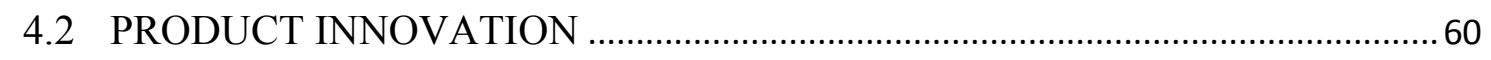

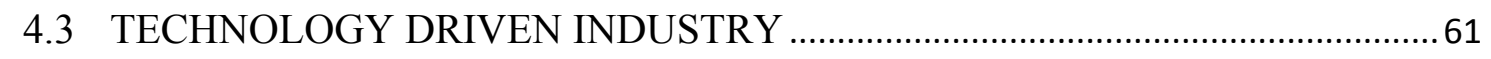

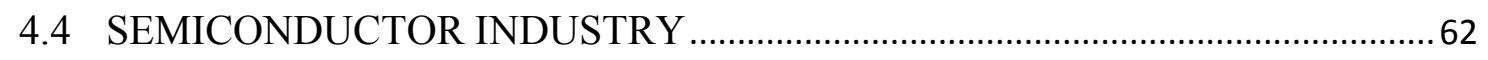

CHAPTER 5: EXPERT PANELS FORMATION, MODEL DEVELOPMENT AND

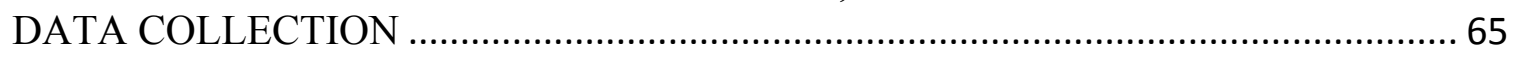

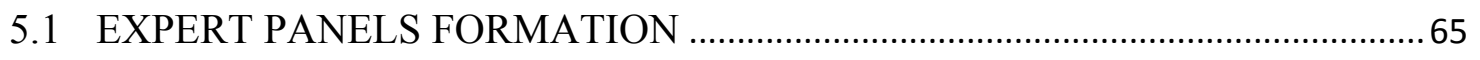

5.1.1 Criteria to Select Expert Panel Members ……………………………………...66

5.1.2 Expert Panels Profile ……………………………………………………….......

5.1.3 Obtaining Consent and Collecting Data from Experts ……………………....... 74

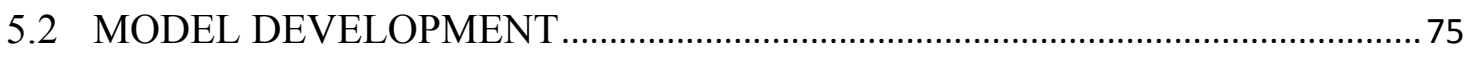

5.2.1 Mission Level ..........................................................................................

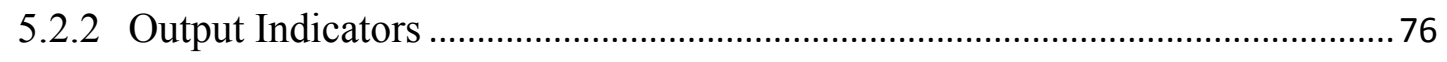

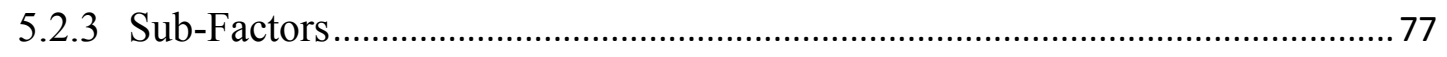

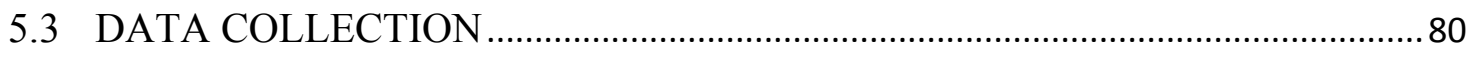

5.4 SUMMARY OF DATA COLLECTION PROCESS ……………………………....83

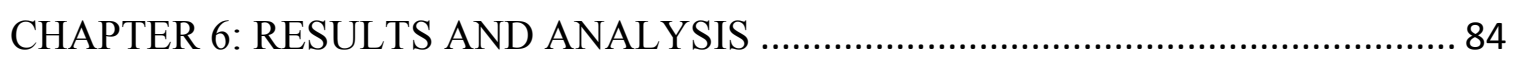

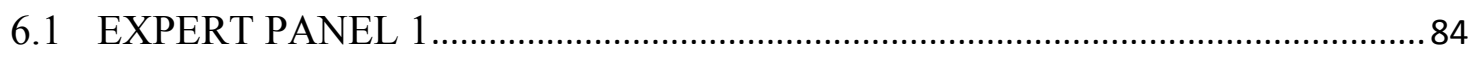

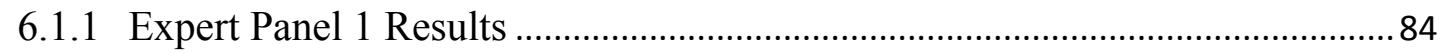

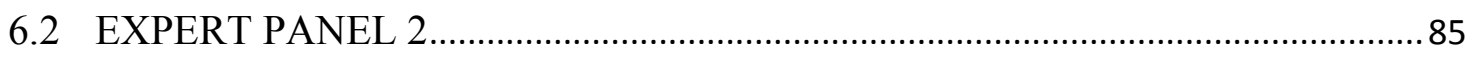

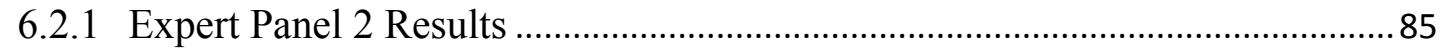

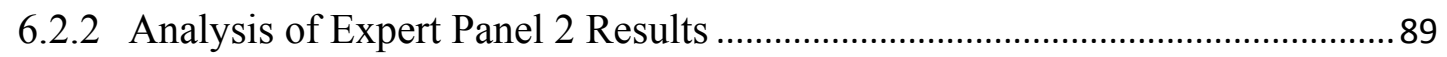

6.2.3 Validation of Data - Expert Panel 2............................................................... 107

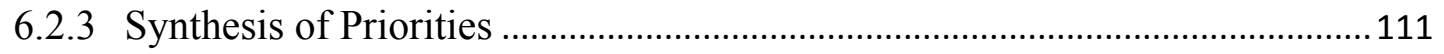

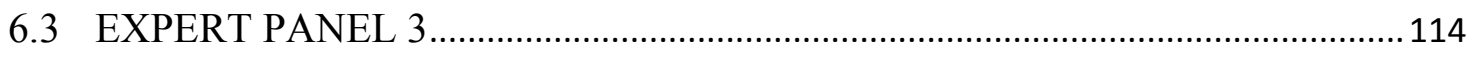

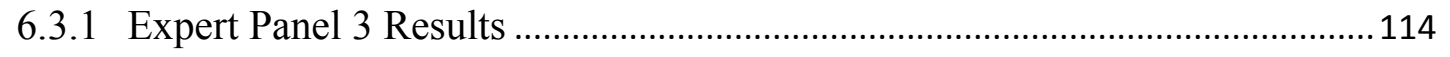

6.3.2 Analysis and Validation of Expert Panel 3 Results..........................................120 


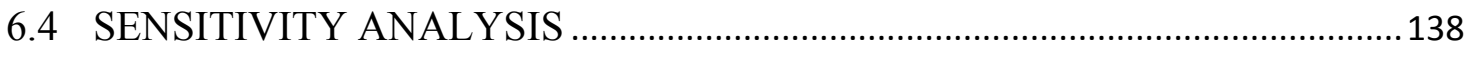

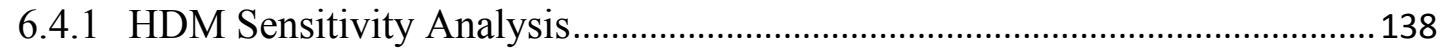

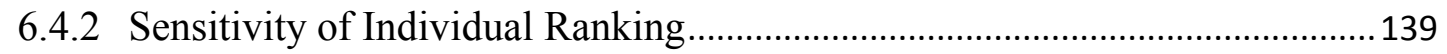

6.4.3 Sensitivity of Group Ranking ...................................................................... 141

6.5 SIMULATED APPLICATION OF THE MODEL ……………………………....142

6.5.1 Changes in Relative Importance of the Output Indicators ................................ 147

6.5.2 Changes in the Performance Metrics of the Companies..................................... 153

6.5.3 Innovativeness Index of Intel and AMD ......................................................... 158

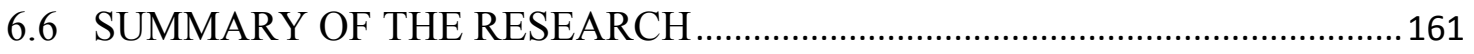

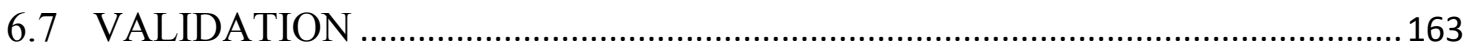

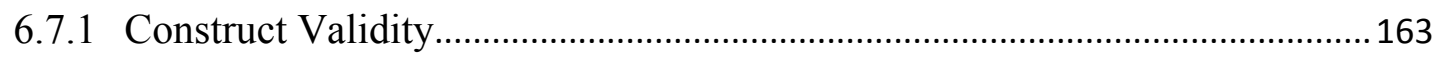

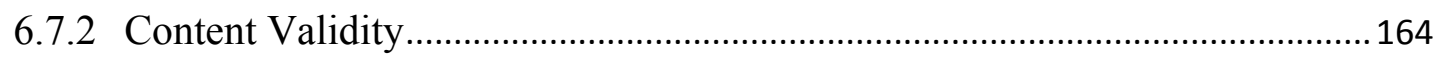

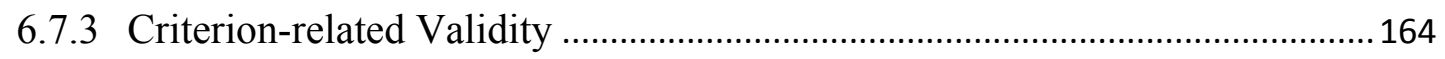

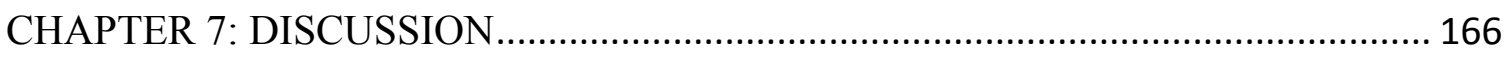

7.1 CONCLUSIONS AND CONTRIBUTIONS …………………………………....... 166

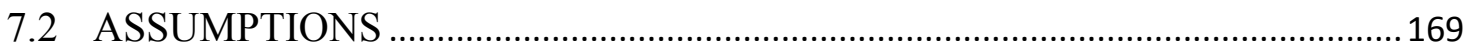

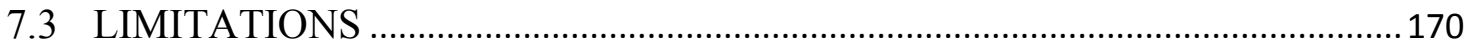

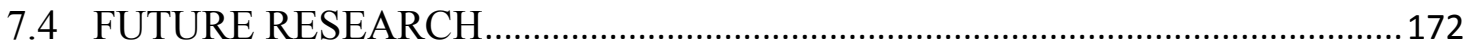

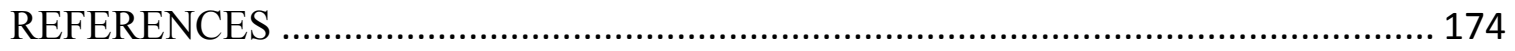

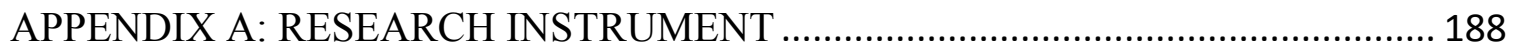

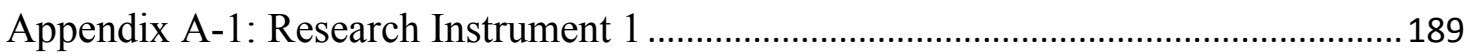

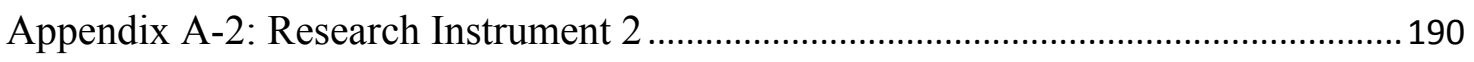

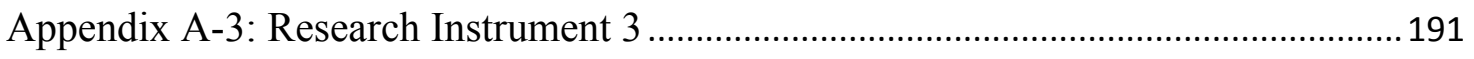

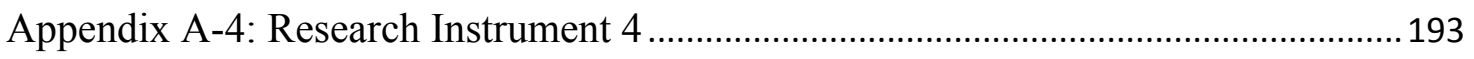

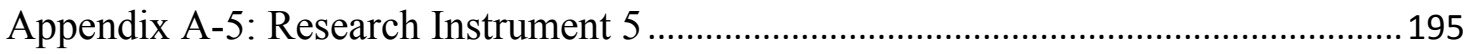

Appendix A-6: Research Instrument 6 ....................................................................... 197

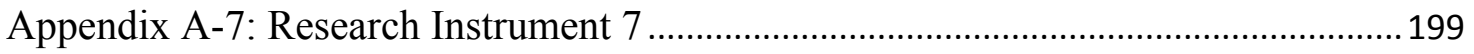

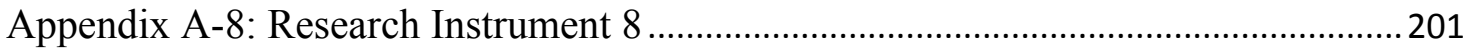

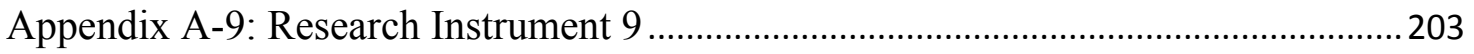

Appendix A-10: Research Instrument 10................................................................... 205

Appendix A-11: Research Instrument 11 ..................................................................... 207

Appendix A-12: Research Instrument 12 ................................................................... 


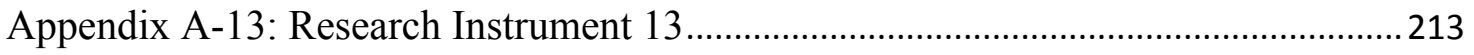

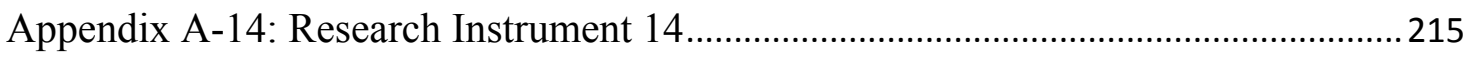

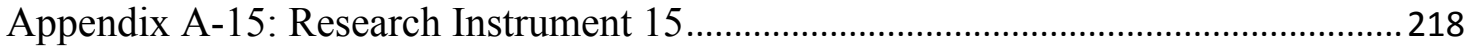

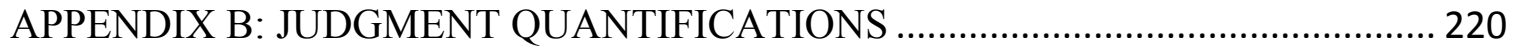

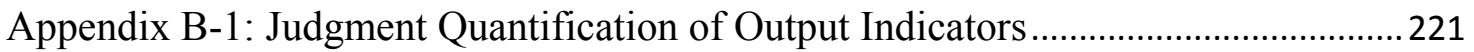

Appendix B-2: Judgment Quantification of Sub-Factors of Number of New Products

Appendix B-3: Judgment Quantification of Sub-Factors of Number of Innovation

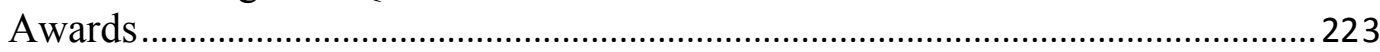

Appendix B-4: Judgment Quantification of Sub-Factors of Number of Patents .......... 224

Appendix B-5: Judgment Quantification of Sub-Factors of Number of Publications . 225

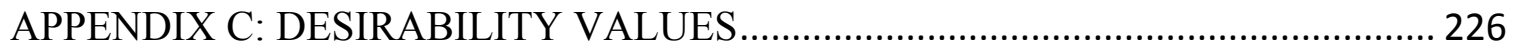

Appendix C-1: Desirability Values of Number of New Products ……...........................227

Appendix C-2: Desirability Values of Number of Innovation Awards ..........................228

Appendix C-3: Desirability Values of Number of Patents ............................................. 229

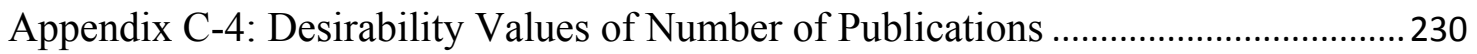

Appendix C-5: Desirability Values of Revenue of New Products .................................. 231

Appendix C-6: Desirability Values of Market Share of New Products ......................... 232

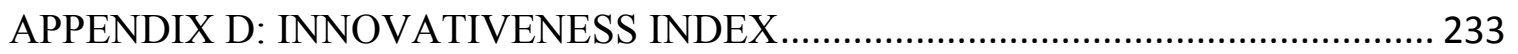

Appendix D-1: Innovativeness Index - Baseline Value ............................................. 234

Appendix D-2: Innovativeness Index - Changes in Relative Importance of Sub-factors

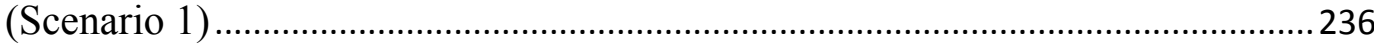

Appendix D-3: Innovativeness Index - Changes in Relative Importance of sub-factors

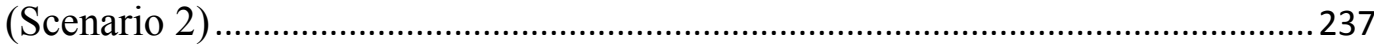

Appendix D-4: Innovativeness Index - Changes in Relative Importance of sub-factors

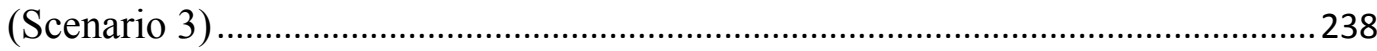

Appendix D-5: Innovativeness Index - Changes in Relative Importance of sub-factors

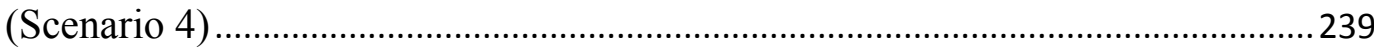

Appendix D-6: Innovativeness Index - Changes in Company Outputs (Scenario 5).. 240

Appendix D-7: Innovativeness Index - Changes in Company Outputs (Scenario 6) .. 241

Appendix D-8: Innovativeness Index - Changes in Company Outputs (Scenario 7).. 242

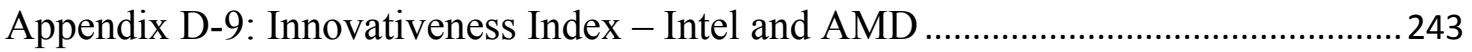


List of Tables

TABLE 2. 1 METHODOLOGIES IN INNOVATION MEASUREMENT FROM

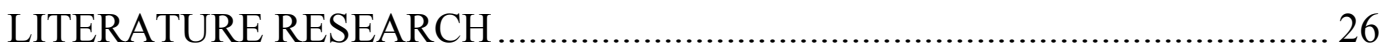

TABLE 2.2 OUTPUT INDICATORS FROM LITERATURE RESEARCH................. 34

TABLE 2.3 FINDINGS OF INNOVATION MEASUREMENT FROM THE

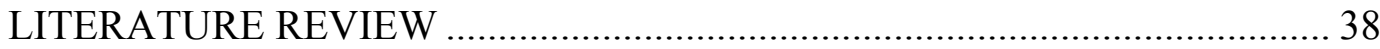

TABLE 5.1 DISTRIBUTION AND BACKGROUND OF EXPERT PANEL 1.............. 71

TABLE 5.2 DISTRIBUTION AND BACKGROUND OF EXPERT PANEL 2............. 72

TABLE 5.3 DISTRIBUTION AND BACKGROUND OF EXPERT PANEL 3............. 74

TABLE 6.1 THE RELATIVE IMPORTANCE AND INCONSISTENCY OF OUTPUT INDICATORS FROM 36 EXPERTS IN EXPERT PANEL 2 ………………...... 90

TABLE 6.2 INTRACLASS CORRELATION COEFFICIENT OF OUTPUT INDICATORS FROM EXPERT PANEL 2 ………....................................... 92

TABLE 6.3 THE RELATIVE IMPORTANCE AND INCONSISTENCY OF OUTPUT INDICATORS FROM THE 1ST SUBGROUP ……………………………..... 93

TABLE 6.4 INTRACLASS CORRELATION COEFFICIENT OF OUTPUT INDICATORS FROM THE 1ST SUBGROUP ................................................. 93

TABLE 6.5 THE RELATIVE IMPORTANCE AND INCONSISTENCY OF OUTPUT INDICATORS FROM THE 2ND SUBGROUP …………………………….... 94

TABLE 6.6 INTRACLASS CORRELATION COEFFICIENT OF OUTPUT INDICATORS FROM THE 2ND SUBGROUP …………………………...... 94

TABLE 6.7 THE RELATIVE IMPORTANCE AND INCONSISTENCY OF OUTPUT INDICATORS FROM THE $3^{\text {RD }}$ SUBGROUP …………………………….... 95

TABLE 6.8 INTRACLASS CORRELATION COEFFICIENT OF OUTPUT INDICATORS FROM THE $3^{\text {RD }}$ SUBGROUP ………….............................. 95

TABLE 6.9 THE RELATIVE IMPORTANCE AND INCONSISTENCY OF OUTPUT INDICATORS FROM THE $4{ }^{\mathrm{TH}}$ SUBGROUP ………....................................... 96

TABLE 6.10 INTRACLASS CORRELATION COEFFICIENT OF OUTPUT INDICATORS FROM THE $4{ }^{\mathrm{TH}}$ SUBGROUP ……........................................... 96

TABLE 6.11 COMPARISONS OF RELATIVE IMPORTANCE, DISAGREEMENT, AND INTRACLASS CORRELATION BEFORE AND AFTER CLUSTERING

TABLE 6.12 THE RELATIVE IMPORTANCE AND INCONSISTENCY OF SUBFACTORS OF NUMBER OF NEW PRODUCTS FROM EXPERT PANEL 2. 99 TABLE 6.13 INTRACLASS CORRELATION COEFFICIENT OF SUB-FACTORS OF NUMBER OF NEW PRODUCTS 100

TABLE 6.14 THE RELATIVE IMPORTANCE AND INCONSISTENCY OF SUB FACTORS OF NUMBER OF INNOVATION AWARDS FROM EXPERT PANEL 2 101 
TABLE 6.15 THE RELATIVE IMPORTANCE AND INCONSISTENCY OF SUBFACTORS OF NUMBER OF PATENTS FROM EXPERT PANEL 2 …......... 102 TABLE 6.16 INTRACLASS CORRELATION COEFFICIENT OF SUB-FACTORS OF NUMBER OF PATENTS. 104

TABLE 6.17 THE RELATIVE IMPORTANCE AND INCONSISTENCY OF SUB-

FACTORS OF NUMBER OF PUBLICATIONS FROM EXPERT PANEL 2. 105

TABLE 6.18 INTRACLASS CORRELATION COEFFICIENT OF SUB-FACTORS OF NUMBER OF NEW PUBLICATIONS 106

TABLE 6.19 THE RELATIVE CONTRIBUTION OF SUB-FACTORS TO THE INNOVATIVENESS INDEX 112

TABLE 6.20 THE RELATIVE CONTRIBUTION OF SUB-FACTORS TO THE INNOVATIVENESS INDEX FROM ALL EXPERTS AND FOUR SUBGROUPS AND RANKING OF THE SUB-FACTORS.

TABLE 6.21 DESIRABILITY VALUES - NUMBER OF NEW PRODUCTS NEW TO THE WORLD 115

TABLE 6.22 DESIRABILITY VALUES - NUMBER OF NEW PRODUCTS NEW TO THE COMPANY 115

TABLE 6.23 DESIRABILITY VALUES - NUMBER OF INNOVATION AWARDS 116

TABLE 6.24 DESIRABILITY VALUES - NUMBER OF INNOVATION HONORS 116 TABLE 6.25 DESIRABILITY VALUES - NUMBER OF PATENTS FILED ............ 117 TABLE 6.26 DESIRABILITY VALUES - NUMBER OF PATENTS GRANTED .... 117 TABLE 6.27 DESIRABILITY VALUES - NUMBER OF PATENTS CITED ............. 117 TABLE 6.28 DESIRABILITY VALUES - NUMBER OF PAPERS PUBLISHED .... 118 TABLE 6.29 DESIRABILITY VALUES - NUMBER OF PAPERS CITED................ 118 TABLE 6.30 DESIRABILITY VALUES - NUMBER OF PAPERS PRESENTED .... 119 TABLE 6.31 DESIRABILITY VALUES - REVENUE FROM NEW PRODUCTS ... 119 TABLE 6.32 DESIRABILITY VALUES -MARKET SHARE FROM NEW PRODUCTS 120

TABLE 6.33 INTRACLASS CORRELATION COEFFICIENT OF DESIRABILITY VALUE OF NUMBER OF NEW PRODUCTS THAT ARE NEW TO THE WORLD.

TABLE 6.34 INTRACLASS CORRELATION COEFFICIENT OF DESIRABILITY VALUE OF NUMBER OF NEW PRODUCTS THAT ARE NEW TO THE COMPANY

TABLE 6.35 INTRACLASS CORRELATION COEFFICIENT OF DESIRABILITY VALUE OF NUMBER OF INNOVATION AWARDS 123

TABLE 6.36 INTRACLASS CORRELATION COEFFICIENT OF DESIRABILITY VALUE OF NUMBER OF INNOVATION AWARDS (EXCLUDING EXP1) 124

TABLE 6.37 DESIRABILITY VALUE - NUMBER OF INNOVATION AWARDS

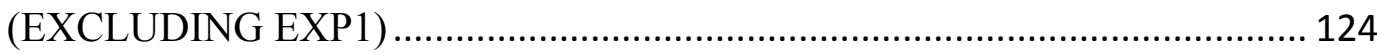


TABLE 6.38 INTRACLASS CORRELATION COEFFICIENT OF DESIRABILITY

VALUE OF NUMBER OF INNOVATION HONORS.

TABLE 6.39 INTRACLASS CORRELATION COEFFICIENT OF DESIRABILITY

VALUE OF NUMBER OF INNOVATION HONORS (EXCLUDING EXP1) 126

TABLE 6.40 DESIRABILITY VALUE - NUMBER OF INNOVATION HONORS

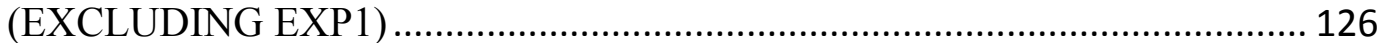

TABLE 6.41 INTRACLASS CORRELATION COEFFICIENT OF DESIRABILITY

VALUE OF NUMBER OF PATENTS FILED ............................................... 127

TABLE 6.42 INTRACLASS CORRELATION COEFFICIENT OF DESIRABILITY

VALUE OF NUMBER OF PATENTS GRANTED ........................................ 128

TABLE 6.43 INTRACLASS CORRELATION COEFFICIENT OF DESIRABILITY

VALUE OF NUMBER OF PATENTS CITED ……….................................. 129

TABLE 6.44 INTRACLASS CORRELATION COEFFICIENT OF DESIRABILITY

VALUE OF NUMBER OF PAPERS PUBLISHED ………............................ 130

TABLE 6.45 INTRACLASS CORRELATION COEFFICIENT OF DESIRABILITY

VALUE OF NUMBER OF PAPERS PUBLISHED (EXCLUDING EXP1) .... 131

TABLE 6. 46 DESIRABILITY VALUE - NUMBER OF PAPERS PUBLISHED (EXCLUDING EXP1)

TABLE 6.47 INTRACLASS CORRELATION COEFFICIENT OF DESIRABILITY

VALUE OF NUMBER OF PAPERS CITED .................................................. 132

TABLE 6.48 INTRACLASS CORRELATION COEFFICIENT OF DESIRABILITY

VALUE OF NUMBER OF PAPERS CITED (EXCLUDING EXP1)............... 133

TABLE 6.49 DESIRABILITY VALUE - NUMBER OF PAPERS CITED

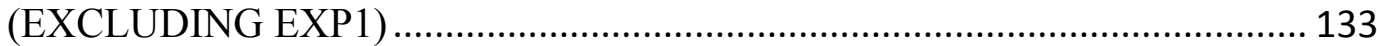

TABLE 6.50 INTRACLASS CORRELATION COEFFICIENT OF DESIRABILITY

VALUE OF NUMBER OF PAPERS PRESENTED …………….................... 134

TABLE 6.51 INTRACLASS CORRELATION COEFFICIENT OF DESIRABILITY

VALUE OF NUMBER OF PAPERS PRESENTED (EXCLUDE EXP1) …..... 135

TABLE 6.52 DESIRABILITY VALUE - NUMBER OF PAPERS PRESENTED

(EXCLUDING EXP1) ……………………………….......................... 135

TABLE 6.53 INTRACLASS CORRELATION COEFFICIENT OF DESIRABILITY

VALUE OF REVENUE FROM NEW PRODUCTS …………....................... 136

TABLE 6.54 INTRACLASS CORRELATION COEFFICIENT OF DESIRABILITY

VALUE OF MARKET SHARE OF NEW PRODUCTS .................................. 137

TABLE 6.55 ALLOWABLE RANGES OF PERTURBATIONS, TOLERANCE AND SENSITIVITY COEFFICIENT FOR OUTPUT INDICATORS TO MAINTAIN

REVENUE FROM NEW PRODUCTS AS THE TOP INDICATOR ................ 138

TABLE 6.56 RANKING OF OUTPUT INDICATORS FROM EXPERTS IN EXPERT

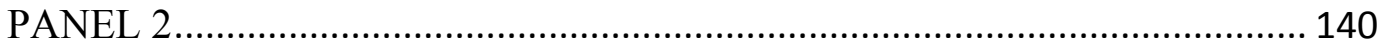

TABLE 6.57 RANKING OF OUTPUT INDICATORS ACCORDING TO DIFFERENT

SUB-GROUPS........................................................................................ 141

TABLE 6.58 PROFILE OF THE FIVE HYPOTHETICAL COMPANIES ................... 143 
TABLE 6.59 CHARACTERISTICS OF THE FIVE HYPOTHETICAL COMPANIES

TABLE 6.60 THE PERFORMANCE METRICS OF THE HYPOTHETICAL COMPANIES 144

TABLE 6.61 THE INNOVATIVENESS INDEX OF THE HYPOTHETICAL COMPANIES 145

TABLE 6.62 THE RELATIVE CONTRIBUTION OF SUB-FACTORS TO THE

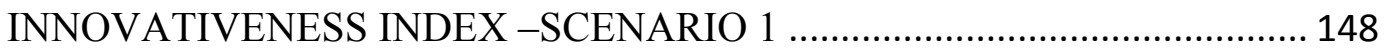

TABLE 6.63 THE INNOVATIVENESS INDEX OF HYPOTHETICAL COMPANIES -

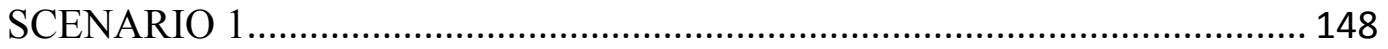

Table 6.64 THE RELATIVE CONTRIBUTION OF SUB-FACTORS TO THE INNOVATIVENESS INDEX - SCENARIO 2 149

Table 6. 65 THE INNOVATIVENESS INDEX OF HYPOTHETICAL COMPANIES SCENARIO 2 149

TABLE 6.66 THE RELATIVE CONTRIBUTION OF SUB-FACTORS TO THE INNOVATIVENESS INDEX - SCENARIO 3 150

TABLE 6.67 THE INNOVATIVENESS INDEX OF HYPOTHETICAL COMPANIES SCENARIO 3 151

TABLE 6.68 THE RELATIVE CONTRIBUTION OF SUB-FACTORS TO THE

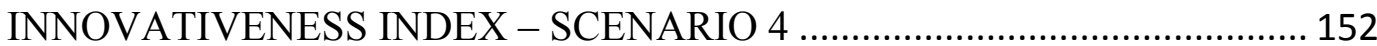

TABLE 6.69 THE INNOVATIVENESS INDEX OF HYPOTHETICAL COMPANIES SCENARIO 4 152

TABLE 6.70 COMPANY A WITH CHANGES IN PERFORMANCE METRICS -

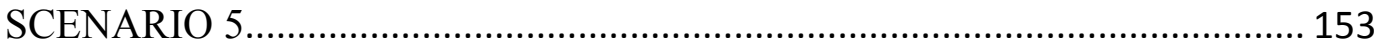

TABLE 6.71 COMPANY E WITH THE CHANGES IN PERFORMACE METRICS SCENARIO 6 155

TABLE 6.72 DESIRABILITY VALUE COMPANY D WITH THE CHANGES IN VALUES - SCENARIO 7 157

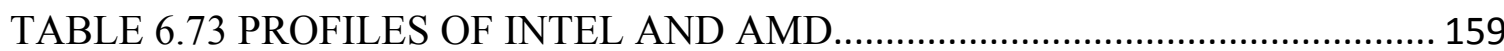

TABLE 6.74 THE PERFORMANCES METRICS OF INTEL AND AMD ................. 160

TABLE 6.75 THE INNOVATIVENESS INDEX OF INTEL AND AMD .................. 160

TABLE 7.1 FIRST CONTRIBUTION OF THE RESEARCH ................................... 167

TABLE 7.2 SECOND CONTRIBUTION OF THE RESEARCH .............................. 167

TABLE 7.3 THIRD CONTRIBUTION OF THE RESEARCH................................... 168 


\section{List of Figures}

Figure 3.1 Various shapes of desirability curves ........................................................ 51

Figure 5.1 Model of the Innovation Measurement ………......................................... 79

Figure 5.2 Data Collection Process............................................................................... 83

Figure 6.1 Number of experts who agree to include the output indicators in the

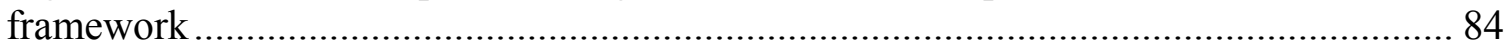

Figure 6.2 Relative Importance of the Output Indicators ............................................... 86

Figure 6.3 Relative Importance of Sub-Factors to Number of New Products.................. 87

Figure 6.4 Relative Importance of Sub-factors to Number of Innovation Awards .......... 87

Figure 6.5 Relative Importance of Sub-factors to Number of Patents.............................. 88

Figure 6.6 Relative Importance of Sub-factors to Number of Publications ..................... 89

Figure 6.7 The Desirability Value of Number of New Products New to the World ...... 121

Figure 6.8 The Desirability Value of Number of New Products New to the Company. 122

Figure 6.9 The Desirability Value of Number of Innovation Awards............................ 124

Figure 6.10 The Desirability Value of Number of Innovation Honors........................... 126

Figure 6.11 The Desirability Value of Number of Patents Filed.................................... 127

Figure 6.12 The Desirability Value of Number of Patents Granted .............................. 128

Figure 6.13 The Desirability Value of Number of Patents Cited ................................... 129

Figure 6.14 The Desirability Value of Number of Papers Published .............................. 131

Figure 6.15 The Desirability Value of Number of Papers Cited .................................... 133

Figure 6.16 The Desirability Value of Number of Papers Presented ............................ 135

Figure 6.17 The Desirability Value of Revenue from New Products............................. 136

Figure 6.18 The Desirability Value of Market Share from New Products ..................... 137

Figure 7.1 Research Streams, Primary Findings, and Research Gaps Identified from

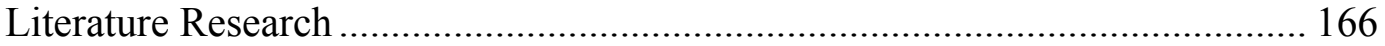

Figure 7.2 Contributions and Gaps of the Research .................................................. 169 


\section{CHAPTER 1: INTRODUCTION}

\subsection{BACKGROUND}

Adam Smith wrote, "It is the maxim of every prudent master of a family, never to attempt to make at home what it will cost him more to make than to buy. If a foreign country can supply us with a commodity cheaper than we ourselves can make it, better buy it of them with some part of the produce of our own industry, employed in a way in which we have some advantage" [1] .

That concept stimulates free trade in the global economy. Free trade is a system in which goods, capital and labor flow freely among nations without barriers which could hold back the trade process [1][2]. The free trade concept inspires many trade agreements that have been signed among nations, including the ASEAN Free Trade Area (AFTA) signed in 1992, Central European Free Trade Agreement (CEFTA) signed in 1992, and North American Free Trade Agreement (NAFTA) signed in 1994 [3][4][5].

The principle of free trade is that it will lower prices for goods and services by promoting competition [1]. Because of that principle, the competition has become more rigorous [2][6]. Free trade creates an environment in which companies in a particular nation need leverage and competitive advantages to be able to capture market share [6][1]. An innovative product or service is one leverage and competitive advantage for a company to become a market leader and stay ahead of its competitors [6]. The ability to produce new innovative products or services effectively and efficiently helps a company to compete in the global economy [1][2]. 
In 1997-2001 a major event occurred known as the DOTCOM crisis or DOTCOM bubble [7]. The economic downturn during that time created chaos in many areas including industries' innovation strategies and policies. Many companies tried to survive by cutting down costs [8]. One of the most obvious strategies in high-tech companies to survive that economic turmoil was downsizing and laying off employees. However, focusing exclusively on cutting down costs by downsizing has proven to be an unsuccessful strategy in the past. A significant number of companies were laying off staff without realizing that they were depriving themselves of the qualified workforce and core knowledge that would bring competitive advantages to the company [8].

In addition, some companies, especially those in the US, exercised the strategy of reducing their $R \& D$ budgets by moving the $R \& D$ activities to other countries with low labor costs such as India and China. In 2005, at an Asian business conference, Harvard Business School Professor Warren McFarlan stated, "Researchers in the U.S. may soon have as much to fear about losing their jobs to overseas competitors as call center employees do today" [9]. John Deng, CEO and President of Vimicro, supported McFarlan's statement. He pointed out that Vimicro is the proof of Chinese innovation. Currently, Vimicro holds approximately 400 patents as the world's leading supplier of PC camera processor chips. He said, "We have moved from 'manufactured in China' to 'designed in China"” [9]. Boeing, one of the world's largest aircraft manufacturers, also carried out the same strategy. Boeing was trying to reduce its costs by opening a Research and Technology - India Center in Bangalore in 2009, its third advanced research center outside the US [10]. 
The examples above show that innovation is shifting to Asia. U.S. companies will lose their competitive advantages if they do not manage their innovation activities accordingly. If the shift continues, it may be only a matter of time before the U.S. loses its status as the innovation center of the world.

It is important for companies to stay innovative to survive economic crises. Simply cutting down the workforce and moving R\&D to other countries does not solve the problem. However, having the right strategies would benefit companies and secure outstanding advantages. Intel's former Chairman Craig Barrett was a stellar example of a person who could comprehend and benefit from the circumstances. He stated, "You can't save your way out of a recession; you have to invest your way out" [11]. Instead of focusing on major layoffs or moving the R\&D activities during the late 1980s recession, he invested more in R\&D and tried to sustain Intel's workforce. His commitment to investment helped Intel to go through difficult times successfully. Unfortunately, not all companies share the same viewpoint. The majority of companies were still cutting down costs and moving their R\&D activities outside of the U.S., to places such as China and India, during the economic downturn.

In 2006, the European Commission formed the IMP ${ }^{3}$ rove Consortium project to develop, support, and achieve long-term improvements in innovation management, especially for small and midsize enterprises (SMEs) [12]. IMP ${ }^{3}$ rove Consortium confirmed that new products, services, processes, business models, or organization models can help companies to sustain and prolong profitable growth during an economic crisis [12]. IMP ${ }^{3}$ rove Consortium learned that only a company that has a systematic and results-oriented innovation platform will outperform its competitors. In addition, being 
innovative also helps a company to reduce "time-to-profit" [12] and provides an edge in being able to enter new markets faster and deeper. By incorporating innovation into the center of business, from top to bottom, a company can improve its financial numbers while discovering better ways of doing things that are more productive, more responsive, more inclusive, and even more fun [13].

The U.S. Department of Commerce realizes that innovation is the backbone of the economy to sustain competitive advantages, and that it is very important to be able to measure innovation. However, the US Department of Commerce also recognizes that the current measurements are inadequate. In September 2006, the U.S. Department of Commerce established an advisory committee on measuring innovation in the $21^{\text {st }}$ century economy. In January 2008 , this advisory committee came up with approaches to improve innovation measurement in the economy. It identified measures that need to be taken by the government, how the business community can help, and where research is needed [14]. The advisory committee acknowledged that there was a need to improve the innovation measurement by identifying more innovation indicators, especially innovation outputs.

Over a period of time, innovation — whether in products, services or business models - will become commoditized [15][16]. When innovation in a company becomes commoditized, the company will lose its competitive advantage. If a product becomes commoditized, only a company that sets the lowest price and has a global distribution network can survive [17]. However, it will not be a long survival since low prices produce small profits, and maintaining a global distribution network is costly. In order to gain competitive advantage, the company has to innovate in products, processes and 
services, or change the business to a different direction. Changing business direction is very risky. One of the many case studies of the last 25 years is Kodak in the digital camera market. Kodak was ranked no. 1 in the U.S. in digital camera sales, which surged $40 \%$ to $\$ 5.7$ billion in 2005 . Kodak was the leader in digital camera product innovation. It announced model after model offering consumers a variety of cameras with reasonable prices. However, Kodak did not anticipate how fast the digital cameras would become commodities. As new competitors aggressively joined the race, the profit margins became even lower. As a result, the success in product innovation did not result in comparable financial performance. Kodak was late to recognize the problem, slow to react, and then went down the wrong innovation path. It decided to focus more on business model innovations to reposition itself and shifted from hard products to digital services. Kodak aimed to provide new services and new ways to manage photos similar to what Apple does for music. It started to invest heavily in digital technologies, shutting down film factories and eliminating 27,000 jobs [15]. Shifting from hard products innovation to digital services innovation is a huge challenge, and history informs us that very few companies have done it successfully. Until now, it is far from clear how Kodak's story will play out.

The Kodak example demonstrates that innovation is critical as a source of competitive advantage. It has been shown that sustainable and profitable growth comes from new products, new services, new processes, new business models or new organizational models [12]. Because of the importance of innovation, companies are expected to be able to manage their innovation optimally. However, being innovative is not easy. A company needs to assess and measure its innovativeness in order to manage 
it. Having the capability to measure innovativeness gives a company good direction for how to increase its innovativeness.

Companies need a reliable framework for measuring their innovation. Having an innovation measurement framework helps them manage their innovation activities. Companies can track their innovation activities and review whether a learning loop is required to improve their innovativeness [18]. The measurement framework can also inform a company about which areas need improvement, and it helps the company make strategic decisions, such as where investments should be made and how resources should be allocated, especially to minimize risks during economic downturns.

This dissertation developed a framework, measurement processes, and metrics to measure the innovativeness of a company. The framework shows how innovative a company is compared to its peers and helps assist companies to better manage their innovation inputs in order to improve innovation outcomes.

\subsection{RESEARCH SCOPE, OBJECTIVE, APPROACH, OUTCOMES/ CONTRIBUTIONS AND APPLICATION}

As illustrated above, we see that innovation is critical for a company to sustain its competitive advantage. Because of this, a significant body of knowledge exists in research literature related to innovation. Existing research focuses on different areas of innovation. Examples include open innovation [19-22], innovation networks [23-26], diffusion of innovation [27-30], innovation clusters [31-34], user-centered innovation [35-37], and innovation intermediary [38-40]. This dissertation emphasizes innovation measurement. The ability to measure innovation is critical because one cannot manage 
without measurement [41][18]. Having metrics to measure innovation will help firms to optimize their investments in innovation [42].

The objective of this research is to investigate the topic of innovation measurement, and to develop a model as a measurement framework and metrics to measure the innovativeness for technological product innovation in technology-driven industries. The model identifies the innovativeness of a company based on output indicators. The results of the measurements provide insight into performance trends and identify the areas that need improvement in order to amplify the innovation activities in the future [43].

The hierarchical decision model (HDM) is used to create the measurement framework. HDM has been used to address many complex, real-world multi-criteria problems [44][45]. It organizes multiple factors into a hierarchy and facilitates the evaluations [46][47][48]. Innovation is complex and cannot be measured by a single factor. Because of the multiple factors and multiple impact relationships involved in innovation measurements, HDM is well suited for quantifying expert judgments such as the relative priority of the innovation outputs.

The result of this decision model/framework can help companies to identify their innovativeness based on output indicators. Measuring innovation based on output indicators eliminates biases in the results because there is no opportunity for the companies to compromise the results by incorporating input indicators that are controllable. The model calculates a numerical value as the measure of the innovativeness of a company. That value reveals how innovative a company is compared to its peers in the same context and provides insight into how the company may be able to 
improve its innovativeness by focusing on areas that need improvement. Companies can then track and review their innovation activities (inputs) and make changes that are most likely to improve their innovation outputs.

The application of the new measurement framework is illustrated by describing five hypothetical technology-driven companies that focus on product innovation. 


\section{CHAPTER 2: LITERATURE REVIEW}

\section{$2.1 \quad$ INTRODUCTION}

The expression "innovate or die" has been an accepted phrase in the popular business environment [49]. Innovation is considered one of the most important business drivers for companies' growth and is also one of the important sources and enabler of competitive advantage [50][51][52][53]. Joseph Schumpter is believed to be the first economist who drew attention to the importance of innovation [54]

There are several definitions of innovation. According to Schumpeter [55], "Innovation is the commercial or industrial application of something new - a new product, process or method of production; a new market or sources of supply; a new form of commercial business or financial organization." The Organization for Economic Cooperation and Development (OECD) has a more comprehensive definition: "An innovation is the implementation of a new or significantly improved product (good or service), or process, a new marketing method, or a new organizational method in business practices, workplace organization or external relations. Innovation activities are all scientific, technological, organizational, financial and commercial steps which actually, or are intended to, lead to the implementation of innovations" [56].

According to the European Commission, "Innovation covers a wide range of activities to improve firm performance, including the implementation of a new or significantly improved product, service, distribution process, manufacturing process, marketing method or organization method"[57]. The Department of Commerce has a definition of innovation in which, "The design, invention, development and/or 
implementation of new or altered products, services, processes, systems, organizational, models for the purpose of creating new value for customers and financial returns for the firm" [14]. ASTRA, through its "Innovation Vital Signs" project, also has a definition: "Innovation success is the degree to which value is created for customers through enterprises that transform new knowledge and technologies into profitable products and services for national and global markets. A high rate of innovation in turn contributes to more market creation, economic growth, job creation, wealth and a higher standard of living"[58]. The Council on Competitiveness defines innovation as, "the intersection of invention and insight, leading to the creation of social and economic value"[59]. L. Morris [18] states, "The method of innovation is to develop ideas, refine them into a useful form, and bring them to fruition in the market where they will hopefully achieve profitable sales or in the operation of the business where they will achieve increased efficiencies." Even though different scholars give different definitions for innovation, the core of innovation is creating something that did not previously exist and taking it all the way to commercialization. Innovation definitely creates business value [18]. The value manifests itself in different forms, e.g., there could be value from radical innovation leading to entirely new products, as well as from incremental innovation leading to improvement in existing products.

Innovation is important because in this knowledge era, many companies see it as a strong contributor and means for generating business and profitable growth that will improve an organization's performance and competitiveness [60]. Sustainable and profitable growth in a company requires sustainable innovation activities [43]. Before the current product or service reaches the maturity level or technological obsolescence (flat 
level on the top of the S curve), companies have to come up with a new business opportunity, an improved product line or service, to maintain growth and to stay ahead of competitors. Innovation will help to fuel the growth of new products or services, sustain incumbents, create new markets, transform industry, and promote the global competitiveness of nations [61] [62] [14] [63][64]. History has proven that only companies that innovate will survive, and companies that do not innovate will likely not survive let alone compete in the rapidly changing market [18].

In a broader view such as for a region or a nation, innovativeness can enhance public understanding and help policymakers to improve their policies and strategies and therefore can also be used to attract investors [65].

There are several types of innovation [66]:

- Product Innovation: introduction of new or improved goods or services in terms of technical specifications, user friendliness, components, materials, or other functional characteristics.

- Process Innovation: introduction of a new process which consists of significant improvements in techniques, equipment, etc. Usually it relates closely to production or delivery methods.

- Marketing Innovation: introduction of new methods in the marketing area. The innovation mostly will happen in the pricing, distribution channel, product promotion, product placement, etc. 
- Organizational innovation: introduction of a new organizational technique on how work can be organized. The innovations usually take place in practices, workplace organization or relationships with external parties.

Kingsland categorizes innovation according to the degree of novelty. The categories are [67]:

- Incremental Innovation: usually smaller, easier to implement and less risky. The timeline is also shorter and associated with many projects within the organization.

- Breakthrough (radical) Innovation: usually bigger, more complicated to implement and high risk. The timeline will be longer and associated with few projects within the organization. If it delivers well, it will disrupt the market and provide a big leap in growth.

For many years companies have relied on innovation as a motor to stimulate the growth and sustainability in their business [50][51][52][53]. Innovation helps companies to prolong the development of new products or services for new business opportunities. Without the creation of new products or services, companies will find it difficult to maintain growth and stay in front of their competitors [53].

Because of its importance, companies need to manage innovation. If it is not managed, it will be a great challenge for companies to maintain their competitive advantage and sustain their operations. The economic success of companies depends on the innovativeness of their products and services [63][64]. Before companies can take 
action to manage their innovation activities, they need to identify their innovation capabilities. It is important for companies to be able to measure their innovativeness because you cannot manage what you do not measure [18] [41]. By measuring their innovation capabilities, companies will be able to realign their business strategy [68] [42]. If the measurement is done appropriately, it will help the companies to understand their current position and to identify areas that need improvement to amplify the innovation activities in the future [43].

\subsection{INNOVATION MEASUREMENT}

Measuring innovation has attracted many researchers, who have conducted studies to measure innovation by using different methodologies and indicators. Some measure innovation based on a single indicator, while others focus on several indicators. In addition to indicators, innovation indexes also have been proposed to measure innovation, but the innovation indexes in the literature are typically used for measuring innovation at the national level includes environmental, social, and political variables in the measurement. The literature research in innovation measurement can be divided into three research streams,

\subsubsection{Input and output as foci of innovation measurement.}

The literature search shows that many companies measure their innovation by considering a combination of input and output indicators. The focus of the most of the research is on specific areas such as high-tech industry, service industry, private and 
public sectors, knowledge-based firms, forest industry, pharmaceutical firms and eLearning.

L. Potters [60] looks into innovation input and output as the indicators of innovativeness. Mainly, the research investigates the impact of innovation activities on innovation output. The data are collected from Spanish CIS 3 data of 3,247 firms. Potters performs correlation analysis and concludes that different innovation activities and different innovation behaviors exist across sectors.

Milbergs and Vonortas [65] urge researchers to do a better job in measuring innovation. They categorize science, technology and innovation (STI) indicators in four categories (input, output, innovation, and process), and they give benefit-cost recommendations.

The Michigan Department of Labor \& Economic Growth [69] produces an annual report regarding innovation indicators. The report lists several indicators which later are used to measure Michigan's strengths and weaknesses related to innovation in the economy.

The Advisory Committee on Measuring Innovation in the 21st Century Economy has published a report regarding innovation measurement [14] and submitted it to the US secretary of commerce. The report states that many of the innovation measurements are focused on inputs, and only a few are focused on outputs. The committee urges the need for having research that focuses on innovation outcome measures. The current state of measurements is recognized as being inadequate. They conclude that there is a need to improve the innovation measurement by identifying more innovation indicators, especially innovation outcomes. 
Arundel and Hollanders [70] identify new indicators based on the European Community Innovation Surveys (CIS) for measuring national innovative capabilities. These new indicators can assist European Union policy makers in developing national innovation policies.

Vega-Jurado et al. [71] analyze the effect of internal and external factors on product innovation. They analyze the survey results from 6,094 Spanish manufacturing firms and identify that the main determinant of product innovation is the firm's technology competence. Their findings have had an important role in designing Spain's innovation policy.

Griffith et al. [72] investigate the relationship between innovation and productivity at the firm level in four European countries (France, Germany, Spain, and the UK). They apply data from the third Community Innovation Survey (CIS 3) to a model that incorporates links among R\&D expenditure, innovation output and productivity. They find that the results of different innovation output measurements are determined by the innovation effort.

B. Godin [73] focuses on innovation output indicators to measure innovation as explored by the OECD. Godin discovers the importance and significance of using output indicators for innovation measurements compared to input indicators. Godin also finds that measuring innovation by using output has been gaining more attention after the OECD developed three output indicators: indicator on patent, indicator on the technological balance of payment (TBP), and indicator on high technology trade.

Gold, in her paper "The Impact of Technological Innovation - Concepts and Measurement" [74], emphasizes that the past studies about innovation measurements are 
inadequate. There is a need for a deeper and more comprehensive framework to analyze innovation by relating inputs and outputs.

B.L. Basberg conducts a literature review on patents and measurements of technological change [75]. In his paper, Basberg emphasizes the use of patent data as a source of information for measuring technological change. The author believes that patent data have limitations in measuring technological innovation and recommends that patent data should be used cautiously to learn something from it.

\subsubsection{Metrics and methodologies for measuring innovation.}

The second research stream focuses on the metrics and methodologies to measure innovativeness. Numerous studies have been conducted to measure innovation of a firm, each one using different metrics and methodologies.

L. Morris [18] explores the measurement by introducing an innovation funnel. According to Morris, innovation has nine steps (strategic thinking, portfolio management and metrics, research, ideation, insight, targeting, innovation development, market development, and sales). In each step, Morris lists possible metrics by asking questions from qualitative and quantitative perspectives.

I. Pallister (managing director of Innovaro Strategies in Europe) [41] identifies metrics for measurement and categorizes them into corporate metrics and business metrics in his report. Pallister also stresses that different sectors might have different measurement mechanisms and highlights the importance of attaching the input indicators to the output indicators. 
P. Gupta [43] contends that the current state of measurement is not adequate. Most of the measurements do not succeed in extracting information from the output measurements. Gupta proposes a model called SIPOC (supplier, input, process, output and customer) to analyze the innovation process.

Spectrum Innovation Group [67] proposes a new innovation measurement to the U.S. Department of Commerce. They use survey methodology to obtain the data. The measurements start with small firms as the aggregate activities of those small firms are actually the main component of the economy. The proposed approach suggests measuring the activity from the root by differentiating innovative and non-innovative firms, innovation and non-innovation activities, and identifying specific data of the firms that relate to innovation for aggregation.

Cordero [68] creates a model using outputs and resource indicators to evaluate the overall performance of a firm. He measures every stage of the innovation process such as the planning stage, control stage, technical stage and commercialization stage. The results show that the most frequently used indicators are quality of technical output, degree of goal attainment, and amount of work done on time.

McKinsey Global [76] conducts a survey to see how companies measure their innovation. Senior executives are the subject of the research. The surveys uncover types of innovation in those companies, what things are being measured, what kinds of metrics are used, what they want to achieve with the measurements, and how satisfied they are with the current measurements. From the survey, McKinsey finds that companies which conduct more comprehensive measurements are those that get the highest returns from 
innovation. In addition, measurements also help companies to align individual performance, innovation performance and communication with investors.

Archibugi and G. Sirilli [77] introduce two approaches to measure technological innovation. The first approach is the subjective approach, which usually involves surveys and interviews in a particular firm. Quantitative and qualitative questions are provided for the firms to collect the information that later is used to find the innovation level of the firms. The second approach is the objective approach based on innovation counts. Instead of analyzing the firm itself, the objective approach analyzes the technological innovation using expert surveys, bibliometrics, new product announcements, etc.

S. Rose et al. [78] propose two alternative frameworks for innovation measurements. The first framework focuses on measuring activities at the firm level. The second framework looks at investments that enable a firm to conduct innovation activities.

Moos et al. [79] review 56 articles from 12 major journals to compare the measurement models. They find that there are many concepts in measuring innovativeness; however, the concepts are inconsistent. The authors point out that those innovation measurements can be distinguished into input and output orientations.

Wei and Xiaobin [80] develop a model to incorporate explorative and exploitative learning, product innovativeness for firm and customer, and objective and subjective quality. They conduct a study from the existing research and theoretical deduction and uncover that organizational learning has a positive impact on improving product innovativeness. 
Evangelista et al. [81] use a Community Innovation Survey (CIS) to measure the regional innovation process. They come up with multi-dimensional indicators from firms' strategy, firms' performance, system performance and industrial structure. They find critical methodological issues when using CIS data at the regional level.

Jensen and Webster [82] use survey methodology to examine biases in various innovation measurements. They conclude that there is no significant correlation between self-reported measures and accounting or administrative measures.

$\mathrm{Xu}$ et al. [83] use the total innovation capacity (TIC) index system to validate the innovation performance of Chinese firms. The TIC index is based on the innovation elements of the total innovation management (TIM) framework that was initially introduced by Zhejiang University Research Center for Innovation \& Development in 2002.

A.M. Aizcorbe et al. [84] measure innovation for the Bureau of Economic Analysis (BEA) mainly focusing on R\&D accounts as indicators of innovation activity. The authors incorporate intangible assets for better measurements.

Most of the measurements for the $R \& D$ performance are focused on $R \& D$, knowledge, and/or performance management, and each measurement is independently designed. Choi \& Ko [85] propose an integrated innovation metric which can measure all innovation activities for R\&D innovation and investigate the impact of innovation. The metric consists of four R\&D innovation metric groups by considering firms' innovation ranges and some common issues of innovation. This metric is called an integrated innovation metric since it can measure all R\&D innovation activities. 
A series of papers from Liu et al. [85], [86] measures organizational innovation in Taiwanese high-tech enterprises by using literature review, in-depth interviews, and small group techniques as bases for construction of an organizational innovation measurement model.

Guan and Chen [88] construct an innovation production process (IPP) framework that covers the upstream R\&D process and downstream commercialization process. They carry out an empirical study of China's high-tech companies and find that the output (commercialization) is an important stage and has closer correlation with IPP performance.

Huang and Lin [89] conduct literature review and case studies and then develop a framework to study the interaction among innovation indicators of R\&D team innovative performance measurements. They also use a survey of high-tech industries in Taiwan to justify the framework.

Zheng et al. [90] develop an innovation performance audit system based on measurements. They create a framework of key performance indicators and then collect data from high-tech industries to test and validate their framework.

Adams et al. [91] use literature review to measure innovation management at the firm level. Their research contribution is a single framework that can be used by managers to review their companies' innovativeness.

Heras and Dröge [92] conduct a follow-on research study to see whether Adams et al.'s framework [91] can be applied in service innovation management. They conduct a case study in the hospitality industry and find that although there is a high correlation in 
performance measurements, some indicators, such as patents, cannot be used in the service industry.

E.G. Carayannis produces a report for innovation vital signs in regard to identifying past, present, and emerging innovation metrics and indicators from public and private sector perspectives [93]. Carayannis agrees with several researchers who state that measurements should have more than one indicator, as that would help reduce the noise and provide better measurements [93-95]. Carayannis also emphasizes that the data needed for measurement purposes should be available, built on time series, and allow for the desired level of granularity.

Hipp and H. Grupp [96] investigate the methodology to measure service innovation in Germany by adapting existing measurement concepts derived from the manufacturing industry. They use a survey in their study. The survey shows that the measurement concepts from manufacturing industries fit some of the service innovations that demonstrate the classical innovation structure.

Blomqvist et al. [97] view the challenges of innovation measurements in knowledge-based firms from a managerial point of view and present a case study of a large telecommunications industry. The authors point out the importance of adding the outcome metrics to the performance measurement system.

McAdam and Keogh [98] explore the transition from traditional measures to creativity and innovation measures in SMEs. There are two suggestions from the authors. First, measuring creativity and innovation needs to have more operational and strategic importance. Second, because of the diversity within creativity and innovation, a more flexible range of measures needs to be used. 
D.P. Wang and K. Dickson [99] use questionnaires to measure technological innovation of small- and medium-sized manufacturing enterprises in China. The questionnaires refer to the Oslo Manual, a quantitative approach in which the results of the questionnaires are used to construct an index system which is later calculated by using a mathematical model. The results show that small- and medium-sized manufacturing enterprises in China are relatively weak compared to other countries, referring to the input, intensity and outcome measures.

Hansen et al. [100] interviewed forest industry managers to explore the concept of innovativeness from their perspective and to identify innovation factors to improve.

L. Crosta and V. Prieto study the innovation measurements in eLearning [101]. The focus of this study is on technological innovation, sociological innovation and service customization in eLearning projects. The challenge pointed out by the authors is in transforming the indicators into a numerical score. They conduct a survey through questionnaires. The authors utilize the scoring model for measuring innovation in eLearning.

Subramaniam and Youndt [102] focus on the influence of intellectual capital in firm innovativeness. They gather data from questionnaires and surveys, analyze it, and conclude that although human capital that interacts with social capital has a positive impact on radical innovative capability, human capital by itself has a negative influence on radical innovative capability. They also find that social capital has a significant positive influence on both incremental and radical innovative capabilities.

A National Research Council report [103] for a workshop on innovation indicators lists patent counts and citations as ways to measure innovation. It also 
recommends new measures of innovation output that focus on financial market valuations, innovation counts and bibliometrics.

Jensen and Webster [104] examine the relationship among different innovation proxies across different industrial sectors and find that their proxies are strong indicators only in product innovation/manufacturing. They also find that different proxies might have substantially different results, so it is necessary to be careful when selecting the measurement proxies. Finally, they conclude that there is a strong correlation among R\&D indicators, patents and trademarks in service sector firms.

Mairesse and Mohnen [105] explore the importance of R\&D for the innovation process using data from the third Community Innovation Survey (CIS 3). They use econometric modeling to test the data and conclude that R\&D has a positive correlation with all measures of innovation output. They also find that, in general, innovation is more sensitive to R\&D in low-tech industries compared to high-tech industries.

Vermeulen et al. [106] test a conversion model to measure the innovativeness of small and medium manufacturing and service firms (SMEs) in the Netherlands. They conclude that if the model is extended with contextual variables, type of industry and firm size, it shows that there is a relationship between innovation output and financial performance in larger firms.

F.I. Ortiz et al. [107] propose a measurement system for technological innovation of products and processes. They use sets of indicators identified by the experts to define a measurement system. The system is comprised of instruments, procedures, and methodologies to analyze the capacity of innovation, thus making it possible to do a comparison among companies. 
Lööf and Heshmati [108] conduct econometric studies in Swedish manufacturing companies. They review existing econometric methods, then propose a new model and apply it to a unique data set. Their focus is on the relationship between innovation and productivity growth among firms. The results show that although the innovation process has uncertainties, the firms' level of innovation output rises significantly with innovation efforts.

Velásquez et al. [109] propose a methodological tool to identify and classify the indicators that are required to assess and measure technological innovation capabilities. A survey is conducted with 108 managers of the biggest German industrial markets. The relationship of customer orientation, new product performance and company size are also investigated. The results show there is no significant relationship among those elements in small- and medium-sized enterprises (SMEs). On the other hand, in big companies there is a highly significant correlation among those elements.

Godin conducts a follow-up study on the rise of innovation surveys to measure the fuzzy concept [110]. Godin investigates methodologies used in measuring innovation and states the need for developing output indicators. He observes that the early official measurements were using input indicators, and recently innovation measurements are being focused on outputs. The methodology that he uses is mostly surveys. In conclusion, Godin finds that the use of output indicators is the better approach and is becoming the standard approach.

R. Coombs et al. [111] propose the literature-based innovation output indicators (LBIOI) methodology. They utilize the new product announcements in trade and technical journals as indicators of innovation activities. They suggest that literature-based 
innovation output indicators should be used as a compliment to the existing indicators. The finding indicates that the method is useful to measure the degree of radicalness of innovations. The method works better for measuring product innovation than process innovation. Walker et al. [112] show that the LBIOI method can also be applied to public service organizations.

T. Clayton et al. [113] look for a way to measure innovation processes at all stages. There are two main measurement areas: upstream (R\&D) and downstream (marketing and organizational). The authors propose that research should concentrate more on the outputs in measuring innovation.

B. Glasmann [114] identifies a common set of outputs for innovation measurements and concludes that there is no general or common metric to measure innovation that can be used across industries. Therefore, Glassman utilizes subjective measures and makes suggestions about how to select metrics according to the companies' needs.

Maeno et al. [115] compare three different databases (patents, published papers, and newspaper articles) and conclude that the number of patents is a more appropriate way to gauge trends in technology innovation products than the number of papers or newspaper articles. This research looks at inkjet printers, laser printers, pagers and mobile phones as the examples.

Through patent analysis, Ken et al. [116] measure the technology innovation capabilities of game software industries. This study is based on a general approved patent indicator and takes patent application, gain and the location of publication as 
considerations. The analysis results demonstrate that the gaming industry still has considerable potential for further investment in innovative R\&D.

Table 2.1 below summarizes the methodologies being used to measure innovativeness by scholars and practitioners.

TABLE 2.1 METHODOLOGIES IN INNOVATION MEASUREMENT FROM LITERATURE RESEARCH

\begin{tabular}{|l|l|}
\hline \multicolumn{1}{|c|}{ Methodology } & \multicolumn{1}{c|}{ References } \\
\hline Literature review & {$[46][78][79][89][95][97][75]$} \\
\hline Interviews & {$[117][118][46][78][106][119][100][99][107][120][121]$} \\
\hline Factor analysis & {$[117][122]$} \\
\hline Cluster analysis & {$[123]$} \\
\hline AHP & {$[117][124][125][126][127][128]$} \\
\hline Survey & {$[129][118][67][76][130][18][110][67][131][96][104][12$} \\
& $3][102][122][71][132][90][125]$ \\
\hline $\begin{array}{l}\text { Literature-based innovation output } \\
\text { method }\end{array}$ & {$[119][77][133][99][120][70][121]$} \\
\hline $\begin{array}{l}\text { Knowledge Production Functions } \\
\text { (math function) }\end{array}$ & {$[111][131][120][134][112]$} \\
\hline $\begin{array}{l}\text { Event Study Method (efficient market } \\
\text { hypothesis) }\end{array}$ & {$[61]$} \\
\hline Pair-Wise Correlations analysis & {$[104]$} \\
\hline $\begin{array}{l}\text { Some company/organization } \\
\text { database/reports/publications }\end{array}$ & {$[106][135][123][136][95][107][137][138][139][140]$} \\
\hline $\begin{array}{l}\text { Group storytelling (kind of group } \\
\text { interviews)/ focus group }\end{array}$ & {$[53][97][117][129][46]$} \\
\hline Quasi field experiment (simulation) & {$[141]$} \\
\hline Case study & {$[89][97][142]$} \\
\hline Delphi method & {$[126]$} \\
\hline DEA & {$[88]$} \\
\hline $\begin{array}{l}\text { Not applicable } \\
\text { (12) }\end{array}$ & {$[143][41][144][43][74][80][145][146][147][148][84][73$} \\
\hline
\end{tabular}




\subsubsection{Used of multi-dimensional approaches to measure multi-attributes of innovation}

The third research stream focuses on the use of multi-dimensional approaches to measure innovation by looking at multiple attributes.

Liu et al. [46], measure innovation by using an index weight. The weighted measurement index is derived from objective and subjective data. The results conclude that product innovation, process innovation and strategic innovation are the most important dimensions respectively in organizational innovation.

Sood and Tellis [61] assess the innovation returns in their paper. They find that markets react more to the development phase of the innovation than the commercialization phase. So companies have to exploit the development progress in their announcements to gain more attention of the market. They consider multiple-attributes of the innovation in their study.

Innovation Vital Signs-Astra project [144] identifies candidate indicators for measuring innovation in the report for the U.S. Department of Commerce's Technology Administration. Several indicators are identified under input factors, process factors, outcome factors and context factors. The majority of the indicators are derived from the literature.

Subramanian [150] states that in measuring innovativeness, a time period to capture early adopters needs to be specified. He also tests and validates that innovativeness is a multidimensional construct. He finds that if unidimensional measures are used, the complex relationships of the indicators might not be detected.

Salomo et al. [151] propose a multidimensional concept of innovation field orientation. This orientation is comprised of the setup and management of multiple 
related NPD projects. An innovation field has the ability to stimulate the synergy of those related projects. An innovation field contains different aspects such as customer need, customer group, technology, and core competence. They conduct an empirical study by collecting data with a survey and document analysis. They conclude that only those firms which manage innovation fields are more successful and have more innovative product portfolios.

Chen et al. [124] evaluate technological innovation capabilities by addressing three main issues: construction and filtration of the evaluation system; determination of the evaluation index system weight; and the selection of a comprehensive evaluation method. In this study AHP is used to determine the evaluation index system weight. The factors not only included input and output indicators, but also corporate's culture. The authors use state-owned enterprises in the Chinese Northeast Industrial Base. Even though it is restricted to northeast region, it shows that this method is feasible.

Ying et al. [128] use AHP to define a service innovation performance evaluation (SIPE) index and apply it to measure innovation performance of a telecommunications company in China. The study is limited to service innovation which focuses on customer satisfaction, value of service innovation, quality or service, ability of new service, learning ability of organizations, learning ability of employees, and marketing ability as the indicators.

Rothaermel and Hess [137] develop a multilevel theoretical model to evaluate innovativeness on three different levels: individual level, firm level, and network level. They collect data from pharmaceutical firms and organize the data according to a dependent variable (innovative output), independent variables (intellectual human capital, 
R\&D capability, etc.), and controlled variables (patents, firm size, etc.). This research emphasizes that intellectual human capital counts toward a firm's innovativeness.

S.G. Green et al. [152] explain the development of measures for innovation radicalness that utilizes a multi-dimensional concept. Methodologies used in their paper are reliability analysis, and both exploratory factor analysis and confirmatory factor analysis. The main purpose of the paper is to develop a multidimensional measure of radical innovation. The authors conclude that the amount of technological uncertainty of the project can measure the radicalness of the innovation effort.

M. G. Quinn [133] identifies elements for setting up headline indicators in innovation to support the Europe 2020 strategy. Quinn lists a set of properties that need to be referred to in order to create desirable indicators. Later on, Quinn identifies several indicators such as patents and labor productivity and benchmarks them for the European Union in relation to the US, Japan and South Korea.

J. Mote et al. investigate how to measure radical innovation in real time [119]. The authors collaborate with two research organizations, and during the collaboration the real-time indicators are developed. The finding implies that multiple measures on multiple attributes provide more accurate results.

Shapiro [142] points out that it is difficult to determine innovativeness with a single measure. He suggests using "fixed" and "variable" measures in pairs to be more effective. According to him, the most common measure that most companies use is "percent of revenue from new products." In his 25 years of innovation-oriented consulting, he cannot recall any single company that does not implement that measure at some point. However, since using only a "fixed" measure is not enough, the author 
proposes combining the revenue from new products and from new platforms. Revenue from new products focuses on the products and gives a description of the overall rate of change, while revenue from new platforms focuses on several attributes such as technology, product, manufacturing, etc., and reveals the degree of newness. By combining these measures, the author believes that companies will be better at measuring their level of innovativeness.

\subsection{WHY OUTPUT INDICATORS}

This research is focused on output indicators because outputs are uncontrollable and unpredictable [78], while inputs and processes can be managed and controlled by the company. Measuring something that can be controlled and managed from within the firm biases the results. For example, a company can increase the R\&D expenditures as high as it wants; however, that increase does not necessarily assure that the company is highly innovative. Simply having high inputs may or may not produce high outputs. The innovativeness of a company is based on outputs of the innovation activities. Inputs define the scope, context and structure of innovation. Inputs do not show the economic significance of the innovation output [131]. Outputs transform innovation activities into economic value for the company [18].

Several scholars agree and support the use of output indicators to measure innovation. Kleinknecht and Bain [153] support the idea of measuring innovation by using a literature-based methodology. They point out that counting output indicators will facilitate international comparisons. Output indicators are also more viable because the data for outputs (number of new products, patents, publications, etc.) are available and 
thus verifiable. They can be objectively measured without creating unnecessary bias. Steward [131] agrees with Kleinknecht and Bain. Steward points out that the majority of innovation outputs are available to the public in some form. Because of their visibility, innovation outputs can be used for the development of useful indicators. Input indicators such as $R \& D$ expenditures will not be effective because obtaining such data from companies is not straightforward. Usually, input indicators are covered by accounting procedures [131]. Steward adds that measuring outputs uncovers the contributions of small firms. Output indicators show great potential for establishing innovation indicators that are internationally comparable and can be implemented and revisited on an annual basis.

Vermeulen et al. [106] also measure innovation based on output indicators. One of their findings indicates that innovation outputs correlate to a firm's performance.

Link [143] lists the advantages of measuring output, for example:

- $\quad$ Appropriate: Output indicators are countable and can be evaluated at any given time.

- Complete: Output indicators perform as a market test for the success of the innovation process.

- $\quad$ Replicable: Output indicators are replicable and are from verifiable sources.

The National Science Foundation (NSF) also shows that measuring innovation based on output indicators is appropriate. The NSF was the first government organization 
to measure innovation based on output indicators by counting commercialized technological innovations [110].

Coombs et al. [111] use a more direct innovation output measurement in a national economy. They measure innovation by counting new product announcements in trade and technical journals.

In addition, Moos et al. [79] support output-oriented measurement, especially for innovation that comes from within the firms.

Huong et al. [154] measure innovation at the regional level. The outputs of innovation at the regional level can be direct and indirect. The authors point out that innovation output is an important aspect in measuring technology innovation capability. Santarelli [134] agrees with Huong et al., stating that innovation output indicators are the most reliable means to capture the economic value and significance of innovation activities.

If the output measurements are done right, a company can track innovation activities (input) and review whether there is a learning loop needed to improve innovation outputs [18].

\subsection{OUTPUT INDICATORS FOR INNOVATION MEASUREMENT}

A large number of output indicators has been identified in the literature. Scholars and practitioners have been using different output indicators for innovation. The most common output indicator is the number of new products. Scholars and practitioners mostly use the number of new products that are released to the market by a company as an innovation indicator. However, different authors use different metrics for it. Some 
look at new products in general, some look at the number of new products over a certain time period, some look at the number of new products that lead industry, etc. Another common output indicator that is often used by scholars and practitioners is the number of patents. Some look at the number of patents filed by the company over a certain period of time, while others look at the number of patents being granted. Still others look at the number of patents from a company being cited to determine the quality of the patents. Revenue generated from new products is also a popular output indicator used by scholars and practitioners. It is believed that the more revenue generated from new products, the more successful the innovation is. Bibliometrics such as scientific publications are also used as an innovation output indicator. Some scholars introduce LBIOI as a method to measure innovation based on the announcement of new products from technical or trade journals. Similar to patents, the number of citations from scientific publications is also used to determine the quality of the publications from the company. Sales of new products are also considered as a common innovation output indicator. It can be sales of new products from incremental innovation or radical innovation. Table 2.2 below summarizes output indicators gathered from literature research that are commonly used in innovation measurements. 
TABLE 2.2 OUTPUT INDICATORS FROM LITERATURE RESEARCH

\begin{tabular}{|c|c|c|c|}
\hline $\begin{array}{c}\text { Output } \\
\text { Indicators }\end{array}$ & Descriptors & References & Description \\
\hline \multirow[t]{5}{*}{$\begin{array}{l}\text { \# of new } \\
\text { products }\end{array}$} & & $\begin{array}{l}{[46][41][144][43][76][130][1} \\
8][111][74][110][67][131][6 \\
0][61][96][78][95][104][80][ \\
106][135][53][123][102][141 \\
][122][136][79][71][89][129] \\
{[117][154][124][132]}\end{array}$ & $\begin{array}{l}\text { Total number of new products } \\
\text { that are released to the market } \\
\text { by a company }\end{array}$ \\
\hline & $\begin{array}{l}\text { In a certain time } \\
\text { period }\end{array}$ & {$[117][118]$} & $\begin{array}{l}\text { Total number of new products } \\
\text { that are released to the market } \\
\text { by a company in a certain } \\
\text { period of time }\end{array}$ \\
\hline & That lead industry & {$[117][122][79][71][89]$} & $\begin{array}{l}\text { Total number of new products } \\
\text { that are released by a company } \\
\text { and lead the market }\end{array}$ \\
\hline & $\begin{array}{l}\text { Ratio of new } \\
\text { technology applied in } \\
\text { new products }\end{array}$ & {$[125][90]$} & $\begin{array}{l}\text { Number of new technologies } \\
\text { that are applied to new } \\
\text { products }\end{array}$ \\
\hline & $\begin{array}{l}\text { Degree of commercial/ } \\
\text { product success }\end{array}$ & [119] [100][129] & $\begin{array}{l}\text { The success degree of new } \\
\text { products by a company }\end{array}$ \\
\hline \multirow[t]{2}{*}{$\begin{array}{l}\text { Awards and } \\
\text { Honors }\end{array}$} & & {$[119][61][103][126][97]$} & $\begin{array}{l}\text { Awards and honors can be } \\
\text { used to confirm the successful } \\
\text { achievements of a company }\end{array}$ \\
\hline & In product innovation & [117] & $\begin{array}{l}\text { To be specific, the } \\
\text { achievement of certain } \\
\text { innovation product. }\end{array}$ \\
\hline $\begin{array}{l}\text { On time } \\
\text { delivery/ } \\
\text { Time to market }\end{array}$ & & {$[117][41][144][18][129]$} & $\begin{array}{l}\text { Total number of time } \\
\text { (day/month/year) from } \\
\text { research through to sales }\end{array}$ \\
\hline \multirow[t]{4}{*}{ \# of Patent } & & $\begin{array}{l}{[41][144][84][43][73][130][1} \\
8][143][111][110][67][131][ \\
60][93][77][133][75][99][11 \\
9][61][103][107][96][78][10 \\
0][120][88][106][137][89][1 \\
29][138][126][154][95][139] \\
{[134][90]}\end{array}$ & $\begin{array}{l}\text { Total number of patents are } \\
\text { filed or granted in a certain } \\
\text { period of time. }\end{array}$ \\
\hline & Patent filed & {$[46][70][79][125]$} & $\begin{array}{l}\text { Total number of patents filed } \\
\text { in a certain period of time }\end{array}$ \\
\hline & Patent grants & {$[70][79][124][125][140][69]$} & $\begin{array}{l}\text { Total number of patents } \\
\text { granted in a certain period of } \\
\text { time }\end{array}$ \\
\hline & $\begin{array}{l}\text { Number of patent } \\
\text { citations }\end{array}$ & {$[120][89][95]$} & $\begin{array}{l}\text { Total number of patent being } \\
\text { cited }\end{array}$ \\
\hline
\end{tabular}




\begin{tabular}{|c|c|c|c|}
\hline \multirow[t]{6}{*}{ Revenue } & & {$[129][125][140]$} & $\begin{array}{l}\text { Revenue received based on } \\
\text { product of technology } \\
\text { innovation for certain period } \\
\text { of time }\end{array}$ \\
\hline & Growth & {$[41][43][100][118][125][90]$} & $\begin{array}{l}\text { Percent of company revenue } \\
\text { growth in certain period of } \\
\text { time }\end{array}$ \\
\hline & $\begin{array}{l}\text { Generated from new } \\
\text { products }\end{array}$ & $\begin{array}{l}{[41][76][18][142][88][122][7} \\
9][124][140]\end{array}$ & $\begin{array}{l}\text { Percent income based on new } \\
\text { products for certain period of } \\
\text { time }\end{array}$ \\
\hline & Increase per employee & [41] & $\begin{array}{l}\text { Percent of revenue growth per } \\
\text { employee in certain period of } \\
\text { time }\end{array}$ \\
\hline & Impact on net profits & {$[99][88]$} & $\begin{array}{l}\text { Percent of revenue that } \\
\text { reflected in net profits for } \\
\text { certain period of time }\end{array}$ \\
\hline & From new platforms & [142] & $\begin{array}{l}\text { Percent income based on new } \\
\text { platforms for certain period of } \\
\text { time }\end{array}$ \\
\hline Market share & & {$[41][43][76][100][118][90]$} & Percentage of market share \\
\hline Brand value & & {$[41][129][125]$} & $\begin{array}{l}\text { Value of company/product as } \\
\text { perceived by customers, } \\
\text { employees, shareholders and } \\
\text { community }\end{array}$ \\
\hline $\begin{array}{l}\text { Customer } \\
\text { satisfaction }\end{array}$ & & {$[41][76][128][118]$} & $\begin{array}{l}\text { Degree of satisfaction of } \\
\text { customer toward company }\end{array}$ \\
\hline Time to profit & & [41] & $\begin{array}{l}\text { Total number of time } \\
\text { (day/month/year) from } \\
\text { research through to sales until } \\
\text { start producing profit }\end{array}$ \\
\hline \multirow[t]{5}{*}{ Bibliometrics } & Scientific Publications & $\begin{array}{l}{[144][43][119][103][137][12} \\
9][126][154][125]\end{array}$ & $\begin{array}{l}\text { Total number of publications } \\
\text { by a company }\end{array}$ \\
\hline & $\begin{array}{l}\text { Literature-Based } \\
\text { Output Indicators }\end{array}$ & {$[130][111][143][112][134]$} & $\begin{array}{l}\text { Literature-based counting of } \\
\text { new products from trades or } \\
\text { journals }\end{array}$ \\
\hline & Number of citations & {$[119][138]$} & $\begin{array}{l}\text { Number of publications by a } \\
\text { company being cited by others }\end{array}$ \\
\hline & Quality of papers & [126] & $\begin{array}{l}\text { Quality of paper published by } \\
\text { a company }\end{array}$ \\
\hline & Presented & [124] & $\begin{array}{l}\text { Total number of publications } \\
\text { that were presented in a }\end{array}$ \\
\hline
\end{tabular}




\begin{tabular}{|c|c|c|c|}
\hline & & & conference \\
\hline $\begin{array}{l}\text { Stock Market } \\
\text { Value }\end{array}$ & & {$[144][61][129]$} & $\begin{array}{l}\text { Value of stock market of a } \\
\text { company }\end{array}$ \\
\hline \multirow[t]{3}{*}{$\begin{array}{l}\text { Sales of new } \\
\text { products }\end{array}$} & & $\begin{array}{l}{[144][76][130][18][131][60][} \\
93][103][155][125] \\
{[136][90]}\end{array}$ & $\begin{array}{l}\text { Percent of sales of new } \\
\text { product in a certain period of } \\
\text { time }\end{array}$ \\
\hline & $\begin{array}{l}\text { Of incrementally } \\
\text { changed products }\end{array}$ & {$[131]$} & $\begin{array}{l}\text { Percent of sales of } \\
\text { incrementally changed } \\
\text { products in a certain period of } \\
\text { time }\end{array}$ \\
\hline & $\begin{array}{l}\text { Of radically changed } \\
\text { products }\end{array}$ & [131] & $\begin{array}{l}\text { Percent of sales of radically } \\
\text { changed products in a certain } \\
\text { period of time }\end{array}$ \\
\hline $\begin{array}{l}\text { Return on } \\
\text { Investment in } \\
\text { new products }\end{array}$ & & {$[76][103][129][125][90]$} & $\begin{array}{l}\text { Number of year from the } \\
\text { beginning of the investment } \\
\text { until it is paid off }\end{array}$ \\
\hline \multirow[t]{4}{*}{$\begin{array}{l}\text { Major } \\
\text { innovation } \\
\text { counts }\end{array}$} & Total & $\begin{array}{l}{[143]} \\
{[60][103][112][106][154][12} \\
1]\end{array}$ & $\begin{array}{l}\text { Total number of major } \\
\text { innovations that happened in } \\
\text { the company for a certain } \\
\text { period of time }\end{array}$ \\
\hline & $\begin{array}{l}\text { Developmental/increm } \\
\text { ental innovation }\end{array}$ & [112] & $\begin{array}{l}\text { Total number of incremental } \\
\text { innovations that happened in } \\
\text { the company for a certain } \\
\text { period of time }\end{array}$ \\
\hline & $\begin{array}{l}\text { Evolutionary/Radical } \\
\text { innovation }\end{array}$ & [112] & $\begin{array}{l}\text { Total number of radical } \\
\text { innovations that happened in } \\
\text { the company for a certain } \\
\text { period of time }\end{array}$ \\
\hline & Based on patents & {$[120]$} & $\begin{array}{l}\text { Total number of patent- based } \\
\text { innovations that happened in } \\
\text { the company for a certain } \\
\text { period of time }\end{array}$ \\
\hline $\begin{array}{l}\text { Productivity } \\
\text { growth indices }\end{array}$ & & {$[143][103]$} & $\begin{array}{l}\text { Indices of a productivity } \\
\text { growth of a company in a } \\
\text { certain period of time }\end{array}$ \\
\hline $\begin{array}{l}\text { Number of } \\
\text { trademarks }\end{array}$ & & {$[67][93]$} & $\begin{array}{l}\text { Total number of trademarks } \\
\text { filed in certain period of time }\end{array}$ \\
\hline $\begin{array}{l}\text { Sales Market } \\
\text { Scope }\end{array}$ & & [67] & $\begin{array}{l}\text { Actual sales for this a certain } \\
\text { project in certain market }\end{array}$ \\
\hline
\end{tabular}




\begin{tabular}{|c|c|c|}
\hline Technometrics & [103] & $\begin{array}{l}\text { Measuring and comparing the } \\
\text { dimensions of technical } \\
\text { performance of a product or } \\
\text { production process }\end{array}$ \\
\hline $\begin{array}{l}\text { Licenses } \\
\text { executed }\end{array}$ & [70] & $\begin{array}{l}\text { Number of licenses being } \\
\text { executed by a company based } \\
\text { on the innovation }\end{array}$ \\
\hline $\begin{array}{l}\text { Start-ups } \\
\text { established }\end{array}$ & [70] & $\begin{array}{l}\text { Number of start-ups } \\
\text { established by a company } \\
\text { based on the innovation }\end{array}$ \\
\hline $\begin{array}{l}\text { Value of } \\
\text { innovation }\end{array}$ & {$[128][125]$} & $\begin{array}{l}\text { Value of the innovation of the } \\
\text { company }\end{array}$ \\
\hline $\begin{array}{l}\text { Quality of } \\
\text { service }\end{array}$ & [128] & $\begin{array}{l}\text { The degree of quality of } \\
\text { service of the company }\end{array}$ \\
\hline $\begin{array}{l}\text { Customer } \\
\text { loyalty }\end{array}$ & [118] & $\begin{array}{l}\text { The degree of customer } \\
\text { loyalty of the company }\end{array}$ \\
\hline $\begin{array}{l}\text { Environmental } \\
\text { impacts }\end{array}$ & [90] & $\begin{array}{l}\text { The environmental impacts } \\
\text { based on innovation of the } \\
\text { company }\end{array}$ \\
\hline $\begin{array}{l}\text { Reduced labor } \\
\text { costs }\end{array}$ & [90] & $\begin{array}{l}\text { Number of reduced labor costs } \\
\text { in a company caused by an } \\
\text { innovation }\end{array}$ \\
\hline
\end{tabular}

\subsection{CONCLUSION OF LITERATURE REVIEW}

Innovation is one of the most important factors in gaining competitive advantage in the business environment. Companies need to measure their innovation in order to gain insights on their innovation capabilities. Companies cannot manage innovativeness if they cannot measure it. Innovation measurement is getting a lot of attention from both academics and the practitioners in business environments. Numerous researchers have conducted studies to investigate the proper way to measure innovation. Mathematical models and various metrics were developed to measure innovation. Consulting 
companies also have performed numerous surveys and questionnaires trying to determine which indicators should be measured.

\subsubsection{Research Findings}

Table 2.3 summarizes the research findings on innovation measurement from the literature review.

TABLE 2.3 FINDINGS OF INNOVATION MEASUREMENT FROM THE LITERATURE REVIEW

\begin{tabular}{|c|c|c|}
\hline $\begin{array}{c}\text { Key Research Areas in } \\
\text { Innovation Measurement }\end{array}$ & Findings & References \\
\hline $\begin{array}{l}\text { 1. Input and output as foci of } \\
\text { innovation measurement }\end{array}$ & $\begin{array}{l}\text { Many researchers use input and } \\
\text { output indicators to measure } \\
\text { innovation. Researchers stress the } \\
\text { importance of output indicators in } \\
\text { measuring innovation, but most of the } \\
\text { research is still predominantly } \\
\text { focused on input. }\end{array}$ & $\begin{array}{l}{[14],[18],[41],[60],} \\
{[65],[68],[69],[72],} \\
{[69][70],[79],[87],} \\
{[89],[94],[103],[105]} \\
{[106],[71],[72],[110]} \\
{[114-116],[74],[118-} \\
123],[75],[125],[127]\end{array}$ \\
\hline $\begin{array}{l}\text { 2. Metrics and methodologies } \\
\text { for measuring innovation. }\end{array}$ & $\begin{array}{l}\text { Surveys, questionnaires, balanced } \\
\text { scorecards, various mathematical } \\
\text { models, and many other methods } \\
\text { have been developed to measure } \\
\text { innovation. } \\
\text { Different standards and } \\
\text { methodologies are being used in } \\
\text { different companies or organizations. }\end{array}$ & $\begin{array}{l}{[18],[41],[43],[67],} \\
{[68],[69],[77],[78],} \\
{[74],[80],[81],[82],} \\
{[83],[82],[85],[85],} \\
{[86],[87],[88],[96],} \\
{[91],[92],[93-95][97],} \\
\text { [98], [99], [100], [101], } \\
{[102],[103],[104],} \\
{[105],[106],[107],} \\
{[108],[109],[114-116],} \\
{[118],[112],[120],} \\
{[125],[113],[128],} \\
{[115],[116]}\end{array}$ \\
\hline $\begin{array}{l}\text { 3. Used of multi-dimensional } \\
\text { approach to measure multi- } \\
\text { attributes of innovation. }\end{array}$ & $\begin{array}{l}\text { Innovation is very complex. A single } \\
\text { indicator is not sufficient to measure } \\
\text { innovation. Several indicators can be } \\
\text { categorized into multiple dimensions } \\
\text { to give a better measurement of } \\
\text { innovation. }\end{array}$ & $\begin{array}{l}{[46],[60],[61],[67],} \\
{[70],[94-96],[137],} \\
{[104],[114],[123],} \\
{[125],[126]}\end{array}$ \\
\hline
\end{tabular}




\subsubsection{Research Gaps}

Six research gaps have been identified in the literature review. Those gaps are:

1. Current output indicators are limited and not broadly investigated. There is a need for more output indicators [14], [111], [130], [131].

2. There is a need to develop a new measurement framework that focuses on innovation outputs [14][111][73][103].

3. Availability of current innovation measurement metrics are not comparable or consistent, making it very difficult to compare the innovation level among companies [79], [114], [143].

4. There is no general conceptual framework to measure innovation in a more reliable, qualitative and quantitative, systematic and effective way [41], [43], [107], [130].

5. There is a lack of research on causal relationships between innovation inputs and outputs [41], [43], [74], [78], [103], [111], [130], [151].

6. Researchers who use the multidimensional approach ignore or barely measure the relative importance of attributes [82], [110], [150].

Five of the gaps $(1,2,3,4$, and 6$)$ are addressed in this research. 


\section{CHAPTER 3: RESEARCH APPROACH}

\subsection{PROBLEM STATEMENT}

Innovation is very important for companies to be able to compete in a global market and to sustain competitive advantage. However, to be able to maintain innovation, a company needs to know its innovativeness. Having metrics to measure innovativeness helps companies to manage their innovation optimally [42]. Information regarding innovation activities within companies will be clearer if the measurement is done correctly [111]. Measurement is not a one-time thing; it needs to be done regularly so that companies can continually realign their strategic decisions [68]. Measuring innovation is subjective and fuzzy due to the nature of innovation itself. However, if the right indicators for the measurement are selected, fuzziness can be reduced, especially since considerable input and output data are available [67]. There is a critical need to develop a measurement instrument that can help companies to measure their innovativeness. Having the right measurement will help companies to make strategic decisions, such as where investments should be made and how resources should be allocated for continuing success.

There is no general framework available to assist companies in measuring their innovativeness. Companies cannot manage innovativeness if they cannot measure it. Numerous innovation measurements have been developed by academics and practitioners and are tailored to each company's specific situation. Thus, it is very difficult to compare innovation levels among companies if it is not done with the same general framework. 
This research develops a measurement framework and metrics so that companies can use it to measure their innovativeness.

\subsection{RESEARCH QUESTION AND OBJECTIVE}

\subsubsection{Research Question}

There is no general conceptual framework to measure innovativeness of a company in the literature, let alone a framework that focuses mainly on output indicators. The way every company measures innovativeness is different. Therefore, it is difficult for a company to benchmark itself to others. Comparisons among companies to find out which one is the most innovative can be made only if everybody is using the same framework. After performing the literature research, the research question is stated as follows:

"What is the most appropriate framework to measure the innovativeness of a company and compare it with other companies?"

A research framework to answer this question was developed. Several factors based on output indicators were identified. The research framework utilizes experts' judgments for measurements. Output indicators such as the number of new products, number of patents, revenue from new products, and number of publications are used. The relative value of each factor is determined through quantification of expert judgments. When the framework is applied to a specific case, the output metrics associated with each factor are obtained for the specific company and the model is used to calculate the 
innovation index for that company. The value of the innovativeness index is a numerical value between 0 and 100 .

\subsubsection{Research Objective}

The objective of this research is to develop a framework and metrics to measure the innovativeness for technological product innovation in technology driven industries, e.g., the semiconductor industry. The measurements help to identify the innovativeness of a company based on output indicators. The results of the measurements provide insight into trends in performance and identify areas that need improvements to amplify the innovation activities in the future [43]. It helps a company to compare its innovativeness to others in the same industry.

The framework calculates the innovativeness of a company as a numerical value. The numerical value expresses how innovative a company is compared to its peers in the same context. This numerical value provides insight into how the company can improve its innovativeness by focusing on areas (factors) that need improvement. Companies will be able to track and review their innovation activities (inputs) and make any changes that can improve their innovation outputs. Having the right measurement will help companies to make strategic decisions.

For the purpose of demonstrating the methodology in this research, the framework is applied to hypothetical companies with the set-up of technology driven industries (e.g., the semiconductor industry) that focus on technological product innovation. 


\subsection{RESEARCH METHODOLOGY}

The innovation measurement research methodology is composed of three stages: hierarchical decision model development, indicators evaluation, and innovativeness evaluation.

Stage 1 - Hierarchical Decision Model Development: Develop a hierarchical model to determine the innovativeness of a company.

Stage 2 - Indicator Evaluation: Develop a measurement for a specific industry using the Delphi method.

Stage 3 - Innovativeness Evaluation: Incorporate the values of the indicators obtained in a company into the model

\subsubsection{Hierarchical Decision Model (HDM)}

This research uses a subjective approach to formulate the framework for innovation measurements. The criteria weights are derived from subjective judgments of experts' perspectives and experiences in the innovation field. The advantage of using the subjective approach is that experts can assign values to decision attributes for which objective measures are not available. A drawback of this approach is that the results are highly subjective because they depend on the experts. However, this drawback can be minimized by selecting panel members with high levels of expertise and by balancing the biases in the panel. Different experts assigned different values, but the disagreements in the panel can be measured and tested for statistical significance [156]. The subjective values could change over time, but the sensitivity of the results to changes in any decision 
element can be determined, and tolerance limits can be identified before any change will take place in the final results [157].

The hierarchical decision model (HDM) is one of the most recognizable methods for subjective approaches [158][159][48]. It is a tool that helps decision makers quantify and incorporate quantitative and qualitative judgments into a complex problem. It was developed from the analytic hierarchical process (AHP) by Saaty as a method for multicriteria decision-making [160] [91]. HDM has been applied in a wide range of applications in different fields for the last 25 years [162][163][164].

The underlying principle of HDM is decomposing problems into hierarchies. It is a comprehensive, logical and structured framework that requires the subjective judgments of the experts to obtain weights for the criteria. Pairwise comparisons among criteria are the key step in the HDM to acquire the priority weights or relative importance of values for each criterion in the hierarchy [165]. The pairwise comparison method compares two criteria at a time and their relationship to each other. The process makes the experts more comfortable because their decisions are based on the relative preference of one criterion over another rather than an absolute preference [166]. The results of the pairwise comparisons from the experts can be verified by checking the consistency of the evaluations [167][48].

Literature research reveals that innovation is complex and cannot be measured by a single attribute. We have identified multiple attributes associated with innovation outputs. In this regard, the problem of innovation measurement is a particularly suitable application for the HDM approach. 


\subsubsection{Judgment Quantification}

The constant sum method is utilized in judgment quantification. In the constant sum method, each expert assigns their subjective judgments by distributing a total of 100 points between two elements at one given time. The subjective judgments are calculated and normalized to get the relative values in a ratio scale of the elements. The methodology used for calculating the subjective judgments is called the Pairwise Comparison Method (PCM).

\subsubsection{Inconsistency}

In this methodology, not only are the relative values of the elements from each expert calculated, but also the inconsistency of each expert is defined. The recommended value of inconsistency is between 0.0 and 0.1 . The following explains the procedure to calculate the inconsistency [168]:

For $\mathrm{n}$ elements, the constant sum calculation results in a vector of relative values $r_{1}, r_{2}, \ldots, r_{n}$ for each of the $n$ ! orientations of the elements. For example, if three elements are evaluated, $n$ is 3 , and $n$ ! is 6 . The 6 orientations would be $\mathrm{ABC}, \mathrm{ACB}, \mathrm{BAC}, \mathrm{BCA}$, $\mathrm{CAB}$, and $\mathrm{CBA}$. If an expert is consistent in providing pairwise comparisons, the relative values are consistent for each orientation. However, if an expert is inconsistent in providing pairwise comparisons, the relative values are inconsistent for each orientation. The inconsistency in this methodology is measured by the variance among the relative values of the elements calculated in the $\mathrm{n}$ ! orientations.

Let $\quad r_{i j}=$ relative value of the $\mathrm{i}^{\text {th }}$ element in the $\mathrm{j}^{\text {th }}$ orientation for an expert 


$$
\begin{aligned}
& \bar{r}_{l}=\text { mean relative value of the } \mathrm{i}^{\text {th }} \text { element for that expert } \\
& \qquad \frac{1}{n !} \sum_{j=1}^{n !} r_{i j}
\end{aligned}
$$

Inconsistency in the relative value of the $\mathrm{i}^{\text {th }}$ element is

$$
\begin{gathered}
\sqrt{\frac{1}{n !} \sum_{j=1}^{n !}\left(\bar{r}_{i}-r_{i j}\right)^{2}} \\
\text { for } \mathrm{i}=1,2, \ldots, \mathrm{n}
\end{gathered}
$$

Variance of the expert in providing relative values for the $\mathrm{n}$ elements is

$$
\text { Inconsistency }=\frac{1}{n} \sum_{i=1}^{n} \sqrt{\frac{1}{n !} \sum_{j=1}^{n !}\left(\bar{r}_{i}-r_{i j}\right)^{2}}
$$

Equation 3.1

\subsubsection{Agreement/Disagreement Among Experts}

The agreement/disagreement level of the experts on the relative importance of the indicators and the relative importance of sub-factors can be determined from the coefficient of intraclass correlation. The coefficient of intraclass correlation describes the degree to which $\mathrm{x}$ judges are in agreement with one another on the relative importance of $\mathrm{n}$ subjects. The formulas for intraclass correlation coefficient are listed as follows:

$$
r_{i c}=\frac{M S_{B S}-M S_{\text {res }}}{M S_{B S}+(k-1) M S_{\text {res }}+\frac{k}{n}\left(M S_{B J}-M S_{\text {res }}\right)}
$$

Equation 3.2 
Where

$$
M S_{B J}=\frac{S S_{B J}}{d f_{B J}}
$$

Equation 3.3

$M S_{B J}=\sum_{j=1}^{k}\left[\frac{\left(\sum X_{j}\right)^{2}}{n}\right]-\frac{\left(\sum X_{T}\right)^{2}}{n k}$

Equation 3.4

$$
d f_{B J}=k-1
$$

Equation 3.5

$$
M S_{B S}=\frac{S S_{B S}}{d f_{B S}}
$$

Equation 3.6

$S S_{B S}=\sum_{i=1}^{n}\left[\frac{\left(\sum S_{i}\right)^{2}}{k}\right]-\frac{\left(\sum X_{T}\right)^{2}}{n k}$

Equation 3.7

$$
d f_{B S}=n-1
$$

Equation 3.8

$$
M S_{\text {res }}=\frac{S S_{\text {res }}}{d f_{\text {res }}}
$$

Equation 3.9

$$
S S_{\text {res }}=S S_{T}-S S_{B J}-S S_{B S}
$$

Equation 3.10

$$
S S_{T}=\sum X_{r}^{2}-\frac{\left(\sum X_{T}\right)^{2}}{n k}
$$

Equation 3.11 


$$
d f_{\text {res }}=(n-1)(k-1)
$$

Equation 3.12

$\mathrm{MS}_{\mathrm{BJ}}$ : Mean square between experts, $\mathrm{SS}_{\mathrm{BJ}}$ : Sum of square between experts, $\mathrm{df}_{\mathrm{BJ}}$ : Degree of freedom between experts, $\mathrm{MS}_{\mathrm{BS}}$ : Mean square between decision elements, $\mathrm{SS}_{\mathrm{BS}}$ : Sum of square between decision elements, $\mathrm{df}_{\mathrm{BS}}$ : Degree of freedom between decision elements, $\mathrm{MS}_{\text {res: }}$ : Mean square residual,

$\mathrm{SS}_{\text {res }}$ : Sum of square residual, $\mathrm{df}_{\text {res }}$ : Degree of freedom residual, $\mathrm{k}$ : Number of experts, $\mathrm{n}$ : Number of decision elements,

Intraclass correlation coefficient $r_{i c}$ theoretically falls between $-1 /(k-1)<$ ric $<+1$ [169]. If the value of $r_{i c}$ in the intraclass correlation coefficient is +1 , it means that there is an absolute agreement among experts on the subject matter. If the value of $r_{i c}$ in the intraclass correlation coefficient is 0 , it means that there is an absolute disagreement among experts on the subject matter. When the value of $r_{i c}$ is negative, it is usually considered as 0 . If the value of $r_{i c}$ in the intraclass correlation coefficient falls between 0 and 1, it means there is a degree of agreement/disagreement among experts. The higher the value of $r_{i c}$, the higher the level of agreement.

An additional agreement/disagreement test can be performed by using F-test since the intraclass correlation only gives a guideline to interpret the degree of agreement/disagreement among experts. Shrout and Fleiss utilized F-test to determine whether there is a statistically significant disagreement among the experts [170]. They used F-test to determine whether $\mathrm{r}_{\mathrm{ic}}$ is equal to zero. The null hypothesis is defined as $\mathrm{H}_{0}$ : 
$r_{i c}=0 . H_{0}: r_{i c}=0$, meaning there is no correlation among the experts on the subject, which indicates absolute disagreement. The $\mathrm{F}$ value is computed as $\mathrm{F}_{\mathrm{BS}}=\mathrm{MS}_{\mathrm{BS}} / \mathrm{MS}_{\mathrm{res}}$.

In this research, if the null hypothesis is rejected at the 0.01 level, the group judgment quantification is accepted. The critical level of 0.01 is used to assure that a high level of agreement has been achieved among the experts in the panels.

\subsubsection{HDM for Innovation Measurement}

The evaluation of the output indicators and sub-factors can be done by a series of calculation procedures. The results from the judgment quantifications from the experts are used as the input in the calculation. The mathematical expression for calculating the contribution of output indicators and sub-factors to the innovativeness is expressed below:

$$
S_{n, j n}^{I X}=\sum_{n=1}^{N} \sum_{j n=1}^{J n}\left(O_{n}^{I X}\right)\left(S_{n, j n}^{O}\right)
$$

Equation 3.13

where

$S_{n, j n}^{I X} \quad$ Relative value of the $\mathrm{jn}^{\text {th }}$ sub-factor under the $\mathrm{n}^{\text {th }}$ output indicator with respect to the Innovation Index (IX)

$O_{n}^{I X} \quad$ Relative priority of the $\mathrm{n}^{\text {th }}$ output indicator with respect to the Innovation Index (IX), $\mathrm{n}=1,2,3, . ., \mathrm{N}$

$S_{n, j n}^{O} \quad$ Relative contribution of the $\mathrm{jn}^{\text {th }}$ sub-factor under the $\mathrm{n}^{\text {th }}$ output indicator, $\mathrm{jn}=1,2$, $3, \ldots, \mathrm{Jn}$, and $\mathrm{n}=1,2,3, \ldots, \mathrm{N}$ 


\subsubsection{Desirability Curve}

A new concept of a desirability curve is implemented in this research. It represents how desirable a metric is for the decision maker. In strategic decision making, decisions are often based not on numerical values of the variables but on the 'goodness' or usefulness of those values. They are referred to as desirability values of the variables.

Three methods can be used for obtaining desirability values:

(1) Standard gamble is the common method of eliciting utilities from decision makers.

This method is appropriate for developing utility functions based on the risk propensity of the decision makers, but it is not the best method for measuring the desirability of outcomes in a deterministic system, and it does not lend itself to determining inconsistencies and disagreements.

(2) The constant-sum method, used for judgment quantifications, is robust and flexible with measurements of inconsistencies and group disagreements.

(3) Marking the relative values for the intervals on a grid presented to the experts is a simple and appropriate method for relatively straightforward assessment of the desirability value.

The shape of the desirability curve could vary. The typical desirability curves are convex, concave, parabolic, or linear (straight line). The following figures depict the typical shape of desirability curves. 

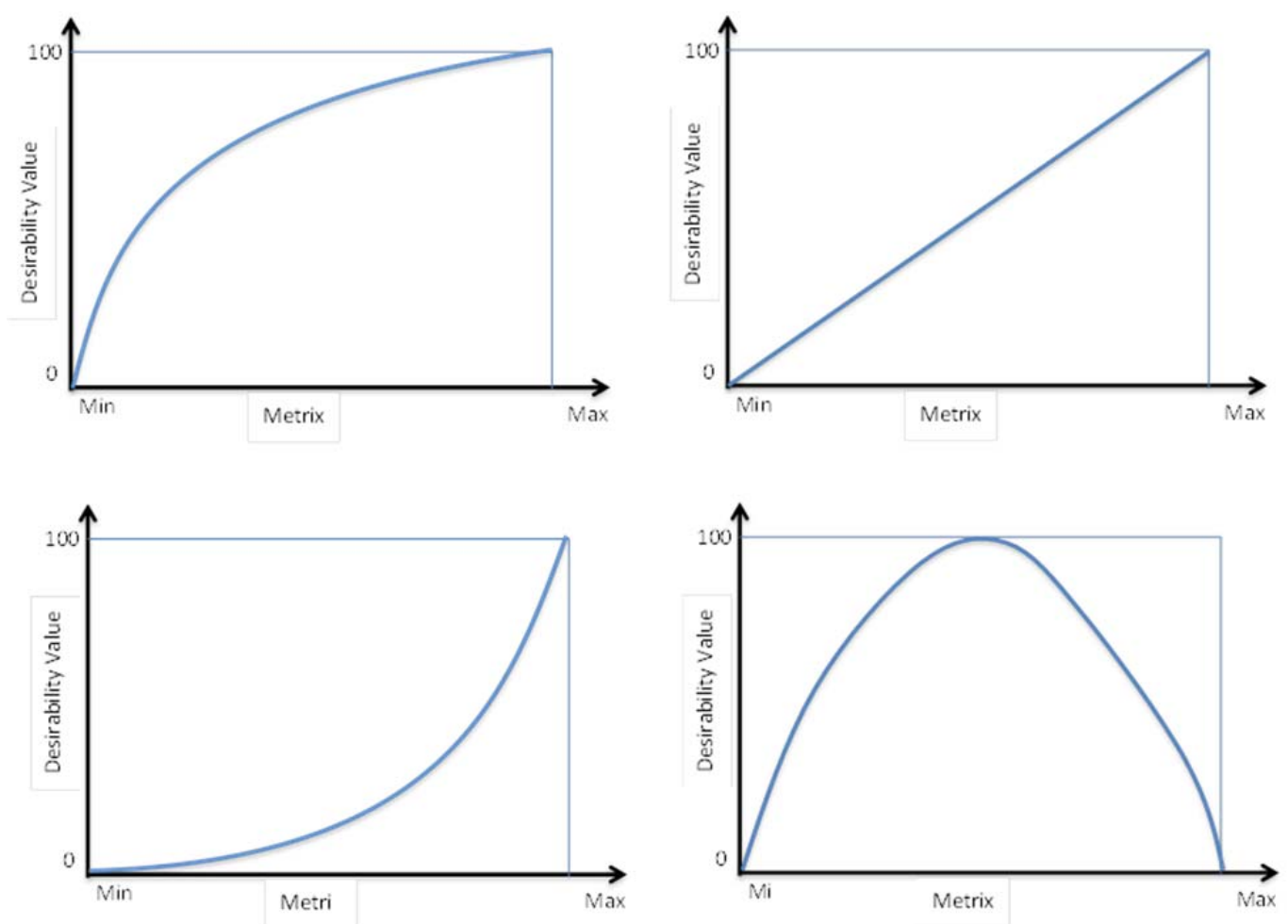

Figure 3.1 Various shapes of desirability curves

The experts express the desirability values of the various levels of the performance measures associated with the sub-factors under the output indicators. When the desirability values are obtained, the innovativeness index of a company can be calculated. The mathematical expression for calculating the innovativeness index is expressed below:

$$
I X=\sum_{n=1}^{N} \sum_{j n=1}^{J n}\left(S_{n, j n}^{I X}\right)\left(D_{n, j n}\right)
$$

Equation 3.14

where

IX Innovation Index 
$S_{n, j n}^{I X} \quad$ Relative value of the $\mathrm{jn}^{\text {th }}$ sub-factor under the $\mathrm{n}^{\text {th }}$ output indicator with respect to the Innovation Index (IX), jn $=1,2,3, \ldots, \mathrm{Jn}$, and $\mathrm{n}=1,2,3, \ldots, \mathrm{N}$

$D_{n, j n}$ Desirability value of the performance measure corresponding to the $\mathrm{jn}^{\text {th }}$ sub-factor under the $\mathrm{n}^{\text {th }}$ output indicator

\subsubsection{Sensitivity Analysis}

Sensitivity analysis of the hierarchical decision model is calculated in this research. The methodology was developed by Chen and Kocaoglu [171] [157]. The sensitivity analysis of the hierarchical decision model is applied to determine the allowance of perturbation induced on each element without any impact on the original ranking based on the innovativeness index [157]. It means that the rankings from the innovativeness index will not change as long as the values of the perturbations remain within the allowable range of values. Chen and Kocaoglu stated that the original ranking of $G_{r}$ and $G_{r+n}$ will not reverse if:

$$
\lambda \geq P_{l^{*}}^{O} * \lambda^{O}
$$

Equation 3.15

for the perturbation $P_{l^{*}}^{O}$ where $-C_{l^{*}}^{O} \leq P_{l^{*}}^{O} \leq 1-C_{l^{*}}^{O}$

where

$$
\begin{gathered}
\lambda=C_{r}^{A}-C_{r+n}^{A} \\
\lambda^{O}=C_{r+n, l^{*}}^{A-O}-C_{r, l^{*}}^{A-O}-\sum_{\substack{l=1 \\
l \neq l^{*}}}^{L} C_{r+n, l}^{A-O} * \frac{C_{l}^{O}}{\sum_{\substack{L \\
l \neq l^{*}}}^{L} C_{l}^{O}}+\sum_{\substack{l=1 \\
l \neq l^{*}}}^{L} C_{r, l}^{A-O} * \frac{C_{l}^{O}}{\sum_{\substack{l=1 \\
l \neq l^{*}}}^{L} C_{l}^{O}}
\end{gathered}
$$

Equation 3.16 
Sensitivity analysis is used for determining the impact of a change in the priority of the elements in the model on the innovativeness index.

\subsubsection{Delphi Method}

The Delphi method is used when the availability of historical, economic and technical information is inadequate. Delphi is a technique for structuring systematic communications among a panel of experts [172]. It is used as an opinion-taking procedure in many different areas of study such as sociology and economics. The Delphi method attempts to minimize an individual's knowledge limitations and possible individual biases.

The Delphi method is different from conventional face-to-face group integration. Three distinct characteristics of the Delphi method are [173][174]:

- Anonymity: Group members do not know each other, preventing any one member from influencing the others. Also, the results are not revealed to any of the members to avoid biases.

- Iteration with controlled feedback: It is done in several iterations. Experts on the panel have the opportunity to reconsider and change their opinions and judgments between several successive iterations.

- $\quad$ Statistical group response: Statistical analysis for each round is performed by Delphi method moderators. Statistical information such as mean, median, and variations of the research are presented. 
The Delphi method can continue for several iterations until the results reach stability. Stability means that there is no significant change between two consecutive rounds. The iteration keeps going on until the stability among any two rounds is obtained. The process of obtaining experts' opinions may cease after stability has been reached. One approach to determine the Delphi method stability is by using chi-square statistical analysis [175][176].

The optimum size of expert panels is between 10 and 15 members. Studies show that the results obtained from panels of that size are sufficiently accurate [173]. Dalkey and Helmer [177], Preble [178] and Martino [179] confirm that the Delphi method that utilizes the judgments from a limited number of experts on the panel produces similar results with a variety of statistical analyses. The Delphi method is applied to obtain experts' opinions on innovation measurements.

\subsubsection{Expert Panel}

The Merriam-Webster dictionary defines an expert as, "A person who has, involves, or displays special skill or knowledge derived from training or experience." In other words, an expert is someone who has an extended or intense experience through practice and education in a particular field [180]. However, an expert is not always necessarily someone who has professional or academic qualifications. Experience in a particular field can qualify somebody to be recognized as an expert [181].

The roles of the experts in this research are as follows:

- Identify critical innovation indicators: 
Lists of output indicators have been identified in the literature, but, not all indicators are used in the framework to determine the innovativeness of a company. Some indicators can be ignored if they do not have significant impact on a specific industry. The experts help to select the critical innovation indicators that determine the innovativeness of a company in a specific industry.

\section{- $\quad$ Provide relative weights for output indicators:}

After output indicators are identified for a specific industry, the experts express their judgments about the relative weights of output indicators. The weights are obtained through the pairwise comparisons method. The pairwise comparisons result in the relative importance, in ratio scale, of the output indicators in that industry.

- $\quad$ Help identify other experts:

The judgments from the experts are very important in order to create a reliable framework to measure innovativeness. The experts are expected to help in identifying other knowledgeable and reputable experts either within the same or different organizations.

- Help gain access to organizations in order to collect data:

Generally, data collection is one of the most challenging processes in conducting research. The experts help in gaining access to organizations for the ease of data collection.

- $\quad$ Validate the model(s) and results: 
After the data collection and judgment quantifications, the role of the experts is extended to validation of the model that has been constructed. Experts are asked to evaluate the acceptability of the model. If there is a disagreement among the experts, the data collection process is repeated until consensus is reached, or the experts agree with the result.

This research has three expert panels to help construct a hierarchical model and to determine the value of each indicator. There are overlaps in the expert panels. The experts represent various sectors (education, government and industry) and different areas of specialization (marketing, sales, legal, new product development, etc.) in the semiconductor industry. Each expert panel has a different role in this research.

\section{Expert Panel 1 (EP1):}

This expert panel is comprised of people from various sectors and different areas of specialization in a specific industry. The different areas of specialization (cross functional) provided different points of view on the output indicators. Examples of different areas of specialization include new product development, marketing, sales, etc. Members of EP1 are leaders in industry and government, and researchers whose work is focused on innovation strategies and measurements. The experts on this panel help to identify output indicators that are recognized as signs of innovativeness in a company. 


\section{Expert Panel 2 (EP2):}

This expert panel is also comprised of people from various sectors and different areas of specialization in a specific industry. The experts in this panel provide quantified judgments on the relative importance of each indicator and sub-factor with respect to the innovativeness.

\section{Expert Panel 3 (EP3):}

This expert panel is comprised of people from various sectors and different areas of specialization in a specific industry. Expert panel 3 (EP3) develops desirability functions for the metrics used for the performance measures corresponding to each subfactors. Therefore, it captures different points of view on what is perceived as innovativeness.

\subsection{IMPLEMENTING THE RESEARCH APPROACH IN A SPECIFIC CASE}

As part of this research, the approach described in the previous section is demonstrated with an example from the semiconductor industry. Five hypothetical hightech companies are considered for the purpose of demonstration. The profiles of the hypothetical companies vary from one another to give a deeper understanding of the decision model.

Detailed information about the high tech industry and semiconductor industry is provided in Chapter 4. 


\subsection{VALIDATION OF THE RESEARCH}

This research is validated using three major validation approaches:

\section{Construct Validity}

The construct of the model was validated by presenting the model to a select group of experts to verify the appropriateness of the structure.

- Content Validity

Content validity tested the readiness of the instruments to collect the data from the respondents.

- $\quad$ Criterion-Related Validity

Unlike content and construct validity that were performed in the beginning, criterion-related validity was performed after the results of this study were obtained. The experts examined whether the results of the model are acceptable. The experts were also asked to verify if the model is generalizable and applicable for measuring innovativeness in other industries. 


\section{CHAPTER 4: RESEARCH APPLICATION}

\subsection{RESEARCH SCOPE}

Innovation is a broad topic, and there are several types of innovation. The objective of this research is to investigate the topic of innovation measurement and to develop measurement processes and metrics for technological product innovation in technology driven industries, e.g., the semiconductor industry.

Researchers have examined the topic of how to measure technological product innovation. Input, process and output are used as indicators. Inputs have been used for a long time and are more common measurements than outputs. This research focuses on measuring the innovativeness of companies based on output indicators.

Outputs of innovation cannot be controlled or predicted [78]. Meanwhile, input and process are controllable. Measuring innovation on the basis of input and process can bias the results. For example, a company can increase the R\&D expenditure (input) as high as it wants. However, that increase does not necessarily mean that the company is more innovative. An increase in input does not always lead to an increase in innovativeness if the outputs remain the same. Therefore, a more appropriate measure of the innovativeness of a company is one based on output indicators. Outputs usually transform innovation activities into economic value for companies [18]. If the output measurement is made correctly, companies can track and review innovation inputs to determine what needs to be done to improve innovation outputs [18]. 


\subsection{PRODUCT INNOVATION}

There are several types of innovation, e.g., product innovation, process innovation, marketing innovation, and organizational innovation. For the purpose of this research, product innovation was chosen as the application area.

The focus of product innovation is the introduction of new or improved goods in terms of technical specifications, user friendliness, components, materials, or other functional characteristics [66].

For the modern corporation, new product success is vital to growth and prosperity [182]. Companies that are successful today are doing well at creating successful new products. Product innovation has been proven as the critical driver for business success. In addition, it is an essential strategic approach for creating competitive advantages in the dynamic and global business environment [183]. Many companies focus on product innovation to increase profitability and growth.

However, creating successful innovation in products is not easy. Few companies can convert the success of product innovation into stellar financial performance [182]. A company that can successfully transform product innovation into profitability and growth is the result of a disciplined and systematic approach [182].

Product innovation focuses on integrating the capabilities and resources of a company in a way that the results of it exceed customer and stakeholder expectations. The definition of product innovation in the broad perspective is creating new products [183].

Product innovation is multidimensional and requires collaboration from every function within an organization [183]. According to Rainey, "Product innovation is 
driven by the enthusiasm of success, not by the risk of failure" [183]. Therefore, if a product innovation is successful, we can assume that the company is innovative in its operation.

\subsection{TECHNOLOGY DRIVEN INDUSTRY}

There are many industries that focus on product innovation. This research focuses specifically on technology-driven industries that concentrate on product innovation.

Every company creates new products and hopes to deliver value to its customer, be profitable, and at the same time establish leadership in the market. Many companies are trying to achieve that. They explore different approaches to deliver the product, e.g., technology driven, sales driven and market driven [184].

This research focuses on product innovation, especially in technology-driven industries. The characteristics of technology-driven industries are that they can develop technology, design new products based on that technology, and create markets for their products because they are technologically superior to the competitors [184]. Technologydriven industry realizes that technology matters when it comes to driving growth [185]. Thus, the business strategies are technology oriented. When the market insight and the technological insight intersect, that is where the innovation emerges [185].

The following are the principles of innovative companies driven by technology [185]:

- $\quad$ Consider technology as the core input

Instead of looking at technology as an enabler, consider technology as the primary input to the business strategy. 
- $\quad$ Re-examine the strategy and technology context on a regular basis

Technology is changing at a fast pace. Companies continuously manage and revise their strategies according to the evolving technology environment.

- $\quad$ Distinctively manage emerging business opportunities

A company is proactively exploring emerging business opportunities than managing the regular core business. By doing that, the innovations will have more possibility to emerge.

- $\quad$ Plan for disruptions

Not only technology, but also markets change at a fast pace. Innovative technology-driven companies anticipate and actively plan how to disrupt the business to dominate the market.

- $\quad$ Manage for today's and tomorrow's context

Companies usually sustain current technology to keep up with the current pace of innovation and also prepare for emerging technologies that might create new markets or potentially disrupt current markets.

- $\quad$ Focus technology on customer priorities

Companies usually concentrate on problems that their customers are facing and identify technologies that can overcome the problems.

\subsection{SEMICONDUCTOR INDUSTRY}

The semiconductor industry has been growing rapidly for the past 40 years [186] . According to the World Semiconductor Trade Statistics (WSTS), the semiconductor market is expected to reach $\$ 356.6$ billion in 2013 [187]. It is one of the industries with a 
fast growing pace with an annual average growth of $10 \%$ [186]. The semiconductor industry also provides the technology for America's \$1.1 trillion high-tech industries [187]. It has a significant impact on society and has been driving our modern electronic era, where it is used in cars, trains, aircraft, home appliances, computers, and consumer electronics [186] [187]. The various applications of the semiconductor industry have improved the quality of life significantly. The success of the semiconductor industry has also improved many other industries such as computers, networks, information technologies, entertainment, health care and defense [188].

One of the most obvious characteristics of the semiconductor industry is the high pace of innovation activities.

As Moore's law states, the number of transistors that can be placed in a single computer chip will double within the time span of 18-24 months [186]. The law has been proven correct over the last four decades.

In addition to the high pace of innovation activities, the other important characteristics of the semiconductor industry are high capital intensity, R\&D intensity, high growth, dynamic markets, high degree of globalization, rigorous competition, and intellectual capital creation [189].

Following are trends in the semiconductor industry that define the industry in the modern era [190]:

- The competition has shifted from processing technologies to product design, architecture, algorithm, software, and lifecycle evolution in which innovation plays a crucial supporting role. The cost of R\&D and production facilities is significant. 
- The lifecycles of the products are becoming shorter.

- $\quad$ Improvements in manufacturing processes are assisted by increased modeling and simulation for nanotechnologies.

- There are increasing demands for more bandwidth due to the digitization of everything and the need to decrease latency.

Without adequate innovation capability, companies in the semiconductor industry will not be able to survive. The latest technology is utilized to improve the essential aspects of the industry, which are production capacity, sizes of the feature, advance functionality and wafer sizes [186]. R\&D is necessary for companies to improve those aspects in order to survive the dynamics of the industry [191].

The importance of the semiconductor industry in the world, especially in the U.S., along with its continual effort to generate new and innovative products, makes it ideal as an application of the research approach in this thesis. The semiconductor industry constantly drives the innovation that leads to many new and innovative products being introduced every year, which makes it idyllic as a case study to test the framework. The framework developed in this research will help companies in the semiconductor industry measure their innovativeness. Because the innovation capability of a company in the semiconductor industry is critical, it is essential for a company to remain innovative. Having a measurement framework will help a company in the semiconductor industry to be able to measure its innovativeness and compare it with its peers. The implications from the framework can assist a company in understanding its innovation competencies so that it can compete in the fast pace of the semiconductor industry. 


\section{CHAPTER 5: EXPERT PANELS FORMATION, MODEL DEVELOPMENT AND}

\section{DATA COLLECTION}

The research approach in this thesis is applied to the measuring product innovation in the semiconductor industry. As mentioned in Chapter 4, the measurement of innovation is often accomplished by using inputs and outputs. However, to demonstrate the research approach in this thesis, the measurement is based on output indicators only. The reason for choosing output indicators is not to simplify the measurement, but merely because output indicators cannot be manipulated. Measuring innovativeness needs to be objective to avoid biases that lead to incorrect information.

There are three main sections in this chapter. The first section describes the formation of the expert panels. The second section explains the development of the hierarchical decision model for innovation measurement. The third section discusses the process of collecting data from the expert panel.

\subsection{EXPERT PANELS FORMATION}

This research requires involvement from experts in the field to help with the model development. Quantification of expert judgments to the model is as important. For the purpose of this research, three expert panels were formed. The experts were selected for their expertise in their fields of innovation, including academia (scientists, researchers), industry (high level managers and engineers), and government (decision makers). The experts were not introduced to each other in order to avoid biases. Data 
from the experts have a major impact on the outcome of this research. Thus, the selection criteria are crucial.

\subsubsection{Criteria to Select Expert Panel Members}

From the literature, several criteria were identified for the process of selecting experts.

- $\quad$ Compatibility of the expertise with the research area [192]

The knowledge of the expert has to be well-matched with the research area. The process of matching the expertise and the research area has to be done carefully. In this research, experts are identified who have the expertise and in-depth understanding of the concept of innovation. The experts should understand what indicators can be used to articulate the innovativeness of a company.

- In-depth understanding of the subject / Level of expertise [193][192]

The experts should be at the top of their fields of technical or scientific knowledge. If an expert is from academia, he/she must have several publications related to the subject. The number of publications and cited works helps to identify the level of expertise. If the expert is from industry, the level of expertise will be determined by his/her position. For example, a person who is a decision maker in an organization is considered to be an expert who has a certain level of expertise; otherwise, he/she would not be the decision maker. Usually, a person who has the authority to make decisions also possesses a certain kind of position in an organization. Another indicator of the level of expertise in an industry is 
how long a person has been working on the subject matter. For example, someone who has worked for 15 years as a project manager will have more knowledge and experience than a person who just started as a project manager. In this research, the experts are from both academia and industry. If they are from academia, they are required to have publications related to innovation, especially innovation measurements. Citation network analysis helps in identifying the level of expertise by looking at the number of publications and how often they are cited by others working in the same research area. Experts from industry are those in decision-making positions in the organization and working in an area close to this research area for a specified amount of time. The experts will have experience in managing innovation.

- $\quad$ Reputation of the experts in the subject matter, either national or international [194]

The reputation of the expert is important. The credibility of the experts adds reliability to the outcome of this research. From academia, one way to evaluate reputation is from citation network analysis. The number of papers cited gives an illustration of the influence and reputation of the expert in the area. If the expert is from industry, the roles, responsibilities and position of the expert in the organization are indicators of the reputation. In addition, reputation is recognized if the expert has received references/acknowledgements regarding his/her expertise from his/her peers who work in the same area. For example, the 
"snowball" method helps to indicate the reputation of an expert. The more recommendations given by his/her peers, the higher his/her reputation is.

- $\quad$ Availability and willingness to participate during the study timeline [194]

The availability and willingness to participate during the study timeline is very important. An expert with a stellar reputation and in-depth knowledge will not help the research if he/she cannot commit during the timeline of the research.

- $\quad$ Ability to see connections between national and international, between present and future, and between different fields of science [193]

In this research, the experts have to be able to see the connection among indicators used for innovativeness in the past and indicators used nowadays. Experts need to identify if the indicators are comparable nationally and internationally.

- $\quad$ Point of View [193]

An expert should possess an ability to cross over traditional viewpoints and look at the problems, not only from a known and safe point of view, but also from unconventional angles. The expert has to be interested and open to a wide range of knowledge and not limited to his/her own field.

\section{- $\quad$ Balanced perspectives and biases [195][196]}

The experts were selected from different departments within an organization in order to balance perspectives and biases. For example, if all experts are selected from only science and engineering departments, the results are distorted in favor of engineers' point of view. We selected a range of experts from various 
departments within an organization to balance perspectives and biases, including marketing, sales, and R\&D.

- $\quad$ Balanced industry representatives [195][196]

The framework in this research measures the innovativeness of companies within the same industry. In order to have a conceptual general framework to measure innovativeness in that specific industry, the experts come from different representatives in that industry.

\section{- $\quad$ Balanced sector representatives [195][196]}

Even though this research is illustrated by measuring innovativeness of companies within a specific industry, the experts are not only from the industry sector. Experts from government and academia are included to get a broader and more comprehensive assessment. Balancing sector representatives by including experts from academia and government helps industry leaders see innovation from different angles.

\section{- $\quad$ Avoid dominance by loudness}

Opinions vary during the data collection from experts. It is common to see some experts speak louder than others to express their opinions, which can influence the results. Usually, the results are tilted toward the opinion of one or two experts who may establish dominance by loudness of voice, eye contacts, body movements, etc. This is avoided in this research because data are not collected in group meetings. They are collected through email and one-on-one phone conversations. 
- $\quad$ Avoid silent bystanders

Another common situation that occurs in data collection is the experts not expressing their opinions because of shyness. A silent bystander chooses to be silent and refuses to be vocal in order to avoid conflict with other experts. Some experts who are silent bystanders might have great opinions, but those opinions could be lost. This issue is also avoided because, as previously noted, data are collected through e-mail and one-on-one phone conversations instead of group meetings.

\subsubsection{Expert Panels Profile}

The experts were selected from academic, industry, and government sectors. They are from all over the world, including but not limited to Germany, Netherlands, Australia, China, UK, and South Korea.

After the list of the experts was finalized, their contact information was collected. The researcher used email as the main communication channel with the experts. The research topic, objective, and scope were explained in the email. If they agreed to participate, the data collection instruments were sent to the experts. A total of 40 people served on three expert panels, and most of them served on more than one panel.

\section{Expert Panel 1 (EP1):}

There were 30 experts on Expert Panel 1 (EP1). The experts were from various sectors (academic, industry, and government) and countries. They also came from different areas of specialization within the semiconductor industry. EP1 identified output 
indicators that contribute to the innovativeness in the industry. The roles of the experts on this panel included researcher, professor, department director, technology manager, department chair, research director, director of business unit, program/project manager, engineer, and vice president of business unit. Table 5.1 summarizes the experts' profiles.

TABLE 5.1 DISTRIBUTION AND BACKGROUND OF EXPERT PANEL 1

\begin{tabular}{|c|c|c|c|c|c|}
\hline & Industry & Government & Academia & Affiliation & Country \\
\hline EXP1 & & & $x$ & University of Bamberg & Germany \\
\hline EXP2 & & & $x$ & Delft University of Technology & Netherlands \\
\hline EXP3 & & & $x$ & University of Bamberg & Germany \\
\hline EXP4 & & & $x$ & Erasmus University & Netherlands \\
\hline EXP5 & & & $x$ & University of Exeter & UK \\
\hline EXP6 & & & $x$ & $\begin{array}{l}\text { German Graduate School of } \\
\text { Management \& Law }\end{array}$ & Germany \\
\hline EXP7 & & & $x$ & University of Manchester & UK \\
\hline EXP8 & & & $x$ & INRS & Canada \\
\hline EXP9 & & & $x$ & University of Bologna & Italy \\
\hline EXP10 & & & $x$ & $\begin{array}{l}\text { Melbourne Institute of Applied } \\
\text { Economic and Social Research }\end{array}$ & Australia \\
\hline EXP11 & & & $x$ & $\begin{array}{l}\text { German Graduate School of } \\
\text { Management \& Law }\end{array}$ & Germany \\
\hline EXP12 & & & $x$ & Fuzhou University & China \\
\hline EXP13 & & & $x$ & Innovation IMS Instruction & USA \\
\hline EXP14 & & & $x$ & Korea University & South Korea \\
\hline EXP15 & $x$ & & & $\mathrm{PwC}$ & USA \\
\hline EXP16 & $x$ & & & $\begin{array}{c}\text { IPR \& Innovation at Crompton } \\
\text { Greaves Ltd }\end{array}$ & India \\
\hline EXP17 & $x$ & & & TriQuint Semiconductor & USA \\
\hline EXP18 & $x$ & & & Intel Corporation & USA \\
\hline EXP19 & $x$ & & & Cascade Mictotech & USA \\
\hline EXP20 & $x$ & & & FEI Company & USA \\
\hline EXP21 & $x$ & & & Lattice Semiconductor & USA \\
\hline EXP22 & $x$ & & & Intel Corporation & USA \\
\hline EXP23 & $x$ & & & TOK America & USA \\
\hline EXP24 & $x$ & & & Intel Corporation & USA \\
\hline EXP25 & $x$ & & & Intel Corporation & USA \\
\hline EXP26 & $x$ & & & Tektronix, Inc. & USA \\
\hline EXP27 & $x$ & & & Intel Corporation & USA \\
\hline EXP28 & $x$ & & & Tektronix, Inc. & USA \\
\hline EXP29 & $x$ & & & Novellus System & USA \\
\hline EXP30 & & $x$ & & Italian National Research Council & Italy \\
\hline
\end{tabular}




\section{Expert Panel 2 (EP2):}

There were 36 experts on Expert Panel 2 (EP2).The experts were from various sectors (academic, industry, and government) and countries. They also came from different areas of specialization within the semiconductor industry, to balance the perspectives on the subject matter. EP2 provided judgment quantifications for the relative importance of output indicators and sub-factors with respect to the innovativeness. The titles of the experts on this panel included a researcher, professor, department director, technology manager, department chair, research director, director of business unit, program/project manager, engineer, and vice president of business unit. Table 5.2 summarizes the experts' profiles.

TABLE 5.2 DISTRIBUTION AND BACKGROUND OF EXPERT PANEL 2

\begin{tabular}{|c|c|c|c|c|c|}
\hline & Industry & Government & Academia & Affiliation & Country \\
\hline EXP1 & & & $\times$ & Delft University of Technology & Netherlands \\
\hline EXP2 & & & $\times$ & INRS & Canada \\
\hline EXP3 & & $\times$ & $\begin{array}{c}\text { German Graduate School of } \\
\text { Management \& Law }\end{array}$ & Germany \\
\hline EXP4 & & & $\times$ & $\begin{array}{c}\text { German Graduate School of } \\
\text { Management \& Law }\end{array}$ & Germany \\
\hline EXP5 & & & $\times$ & University of Bamberg & Germany \\
\hline EXP6 & & & $\times$ & University of Bamberg & Germany \\
\hline EXP7 & & & $\times$ & Korea University & South Korea \\
\hline EXP8 & & & $\times$ & University of Bologna & Italy \\
\hline EXP9 & & & $\times$ & Fuzhou University & China \\
\hline EXP10 & & & $\times$ & Erasmus University & Netherlands \\
\hline EXP11 & & & $\times$ & Indian Institute Technology & India \\
\hline EXP12 & & & $\times$ & University of Exeter & UK \\
\hline EXP13 & & & $\times$ & University of Manchester & UK \\
\hline EXP14 & & & & Samsung Electronic Research & South Korea \\
\hline EXP15 & $\times$ & & & Institute & USA \\
\hline EXP16 & $\times$ & & & Lattice Semiconductor & USA \\
\hline EXP17 & $\times$ & & & FEI Company & USA \\
\hline EXP18 & $\times$ & & & TOK America & USA \\
\hline EXP19 & $\times$ & & & Tektronix, Inc. & USA \\
\hline EXP20 & $\times$ & & & & USA \\
\hline
\end{tabular}




\begin{tabular}{|c|c|c|c|c|c|}
\hline EXP21 & $\times$ & & & Tektronix, Inc. & USA \\
\hline EXP22 & $\times$ & & & Tektronix, Inc. & USA \\
\hline EXP23 & $\times$ & & & Intel Corporation & USA \\
\hline EXP24 & $\times$ & & & Intel Corporation & USA \\
\hline EXP25 & $\times$ & & & Intel Corporation & USA \\
\hline EXP26 & $\times$ & & & Intel Corporation & USA \\
\hline EXP27 & $\times$ & & & TriQuint Semiconductor & USA \\
\hline EXP28 & $\times$ & & & TriQuint Semiconductor & USA \\
\hline EXP29 & $\times$ & & & TriQuint Semiconductor & USA \\
\hline EXP30 & $\times$ & & & PwC & USA \\
\hline EXP31 & $\times$ & & & Cascade Mictotech & USA \\
\hline EXP32 & $\times$ & & & Novellus System & USA \\
\hline EXP33 & $\times$ & & & IPR \& Innovation at Crompton & India \\
& $\times$ & & & Treaves Ltd & USA Instruments \\
\hline EXP34 & $\times$ & $\times$ & & Italian National Research Council & Italy \\
\hline EXP35 & & $\times$ & & $\begin{array}{c}\text { Oregon Business Innovation } \\
\text { Council }\end{array}$ & USA \\
\hline EXP36 & & & & & \\
& & & & & \\
\hline
\end{tabular}

\section{Expert Panel 3 (EP3):}

There were 30 experts on Expert Panel 3. The experts represented various sectors (academic, industry, and government) and countries. They came from different areas of specialization within the semiconductor industry. EP3 developed desirability functions for the metrics used for the performance measures corresponding to each of the subfactors. The experts on this panel include researchers, professors, department directors, technology managers, department chairs, research directors, directors of business unit, program/project managers, engineers, and vice presidents of business unit. Table 5.3 summarizes the experts' profiles. 
TABLE 5.3 DISTRIBUTION AND BACKGROUND OF EXPERT PANEL 3

\begin{tabular}{|c|c|c|c|c|c|}
\hline & Industry & Government & Academia & Affiliation & Country \\
\hline EXP1 & & & $x$ & $\begin{array}{l}\text { Delft University of } \\
\text { Technology }\end{array}$ & Netherlands \\
\hline EXP2 & & & $x$ & INRS & Canada \\
\hline EXP3 & & & $x$ & $\begin{array}{l}\text { German Graduate School of } \\
\text { Management \& Law }\end{array}$ & Germany \\
\hline EXP4 & & & $x$ & $\begin{array}{l}\text { German Graduate School of } \\
\text { Management \& Law }\end{array}$ & Germany \\
\hline EXP5 & & & $x$ & University of Bamberg & Germany \\
\hline EXP6 & & & $x$ & University of Bamberg & Germany \\
\hline EXP7 & & & $x$ & Korea University & South Korea \\
\hline EXP8 & & & $x$ & University of Bologna & Italy \\
\hline EXP9 & & & $x$ & Fuzhou University & China \\
\hline EXP10 & & & $x$ & Erasmus University & Netherlands \\
\hline EXP11 & & & $x$ & University of Exeter & UK \\
\hline EXP12 & & & $x$ & University of Manchester & UK \\
\hline EXP13 & & & $x$ & Innovation IMS Instruction & USA \\
\hline EXP14 & $x$ & & & $\begin{array}{l}\text { Samsung Electronic Research } \\
\text { Institute }\end{array}$ & South Korea \\
\hline EXP15 & $x$ & & & $\begin{array}{l}\text { TOK America } \\
\end{array}$ & USA \\
\hline EXP16 & $x$ & & & Tektronix, Inc. & USA \\
\hline EXP17 & $x$ & & & Tektronix, Inc. & USA \\
\hline EXP18 & $x$ & & & Tektronix, Inc. & USA \\
\hline EXP19 & $x$ & & & Tektronix, Inc. & USA \\
\hline EXP20 & $x$ & & & Intel Corporation & USA \\
\hline EXP21 & $x$ & & & Intel Corporation & USA \\
\hline EXP22 & $x$ & & & TriQuint Semiconductor & USA \\
\hline EXP23 & $x$ & & & TriQuint Semiconductor & USA \\
\hline EXP24 & $x$ & & & $\mathrm{PwC}$ & USA \\
\hline EXP25 & $x$ & & & Cascade Mictotech & USA \\
\hline EXP26 & $x$ & & & Novellus System & USA \\
\hline EXP27 & $x$ & & & $\begin{array}{c}\text { IPR \& Innovation at } \\
\text { Crompton Greaves Ltd }\end{array}$ & India \\
\hline EXP28 & $x$ & & & Texas Instruments & USA \\
\hline EXP29 & & $x$ & & $\begin{array}{c}\text { Italian National Research } \\
\text { Council }\end{array}$ & Italy \\
\hline EXP30 & & $x$ & & $\begin{array}{c}\text { Oregon Business Innovation } \\
\text { Council }\end{array}$ & USA \\
\hline
\end{tabular}

\subsubsection{Obtaining Consent and Collecting Data from Experts}

The researcher identified experts from academic, industry and government sectors. After the list of the experts was finalized, the researcher sent email to the experts to invite them to take part in the research. The details about the research, data collection 
process, and human subject protection were included in the email. Before the data collection instruments were sent, each expert was asked to indicate whether they agree to be in the expert panel by replying to the email. There were a total of 40 experts in Expert Panels 1, 2, and 3 .

After the experts agreed to take part in the research, each expert spent an average of 10-20 minutes on each survey instrument. The researcher sent the survey instrument link to the experts by email. If the experts had any questions, they were asked to send an email to the researcher to clarify the survey instruments.

After the responses from the experts were collected, the researcher analyzed the data and checked for differences in opinion. A follow-up email was sent to the experts to ask for supplemental opinions to either verify or change their responses based on the result of the analysis. The individual results from each expert were not divulged to the other panel members. To validate the data, the individual inconsistency and group disagreement were calculated.

\subsection{MODEL DEVELOPMENT}

The hierarchical decision model (HDM) of this research was constructed using the information obtained from the literature research. After output indicators were identified, EP1 helped the researcher to identify output indicators and sub-factors that contribute to measuring the innovativeness of a company through a series of Delphi processes. EP1 determined which output indicators should and should not be included. In addition, EP1 also added output indicators that are not identified in the literature review. The process was repeated for several cycles until the HDM was finalized and verified by 
the experts. Research instrument 1 (RI1), a web-based survey instrument, was created for the model development. The screen capture of RI1 is presented in Appendix A.

The HDM model for innovation measurement consists of a three-level hierarchy as shown in Figure 5.1. The output indicators and sub-factors were identified through the literature research and experts' judgments.

\subsubsection{Mission Level}

The first level of the HDM is the mission of this research, which is to identify the innovativeness index (innovation measurement) of a product innovation in a high-tech industry, e.g., the semiconductor industry. The mission is also applicable to other types of innovation and industries by modifying some elements to fit the needs. The mission of this research is measuring the innovativeness of a company by developing an innovativeness index in order to provide a framework for a company in the semiconductor industry to benchmark itself against its competitors in the same industry.

\subsubsection{Output Indicators}

The second level of the HDM lists the output indicators that contribute to the innovativeness of a company in the semiconductor industry. By excelling in all output indicators, a company will achieve the mission to have a high innovativeness index. The output indicators in the second level are described below:

1. Number of New Products: This output indicator refers to the total number of new products that are released to the market by a company. 
2. Number of Awards and Honors: This output indicator refers to the total number of awards or honors received by a company.

3. Number of Patents: This output indicator refers to the total number of patents by a company.

4. Revenue from New Products: This output indicator refers to the revenue a company receives from a new product.

5. Number of Publications: This output indicator refers to the total number of publications by a company.

6. Market Share: This output indicator refers to the market share achieved by a company.

\subsubsection{Sub-Factors}

The third level of the HDM is output indicators. It consists of the sub-factors which are breakdowns from the output indicators. The sub-factors provide a more comprehensive measure of a company's innovativeness. Those sub-factors are:

1. Number of new products that are new to the world: This sub-factor is the total number of new products that are developed by the company and are new to the world.

2. Number of new products that are new to the company: This sub-factor is the total number of new products that are developed by the company and are new to the company.

3. Number of innovation awards: This sub-factor is the total number of innovation awards received by the company. 
4. Number of innovation honors: This sub-factor is the total number of innovation honors received by the company.

5. Number of patents filed: This sub-factor is the total number of patents filed by the company.

6. Number of patents granted: This sub-factor is the total number of patents the companies are granted.

7. Number of patents cited: This sub-factor is the total number of patents of a company cited by others.

8. Number of papers in scientific publications: This sub-factor is the total number of papers by a company that are published in scientific publications.

9. Number of papers presented: This sub-factor is the total number of papers by a company that are presented at conferences.

10. Number of papers cited: This sub-factor is the total number of papers by a company that are cited by others. 


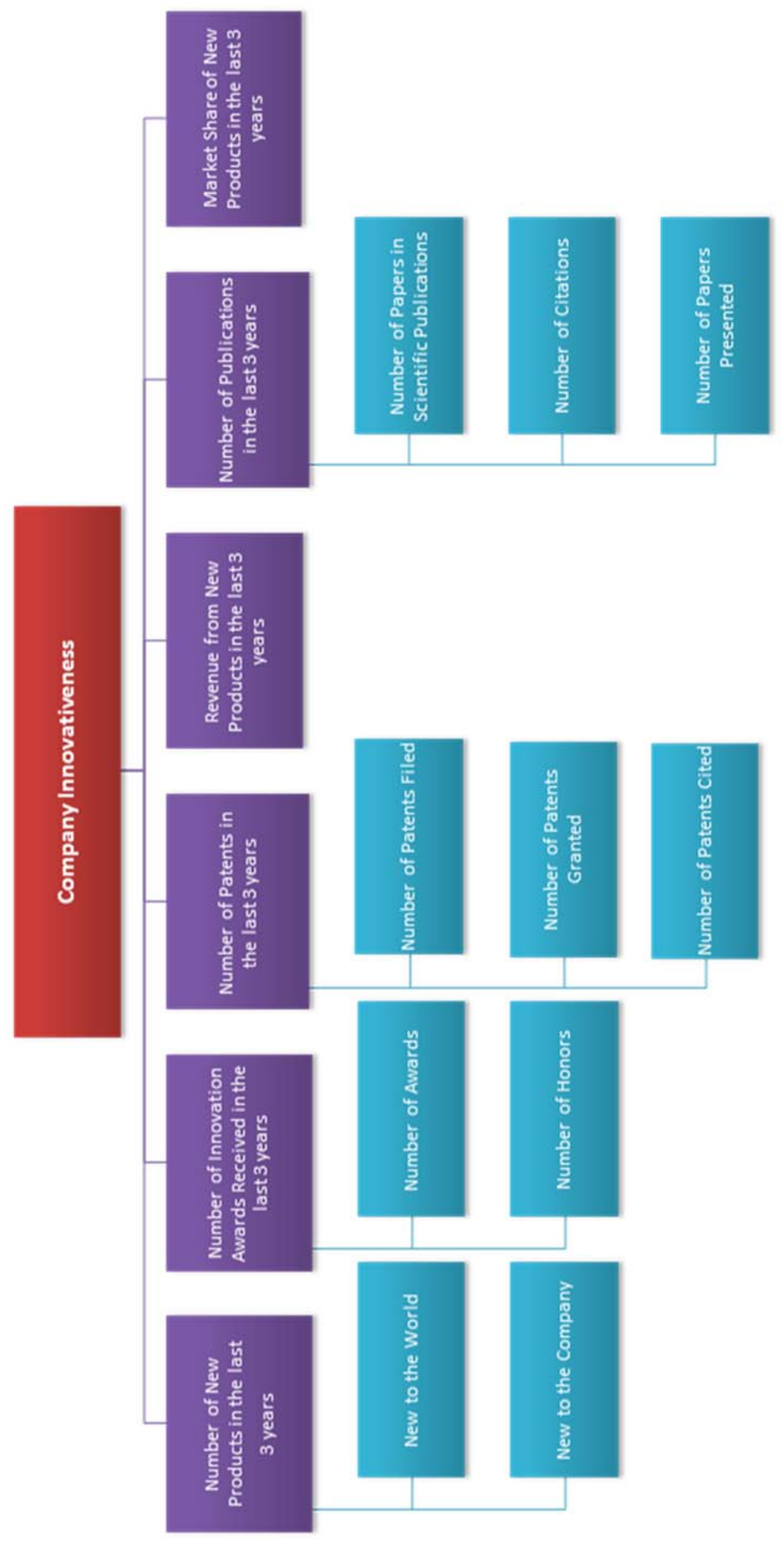

Figure 5.1 Model of the Innovation Measurement 


\subsection{DATA COLLECTION}

The previous sub-chapter discussed that the model of innovation measurement was constructed from literature research. The model was then sent to EP1 for validation. The validation process took several iterations.

After the HDM was finalized by EP1, three research instruments were created for the purpose of the data collection in addition to RI1, which was used for model development. Research instrument 2 (RI2) was used by EP2 to evaluate the relative importance of the output indicators with respect to the innovativeness. Research instrument 3 (RI3) was used by EP2 to evaluate the relative importance of sub-factors with respect to the output indicators. Research instrument 4 (RI4) was used by EP3 to express their desirability toward the metrics that contribute to the innovativeness of a company. Research instruments 2, 3, and 4 are attached in Appendix A.

Each instrument consists of an invitation letter and the link to the survey instrument.

1. Invitation letter

The invitation letter is sent by email. The invitation letter consists of the researcher's brief information, including name, affiliation and research topic. It also presents the human subjects and confidentiality issues to the experts. At the end of the letter, a web-link is provided. Experts are asked to click the link and provide their judgments through the web-based survey instruments, which were created to make the process of data collection faster and more convenient for the experts. 
2. Web-link to the survey instrument

The web-link for each research instrument of the web-based survey is different.

a. Web-link for RI2

The web-link for RI2 is used to collect the expert judgments on the output indicator levels. When the experts click the web-link for RI2, they are asked to provide their name. The instructions for using pairwise comparisons are provided on the web-page. Experts are asked to allocate a total of 100 points between two output indicators at a time according to their relative importance to the innovativeness. The web-based survey lists all the possible comparisons of output indicators with a moveable bar between them. A small box to solicit the comments from experts was also provided.

b. Web-link for RI3

A web-link for RI3 is used to collect the expert judgments on the subfactors level. When the experts click the web-link for RI3, they are asked to provide their name. The instructions for using pairwise comparisons are listed on the web-page. Experts are asked to allocate a total of 100 points between two sub-factors at a time according to their relative importance to the output indicators. The web-based survey lists all the possible comparisons of sub-factors with a drag-able bar between them. A small box to solicit the comments from experts was also provided. 


\section{c. Web-link for RI4}

A web-link for RI4 is used to collect experts' judgments on the desirability of a metric in respect to the innovativeness. When experts click the weblink for RI4, they are asked to provide their name. Instructions regarding the desirability function are provided on the web-page. Experts are asked to drag a point between 0 and 100 for each metric according to the desirability. The closer the bar to 100 , the more desirable the metric is. A small box to solicit the comments from experts is also provided.

The research instruments were tested and validated before being sent to Expert Panels 1, 2, and 3. The validation of the instruments is discussed in Chapter 6. 


\subsection{SUMMARY OF DATA COLLECTION PROCESS}

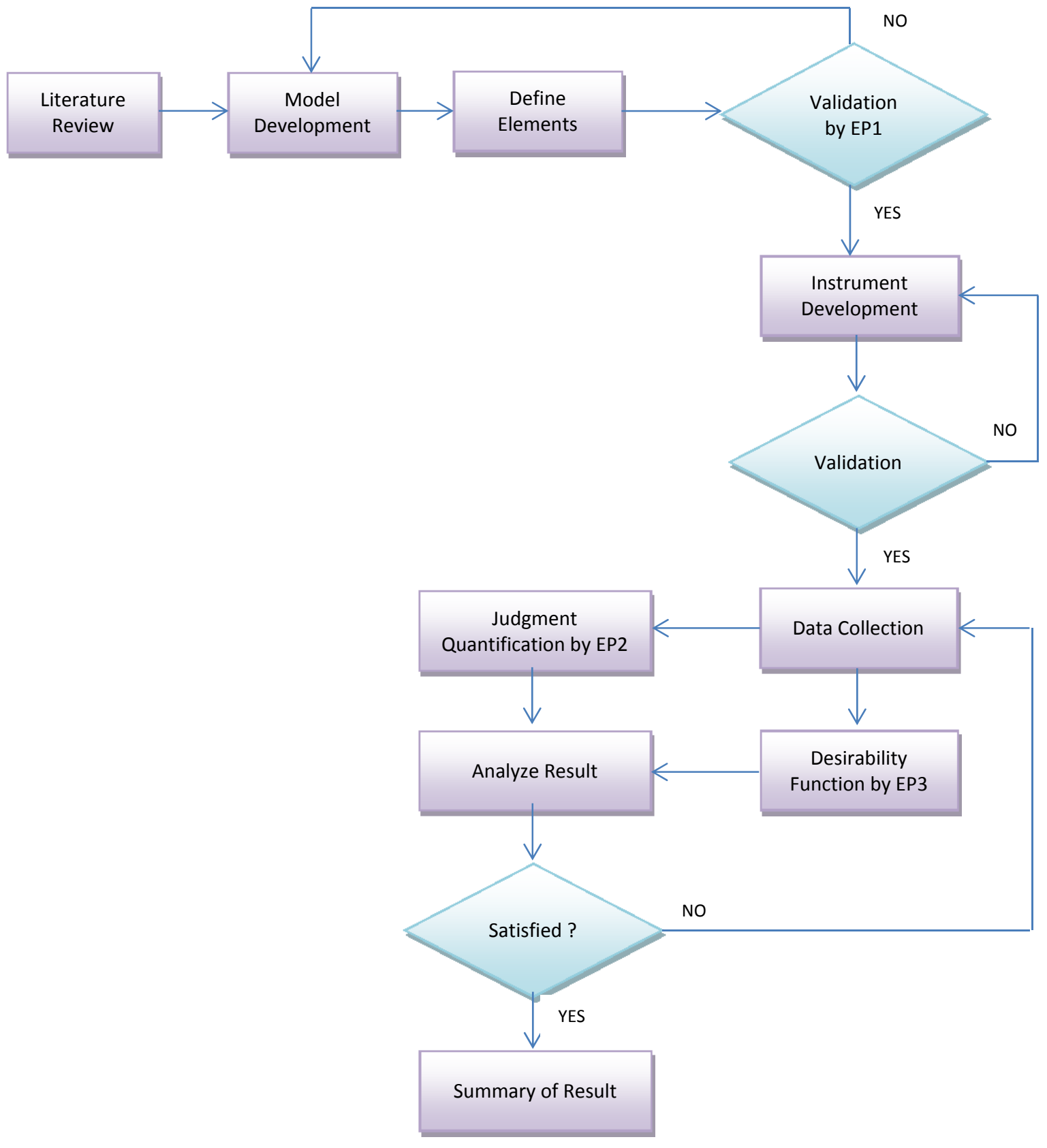

Figure 5.2 Data Collection Process 
This chapter discusses the results from three expert panels and provides in-depth analysis of the results.

\subsection{EXPERT PANEL 1}

\subsubsection{Expert Panel 1 Results}

Expert panel 1 was asked to identify output indicators to assess the innovativeness of a company in the semiconductor industry. There were 30 experts in expert panel 1. Output indicators identified from literature research were presented to the experts. Experts were given the options to choose whether those indicators should be included in the model/framework. Figure 6.1 shows output indicators that were approved by the experts to be included in the framework.

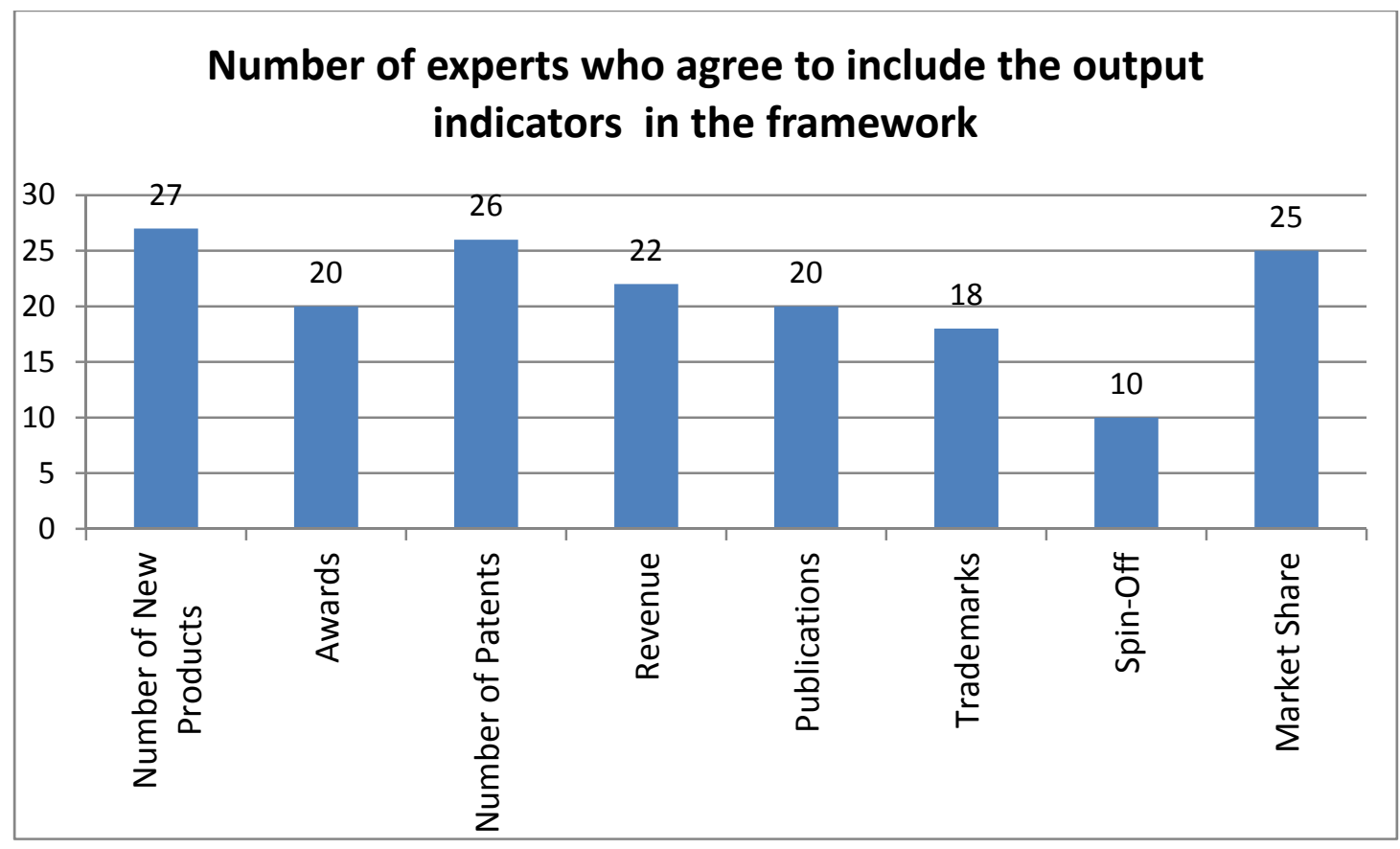

Figure 6.1 Number of experts who agree to include the output indicators in the framework 
In order for an indicator to be included in the model/framework, at least two thirds of the experts on expert panel 1 had to agree on it. There are 30 experts on expert panel 1 , which means that at least 20 of the experts had to agree on an output indicator to be included in the framework. Based on Figure 6.1, number of new products, number of patents, market share revenue, awards and publications received 27, 26, 25, 22, 20, and 20 votes respectively. Those output indicators are included in the framework. Meanwhile, trademarks and spin-off only received 18 and 10 votes respectively. Because both indicators did not receive at least two thirds of the experts' votes, they were excluded from the framework.

\subsection{EXPERT PANEL 2}

\subsubsection{Expert Panel 2 Results}

\subsubsection{Output Indicators}

There are six output indicators in the model to assess the innovativeness of a company in the semiconductor industry based on the inputs from expert panel 1. Expert panel 2, which consists of 36 experts, was asked to give their judgment quantifications on those output indicators. Each expert was asked to compare two output indicators at a time regarding their relative importance to the innovativeness of a company. Those six output indicators are number of new products, number of innovation awards, number of patents, revenue from new products, number of publications, and market share. Based on 32 experts, the arithmetic means of the relative importance of the output indicators is shown in Figure 6.2. 


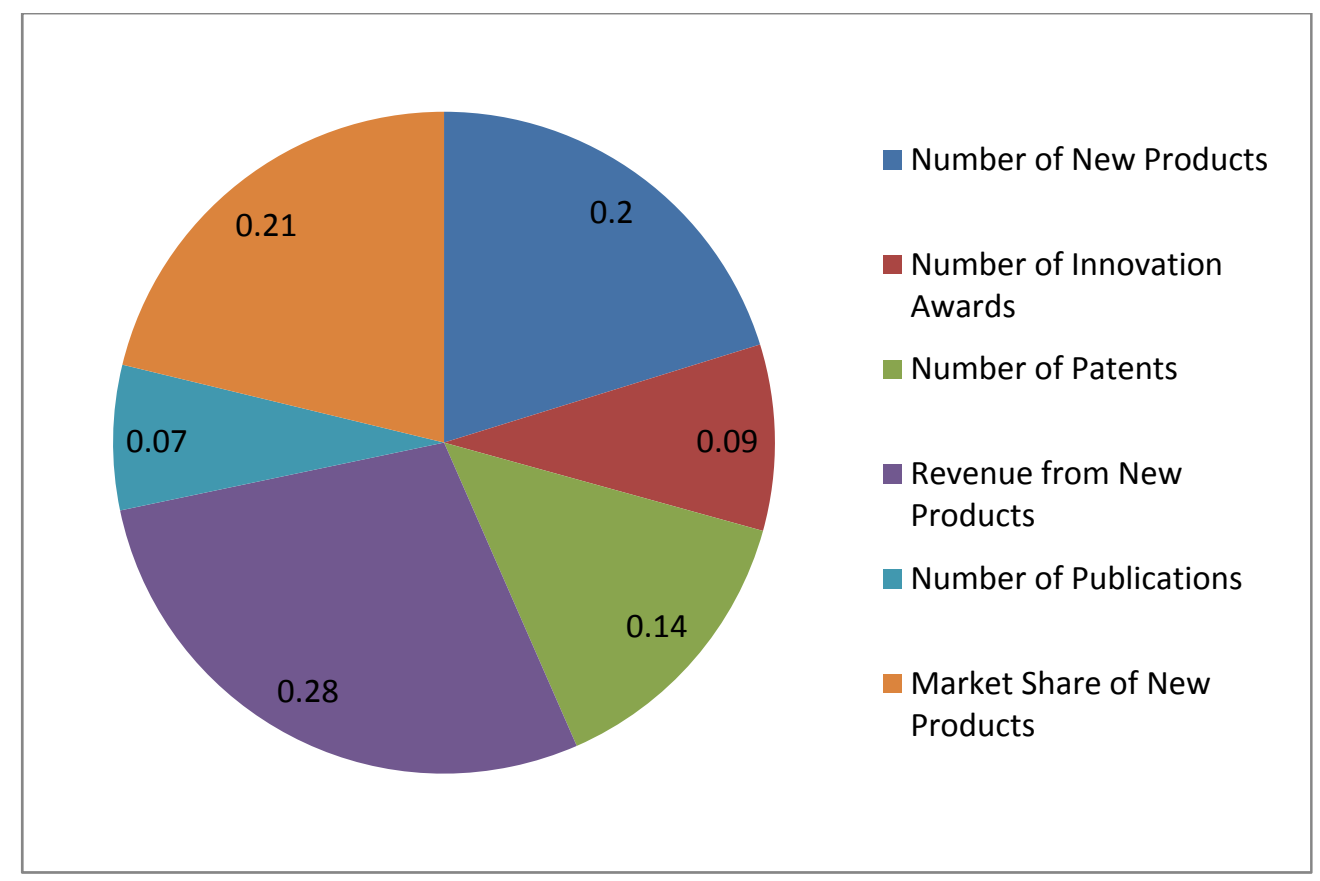

Figure 6.2 Relative Importance of the Output Indicators

According to the experts' judgments, revenue from new products has the highest priority of $26 \%$. Experts specify that revenue from new products is the best indicator to assess the innovativeness of a company among all. The second priority is market share of new products with $21 \%$. Third place to sixth place is number of new products, number of patents, number of innovation awards and number of publication with $20 \%, 14 \%, 9 \%$ and $7 \%$ respectively.

\subsubsection{Sub-factors}

Expert Panel 2 was also asked to give judgment quantifications on the sub-factors in terms of their relative importance to the output indicators. The results of the judgment quantifications of the sub-factors are presented in Figure 6.3 to Figure 6.6. 


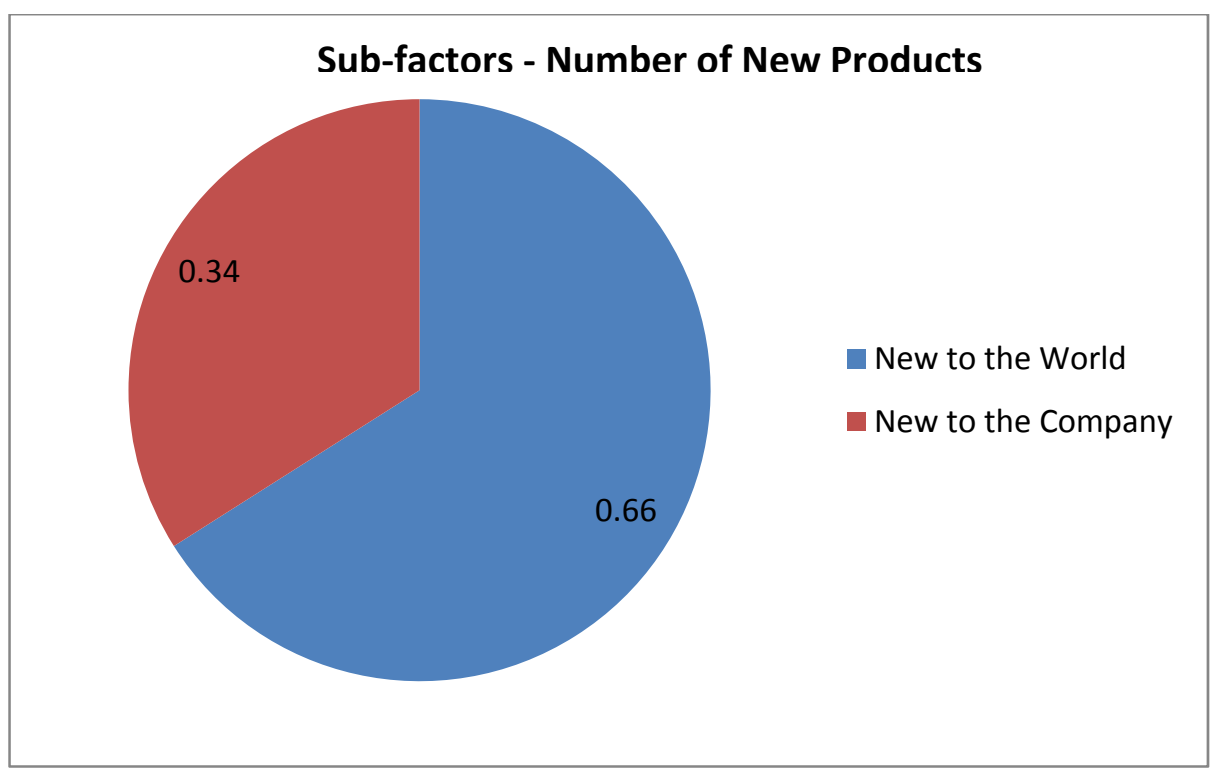

Figure 6.3 Relative Importance of Sub-Factors to Number of New Products

There are two sub-factors under number of new products. They are new products new to the world and new products new to the company. According to the experts, the number of new products new to the world is more important than new products new to the company with $66 \%$. New products new to the company received $34 \%$.

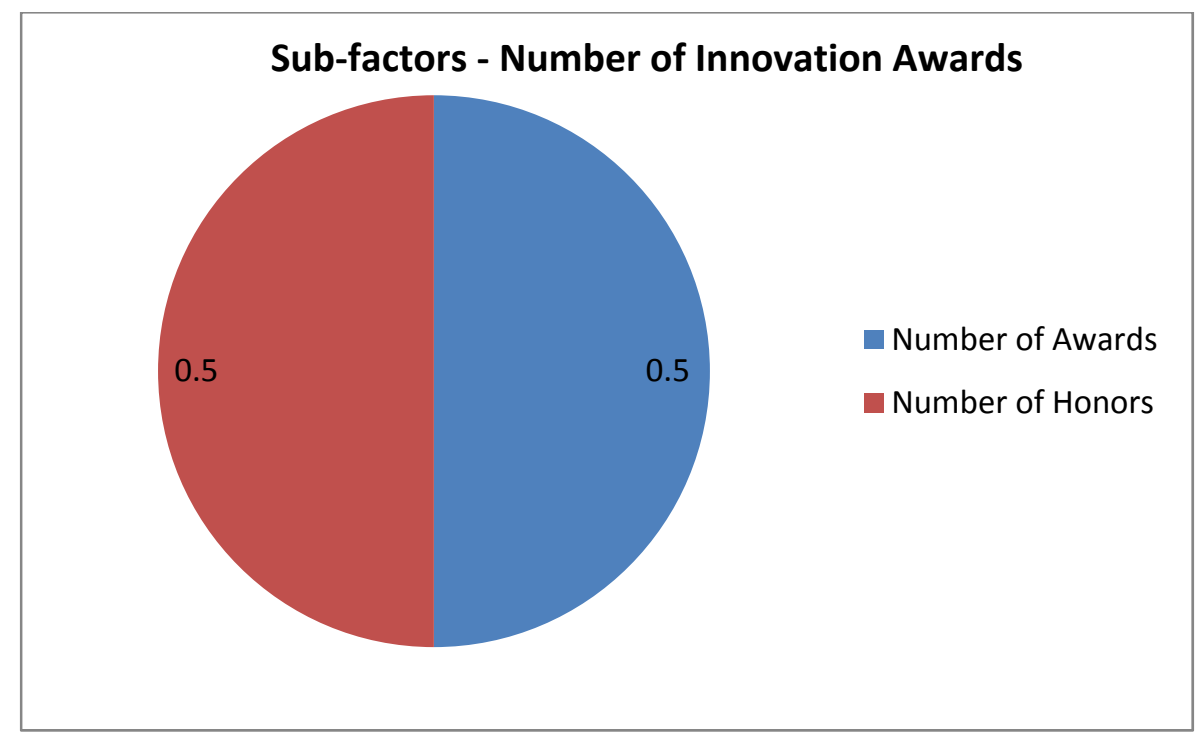

Figure 6.4 Relative Importance of Sub-factors to Number of Innovation Awards 
Number of awards and number of honors are the two sub-factors comprising the number of innovation awards. According to the experts, both sub-factors are equally important, with an average of $50 \%$ for each sub-factor.

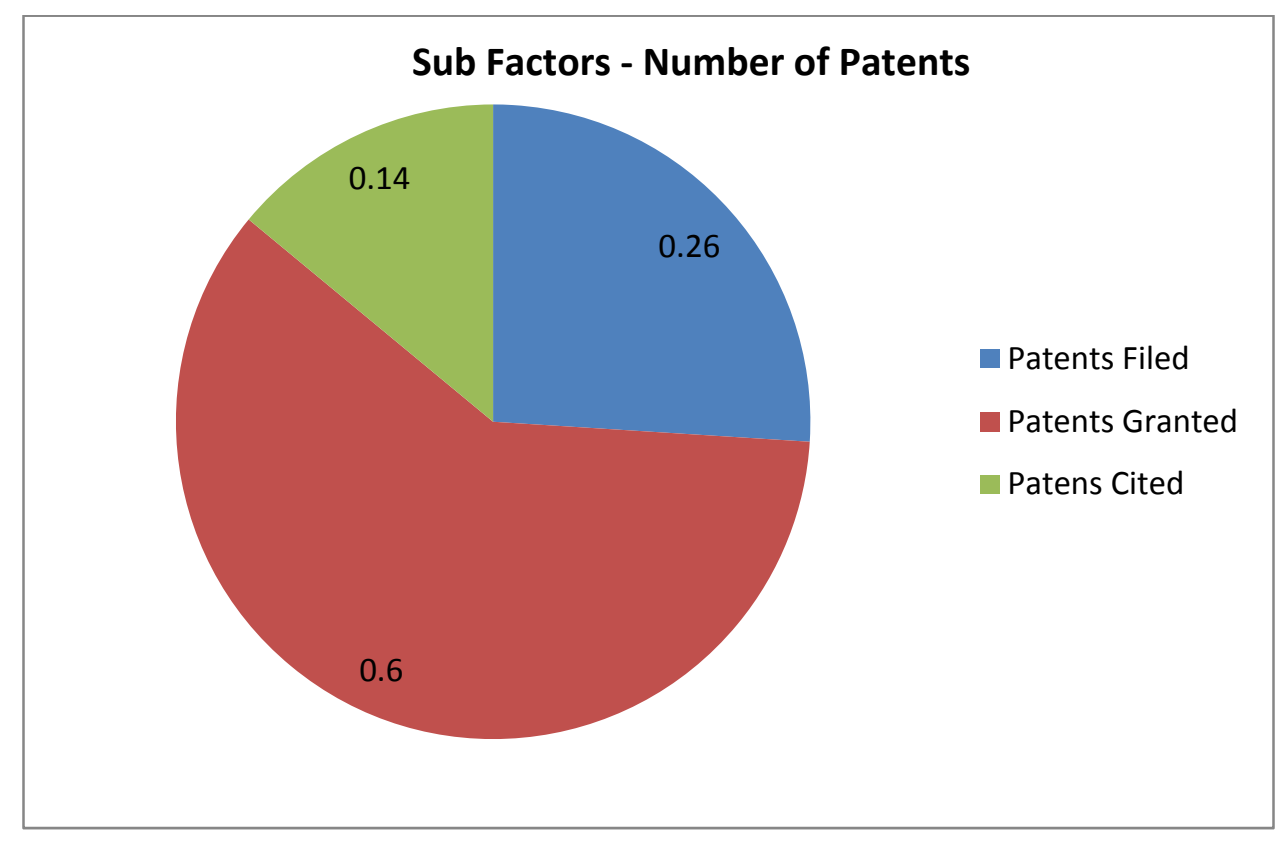

Figure 6.5 Relative Importance of Sub-factors to Number of Patents

There are three sub-factors under number of patents. They are number of patents filed, number of patents granted, and number of patents cited. According to the experts, number of patents granted has the highest importance with $60 \%$. Number of patents filed and number of patents cited ranked second and third with the percentage of $26 \%$ and $14 \%$ respectively. 


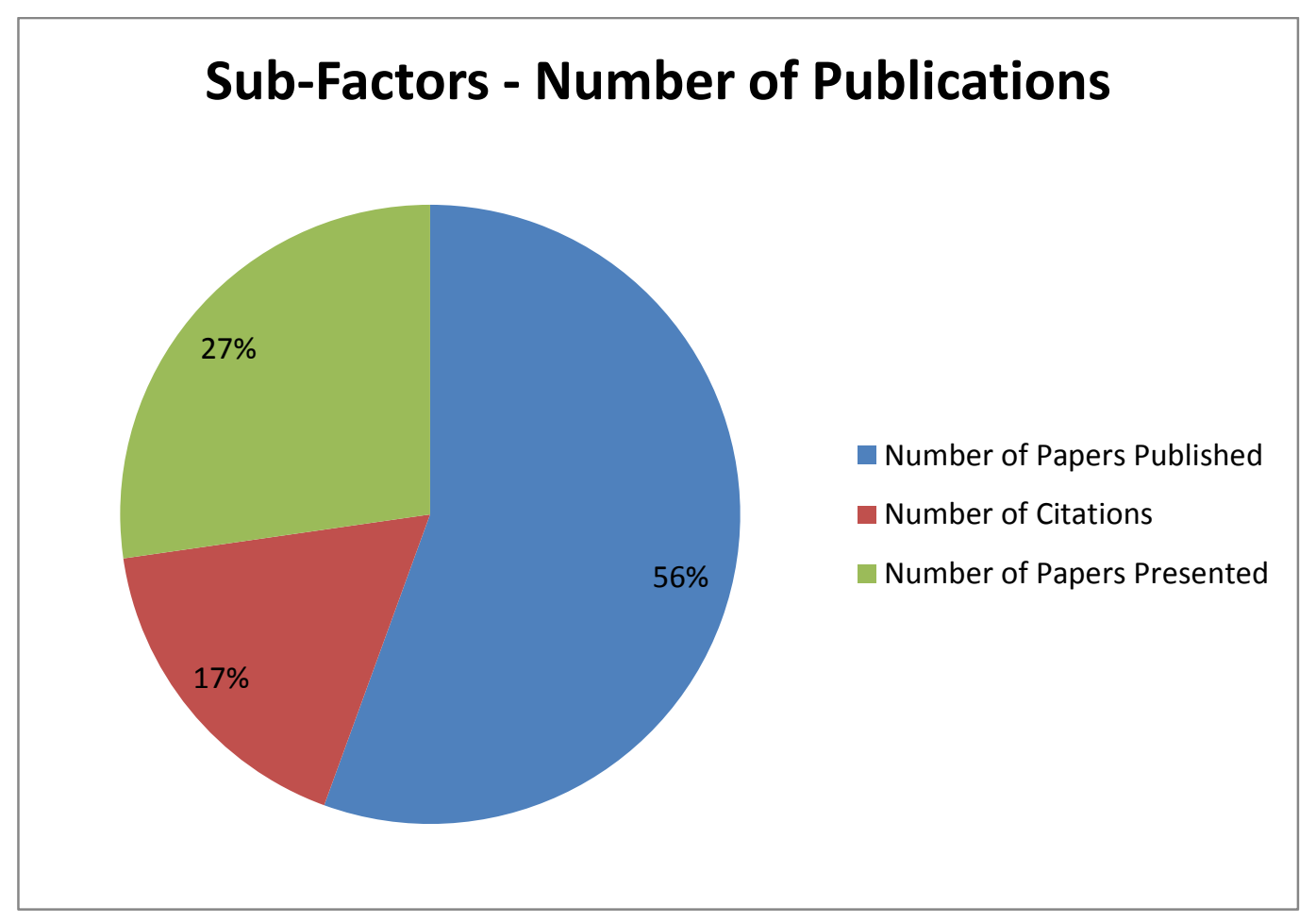

Figure 6.6 Relative Importance of Sub-factors to Number of Publications

Number of papers published in scientific publications, number of citations and number of papers presented are sub-factors of number of publications. According to the experts, the highest priority is number of papers published in scientific publications with $55 \%$. Number of papers presented is in second priority with $27 \%$, followed by number of citations with $18 \%$.

\subsubsection{Analysis of Expert Panel 2 Results}

\subsubsection{Analysis of Output Indicators}

The Individual result of the relative importance and the mean of 36 experts from expert panel 2 are presented in Table 6.1. 
TABLE 6.1 THE RELATIVE IMPORTANCE AND INCONSISTENCY OF OUTPUT INDICATORS FROM 36 EXPERTS IN EXPERT PANEL 2

\begin{tabular}{|c|c|c|c|c|c|c|c|}
\hline 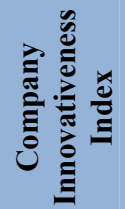 & 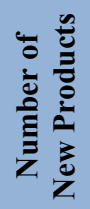 & 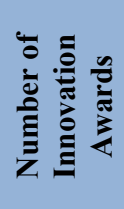 & 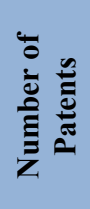 & 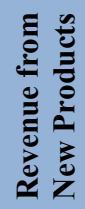 & 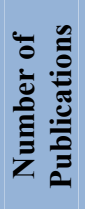 & 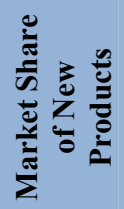 & 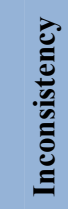 \\
\hline EXP1 & 0.16 & 0.05 & 0.06 & 0.34 & 0.05 & 0.34 & 0.07 \\
\hline EXP2 & 0.16 & 0.02 & 0.16 & 0.27 & 0.11 & 0.27 & 0.25 \\
\hline EXP3 & 0.21 & 0.09 & 0.12 & 0.27 & 0.07 & 0.24 & 0.06 \\
\hline EXP4 & 0.15 & 0.14 & 0.19 & 0.25 & 0.11 & 0.15 & 0.08 \\
\hline EXP5 & 0.26 & 0.05 & 0.1 & 0.36 & 0.05 & 0.18 & 0.05 \\
\hline EXP6 & 0.2 & 0.15 & 0.15 & 0.19 & 0.05 & 0.26 & 0.02 \\
\hline EXP7 & 0.21 & 0.06 & 0.09 & 0.37 & 0.05 & 0.21 & 0.03 \\
\hline EXP8 & 0.4 & 0.02 & 0.09 & 0.23 & 0.04 & 0.22 & 0.1 \\
\hline EXP9 & 0.25 & 0.03 & 0.14 & 0.33 & 0.04 & 0.21 & 0.02 \\
\hline EXP10 & 0.31 & 0.12 & 0.14 & 0.16 & 0.15 & 0.13 & 0.17 \\
\hline EXP11 & 0.19 & 0.02 & 0.36 & 0.21 & 0.03 & 0.19 & 0.11 \\
\hline EXP12 & 0.54 & 0.06 & 0.08 & 0.2 & 0.06 & 0.07 & 0.06 \\
\hline EXP13 & 0.42 & 0.09 & 0.14 & 0.18 & 0.08 & 0.09 & 0.03 \\
\hline EXP14 & 0.13 & 0.05 & 0.04 & 0.25 & 0.1 & 0.43 & 0.07 \\
\hline EXP15 & 0.43 & 0.04 & 0.05 & 0.35 & 0.02 & 0.1 & 0.06 \\
\hline EXP16 & 0.14 & 0.23 & 0.2 & 0.21 & 0.11 & 0.11 & 0.02 \\
\hline EXP17 & 0.16 & 0.07 & 0.12 & 0.33 & 0.09 & 0.23 & 0.02 \\
\hline EXP18 & 0.17 & 0.03 & 0.36 & 0.13 & 0.08 & 0.23 & 0.07 \\
\hline EXP19 & 0.19 & 0.12 & 0.08 & 0.37 & 0.06 & 0.18 & 0.03 \\
\hline EXP20 & 0.09 & 0.11 & 0.1 & 0.32 & 0.09 & 0.29 & 0.06 \\
\hline EXP21 & 0.09 & 0.12 & 0.2 & 0.34 & 0.05 & 0.19 & 0.06 \\
\hline EXP22 & 0.17 & 0.15 & 0.16 & 0.21 & 0.15 & 0.17 & 0.01 \\
\hline EXP23 & 0.2 & 0.11 & 0.1 & 0.34 & 0.1 & 0.15 & 0.04 \\
\hline EXP24 & 0.04 & 0.14 & 0.09 & 0.31 & 0.04 & 0.38 & 0.13 \\
\hline
\end{tabular}




\begin{tabular}{|c|c|c|c|c|c|c|c|} 
EXP25 & 0.1 & 0.14 & 0.23 & 0.22 & 0.08 & 0.22 & 0.01 \\
\hline EXP26 & 0.18 & 0.07 & 0.08 & 0.29 & 0.07 & 0.31 & 0.03 \\
\hline EXP27 & 0.16 & 0.14 & 0.22 & 0.09 & 0.06 & 0.33 & 0.05 \\
\hline EXP28 & 0.23 & 0.1 & 0.27 & 0.17 & 0.12 & 0.11 & 0.02 \\
\hline EXP29 & 0.04 & 0.17 & 0.08 & 0.43 & 0.02 & 0.27 & 0.11 \\
\hline EXP30 & 0.16 & 0.04 & 0.17 & 0.34 & 0.03 & 0.26 & 0.04 \\
\hline EXP31 & 0.23 & 0.05 & 0.08 & 0.41 & 0.06 & 0.18 & 0.04 \\
\hline EXP32 & 0.03 & 0.05 & 0.09 & 0.44 & 0.02 & 0.37 & 0.11 \\
\hline EXP33 & 0.21 & 0.1 & 0.09 & 0.38 & 0.07 & 0.15 & 0.06 \\
\hline EXP34 & 0.23 & 0.06 & 0.11 & 0.38 & 0.05 & 0.18 & 0.03 \\
\hline EXP35 & 0.22 & 0.12 & 0.15 & 0.23 & 0.12 & 0.15 & 0.01 \\
\hline EXP36 & 0.06 & 0.25 & 0.12 & 0.33 & 0.08 & 0.17 & 0.08 \\
\hline Mean & $\mathbf{0 . 2}$ & $\mathbf{0 . 0 9}$ & $\mathbf{0 . 1 4}$ & $\mathbf{0 . 2 8}$ & $\mathbf{0 . 0 7}$ & $\mathbf{0 . 2 1}$ & \\
\hline Disagreement & & & & & & & $\mathbf{0 . 0 7}$ \\
\hline
\end{tabular}

The inconsistency level of each expert for the output indicators is satisfactory with only 1 expert exceeding far beyond the tolerable inconsistency level of 0.1 . Overall, the value of the disagreement among experts is acceptable with the disagreement value of 0.07, which is fairly low. The intraclass correlation coefficient for all experts is fairly high with the value of 0.542 (see Table 6.2). In conclusion, the aggregate results from the experts are acceptable based on the intraclass correlation, inconsistency, and disagreement value. 
TABLE 6.2 INTRACLASS CORRELATION COEFFICIENT OF OUTPUT INDICATORS FROM

EXPERT PANEL 2

Intraclass Correlation Coefficient

\begin{tabular}{|l|r|r|r|r|r|r|r|}
\hline & \multirow{2}{*}{$\begin{array}{c}\text { Intraclass } \\
\text { Correlation }\end{array}$} & \multicolumn{3}{|c|}{ b9\% Confidence Interval } & \multicolumn{4}{|c|}{ F Test with True Value 0 } \\
\cline { 3 - 9 } & Lower Bound & Upper Bound & Value & df1 & df2 & Sig \\
\hline Single Measures & $.542^{\mathrm{a}}$ & .258 & .916 & 37.895 & 6 & 210 & .000 \\
Average Measures & .977 & .926 & .997 & 37.895 & 6 & 210 & .000 \\
\hline
\end{tabular}

Two-way random effects model where both people effects and measures effects are random.

a. The estimator is the same, whether the interaction effect is present or not.

b. Type A intraclass correlation coefficients using an absolute agreement definition.

Analysis was performed to find experts who have similar opinions regarding the relative importance of output indicators. From the pattern of the results, the experts can be clustered into four subgroups.

The $1^{\text {st }}$ subgroup consists of EXP 1 -5, EXP 7-9, EXPT 15-17, EXPT 19-23, EXP 25, EXP 29-36. There are a total of 25 experts in the $1^{\text {st }}$ subgroup. There is no specific characterization of the $1^{\text {st }}$ subgroup. These 25 experts agreed that revenue from new products is the most important output indicator. Based on their backgrounds, these experts are from industry, academia and government agencies. After the grouping, the disagreement level decreased to 0.06 for the $1^{\text {st }}$ subgroup (see Table 6.3). The intraclass correlation coefficient in the $1^{\text {st }}$ group is slightly higher than the intraclass correlation coefficient of all experts combined. The intraclass correlation coefficient for the $1^{\text {st }}$ subgroup is 0.685 as shown in Table 6.4 . 
TABLE 6.3 THE RELATIVE IMPORTANCE AND INCONSISTENCY OF OUTPUT INDICATORS FROM THE 1ST SUBGROUP

\begin{tabular}{|c|c|c|c|c|c|c|c|}
\hline 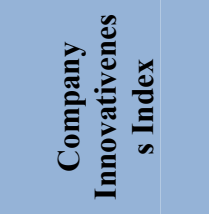 & 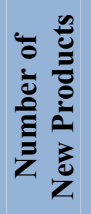 & 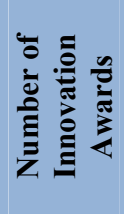 & 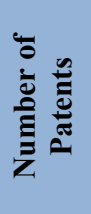 & 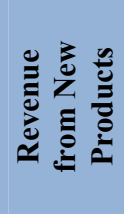 & 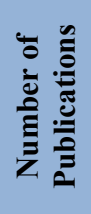 & 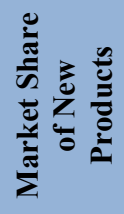 & 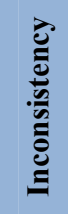 \\
\hline EXP1 & 0.16 & 0.05 & 0.06 & 0.34 & 0.05 & 0.34 & 0.07 \\
\hline EXP2 & 0.16 & 0.02 & 0.16 & 0.27 & 0.11 & 0.27 & 0.25 \\
\hline EXP3 & 0.21 & 0.09 & 0.12 & 0.27 & 0.07 & 0.24 & 0.06 \\
\hline EXP4 & 0.15 & 0.14 & 0.19 & 0.25 & 0.11 & 0.15 & 0.08 \\
\hline EXP7 & 0.21 & 0.06 & 0.09 & 0.37 & 0.05 & 0.21 & 0.03 \\
\hline EXP8 & 0.4 & 0.02 & 0.09 & 0.23 & 0.04 & 0.22 & 0.1 \\
\hline EXP9 & 0.25 & 0.03 & 0.14 & 0.33 & 0.04 & 0.21 & 0.02 \\
\hline EXP15 & 0.43 & 0.04 & 0.05 & 0.35 & 0.02 & 0.1 & 0.06 \\
\hline EXP16 & 0.14 & 0.23 & 0.2 & 0.21 & 0.11 & 0.11 & 0.02 \\
\hline EXP17 & 0.16 & 0.07 & 0.12 & 0.33 & 0.09 & 0.23 & 0.02 \\
\hline EXP19 & 0.19 & 0.12 & 0.08 & 0.37 & 0.06 & 0.18 & 0.03 \\
\hline EXP20 & 0.09 & 0.11 & 0.1 & 0.32 & 0.09 & 0.29 & 0.06 \\
\hline EXP21 & 0.09 & 0.12 & 0.2 & 0.34 & 0.05 & 0.19 & 0.06 \\
\hline EXP22 & 0.17 & 0.15 & 0.16 & 0.21 & 0.15 & 0.17 & 0.01 \\
\hline EXP23 & 0.2 & 0.11 & 0.1 & 0.34 & 0.1 & 0.15 & 0.04 \\
\hline EXP25 & 0.1 & 0.14 & 0.23 & 0.22 & 0.08 & 0.22 & 0.01 \\
\hline EXP29 & 0.04 & 0.17 & 0.08 & 0.43 & 0.02 & 0.27 & 0.11 \\
\hline EXP30 & 0.16 & 0.04 & 0.17 & 0.34 & 0.03 & 0.26 & 0.04 \\
\hline EXP31 & 0.23 & 0.05 & 0.08 & 0.41 & 0.06 & 0.18 & 0.04 \\
\hline EXP32 & 0.03 & 0.05 & 0.09 & 0.44 & 0.02 & 0.37 & 0.11 \\
\hline EXP33 & 0.21 & 0.1 & 0.09 & 0.38 & 0.07 & 0.15 & 0.06 \\
\hline EXP34 & 0.23 & 0.06 & 0.11 & 0.38 & 0.05 & 0.18 & 0.03 \\
\hline EXP35 & 0.22 & 0.12 & 0.15 & 0.23 & 0.12 & 0.15 & 0.01 \\
\hline EXP36 & 0.06 & 0.25 & 0.12 & 0.33 & 0.08 & 0.17 & 0.08 \\
\hline Mean & 0.18 & 0.1 & 0.12 & 0.32 & 0.07 & 0.21 & \\
\hline Disagreement & & & & & & & 0.06 \\
\hline
\end{tabular}

TABLE 6.4 INTRACLASS CORRELATION COEFFICIENT OF OUTPUT INDICATORS FROM THE 1ST SUBGROUP

Intraclass Correlation Coefficient

\begin{tabular}{|l|r|r|r|r|r|r|r|}
\hline & \multirow{2}{*}{$\begin{array}{c}\text { Intraclass } \\
\text { Correlation }\end{array}$} \\
\cline { 3 - 9 } & & \multicolumn{2}{|c|}{ Intraclass Correlation Coefficient } \\
\cline { 3 - 9 } & $.685^{\mathrm{a}}$ & .390 & \multicolumn{4}{|c|}{ F Test with True Value 0 } \\
\hline Single Measures & .982 & .941 & .952 & 48.225 & 6 & 144 & .000 \\
Average Measures & & .998 & 48.225 & 6 & 144 & .000 \\
\hline
\end{tabular}

Two-way random effects model where both people effects and measures effects are random.

a. The estimator is the same, whether the interaction effect is present or not.

b. Type A intraclass correlation coefficients using an absolute agreement definition. 
The $2^{\text {nd }}$ subgroup is comprised of EXP 6, EXP 14, EXP 24, EXP 26, and EXP 27, who agreed that market share is the best indicator to assess the innovativeness of a company in the semiconductor industry. Four out of five experts in this subgroup are from the industry sector. One of the experts is from the academic sector. The disagreement value of the $2^{\text {nd }}$ subgroup is lower than the overall disagreement of all experts. The disagreement value of the $2^{\text {nd }}$ subgroup is 0.059 (see Table 6.5). Similar with the $1^{\text {st }}$ subgroup, the intraclass correlation coefficient for the $2^{\text {nd }}$ subgroup is also higher than the intraclass correlation coefficient of all experts combined. The intraclass correlation coefficient for the $2^{\text {nd }}$ subgroup is 0.718 as shown in Table 6.6.

TABLE 6.5 THE RELATIVE IMPORTANCE AND INCONSISTENCY OF OUTPUT INDICATORS FROM THE 2ND SUBGROUP

\begin{tabular}{|c|c|c|c|c|c|c|c|}
\hline 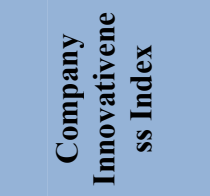 & 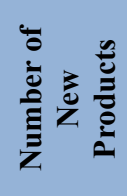 & 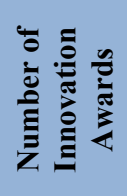 & 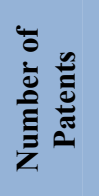 & 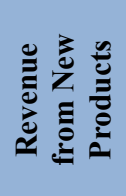 & 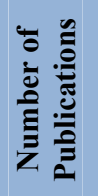 & 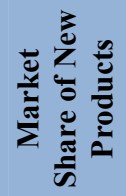 & 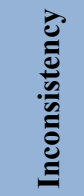 \\
\hline EXP6 & 0.2 & 0.15 & 0.15 & 0.19 & 0.05 & 0.26 & 0.02 \\
\hline EXP14 & 0.13 & 0.05 & 0.04 & 0.25 & 0.1 & 0.43 & 0.07 \\
\hline EXP24 & 0.04 & 0.14 & 0.09 & 0.31 & 0.04 & 0.38 & 0.13 \\
\hline EXP26 & 0.18 & 0.07 & 0.08 & 0.29 & 0.07 & 0.31 & 0.03 \\
\hline EXP27 & 0.16 & 0.14 & 0.22 & 0.09 & 0.06 & 0.33 & 0.05 \\
\hline Mean & 0.142 & 0.110 & 0.116 & 0.226 & 0.064 & 0.342 & \\
\hline Disagreement & & & & & & & 0.059 \\
\hline
\end{tabular}

TABLE 6.6 INTRACLASS CORRELATION COEFFICIENT OF OUTPUT INDICATORS FROM THE 2ND SUBGROUP

\begin{tabular}{|l|r|r|r|r|r|r|r|}
\hline \multirow{2}{*}{} & \multirow{2}{*}{$\begin{array}{c}\text { Intraclass } \\
\text { Correlation }^{\mathrm{b}}\end{array}$} & \multicolumn{2}{|c|}{$99 \%$ Confidence Interval } & \multicolumn{4}{|c|}{ F Test with True Value 0 } \\
\cline { 3 - 8 } & & Lower Bound & Upper Bound & Value & df1 & df2 & Sig \\
\hline Single Measures & $.718^{\mathrm{a}}$ & .303 & .963 & 12.040 & 6 & 24 & .000 \\
Average Measures & .927 & .685 & .992 & 12.040 & 6 & 24 & .000 \\
\hline
\end{tabular}

Two-way random effects model where both people effects and measures effects are random.

a. The estimator is the same, whether the interaction effect is present or not.

b. Type A intraclass correlation coefficients using an absolute agreement definition. 
The $3^{\text {rd }}$ subgroup, comprised of EXP 10, EXP 12 and EXP 13 who approved that number of new products, is the most important indicator to assess the innovativeness of a company in the semiconductor industry. Two of the experts are from the industry sector and one of the experts is from the academic sector. The value of the disagreement of the $3^{\text {rd }}$ subgroup is 0.046 (see Table 6.7). This disagreement value is lower than the disagreement value of all experts combined. It means that this grouping has a higher agreement among experts. The intraclass correlation coefficient for the third subgroup is also higher than the intraclass correlation coefficient for all experts combined. The value of the intraclass correlation of the $3^{\text {rd }}$ subgroup as shown in Table 6.8 is 0.797 .

\section{TABLE 6.7 THE RELATIVE IMPORTANCE AND INCONSISTENCY OF OUTPUT INDICATORS FROM THE $3^{\text {RD }}$ SUBGROUP}

\begin{tabular}{|c|c|c|c|c|c|c|c|}
\hline 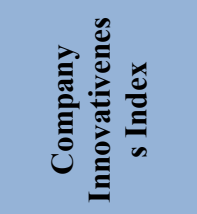 & 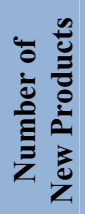 & 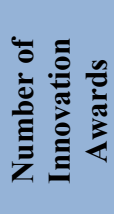 & 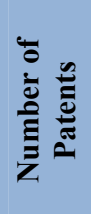 & 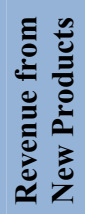 & 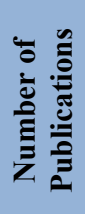 & 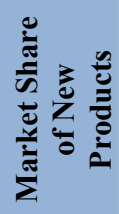 & 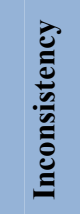 \\
\hline EXP10 & 0.31 & 0.12 & 0.14 & 0.16 & 0.15 & 0.13 & 0.17 \\
\hline EXP12 & 0.54 & 0.06 & 0.08 & 0.2 & 0.06 & 0.07 & 0.06 \\
\hline EXP13 & 0.42 & 0.09 & 0.14 & 0.18 & 0.08 & 0.09 & 0.03 \\
\hline Mean & 0.423 & 0.090 & 0.120 & 0.180 & 0.097 & 0.097 & \\
\hline Disagreement & & & & & & & 0.046 \\
\hline
\end{tabular}

TABLE 6.8 INTRACLASS CORRELATION COEFFICIENT OF OUTPUT INDICATORS FROM THE $3^{\mathrm{RD}}$ SUBGROUP

Intraclass Correlation Coefficient

\begin{tabular}{|l|r|r|r|r|r|r|r|}
\hline & \multirow{2}{*}{$\begin{array}{c}\text { Intraclass } \\
\text { Correlation }\end{array}$} & \multicolumn{2}{|c|}{$99 \%$ Confidence Interval } & \multicolumn{4}{|c|}{ F Test with True Value 0 } \\
\cline { 3 - 9 } & Lower Bound & Upper Bound & Value & df1 & df2 & Sig \\
\hline \multirow{2}{*}{ Single Measures } & $.797^{\mathrm{a}}$ & .285 & .977 & 11.445 & 6 & 12 & .000 \\
Average Measures & .922 & .544 & .992 & 11.445 & 6 & 12 & .000 \\
\hline
\end{tabular}

Two-way random effects model where both people effects and measures effects are random.

a. The estimator is the same, whether the interaction effect is present or not.

b. Type A intraclass correlation coefficients using an absolute agreement definition. 
The 4th subgroup consists of EXP 11, EXP 18, and EXP 28, who favored patents as the most important indicator to assess the innovativeness of a company in the semiconductor industry. Two out of three experts are from the academic sector and one of the experts is from the industry sector. Similar with the other three subgroups, the disagreement level in the $4^{\text {th }}$ group also decreased after the grouping. The value of the disagreement of the $4^{\text {th }}$ subgroup is 0.045 (see Table 6.9). The intraclass correlation coefficient for the $4^{\text {th }}$ subgroup is also significantly higher compared to the intraclass correlation coefficient of all experts combined. The value of the intraclass correlation coefficient of the $4^{\text {th }}$ subgroup is 0.806 as shown in Table 6.10 .

TABLE 6.9 THE RELATIVE IMPORTANCE AND INCONSISTENCY OF OUTPUT INDICATORS FROM THE $4^{\mathrm{TH}}$ SUBGROUP

\begin{tabular}{|c|c|c|c|c|c|c|c|}
\hline 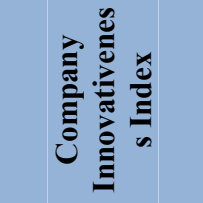 & 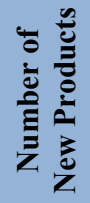 & 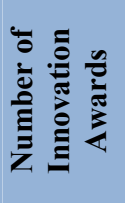 & 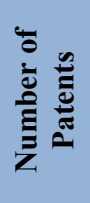 & 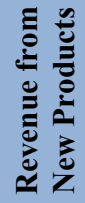 & 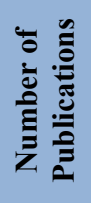 & 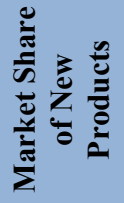 & 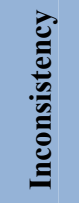 \\
\hline EXP11 & 0.19 & 0.02 & 0.36 & 0.21 & 0.03 & 0.19 & 0.11 \\
\hline EXP18 & 0.17 & 0.03 & 0.36 & 0.13 & 0.08 & 0.23 & 0.02 \\
\hline EXP28 & 0.23 & 0.1 & 0.27 & 0.17 & 0.12 & 0.11 & 0.05 \\
\hline Mean & 0.197 & 0.050 & 0.330 & 0.170 & 0.077 & 0.177 & \\
\hline Disagreement & & & & & & & 0.045 \\
\hline
\end{tabular}

TABLE 6.10 INTRACLASS CORRELATION COEFFICIENT OF OUTPUT INDICATORS FROM THE $4^{\mathrm{TH}}$ SUBGROUP

\begin{tabular}{|c|c|c|c|c|c|c|c|}
\hline \multicolumn{8}{|c|}{ Intraclass Correlation Coefficient } \\
\hline & \multirow{2}{*}{$\begin{array}{c}\text { Intraclass } \\
\text { Correlation }^{\mathrm{b}}\end{array}$} & \multicolumn{2}{|c|}{$99 \%$ Confidence Interval } & \multicolumn{4}{|c|}{ F Test with True Value 0} \\
\hline & & Lower Bound & Upper Bound & Value & df1 & $\mathrm{df} 2$ & Sig \\
\hline Single Measures & $.806^{\mathrm{a}}$ & .297 & .978 & 11.877 & 6 & 12 & .000 \\
\hline Average Measures & .926 & .559 & .993 & 11.877 & 6 & 12 & .000 \\
\hline
\end{tabular}

Two-way random effects model where both people effects and measures effects are random.

a. The estimator is the same, whether the interaction effect is present or not.

b. Type A intraclass correlation coefficients using an absolute agreement definition. 
After the clustering of the experts in expert panel 2, the disagreement level decreased, which means that the agreement of the experts in each subgroup is improved compared to the agreement of all experts combined into one panel. The intraclass correlation coefficient of the subgroups also increases after the clustering. Table 6.11 shows the comparison of relative priorities, disagreement value and intraclass coefficient correlation of the experts before and after the clustering.

TABLE 6.11 COMPARISONS OF RELATIVE IMPORTANCE, DISAGREEMENT, AND INTRACLASS CORRELATION BEFORE AND AFTER CLUSTERING

\begin{tabular}{|c|c|c|c|c|c|c|c|c|}
\hline & 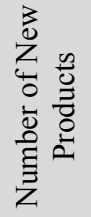 & 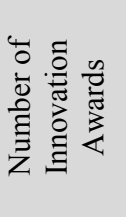 & 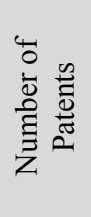 & 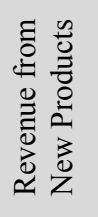 & 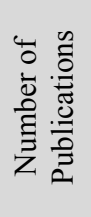 & 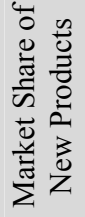 & 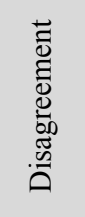 & 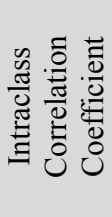 \\
\hline 36 Experts & 0.198 & 0.093 & 0.139 & 0.284 & 0.071 & 0.214 & 0.075 & 0.542 \\
\hline $1^{\text {st }}$ Subgroup & 0.182 & 0.096 & 0.123 & 0.322 & 0.069 & 0.208 & 0.062 & 0.685 \\
\hline $2^{\text {nd }}$ Subgroup & 0.142 & 0.110 & 0.116 & 0.226 & 0.064 & 0.342 & 0.059 & 0.718 \\
\hline $3^{\text {rd }}$ Subgroup & 0.423 & 0.09 & 0.12 & 0.18 & 0.097 & 0.097 & 0.046 & 0.797 \\
\hline $4^{\text {th }}$ Subgroup & 0.197 & 0.05 & 0.33 & 0.17 & 0.077 & 0.177 & 0.045 & 0.806 \\
\hline
\end{tabular}

Taking the relative importance of all experts into account, the highest importance is revenue from new products. The second priority is market share of new products, followed by number of new products, number of patents, number of innovation awards and number of publications respectively.

After the categorization, the $1^{\text {st }}$ subgroup has the same relative priorities of the output indicators. The most important output indicators in the $1^{\text {st }}$ subgroup is revenue from new products, followed by market share of new products, number of new products, number of patents, number of innovation awards and number of publications.

The $2^{\text {nd }}$ subgroup is almost identical with the $1^{\text {st }}$ subgroup except for the first and the second ranking of the output indicators. The $1^{\text {st }}$ ranking of the $2^{\text {nd }}$ subgroup is market 
share of new products, followed by revenue from new products, number of new products, number of patents, number of innovation awards and number of publications.

The $3^{\text {rd }}$ subgroup is slightly different from the $1^{\text {st }}$ and $2^{\text {nd }}$ subgroup. The highest importance in the $3^{\text {rd }}$ subgroup is number of new products. The second ranking is revenue from new products. The third to sixth ranking is number of patents, market share of new products, number of publications and number of innovation awards respectively.

The last subgroup heavily emphasizes the number of patents as it received the highest ranking among all subgroups. The second raking is given to number of new products. Revenue from new products and market share of new products have the same importance from the $4^{\text {th }}$ subgroup. Number of publications and number of innovation awards are in $5^{\text {th }}$ and $6^{\text {th }}$ places respectively.

Even though there are slight changes in the rankings after the categorization, overall the rankings of the output indicators are fairly consistent because the disagreement among experts is relatively low.

\subsubsection{Analysis of Sub-factors}

\subsection{Number of New Products}

There are two sub-factors under number of new products, e.g., number of new products new to the world and number of new products new to the company. Experts from academia, industry, and government were asked to give their judgment quantifications on those output indicators. Table 6.12 presents the results from 35 experts. 
TABLE 6.12 THE RELATIVE IMPORTANCE AND INCONSISTENCY OF SUB-FACTORS OF NUMBER OF NEW PRODUCTS FROM EXPERT PANEL 2

\begin{tabular}{|c|c|c|c|}
\hline $\begin{array}{c}\text { Number of New } \\
\text { Products }\end{array}$ & New to the World & $\begin{array}{l}\text { New to the } \\
\text { Company }\end{array}$ & Inconsistency \\
\hline EXP1 & 0.7 & 0.3 & 0 \\
\hline EXP2 & 0.7 & 0.3 & 0 \\
\hline EXP3 & 0.68 & 0.32 & 0 \\
\hline EXP4 & 0.7 & 0.3 & 0 \\
\hline EXP5 & 0.6 & 0.4 & 0 \\
\hline EXP6 & 0.6 & 0.4 & 0 \\
\hline EXP7 & 0.67 & 0.33 & 0 \\
\hline EXP8 & 0.65 & 0.35 & 0 \\
\hline EXP9 & 0.7 & 0.3 & 0 \\
\hline EXP10 & 0.65 & 0.35 & 0 \\
\hline EXP11 & 0.75 & 0.25 & 0 \\
\hline EXP12 & 0.5 & 0.5 & 0 \\
\hline EXP13 & 0.65 & 0.35 & 0 \\
\hline EXP14 & 0.75 & 0.25 & 0 \\
\hline EXP15 & 0.6 & 0.4 & 0 \\
\hline EXP16 & 0.55 & 0.45 & 0 \\
\hline EXP17 & 0.6 & 0.4 & 0 \\
\hline EXP18 & 0.7 & 0.3 & 0 \\
\hline EXP19 & 0.65 & 0.35 & 0 \\
\hline EXP20 & 0.6 & 0.4 & 0 \\
\hline EXP21 & 0.7 & 0.3 & 0 \\
\hline EXP22 & 0.75 & 0.25 & 0 \\
\hline EXP23 & 0.65 & 0.35 & 0 \\
\hline EXP24 & 0.6 & 0.4 & 0 \\
\hline EXP25 & 0.6 & 0.4 & 0 \\
\hline EXP26 & 0.65 & 0.35 & 0 \\
\hline EXP27 & 0.7 & 0.3 & 0 \\
\hline EXP28 & 0.65 & 0.35 & 0 \\
\hline EXP29 & 0.75 & 0.25 & 0 \\
\hline EXP30 & 0.68 & 0.32 & 0 \\
\hline EXP31 & 0.8 & 0.2 & 0 \\
\hline EXP32 & 0.6 & 0.4 & 0 \\
\hline EXP33 & 0.7 & 0.3 & 0 \\
\hline EXP34 & 0.65 & 0.35 & 0 \\
\hline EXP35 & 0.7 & 0.3 & 0 \\
\hline Mean & 0.66 & 0.34 & \\
\hline Disagreement & & & 0.06 \\
\hline
\end{tabular}


Because there are only two sub-factors to evaluate, the inconsistency of the experts is zero. Almost all experts agreed that number of new products new to the world is more important than number of new products new to the company. The disagreement level is 0.06 . Additional analysis was performed to test the intraclass correlation coefficient of the sub-factors of number of new products. As seen in Table 6.13, the intraclass correlation is very high with a value of 0.93 , which is close to 1 .

\section{TABLE 6.13 INTRACLASS CORRELATION COEFFICIENT OF SUB-FACTORS OF NUMBER OF} NEW PRODUCTS

Intraclass Correlation Coefficient

\begin{tabular}{|l|r|r|r|r|r|r|r|}
\hline & \multirow{2}{*}{$\begin{array}{c}\text { Intraclass } \\
\text { Correlation }\end{array}$} & \multicolumn{3}{|c|}{$99 \%$ Confidence Interval } & \multicolumn{4}{|c|}{ F Test with True Value 0 } \\
\cline { 3 - 9 } & & Lower Bound & Upper Bound & Value & df1 & df2 & Sig \\
\hline Single Measures & $.930^{\mathrm{a}}$ & .587 & 1.000 & 233.159 & 1 & 34 & .000 \\
Average Measures & .998 & .980 & 1.000 & 233.159 & 1 & 34 & .000 \\
\hline
\end{tabular}

Two-way random effects model where both people effects and measures effects are random.

a. The estimator is the same, whether the interaction effect is present or not.

b. Type A intraclass correlation coefficients using an absolute agreement definition.

\subsection{Number of Innovation Awards}

Two sub-factors are part of this output indicator: number of awards and number of honors. The results of the pairwise comparison for number of innovation awards are presented in Table 6.14. 
TABLE 6.14 THE RELATIVE IMPORTANCE AND INCONSISTENCY OF SUB -FACTORS OF NUMBER OF INNOVATION AWARDS FROM EXPERT PANEL 2

\begin{tabular}{|c|c|c|c|}
\hline $\begin{array}{c}\text { Number of Innovation } \\
\text { Awards } \\
\end{array}$ & Number of Awards & Number of Honors & Inconsistency \\
\hline EXP1 & 0.5 & 0.5 & 0 \\
\hline EXP2 & 0.5 & 0.5 & 0 \\
\hline EXP3 & 0.5 & 0.5 & 0 \\
\hline EXP4 & 0.55 & 0.45 & 0 \\
\hline EXP5 & 0.5 & 0.5 & 0 \\
\hline EXP6 & 0.5 & 0.5 & 0 \\
\hline EXP7 & 0.5 & 0.5 & 0 \\
\hline EXP8 & 0.5 & 0.5 & 0 \\
\hline EXP9 & 0.5 & 0.5 & 0 \\
\hline EXP10 & 0.5 & 0.5 & 0 \\
\hline EXP11 & 0.5 & 0.5 & 0 \\
\hline EXP12 & 0.5 & 0.5 & 0 \\
\hline EXP13 & 0.5 & 0.5 & 0 \\
\hline EXP14 & 0.5 & 0.5 & 0 \\
\hline EXP15 & 0.5 & 0.5 & 0 \\
\hline EXP16 & 0.5 & 0.5 & 0 \\
\hline EXP17 & 0.5 & 0.5 & 0 \\
\hline EXP18 & 0.5 & 0.5 & 0 \\
\hline EXP19 & 0.5 & 0.5 & 0 \\
\hline EXP20 & 0.5 & 0.5 & 0 \\
\hline EXP21 & 0.5 & 0.5 & 0 \\
\hline EXP22 & 0.6 & 0.4 & 0 \\
\hline EXP23 & 0.5 & 0.5 & 0 \\
\hline EXP24 & 0.5 & 0.5 & 0 \\
\hline EXP25 & 0.5 & 0.5 & 0 \\
\hline EXP26 & 0.5 & 0.5 & 0 \\
\hline EXP27 & 0.5 & 0.5 & 0 \\
\hline EXP28 & 0.5 & 0.5 & 0 \\
\hline EXP29 & 0.45 & 0.55 & 0 \\
\hline EXP30 & 0.5 & 0.5 & 0 \\
\hline EXP31 & 0.5 & 0.5 & 0 \\
\hline EXP32 & 0.5 & 0.5 & 0 \\
\hline EXP33 & 0.55 & 0.45 & 0 \\
\hline EXP34 & 0.5 & 0.5 & 0 \\
\hline EXP35 & 0.5 & 0.5 & 0 \\
\hline Mean & 0.5 & 0.5 & \\
\hline Disagreement & & & 0.02 \\
\hline
\end{tabular}


Almost all the experts from academia, industry and government agreed that number of awards and number of honors have the same relative importance to assess the innovativeness of a company. Because the proportion is so close to each other, it brings the mean of both sub-factors to equally 0.5 . The inconsistency is zero since there are only two items to compare and the disagreement level is 0.02 . Since all experts distributed the relative importance almost equally to both sub-factors, there is no need to perform an intraclass correlation. The numbers have shown that there is almost an absolute agreement about the sub-factors of number of innovation awards.

\subsection{Number of Patents}

There are three sub-factors under number of patents: number of patents filed, number of patents granted, and number of patents cited. The relative importance of the sub-factors is presented in Table 6.15 .

TABLE 6.15 THE RELATIVE IMPORTANCE AND INCONSISTENCY OF SUB-FACTORS OF NUMBER OF PATENTS FROM EXPERT PANEL 2

\begin{tabular}{|c|c|c|c|c|}
\hline Number of Patents & $\begin{array}{c}\text { Number of } \\
\text { Patents Filed }\end{array}$ & $\begin{array}{c}\text { Numbers of Patents } \\
\text { Granted }\end{array}$ & $\begin{array}{c}\text { Number of Patents } \\
\text { Cited }\end{array}$ & Inconsistency \\
\hline EXP1 & 0.24 & 0.67 & 0.09 & 0 \\
\hline EXP2 & 0.24 & 0.64 & 0.12 & 0 \\
\hline EXP3 & 0.27 & 0.6 & 0.09 & 0 \\
\hline EXP4 & 0.24 & 0.67 & 0.11 & 0 \\
\hline EXP5 & 0.23 & 0.66 & 0.1 & 0 \\
\hline EXP6 & 0.24 & 0.66 & 0.1 & 0 \\
\hline EXP7 & 0.28 & 0.62 & 0.12 & 0 \\
\hline EXP8 & 0.23 & 0.64 & 0.12 & 0 \\
\hline
\end{tabular}




\begin{tabular}{|c|c|c|c|c|}
\hline EXP9 & 0.27 & 0.59 & 0.14 & 0 \\
\hline EXP10 & 0.26 & 0.6 & 0.14 & 0.01 \\
\hline EXP11 & 0.28 & 0.59 & 0.13 & 0.07 \\
\hline EXP12 & 0.26 & 0.62 & 0.11 & 0 \\
\hline EXP13 & 0.28 & 0.54 & 0.18 & 0 \\
\hline EXP14 & 0.27 & 0.56 & 0.17 & 0 \\
\hline EXP15 & 0.15 & 0.81 & 0.04 & 0.03 \\
\hline EXP16 & 0.29 & 0.51 & 0.2 & 0 \\
\hline EXP17 & 0.27 & 0.56 & 0.17 & 0 \\
\hline EXP18 & 0.21 & 0.67 & 0.12 & 0 \\
\hline EXP19 & 0.26 & 0.62 & 0.11 & 0 \\
\hline EXP20 & 0.32 & 0.58 & 0.1 & 0 \\
\hline EXP21 & 0.26 & 0.54 & 0.2 & 0 \\
\hline EXP22 & 0.25 & 0.62 & 0.13 & 0 \\
\hline EXP23 & 0.26 & 0.56 & 0.18 & 0 \\
\hline EXP24 & 0.29 & 0.53 & 0.18 & 0.01 \\
\hline EXP25 & 0.27 & 0.57 & 0.16 & 0 \\
\hline EXP26 & 0.26 & 0.57 & 0.18 & 0 \\
\hline EXP27 & 0.18 & 0.57 & 0.26 & 0 \\
\hline EXP28 & 0.3 & 0.47 & 0.23 & 0 \\
\hline EXP29 & 0.3 & 0.53 & 0.17 & 0.02 \\
\hline EXP30 & 0.26 & 0.63 & 0.11 & 0.01 \\
\hline EXP31 & 0.27 & 0.56 & 0.17 & 0 \\
\hline EXP32 & 0.25 & 0.62 & 0.14 & 0 \\
\hline EXP33 & 0.21 & 0.68 & 0.11 & 0 \\
\hline EXP34 & 0.25 & 0.62 & 0.13 & 0.01 \\
\hline EXP35 & 0.31 & 0.51 & 0.18 & 0 \\
\hline Mean & 0.26 & 0.6 & 0.14 & \\
\hline Disagreement & & & & 0.05 \\
\hline
\end{tabular}


The inconsistencies of the experts for sub-factors under the number of patents are low. Most of the experts have the inconsistency of zero. Some of them have a slight inconsistency, which is still below the acceptable inconsistency level of 0.1 . The disagreement among all experts is quite low with the value of 0.05 .

Almost all experts agreed that number of patents granted is the most important sub-factor under number of patents. According to the experts, if the patents are not innovative or novel, they won't be granted. Thus, number of patents granted receives the highest value among all. The second priority is number of patents filed. Only companies that come up with new ideas will have new patents to file. Thus, this is the second most important sub-factor. The third priority is the number of patents cited. Experts expressed that patents cited would give information on how valuable a patent is. The more it is cited, the more the value is. The intraclass correlation coefficient of the experts is very high with the value of 0.959 , which is close to 1 . Table 6.16 below presents the intraclass correlation coefficient of the relative importance of sub-factors under number of patents.

TABLE 6.16 INTRACLASS CORRELATION COEFFICIENT OF SUB-FACTORS OF NUMBER OF PATENTS

Intraclass Correlation Coefficient

\begin{tabular}{|l|r|r|r|r|r|r|r|}
\hline \multirow{2}{*}{} & \multirow{2}{*}{$\begin{array}{c}\text { Intraclass } \\
\text { Correlation }\end{array}$} & \multicolumn{3}{|c|}{$99 \%$ Confidence Interval } & \multicolumn{4}{|c|}{ F Test with True Value 0 } \\
\cline { 3 - 9 } & Lower Bound & Upper Bound & Value & df1 & df2 & Sig \\
\hline \multirow{2}{*}{ Single Measures } & $.959^{\mathrm{a}}$ & .802 & 1.000 & 547.156 & 2 & 68 & .000 \\
Average Measures & .999 & .993 & 1.000 & 547.156 & 2 & 68 & .000 \\
\hline
\end{tabular}

Two-way random effects model where both people effects and measures effects are random.

a. The estimator is the same, whether the interaction effect is present or not.

b. Type A intraclass correlation coefficients using an absolute agreement definition. 


\subsection{Number of Publications}

There are three sub-factors under the number of publications: number of papers in scientific publications, number of citations and number of papers presented. Table 6.17 shows the results from the experts.

TABLE 6.17 THE RELATIVE IMPORTANCE AND INCONSISTENCY OF SUB-FACTORS OF NUMBER OF PUBLICATIONS FROM EXPERT PANEL 2

\begin{tabular}{|c|c|c|c|c|}
\hline $\begin{array}{l}\text { Number of } \\
\text { Patents }\end{array}$ & $\begin{array}{c}\text { Number of Papers in Scientific } \\
\text { Publications }\end{array}$ & $\begin{array}{l}\text { Number of } \\
\text { Citations }\end{array}$ & $\begin{array}{c}\text { Number of } \\
\text { Papers } \\
\text { Presented }\end{array}$ & Inconsistency \\
\hline EXP1 & 0.53 & 0.14 & 0.33 & 0 \\
\hline EXP2 & 0.34 & 0.15 & 0.51 & 0 \\
\hline EXP3 & 0.59 & 0.16 & 0.25 & 0 \\
\hline EXP4 & 0.62 & 0.13 & 0.25 & 0 \\
\hline EXP5 & 0.38 & 0.16 & 0.46 & 0.02 \\
\hline EXP6 & 0.64 & 0.15 & 0.21 & 0.07 \\
\hline EXP7 & 0.57 & 0.17 & 0.27 & 0.01 \\
\hline EXP8 & 0.52 & 0.15 & 0.32 & 0 \\
\hline EXP9 & 0.58 & 0.14 & 0.28 & 0 \\
\hline EXP10 & 0.75 & 0.03 & 0.21 & 0.1 \\
\hline EXP11 & 0.58 & 0.13 & 0.29 & 0 \\
\hline EXP12 & 0.64 & 0.1 & 0.26 & 0.05 \\
\hline EXP13 & 0.56 & 0.17 & 0.27 & 0 \\
\hline EXP14 & 0.57 & 0.18 & 0.26 & 0 \\
\hline EXP15 & 0.66 & 0.15 & 0.19 & 0 \\
\hline EXP16 & 0.48 & 0.31 & 0.21 & 0 \\
\hline EXP17 & 0.56 & 0.15 & 0.29 & 0.01 \\
\hline EXP18 & 0.5 & 0.23 & 0.27 & 0 \\
\hline EXP19 & 0.54 & 0.18 & 0.28 & 0 \\
\hline EXP20 & 0.55 & 0.18 & 0.27 & 0.04 \\
\hline EXP21 & 0.51 & 0.22 & 0.27 & 0.01 \\
\hline EXP22 & 0.54 & 0.17 & 0.29 & 0 \\
\hline EXP23 & 0.61 & 0.16 & 0.23 & 0.02 \\
\hline EXP24 & 0.57 & 0.16 & 0.27 & 0.01 \\
\hline EXP25 & 0.64 & 0.12 & 0.24 & 0 \\
\hline EXP26 & 0.53 & 0.17 & 0.3 & 0.02 \\
\hline EXP27 & 0.54 & 0.26 & 0.2 & 0 \\
\hline EXP28 & 0.52 & 0.24 & 0.24 & 0.01 \\
\hline
\end{tabular}




\begin{tabular}{|c|c|c|c|c|} 
EXP29 & 0.5 & 0.17 & 0.33 & 0.02 \\
\hline EXP30 & 0.54 & 0.2 & 0.27 & 0 \\
\hline EXP31 & 0.53 & 0.28 & 0.19 & 0.01 \\
\hline EXP32 & 0.58 & 0.16 & 0.26 & 0 \\
\hline EXP33 & 0.59 & 0.19 & 0.22 & 0.02 \\
\hline EXP34 & 0.45 & 0.3 & 0.25 & 0 \\
\hline EXP35 & 0.56 & 0.26 & 0.18 & 0 \\
\hline Mean & $\mathbf{0 . 5 5}$ & $\mathbf{0 . 1 7}$ & $\mathbf{0 . 2 7}$ & \\
\hline Disagreement & & & & $\mathbf{0 . 0 5}$ \\
\hline
\end{tabular}

Almost all experts gave the highest priority to the number of papers in scientific publications. A publication in a scientific journal indicates that a company has some research ideas, which, according to the experts, will lead to innovativeness. The second priority is the number of papers presented. The third priority is number of citations. According to the experts, number of citations does not necessarily indicate the innovativeness of a company. It shows the quality of the paper. The disagreement value of all experts is 0.05 , which is fairly low. The inconsistency is also acceptable with no experts exceeding the value of 0.1 . The intraclass correlation coefficient value is very high with the value of 0.897 , as presented in Table 6.18 .

\section{TABLE 6.18 INTRACLASS CORRELATION COEFFICIENT OF SUB-FACTORS OF NUMBER OF} NEW PUBLICATIONS

\begin{tabular}{|l|r|r|r|r|r|r|r|}
\hline \multicolumn{1}{|c|}{ Intraclass Correlation Coefficient } \\
\cline { 3 - 9 } & \multirow{2}{*}{$\begin{array}{c}\text { Intraclass } \\
\text { Correlation }\end{array}$} & \multicolumn{2}{|c|}{$99 \%$ Confidence Interval } & \multicolumn{4}{|c|}{ F Test with True Value 0 } \\
\cline { 3 - 9 } & & Lower Bound & Upper Bound & Value & df1 & df2 & Sig \\
\hline Single Measures & $.897^{\mathrm{a}}$ & .596 & .999 & 203.440 & 2 & 68 & .000 \\
Average Measures & .997 & .981 & 1.000 & 203.440 & 2 & 68 & .000 \\
\hline
\end{tabular}

Two-way random effects model where both people effects and measures effects are random.

a. The estimator is the same, whether the interaction effect is present or not.

b. Type A intraclass correlation coefficients using an absolute agreement definition. 


\subsubsection{Validation of Data - Expert Panel 2}

\subsubsection{Output Indicators}

\subsection{Comparative Judgment and Quantification of Output Indicators from Expert}

Panel 2.

The inconsistency level of the 36 experts who provided their judgment quantifications is highly acceptable, except for one expert with a fairly high inconsistency level of 0.25 . Four experts also exceeded the tolerable level of inconsistency, but could be ignored since the value is close to 0.1 . The majority of the experts have a level of inconsistency that falls below 0.1 , indicating that the relative priorities of the experts are reliable.

\subsection{Agreement of Output Indicators from Expert Panel 2.}

To test the disagreement among experts, the following hypotheses were developed:

$\mathrm{H}_{0}: \mathrm{r}_{\mathrm{ic}}=0$ there is disagreement

$\mathrm{H}_{\mathrm{a}}: \mathrm{r}_{\mathrm{ic}}>0$ there is statistically significant evidence that there is some level of agreement

\section{$\underline{\text { All } 36 \text { Experts }}$}

The intraclass correlation was calculated to find out the level of agreement among the group of experts. From the calculation, the intraclass correlation coefficient of output indicators is 0.542 . The value is considered fairy high (on a scale of 0 to 1 ). From the value it is concluded that there is somewhat of a level of agreement among those experts. 
In addition to the intraclass correlation coefficient, F-test was also performed to test the group agreement. The calculation to find the computed F-value is needed. After the computed F-value is obtained, it is compared to F-critical. To test the agreement among experts with high reliability, the F-critical is placed at the 0.01 level. The computed F-value from 36 experts is 37.895 . The F-critical at the 0.01 level is 2.89 . Since the computed F-value is significantly higher than F-critical, the null hypothesis can be rejected. The F-test confirmed that there is no statistically significant difference among the experts in expert panel two regarding output indicators.

\section{The $1^{\text {st }}$ Subgroup}

The grouping was performed based on the results. After the grouping, the intraclass correlation coefficient of the $1^{\text {st }}$ subgroup is increased to 0.685 . The computed F-value of the first subgroup is 48.225 , while the F-critical at 0.01 is 2.9296 . Because the computed F-value is higher than F-critical, the null hypothesis can be rejected. The F-test shows that there is no statistically significant difference among the experts in the $1^{\text {st }}$ subgroup.

\section{The 2nd Subgroup}

The $2^{\text {nd }}$ subgroup also shows a higher intraclass correlation coefficient after the grouping with the value of 0.718 . The computed F-value of the $2^{\text {nd }}$ subgroup is 12.04 , while the F-critical at 0.01 is 3.6667 . Because the compute F-value is higher than Fcritical, the null hypothesis can be rejected. It means that there is no statistically significant difference among experts in the $2^{\text {nd }}$ subgroup. 


\section{The 3rd Subgroup}

The value of the intraclass correlation coefficient of the $3^{\text {rd }}$ subgroup is increased to 0.797 . The computed F-value for the $3^{\text {rd }}$ subgroup is 11.445 . The F-critical at 0.01 is 4.8206. The null hypothesis is rejected because the computed F-value is higher than Fcritical. It also indicates that there is no statistically significant difference among experts in the $3^{\text {rd }}$ subgroup.

\section{The 4th Subgroup}

The intraclass correlation coefficient value for the $4^{\text {th }}$ subgroup is 0.806 . It is close to 1 , which means that the experts have a high agreement with each other. The computed F-value for the $4^{\text {th }}$ subgroup is 11.877 . The F-critical at 0.01 is 4.8206 . Because the computed F-value is higher than F-critical, the null hypothesis is rejected, which means that there is no statistically significant difference among experts in the $4^{\text {th }}$ subgroup.

\subsubsection{Sub Factors}

\subsection{Comparative Judgment and Quantification of Output Indicators from Expert}

Panel 2.

Since there are only two elements to compare at a time, the inconsistency for number of new products and number of innovation awards is zero. The number of patents indicator has three sub-factors. The inconsistency level is almost non-existent for a majority of the experts. Some experts have inconsistency with a very low value ranging from $0.01-0.07$. It does not exceed the upper limit of 0.1 for the inconsistency level. 
Number of publications has three sub-factors as well. Unlike number of patents indicators, numbers of publications sub-factors have a different range of inconsistency from 0.01 to 0.1 . Most of the experts, if not all, have the inconsistency below 0.1 . From the analysis above, the reliability of the relative importance for the sub-factors is acceptable.

\subsection{Agreement of Sub-factors from Expert Panel 2.}

Similar with output indicators, to test the disagreement among experts regarding sub-factors, the following hypotheses were developed:

$\mathrm{H}_{0}: \mathrm{r}_{\mathrm{ic}}=0$ there is disagreement

$\mathrm{H}_{\mathrm{a}}: \mathrm{r}_{\mathrm{ic}}>0$ there is statistically significant evidence that there is some level of agreement

\section{$\underline{\text { Number of New Products }}$}

The intraclass correlation coefficient for two sub-factors under number of new products is 0.93 . The intraclass correlation coefficient is very high with the value quite close to 1 . The computed F-value for these sub-factors is 233.159. The F-critical at 0.01 is 7.4441. Because the F-critical is lower than the computed F value, the null hypothesis is rejected. It means that there is no statistically significant difference among experts in expert panel 2 regarding sub-factors of number of new products.

\section{$\underline{\text { Number of Patents }}$}

There are three sub-factors under number of new products. Based on the experts' judgments, the intraclass correlation is very high with the value of 0.959 . The computed 
F-value is 547.156 , while the F-critical at 0.01 is 4.9316 . The null hypothesis is rejected because the computed F-value is enormously higher than F-critical. It shows that there is no statistically significant difference among experts regarding sub-factors of number of patents.

\section{Number of Publications}

Similar with number of patents, there are also three sub-factors under number of publications. The intraclass correlation coefficient is 0.897 . The computed F-value is 203.440. The F-critical at 0.01 is 4.9316 . Since the computed F value is higher than Fcritical, the null hypothesis can be rejected. It means that there is no statistically significant difference among experts in panel 2 regarding the sub-factors of number of publications.

\subsubsection{Synthesis of Priorities}

Syntheses of priorities are done by multiplying the relative contribution of subfactors with the relative priorities of output indicators. The mean values of sub-factors and output indicators from all experts were used since there is no statistically significant difference among them. The results of the syntheses are presented in Table 6.19. 
TABLE 6.19 THE RELATIVE CONTRIBUTION OF SUB-FACTORS TO THE INNOVATIVENESS

INDEX

\begin{tabular}{|l|c|l|c|c|}
\hline $\begin{array}{l}\text { Output } \\
\text { Indicators }\end{array}$ & Value & \multicolumn{2}{|c|}{ Sub-Factors } & $\begin{array}{c}\text { Sub-factors Value to the } \\
\text { Innovativeness Index }\end{array}$ \\
\hline $\begin{array}{l}\text { Number of New } \\
\text { Products }\end{array}$ & 0.2 & New to the World & 0.66 & 0.132 \\
\cline { 3 - 5 } & & $\begin{array}{l}\text { New to the } \\
\text { Company }\end{array}$ & 0.34 & 0.068 \\
\hline $\begin{array}{l}\text { Number of Innovation } \\
\text { Awards }\end{array}$ & 0.09 & Number of Awards & 0.5 & 0.045 \\
\cline { 3 - 5 } & & Number of Honors & 0.5 & 0.045 \\
\hline Number of Patents & 0.14 & Patents Granted & 0.6 & 0.084 \\
\cline { 3 - 5 } & & Patents Filed & 0.26 & 0.036 \\
\cline { 3 - 5 } & Patents Cited & 0.14 & 0.02 \\
\hline $\begin{array}{l}\text { Revenue From New } \\
\text { Products }\end{array}$ & 0.28 & $\begin{array}{l}\text { Revenue from New } \\
\text { Products }\end{array}$ & 1 & 0.28 \\
\hline $\begin{array}{l}\text { Number of } \\
\text { Publications }\end{array}$ & 0.07 & Papers Published & 0.55 & 0.039 \\
\cline { 3 - 5 } & & Papers Presented & 0.27 & 0.019 \\
\cline { 3 - 5 } & Papers Cited & 0.17 & 0.012 \\
\hline $\begin{array}{l}\text { Market Share of New } \\
\text { Products }\end{array}$ & 0.21 & $\begin{array}{l}\text { Market Share of } \\
\text { New Products }\end{array}$ & 1 & 0.21 \\
\hline Total & 1 & \multicolumn{2}{|l}{} \\
\hline
\end{tabular}

Table 6.19 shows the relative importance of the sub-factors with respect to the innovativeness index. Since revenue from new products and market share of new products do not have any sub-factors, the value of the sub-factor under them is assumed 1. After the calculation, revenue from new products, market share of new products, and number of new products new to the world are in the top 3 with relative contributions of $0.28,0.21$ and 0.132 respectively. The top 3 sub-factors are followed by number of patents granted $(0.084)$, number of new products that are new to the company $(0.068)$, number of awards (0.045), number of honors (0.045), number of paper published in scientific publications (0.039), number of patents filed (0.036), number of patents cited (0.02), number of papers presented (0.019), and number of papers cited (0.012).

As discussed earlier, the grouping of experts was performed to find experts who share the same point of view. Table 6.19 shows the synthesis of priorities of all 36 
experts. An analysis was done to see if the ranking of sub-factors would change if the experts were separated into different groups. Table 6.20 shows the ranking of the subfactors under different circumstances.

TABLE 6.20 THE RELATIVE CONTRIBUTION OF SUB-FACTORS TO THE INNOVATIVENESS INDEX FROM ALL EXPERTS AND FOUR SUB-GROUPS AND RANKING OF THE SUB-FACTORS

\begin{tabular}{|l|c|c|c|c|c|}
\hline Sub-Factors & 36 Experts & $1^{\text {st }}$ Sub-group & $2^{\text {nd }}$ Sub-group & $3^{\text {rd }}$ Sub-group & $4^{\text {th }}$ Sub-group \\
\hline New to the World & $0.13(3)$ & $0.12(3)$ & $0.09(3)$ & $0.28(1)$ & $0.13(4)$ \\
\hline New to the Company & $0.07(5)$ & $0.06(5)$ & $0.05(7)$ & $0.14(3)$ & $0.07(6)$ \\
\hline Number of Awards & $0.05(6)$ & $0.05(6)$ & $0.06(5)$ & $0.05(7)$ & $0.03(9)$ \\
\hline Number of Honors & $0.05(7)$ & $0.05(7)$ & $0.06(6)$ & $0.05(8)$ & $0.03(10)$ \\
\hline Patents Granted & $0.08(4)$ & $0.07(4)$ & $0.07(4)$ & $0.07(5)$ & $0.20(1)$ \\
\hline Patents Filed & $0.04(9)$ & $0.03(9)$ & $0.03(9)$ & $0.03(9)$ & $0.09(5)$ \\
\hline Patents Cited & $0.02(10)$ & $0.02(10)$ & $0.02(10)$ & $0.02(11)$ & $0.05(7)$ \\
\hline Revenue from New Products & $0.28(1)$ & $0.32(1)$ & $0.23(2)$ & $0.18(2)$ & $0.17(3)$ \\
\hline Papers Published & $0.04(8)$ & $0.04(8)$ & $0.04(8)$ & $0.06(6)$ & $0.04(8)$ \\
\hline Papers Presented & $0.02(11)$ & $0.02(11)$ & $0.02(11)$ & $0.03(10)$ & $0.02(11)$ \\
\hline Papers Cited & $0.01(12)$ & $0.01(12)$ & $0.01(12)$ & $0.02(12)$ & $0.01(12)$ \\
\hline Market Share of New Products & $0.21(2)$ & $0.21(2)$ & $0.34(1)$ & $0.10(4)$ & $0.18(2)$ \\
\hline
\end{tabular}

There are slight but insignificant changes in the rankings and relative contributions when the relative priorities from 4 different sub-groups are used. Revenue from new products, which was at the first ranking if we used the results from all experts, remains on the first ranking based on the results from the $1^{\text {st }}$ sub-groups. The ranking did not change drastically even though the other sub-groups did not rank revenue from new products as the first priority. Revenue from new products still remains in the top 3 to assess the innovativeness of a company.

Market share of new products and number of new products that are new to the world also have steady rankings, even though different groups gave different relative importance to these two indicators. Both remained in the top 4 in the different groups, however. 
The only major change in the ranking happened to number of patents granted. Based on the responses from the $4^{\text {th }}$ sub-group, who favor number of patents as the top indicator, number of patents granted jumped to the first ranking. In other sub-groups the ranking of patents granted was steady at the $4^{\text {th }}$ or $5^{\text {th }}$ ranking.

Number of new products new to the company, number of awards, number of honors, and number of papers presented are in the mid-range with a consistent ranking ranging from $5^{\text {th }}-8^{\text {th }}$. There is no surprise in these sub-factors.

Number of patents filed is always at the $9^{\text {th }}$ ranking except for the $4^{\text {th }}$ sub-group, which gave the number of patents as the most important indicator to assess the innovativeness of a company. In that case, number of patents filed rose to 5th place.

In all groups, number of patents filed, number of papers presented, and number of papers cited are considered the least important by all different groups. These sub-factors are placed at the bottom 3 ranking in almost all groups. It means that after the grouping, all experts still agree that these three sub-factors are the least important to assess the innovativeness of a company.

\subsection{EXPERT PANEL 3}

\subsubsection{Expert Panel 3 Results}

Experts in panel 3 were asked to provide the desirability values for each subfactor. The desirability value is given between $0-100$. Tables $6.21-6.32$ show the results of the desirability value for each sub-factor. 
Number of New Products New to the World

The metric for this variable is the number of new products developed by the company that are new to the world, as a percentage of the total number of products of the company in the last three years.

TABLE 6.21 DESIRABILITY VALUES - NUMBER OF NEW PRODUCTS NEW TO THE WORLD

\begin{tabular}{|c|c|c|c|c|c|c|}
\hline $\begin{array}{c}\text { Number of New Products New } \\
\text { to the World }\end{array}$ & $0 \%$ & $20 \%$ & $40 \%$ & $60 \%$ & $80 \%$ & $100 \%$ \\
\hline EXP1 & 20 & 50 & 60 & 70 & 40 & 20 \\
\hline EXP2 & 30 & 70 & 100 & 90 & 80 & 70 \\
\hline EXP3 & 15 & 40 & 60 & 90 & 40 & 0 \\
\hline EXP4 & 22 & 100 & 70 & 48 & 29 & 10 \\
\hline EXP5 & 10 & 40 & 50 & 80 & 40 & 20 \\
\hline Mean & 19.4 & 60 & 68 & 75.6 & 45.8 & 24 \\
\hline
\end{tabular}

Number of New Products that are New to the Company

The metric for this variable is the number of new products that are new to the company, as a percentage of the total number of products of the company in the last three years.

TABLE 6.22 DESIRABILITY VALUES - NUMBER OF NEW PRODUCTS NEW TO THE COMPANY

\begin{tabular}{|c|c|c|c|c|c|c|}
\hline $\begin{array}{c}\text { Number of New Products New } \\
\text { to the Company }\end{array}$ & $0 \%$ & $20 \%$ & $40 \%$ & $60 \%$ & $80 \%$ & $100 \%$ \\
\hline EXP1 & 20 & 40 & 50 & 70 & 60 & 20 \\
\hline EXP2 & 10 & 30 & 50 & 60 & 90 & 30 \\
\hline EXP3 & 10 & 40 & 90 & 50 & 60 & 0 \\
\hline EXP4 & 23 & 58 & 78 & 53 & 70 & 0 \\
\hline EXP5 & 20 & 30 & 50 & 60 & 40 & 20 \\
\hline Mean & 16.6 & 39.6 & 63.6 & 58.6 & 64 & 14 \\
\hline
\end{tabular}


Number of Innovation Awards

The metric for this variable is the ratio of number of innovation awards received by the company in the last three years to number of researchers in the company.

TABLE 6.23 DESIRABILITY VALUES - NUMBER OF INNOVATION AWARDS

\begin{tabular}{|c|c|c|c|c|c|c|}
\hline $\begin{array}{c}\text { Number of } \\
\text { Innovation } \\
\text { Awards }\end{array}$ & $\begin{array}{c}\text { More than 1 } \\
\text { Per } \\
\text { Researcher }\end{array}$ & $\begin{array}{c}1 \text { Award per } \\
1-10 \\
\text { Researchers }\end{array}$ & $\begin{array}{c}1 \text { Award per } \\
11-50 \\
\text { Researchers }\end{array}$ & $\begin{array}{c}1 \text { Award per } \\
51-100 \\
\text { Researchers }\end{array}$ & $\begin{array}{c}1 \text { Award per } \\
101-1000 \\
\text { Researchers }\end{array}$ & $\begin{array}{c}1 \text { Award per } \\
1000+ \\
\text { Researchers }\end{array}$ \\
\hline EXP1 & 9 & 27 & 42 & 57 & 73 & 93 \\
\hline EXP2 & 10 & 70 & 50 & 30 & 20 & 0 \\
\hline EXP3 & 20 & 30 & 50 & 70 & 40 & 10 \\
\hline EXP4 & 30 & 60 & 100 & 60 & 30 & 0 \\
\hline Mean & 17.25 & 46.75 & 60.5 & 54.25 & 40.75 & 25.75 \\
\hline
\end{tabular}

\section{Number of Innovation Honors}

The metric for this variable is the ratio of number of innovation honors received by the company in the last three years to number of researchers in the company.

TABLE 6.24 DESIRABILITY VALUES - NUMBER OF INNOVATION HONORS

\begin{tabular}{|c|c|c|c|c|c|c|}
\hline $\begin{array}{c}\text { Number of } \\
\text { Innovation } \\
\text { Awards }\end{array}$ & $\begin{array}{c}\text { More than 1 } \\
\text { Per } \\
\text { Researcher }\end{array}$ & $\begin{array}{c}1 \text { Award per } \\
1-10 \\
\text { Researchers }\end{array}$ & $\begin{array}{c}1 \text { Award per } \\
11-50 \\
\text { Researchers }\end{array}$ & $\begin{array}{c}1 \text { Award per } \\
51-100 \\
\text { Researchers }\end{array}$ & $\begin{array}{c}\text { 1 Award per } \\
101-1000 \\
\text { Researchers }\end{array}$ & $\begin{array}{c}1 \text { Award per } \\
1000+ \\
\text { Researchers }\end{array}$ \\
\hline EXP1 & 7 & 25 & 44 & 63 & 83 & 96 \\
\hline EXP2 & 20 & 50 & 43 & 48 & 31 & 5 \\
\hline EXP3 & 10 & 40 & 50 & 60 & 45 & 30 \\
\hline EXP4 & 30 & 50 & 70 & 60 & 60 & 0 \\
\hline Mean & 13.4 & 33 & 41.4 & 46.2 & 43.8 & 26.2 \\
\hline
\end{tabular}

\section{Number of Patents Filed}

The metric for this variable is the ratio of number of patents filed by the company in the last three years to number of researchers in the company. 
TABLE 6.25 DESIRABILITY VALUES - NUMBER OF PATENTS FILED

\begin{tabular}{|c|c|c|c|c|c|c|}
\hline $\begin{array}{c}\text { Number of } \\
\text { Patents } \\
\text { Filed }\end{array}$ & $\begin{array}{c}\text { More than 1 } \\
\text { per } \\
\text { Researcher }\end{array}$ & $\begin{array}{c}1 \text { Patent per } \\
1-10 \\
\text { Researchers }\end{array}$ & $\begin{array}{c}1 \text { Patent per } \\
11-50 \\
\text { Researchers }\end{array}$ & $\begin{array}{c}1 \text { Patent per } \\
51-100 \\
\text { Researchers }\end{array}$ & $\begin{array}{c}1 \text { Patent per } \\
101-1000 \\
\text { Researchers }\end{array}$ & $\begin{array}{c}1 \text { Patent per } \\
1000+ \\
\text { Researchers }\end{array}$ \\
\hline EXP1 & 70 & 65 & 50 & 40 & 30 & 10 \\
\hline EXP2 & 80 & 70 & 60 & 50 & 20 & 10 \\
\hline EXP3 & 85 & 75 & 60 & 50 & 30 & 10 \\
\hline EXP4 & 68 & 68 & 68 & 59 & 35 & 6 \\
\hline EXP5 & 90 & 100 & 50 & 20 & 10 & 0 \\
\hline Mean & 78.6 & 75.6 & 57.6 & 43.8 & 25 & 7.2 \\
\hline
\end{tabular}

\section{Number of Patents Granted}

The metric for this variable is the ratio of number of patents granted in the last three years to number of researchers in the company.

TABLE 6.26 DESIRABILITY VALUES - NUMBER OF PATENTS GRANTED

\begin{tabular}{|c|c|c|c|c|c|c|}
\hline $\begin{array}{c}\text { Number of } \\
\text { Patents } \\
\text { Granted }\end{array}$ & $\begin{array}{c}\text { More than 1 } \\
\text { per } \\
\text { Researcher }\end{array}$ & $\begin{array}{c}1 \text { Patent per } \\
1-10 \\
\text { Researchers }\end{array}$ & $\begin{array}{c}1 \text { Patent per } \\
11-50 \\
\text { Researchers }\end{array}$ & $\begin{array}{c}1 \text { Patent per } \\
51-100 \\
\text { Researchers }\end{array}$ & $\begin{array}{c}1 \text { Patent per } \\
101-1000 \\
\text { Researchers }\end{array}$ & $\begin{array}{c}1 \text { Patent per } \\
1000+ \\
\text { Researchers }\end{array}$ \\
\hline EXP2 & 80 & 70 & 60 & 50 & 30 & 10 \\
\hline EXP3 & 70 & 60 & 50 & 40 & 20 & 10 \\
\hline EXP4 & 70 & 75 & 65 & 55 & 25 & 15 \\
\hline EXP5 & 80 & 100 & 70 & 50 & 58 & 63 \\
\hline Mean & 77 & 74 & 61.2 & 52 & 30.6 & 0 \\
\hline
\end{tabular}

\section{Number of Patents Cited}

The metric for this variable is the ratio of number of patents cited in the last three years to number of researchers in the company.

TABLE 6.27 DESIRABILITY VALUES - NUMBER OF PATENTS CITED

\begin{tabular}{|c|c|c|c|c|c|c|}
\hline $\begin{array}{c}\text { Number of } \\
\begin{array}{c}\text { Patents } \\
\text { Cited }\end{array}\end{array}$ & $\begin{array}{c}\text { More than 1 } \\
\text { Per } \\
\text { Researcher }\end{array}$ & $\begin{array}{c}1 \text { Patent per } \\
1-10 \\
\text { Researchers }\end{array}$ & $\begin{array}{c}1 \text { Patent per } \\
11-50 \\
\text { Researchers }\end{array}$ & $\begin{array}{c}1 \text { Patent per } \\
51-100 \\
\text { Researchers }\end{array}$ & $\begin{array}{c}1 \text { Patent per } \\
101-1000 \\
\text { Researchers }\end{array}$ & $\begin{array}{c}1 \text { Patent per } \\
1000+ \\
\text { Researchers }\end{array}$ \\
\hline EXP1 & 70 & 60 & 50 & 40 & 20 & 10 \\
\hline EXP2 & 80 & 60 & 40 & 30 & 20 & 10 \\
\hline EXP3 & 85 & 70 & 60 & 55 & 25 & 10 \\
\hline EXP4 & 86 & 83 & 80 & 62 & 27 & 5 \\
\hline EXP5 & 70 & 80 & 100 & 70 & 40 & 20 \\
\hline Mean & 78.2 & 70.6 & 66 & 51.4 & 26.4 & 11 \\
\hline
\end{tabular}


Number of Papers Published

The metric for this variable is the ratio of number of papers published in scientific publications in the last three years to number of researchers in the company.

TABLE 6.28 DESIRABILITY VALUES - NUMBER OF PAPERS PUBLISHED

\begin{tabular}{|c|c|c|c|c|c|c|}
\hline $\begin{array}{c}\text { Number of } \\
\text { Papers } \\
\text { Published }\end{array}$ & $\begin{array}{c}\text { More than 1 } \\
\text { Per } \\
\text { Researcher }\end{array}$ & $\begin{array}{c}1 \text { Paper per } \\
1-10 \\
\text { Researchers }\end{array}$ & $\begin{array}{c}1 \text { Paper per } \\
11-50 \\
\text { Researchers }\end{array}$ & $\begin{array}{c}1 \text { Paper per } \\
51-100 \\
\text { Researchers }\end{array}$ & $\begin{array}{c}\text { 1 Paper per } \\
101-1000 \\
\text { Researchers }\end{array}$ & $\begin{array}{c}1 \text { Paper per } \\
1000+ \\
\text { Researchers }\end{array}$ \\
\hline EXP1 & 0 & 33 & 67 & 100 & 100 & 100 \\
\hline EXP2 & 10 & 50 & 70 & 50 & 30 & 10 \\
\hline EXP3 & 25 & 40 & 50 & 20 & 5 & 0 \\
\hline EXP4 & 0 & 25 & 80 & 40 & 10 & 0 \\
\hline Mean & 8.75 & 37 & 66.75 & 52.5 & 36.25 & 27.5 \\
\hline
\end{tabular}

\section{Number of Papers Cited}

The metric for this variable is the ratio of number of papers cited in the last three years to number of researchers in the company.

TABLE 6.29 DESIRABILITY VALUES - NUMBER OF PAPERS CITED

\begin{tabular}{|c|c|c|c|c|c|c|}
\hline $\begin{array}{c}\text { Number of } \\
\text { Papers Cited }\end{array}$ & $\begin{array}{c}\text { More than 1 } \\
\text { Per } \\
\text { Researcher }\end{array}$ & $\begin{array}{c}1 \text { Paper per } \\
1-10 \\
\text { Researchers }\end{array}$ & $\begin{array}{c}1 \text { Paper per } \\
11-50 \\
\text { Researchers }\end{array}$ & $\begin{array}{c}1 \text { Paper per } \\
51-100 \\
\text { Researchers }\end{array}$ & $\begin{array}{c}\text { 1 Paper per } \\
101-1000 \\
\text { Researchers }\end{array}$ & $\begin{array}{c}1 \text { Paper per } \\
1000+ \\
\text { Researchers }\end{array}$ \\
\hline EXP1 & 0 & 0 & 33 & 67 & 100 & 100 \\
\hline EXP2 & 20 & 40 & 50 & 60 & 30 & 10 \\
\hline EXP3 & 10 & 20 & 40 & 20 & 6 & 0 \\
\hline EXP4 & 0 & 10 & 40 & 20 & 10 & 0 \\
\hline Mean & 7.5 & 17.5 & 40.75 & 41.75 & 36.5 & 27.5 \\
\hline
\end{tabular}

\section{Number of Papers Presented}

The metric for this variable is the ratio of number of papers presented in the last three years to number of researchers in the company. 
TABLE 6.30 DESIRABILITY VALUES - NUMBER OF PAPERS PRESENTED

\begin{tabular}{|c|c|c|c|c|c|c|}
\hline $\begin{array}{c}\text { Number of } \\
\text { Papers } \\
\text { Presented }\end{array}$ & $\begin{array}{c}\text { More than 1 } \\
\text { per } \\
\text { Researcher }\end{array}$ & $\begin{array}{c}1 \text { Paper per } \\
1-10 \\
\text { Researchers }\end{array}$ & $\begin{array}{c}1 \text { Paper per } \\
11-50 \\
\text { Researchers }\end{array}$ & $\begin{array}{c}1 \text { Paper per } \\
51-100 \\
\text { Researchers }\end{array}$ & $\begin{array}{c}1 \text { Paper per } \\
101-1000 \\
\text { Researchers }\end{array}$ & $\begin{array}{c}1 \text { Paper per } \\
1000+ \\
\text { Researchers }\end{array}$ \\
\hline EXP1 & 0 & 33 & 67 & 100 & 100 & 100 \\
\hline EXP2 & 20 & 50 & 60 & 40 & 30 & 20 \\
\hline EXP3 & 30 & 55 & 40 & 35 & 15 & 0 \\
\hline EXP4 & 15 & 35 & 65 & 55 & 30 & 0 \\
\hline Mean & 16.25 & 43.25 & 58 & 57.5 & 43.75 & 30 \\
\hline
\end{tabular}

\section{$\underline{\text { Revenue from New Products }}$}

The metric for this variable is the revenue from new products, as a percentage of the total revenue received by the company in the last three years.

TABLE 6.31 DESIRABILITY VALUES - REVENUE FROM NEW PRODUCTS

\begin{tabular}{|c|c|c|c|c|c|c|}
\hline Revenue from New Products & $0 \%$ & $20 \%$ & $40 \%$ & $60 \%$ & $80 \%$ & $100 \%$ \\
\hline EXP1 & 0 & 40 & 70 & 90 & 50 & 10 \\
\hline EXP2 & 0 & 40 & 65 & 85 & 60 & 0 \\
\hline EXP3 & 0 & 9 & 48 & 85 & 84 & 10 \\
\hline EXP4 & 0 & 30 & 75 & 90 & 65 & 10 \\
\hline EXP5 & 0 & 20 & 50 & 90 & 90 & 70 \\
\hline EXP6 & 0 & 100 & 80 & 40 & 35 & 30 \\
\hline Mean & 0 & 39.83 & 64.67 & 80.00 & 64.00 & 21.67 \\
\hline
\end{tabular}

\section{Market Share from New Products}

The metric for this variable is the highest market share of the new product developed by the company in the last three years. (For example, suppose a company has developed 4 new products in the last 3 years, and the highest share they have achieved in their market since introduction is $15 \%, 10 \%, 80 \%, 30 \%$ respectively. The metric used for this variable is $80 \%$.) 
TABLE 6.32 DESIRABILITY VALUES -MARKET SHARE FROM NEW PRODUCTS

\begin{tabular}{|c|c|c|c|c|c|c|}
\hline Market Share from New Products & $0 \%$ & $20 \%$ & $40 \%$ & $60 \%$ & $80 \%$ & $1000 \%$ \\
\hline EXP1 & 0 & 25 & 40 & 65 & 85 & 40 \\
\hline EXP2 & 0 & 0 & 20 & 60 & 100 & 20 \\
\hline EXP3 & 0 & 10 & 30 & 65 & 95 & 85 \\
\hline EXP4 & 0 & 20 & 50 & 60 & 90 & 40 \\
\hline EXP5 & 0 & 25 & 50 & 80 & 100 & 100 \\
\hline EXP6 & 0 & 30 & 40 & 60 & 80 & 35 \\
\hline Mean & 0 & 18.33 & 38.33 & 65.00 & 91.67 & 53.33 \\
\hline
\end{tabular}

\subsubsection{Analysis and Validation of Expert Panel 3 Results}

The arithmetic means of the experts were used. Validation by using F-test was performed to check if there is a statistically significant difference among experts. If there is a statistically significant difference, the outliner is excluded and the F-test is performed again to recheck the results. Hypotheses were developed to test the disagreement.

$\mathrm{H}_{0}: \mathrm{r}_{\mathrm{ic}}=0$ there is disagreement

$\mathrm{H}_{\mathrm{a}}: \mathrm{r}_{\mathrm{ic}}>0$ there is statistically significant evidence that there is some level of agreement

Once the null hypothesis is rejected, the arithmetic means of that specific condition is utilized in the framework.

\section{Number of New Products New to the World}

The responses from the experts were analyzed to find the intraclass correlation coefficient and computed F-value. The value of the intraclass correlation is 0.539 , and the computed F-value is 10.116 . The F-critical at 0.01 is 4.10277 . Because the computed Fvalue is higher than F-critical, the null hypothesis can be rejected. It means that there is no statistically significant difference among experts in the desirability value of number of 
new products new to the world. Thus, the arithmetic means of the experts from Table 6.21 are used to create the desirability curve.

TABLE 6.33 INTRACLASS CORRELATION COEFFICIENT OF DESIRABILITY VALUE OF NUMBER OF NEW PRODUCTS THAT ARE NEW TO THE WORLD

\begin{tabular}{|l|r|r|r|r|r|r|r|}
\hline \multicolumn{1}{|c|}{ Intraclass Correlation Coefficient } \\
\cline { 3 - 8 } & \multirow{2}{*}{$\begin{array}{c}\text { Intraclass } \\
\text { Correlation }\end{array}$} & \multicolumn{2}{|c|}{$99 \%$ Confidence Interval } & \multicolumn{3}{|c|}{ F Test with True Value 0 } \\
\cline { 3 - 9 } & Lower Bound & Upper Bound & Value & df1 & df2 & Sig \\
\hline Single Measures & $.539^{\mathrm{a}}$ & .110 & .944 & 10.116 & 5 & 20 & .000 \\
Average Measures & .854 & .381 & .988 & 10.116 & 5 & 20 & .000 \\
\hline
\end{tabular}

Two-way random effects model where both people effects and measures effects are random.

a. The estimator is the same, whether the interaction effect is present or not.

b. Type A intraclass correlation coefficients using an absolute agreement definition.

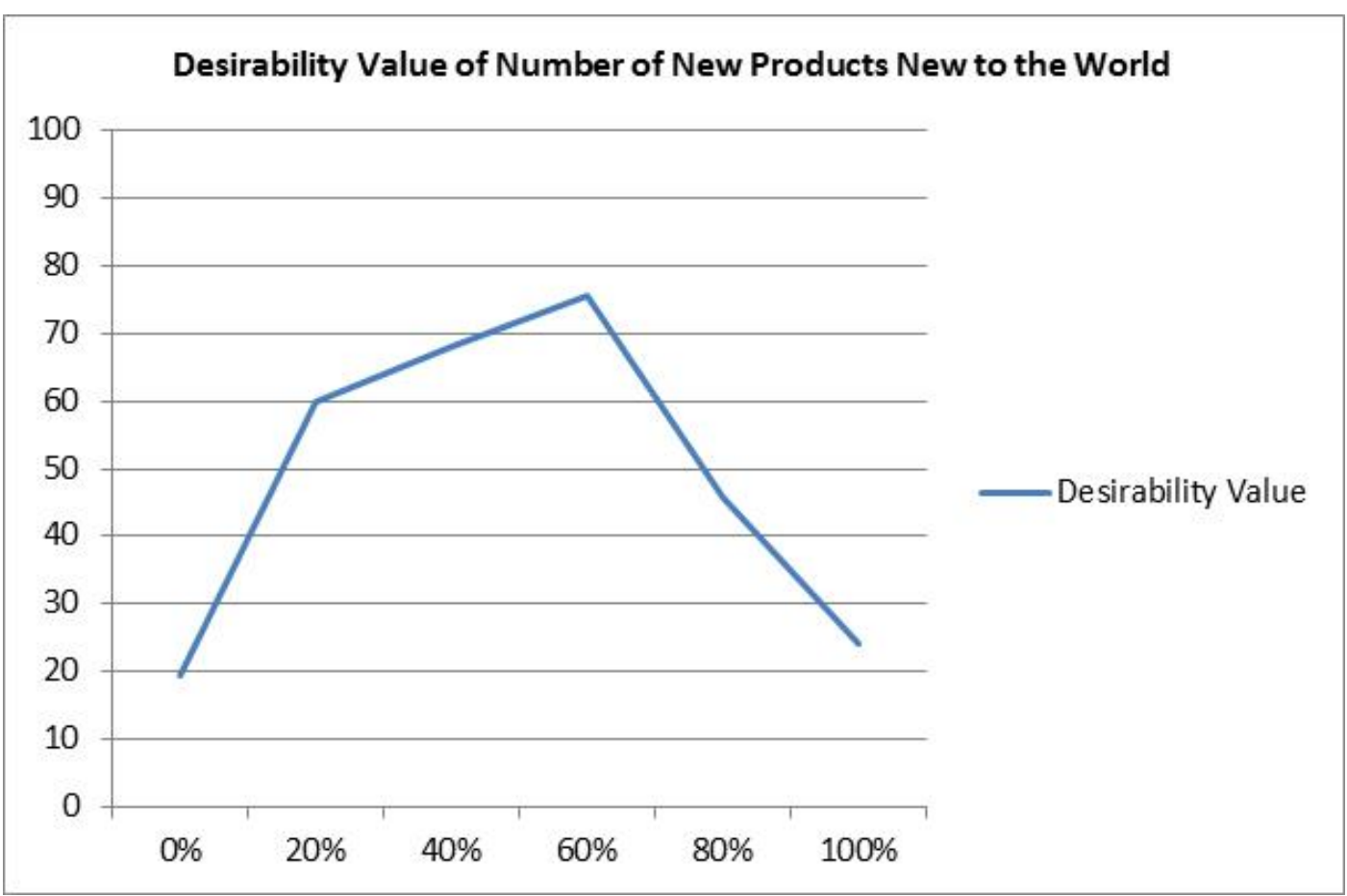

Figure 6.7 The Desirability Value of Number of New Products New to the World 


\section{Number of New Products New to the Company}

The intraclass correlation is 0.728 (see Table 6.34). It is fairly high as the value is close to 1 . The computed F-value is 13.148 . The F-critical at 0.01 is 4.1027 . Because the F-critical is lower than the F computed, the null hypothesis can be rejected. It means that there is no statistically significant difference among experts regarding the desirability value of number of new products new to the company. Thus, the arithmetic means from Table 6.22 are used to create the desirability curve.

TABLE 6.34 INTRACLASS CORRELATION COEFFICIENT OF DESIRABILITY VALUE OF NUMBER OF NEW PRODUCTS THAT ARE NEW TO THE COMPANY

\begin{tabular}{|l|r|r|r|r|r|r|r|}
\hline \multicolumn{1}{|c|}{ Intraclass Correlation Coefficient } \\
\cline { 3 - 9 } & \multirow{2}{*}{$\begin{array}{c}\text { Intraclass } \\
\text { Correlation }\end{array}$} & \multicolumn{2}{|c|}{$99 \%$ Confidence Interval } & \multicolumn{4}{|c|}{ F Test with True Value 0 } \\
\cline { 3 - 9 } & & Lower Bound & Upper Bound & Value & df1 & df2 & Sig \\
\hline Single Measures & $.387^{\mathrm{a}}$ & -.031 & .914 & 3.927 & 5 & 20 & .012 \\
Average Measures & .759 & -.178 & .982 & 3.927 & 5 & 20 & .012 \\
\hline
\end{tabular}

Two-way random effects model where both people effects and measures effects are random.

a. The estimator is the same, whether the interaction effect is present or not.

b. Type A intraclass correlation coefficients using an absolute agreement definition.

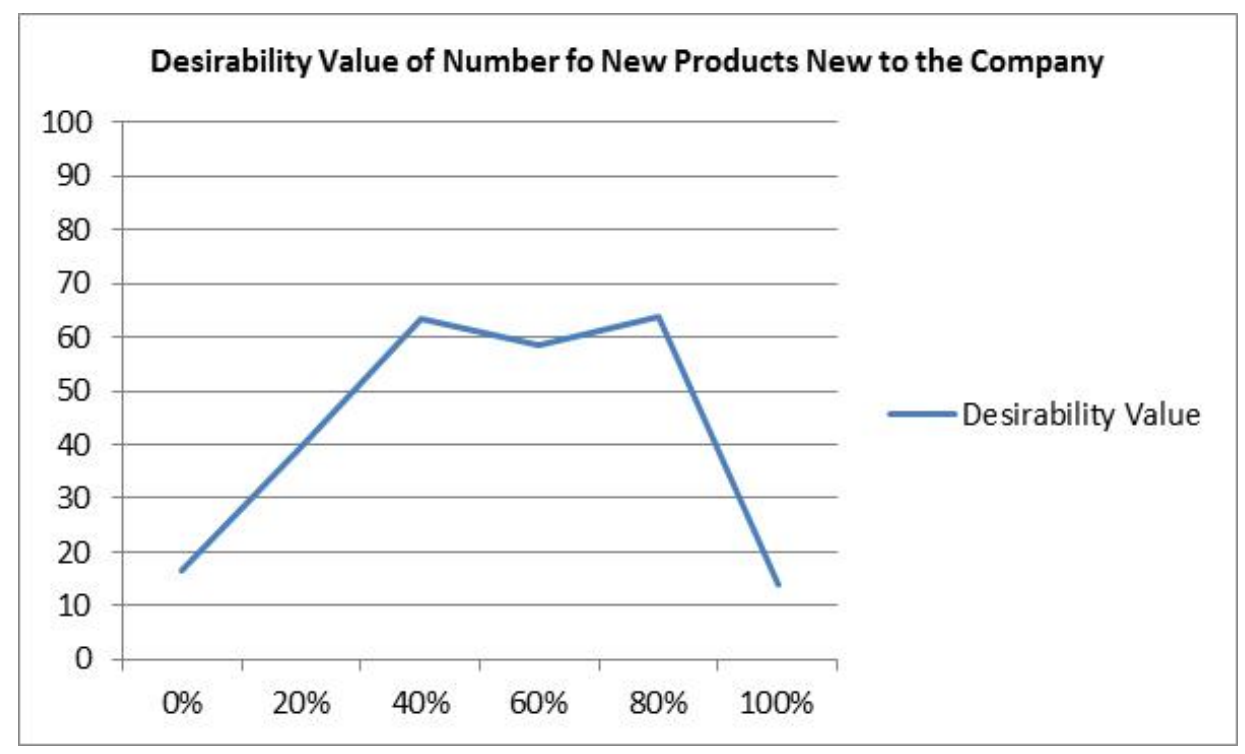

Figure 6.8 The Desirability Value of Number of New Products New to the Company 


\section{$\underline{\text { Number of Innovation Awards }}$}

The intraclass correlation of the experts for this desirability value is very low with the value of 0.123 (see Table 6.35). The computed F-value is 1.536 , while the F-critical at 0.01 is 4.5556 . Because the computed F-value is lower than F-critical, the null hypothesis cannot be rejected. It means that there is a statistically significant difference among experts. Thus, the arithmetic means from Table 6.23 cannot be used.

\section{TABLE 6.35 INTRACLASS CORRELATION COEFFICIENT OF DESIRABILITY VALUE OF NUMBER OF INNOVATION AWARDS}

\begin{tabular}{|l|r|r|r|r|r|r|r|}
\hline & \multicolumn{1}{|c|}{ Intraclass Correlation Coefficient } \\
\cline { 4 - 9 } & \multirow{2}{*}{$\begin{array}{c}\text { Intraclass } \\
\text { Correlation }^{\mathrm{b}}\end{array}$} & \multicolumn{2}{|c|}{$99 \%$ Confidence Interval } & \multicolumn{4}{|c|}{ F Test with True Value 0 } \\
\cline { 3 - 9 } & $.123^{\mathrm{a}}$ & -.227 & .834 & 1.536 & 5 & 15 & .238 \\
\hline Single Measures & .360 & -2.836 & .952 & 1.536 & 5 & 15 & .238 \\
\hline
\end{tabular}

Two-way random effects model where both people effects and measures effects are random.

a. The estimator is the same, whether the interaction effect is present or not.

b. Type A intraclass correlation coefficients using an absolute agreement definition.

Further analysis was performed to find the desirability curve. EXP 1, who has a major dissimilarity compared to other experts, was excluded. After EXP 1 was excluded, the intraclass correlation coefficient increased to 0.596 (see table 6.36). The computed Fvalue is 5.721. F-critical at 0.01 is 5.6363 . Because the computed $\mathrm{F}$ value is higher than F-critical, the null hypothesis can be rejected. Thus, the new arithmetic means that excludes EXP 1 is used to create the desirability function. 
TABLE 6.36 INTRACLASS CORRELATION COEFFICIENT OF DESIRABILITY VALUE OF NUMBER OF INNOVATION AWARDS (EXCLUDING EXP1)

Intraclass Correlation Coefficient

\begin{tabular}{|l|r|r|r|r|r|r|r|}
\hline & \multirow{2}{*}{$\begin{array}{c}\text { Intraclass } \\
\text { Correlation }\end{array}$} & \multicolumn{2}{|c|}{$99 \%$ Confidence Interval } & \multicolumn{4}{|c|}{ F Test with True Value 0 } \\
\cline { 3 - 9 } & Lower Bound & Upper Bound & Value & df1 & \multicolumn{1}{|c|}{ df2 } & Sig \\
\hline Single Measures & $.596^{\mathrm{a}}$ & -.019 & .959 & 5.721 & 5 & 10 & .010 \\
Average Measures & .816 & -.058 & .986 & 5.721 & 5 & 10 & .010 \\
\hline
\end{tabular}

Two-way random effects model where both people effects and measures effects are random.

a. The estimator is the same, whether the interaction effect is present or not.

b. Type A intraclass correlation coefficients using an absolute agreement definition.

TABLE 6.37 DESIRABILITY VALUE - NUMBER OF INNOVATION AWARDS (EXCLUDING EXP1)

\begin{tabular}{|c|c|c|c|c|c|c|}
\hline $\begin{array}{c}\text { Number of } \\
\text { Innovation } \\
\text { Awards }\end{array}$ & $\begin{array}{c}\text { More than 1 } \\
\text { per } \\
\text { Researcher }\end{array}$ & $\begin{array}{c}1 \text { Award per } \\
1-10 \\
\text { Researchers }\end{array}$ & $\begin{array}{c}1 \text { Award per } \\
11-50 \\
\text { Researchers }\end{array}$ & $\begin{array}{c}1 \text { Award per } \\
51-100 \\
\text { Researchers }\end{array}$ & $\begin{array}{c}1 \text { Award per } \\
101-1000 \\
\text { Researchers }\end{array}$ & $\begin{array}{c}1 \text { Award per } \\
1000+ \\
\text { Researchers }\end{array}$ \\
\hline EXP2 & 10 & 70 & 50 & 30 & 20 & 0 \\
\hline EXP3 & 20 & 30 & 50 & 70 & 40 & 10 \\
\hline EXP4 & 30 & 60 & 100 & 60 & 30 & 0 \\
\hline Mean & 20 & 53.33 & 66.67 & 53.33 & 30.00 & 3.33 \\
\hline
\end{tabular}

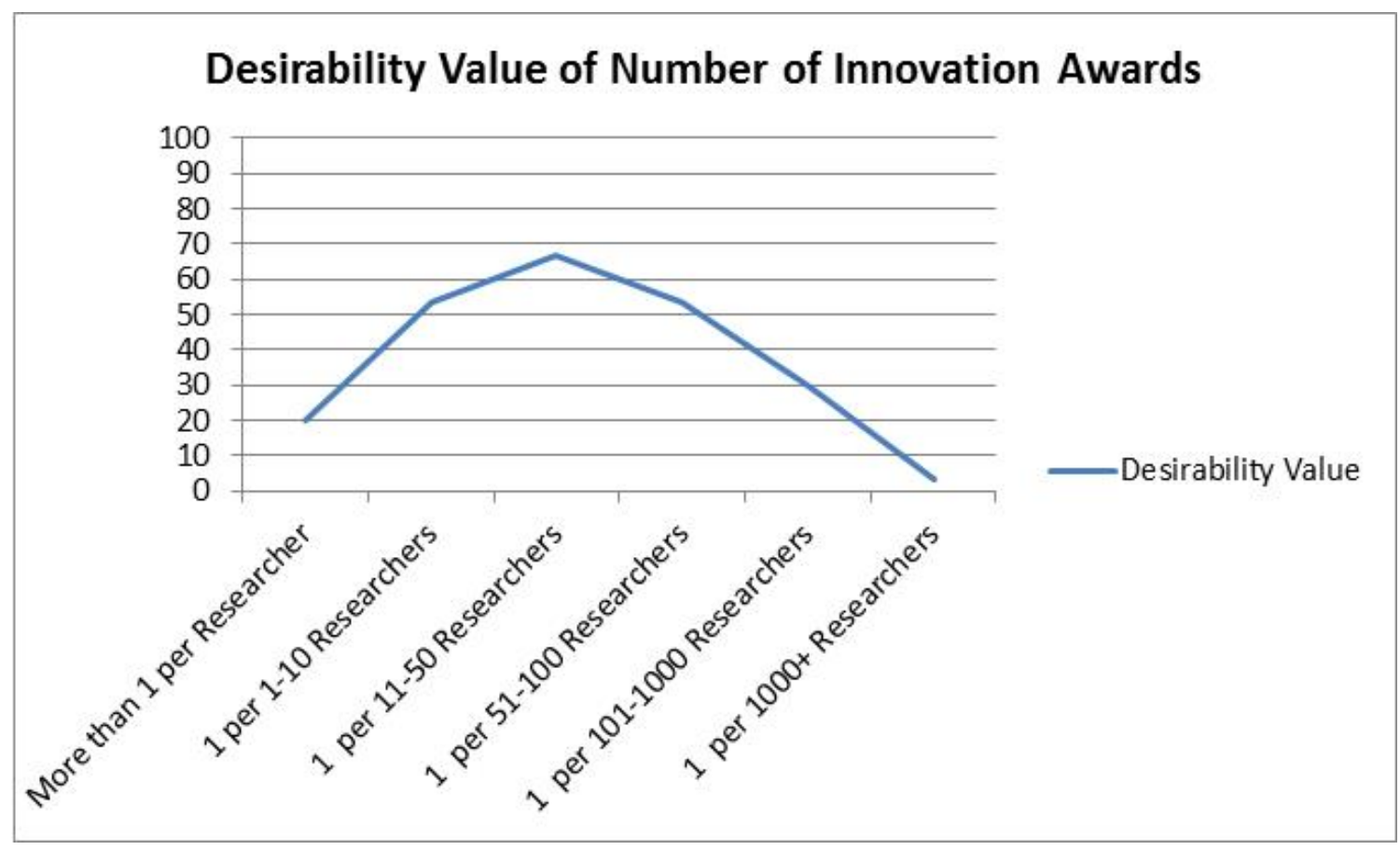

Figure 6.9 The Desirability Value of Number of Innovation Awards 


\section{Number of Innovation Honors}

Similar with number of innovation awards, number of innovation honors also received a low intraclass correlation coefficient with the value of 0.203. Computed Fvalue is 2.002 , while F-critical at 0.01 is 4.5556 . The null hypothesis cannot be rejected because F-critical is higher than the computed F-value. Thus, the arithmetic means from Table 6.24 cannot be used because there is a statistically significant difference among experts.

\section{TABLE 6.38 INTRACLASS CORRELATION COEFFICIENT OF DESIRABILITY VALUE OF NUMBER OF INNOVATION HONORS}

\begin{tabular}{|l|r|r|r|r|r|r|r|}
\hline \multicolumn{1}{|c|}{ Intraclass Correlation Coefficient } \\
\cline { 4 - 9 } & \multirow{2}{*}{$\begin{array}{c}\text { Intraclass } \\
\text { Correlation }\end{array}$} & \multicolumn{2}{|c|}{$99 \%$ Confidence Interval } & \multicolumn{3}{|c|}{ F Test with True Value 0 } \\
\cline { 3 - 9 } & & Lower Bound & Upper Bound & Value & df1 & df2 & Sig \\
\hline Single Measures & $.203^{\mathrm{a}}$ & -.182 & .864 & 2.002 & 5 & 15 & .137 \\
Average Measures & .505 & -1.602 & .962 & 2.002 & 5 & 15 & .137 \\
\hline
\end{tabular}

Two-way random effects model where both people effects and measures effects are random.

a. The estimator is the same, whether the interaction effect is present or not.

b. Type A intraclass correlation coefficients using an absolute agreement definition.

Further analysis was performed, and EXP 1 is the outlier with a value that contradicted with other experts. After EXP1 was excluded, the intraclass correlation coefficient is higher with the value of 0.683 . The computed F-value is 8.320 , while the Fcritical at the 0.01 level is 5.6363. Because the computed F-value is higher than F-critical, the null hypothesis can be rejected. The new desirability values that excluded EXP1 are used to create the desirability function. 
TABLE 6.39 INTRACLASS CORRELATION COEFFICIENT OF DESIRABILITY VALUE OF NUMBER OF INNOVATION HONORS (EXCLUDING EXP1)

Intraclass Correlation Coefficient

\begin{tabular}{|l|r|r|r|r|r|r|r|}
\hline & \multirow{2}{*}{$\begin{array}{c}\text { Intraclass } \\
\text { Correlation }\end{array}$} & \multicolumn{2}{|c|}{$99 \%$ Confidence Interval } & \multicolumn{4}{|c|}{ F Test with True Value 0 } \\
\cline { 3 - 8 } & Lower Bound & Upper Bound & Value & df1 & \multicolumn{1}{c|}{ df2 } & Sig \\
\hline Single Measures & $.683^{\mathrm{a}}$ & .093 & .970 & 8.320 & 5 & 10 & .002 \\
Average Measures & .866 & .234 & .990 & 8.320 & 5 & 10 & .002 \\
\hline
\end{tabular}

Two-way random effects model where both people effects and measures effects are random.

a. The estimator is the same, whether the interaction effect is present or not.

b. Type A intraclass correlation coefficients using an absolute agreement definition.

TABLE 6.40 DESIRABILITY VALUE - NUMBER OF INNOVATION HONORS (EXCLUDING EXP1)

\begin{tabular}{|c|c|c|c|c|c|c|}
\hline $\begin{array}{c}\text { Number of } \\
\text { Innovation } \\
\text { Honors }\end{array}$ & $\begin{array}{c}\text { More than 1 } \\
\text { Per } \\
\text { Researcher }\end{array}$ & $\begin{array}{c}1 \text { Award per } \\
1-10 \\
\text { Researchers }\end{array}$ & $\begin{array}{c}1 \text { Award per } \\
11-50 \\
\text { Researchers }\end{array}$ & $\begin{array}{c}1 \text { Award per } \\
51-100 \\
\text { Researchers }\end{array}$ & $\begin{array}{c}1 \text { Award per } \\
101-1000 \\
\text { Researchers }\end{array}$ & $\begin{array}{c}1 \text { Award per } \\
1000+ \\
\text { Researchers }\end{array}$ \\
\hline EXP2 & 20 & 50 & 43 & 48 & 31 & 5 \\
\hline EXP3 & 10 & 40 & 50 & 60 & 45 & 30 \\
\hline EXP4 & 30 & 50 & 70 & 60 & 60 & 0 \\
\hline Mean & 20 & 46.67 & 54.33 & 56.00 & 45.33 & 11.67 \\
\hline
\end{tabular}

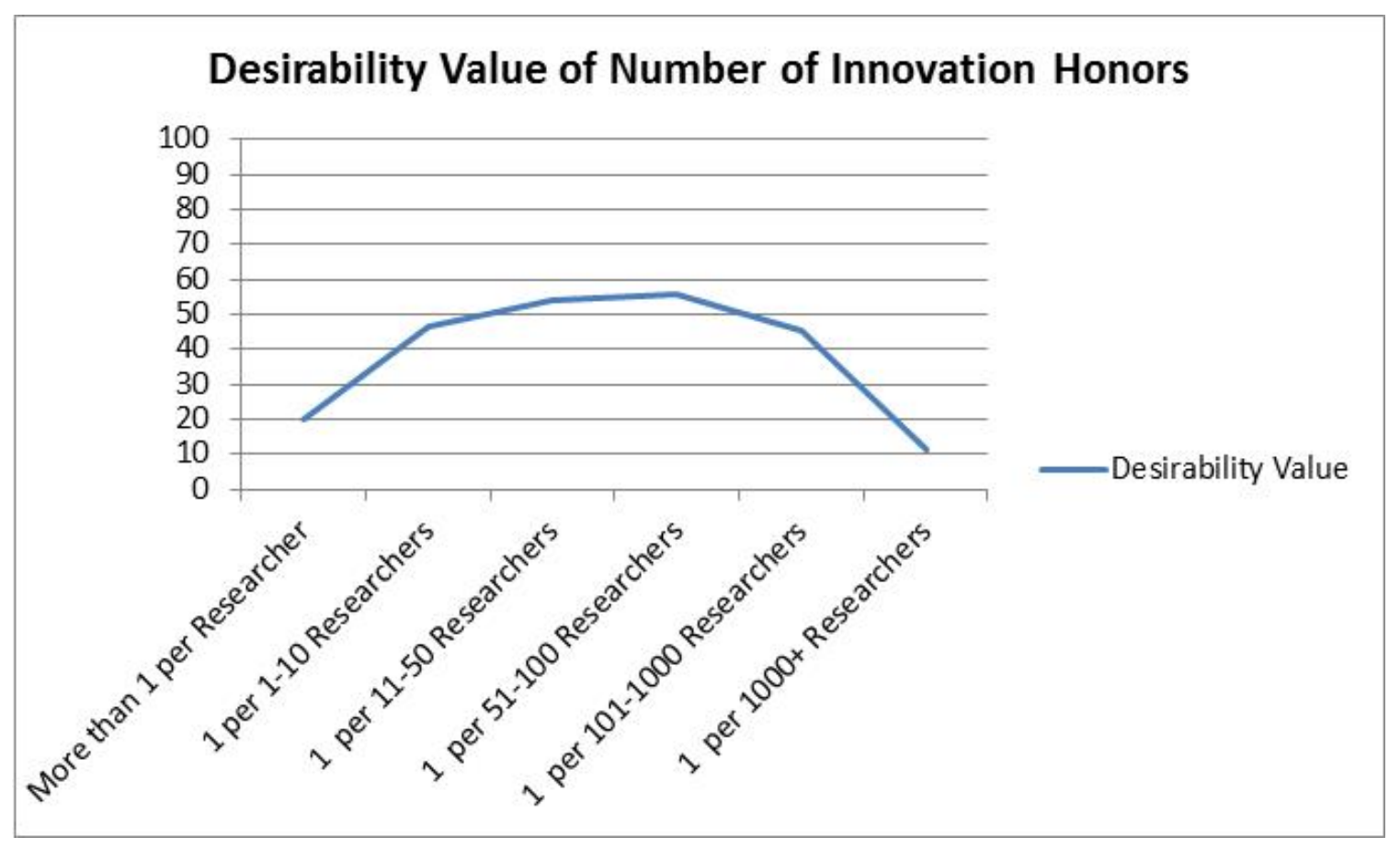

Figure 6.10 The Desirability Value of Number of Innovation Honors 


\section{$\underline{\text { Number of Patents Filed }}$}

The intraclass correlation coefficient for number of patents filed is high with the value of 0.871 . The computed F-value is 32.137 . The F-critical at 0.01 is 4.1027 . Because the F-critical is lower than the computed F-value, the null hypothesis can be rejected. It means that there is no statistically significant difference among experts. Thus, the arithmetic means from Table 6.25 can be used to create the desirability curve.

\section{TABLE 6.41 INTRACLASS CORRELATION COEFFICIENT OF DESIRABILITY VALUE OF NUMBER OF PATENTS FILED}

\begin{tabular}{|l|r|r|r|r|r|r|r|}
\hline \multicolumn{1}{|c|}{ Intraclass Correlation Coefficient } \\
\cline { 4 - 9 } & \multirow{2}{*}{$\begin{array}{c}\text { Intraclass } \\
\text { Correlation }\end{array}$} & \multicolumn{2}{|c|}{$99 \%$ Confidence Interval } & \multicolumn{3}{|c|}{ F Test with True Value 0 } \\
\cline { 3 - 9 } & Lower Bound & Upper Bound & Value & df1 & df2 & Sig \\
\hline Single Measures & $.871^{\mathrm{a}}$ & .569 & .989 & 32.127 & 5 & 20 & .000 \\
Average Measures & .971 & .868 & .998 & 32.127 & 5 & 20 & .000 \\
\hline
\end{tabular}

Two-way random effects model where both people effects and measures effects are random.

a. The estimator is the same, whether the interaction effect is present or not.

b. Type A intraclass correlation coefficients using an absolute agreement definition.

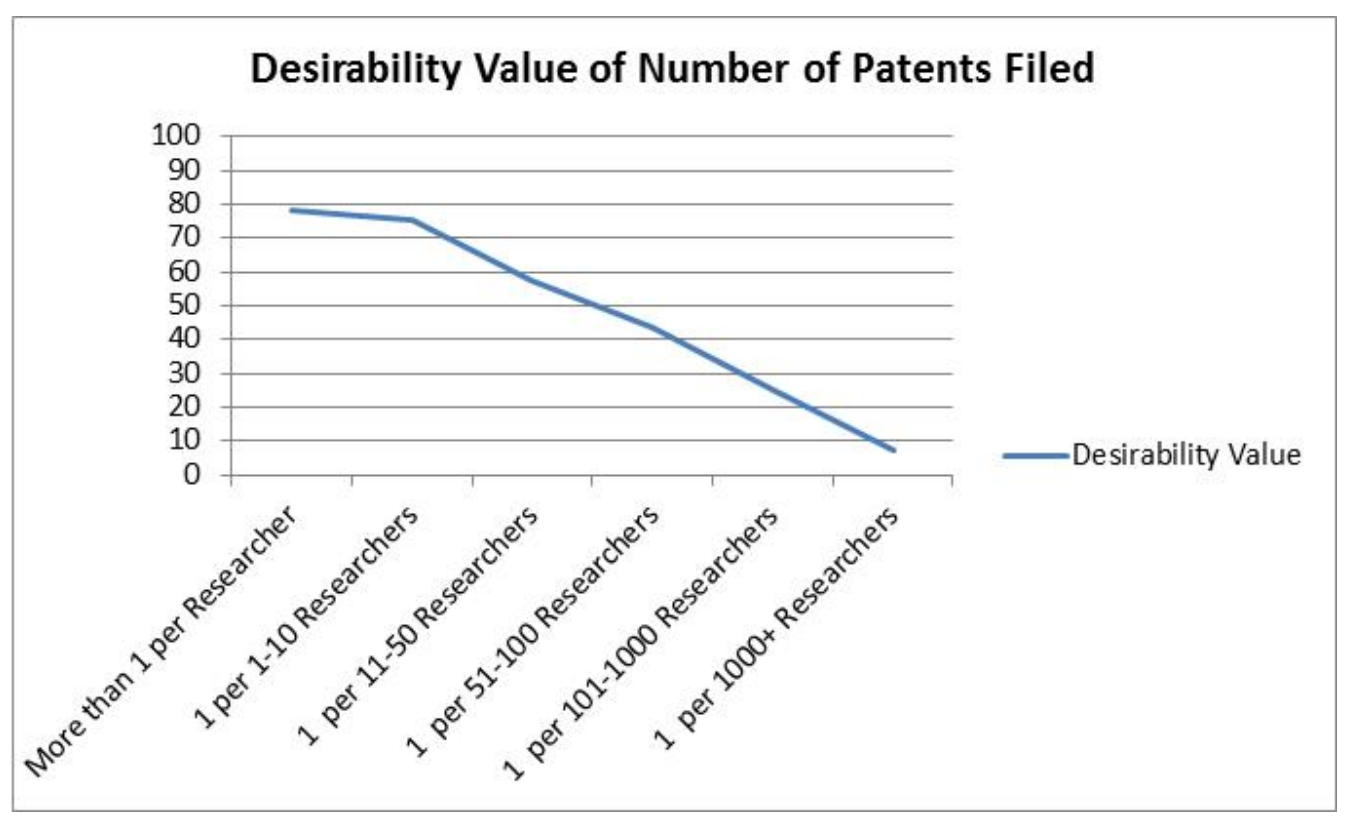

Figure 6.11 The Desirability Value of Number of Patents Filed 


\section{Number of Patents Granted}

The intraclass correlation coefficient for number of patents granted is 0.7 . It is considered high as it is closed to 1 . The computed F-value is 14.671, while the F-critical at 0.01 is 4.1027 . The null hypothesis can be rejected since the computed F-value is higher than F-critical. The arithmetic means from Table 6.26 can be used to create the desirability curve.

\section{TABLE 6.42 INTRACLASS CORRELATION COEFFICIENT OF DESIRABILITY VALUE OF NUMBER OF PATENTS GRANTED}

\begin{tabular}{|l|r|r|r|r|r|r|r|}
\hline & \multicolumn{1}{|c|}{ Intraclass Correlation Coefficient } \\
\cline { 3 - 9 } & \multirow{2}{*}{$\begin{array}{c}\text { Intraclass } \\
\text { Correlation }^{\mathrm{b}}\end{array}$} & \multicolumn{2}{|c|}{$99 \%$ Confidence Interval } & \multicolumn{4}{|c|}{ F Test with True Value 0 } \\
\cline { 3 - 9 } & & Lower Bound & Upper Bound & Value & df1 & df2 & Sig \\
\hline Single Measures & $.700^{\mathrm{a}}$ & .273 & .970 & 14.671 & 5 & 20 & .000 \\
Average Measures & .921 & .652 & .994 & 14.671 & 5 & 20 & .000 \\
\hline
\end{tabular}

Two-way random effects model where both people effects and measures effects are random.

a. The estimator is the same, whether the interaction effect is present or not.

b. Type A intraclass correlation coefficients using an absolute agreement definition.

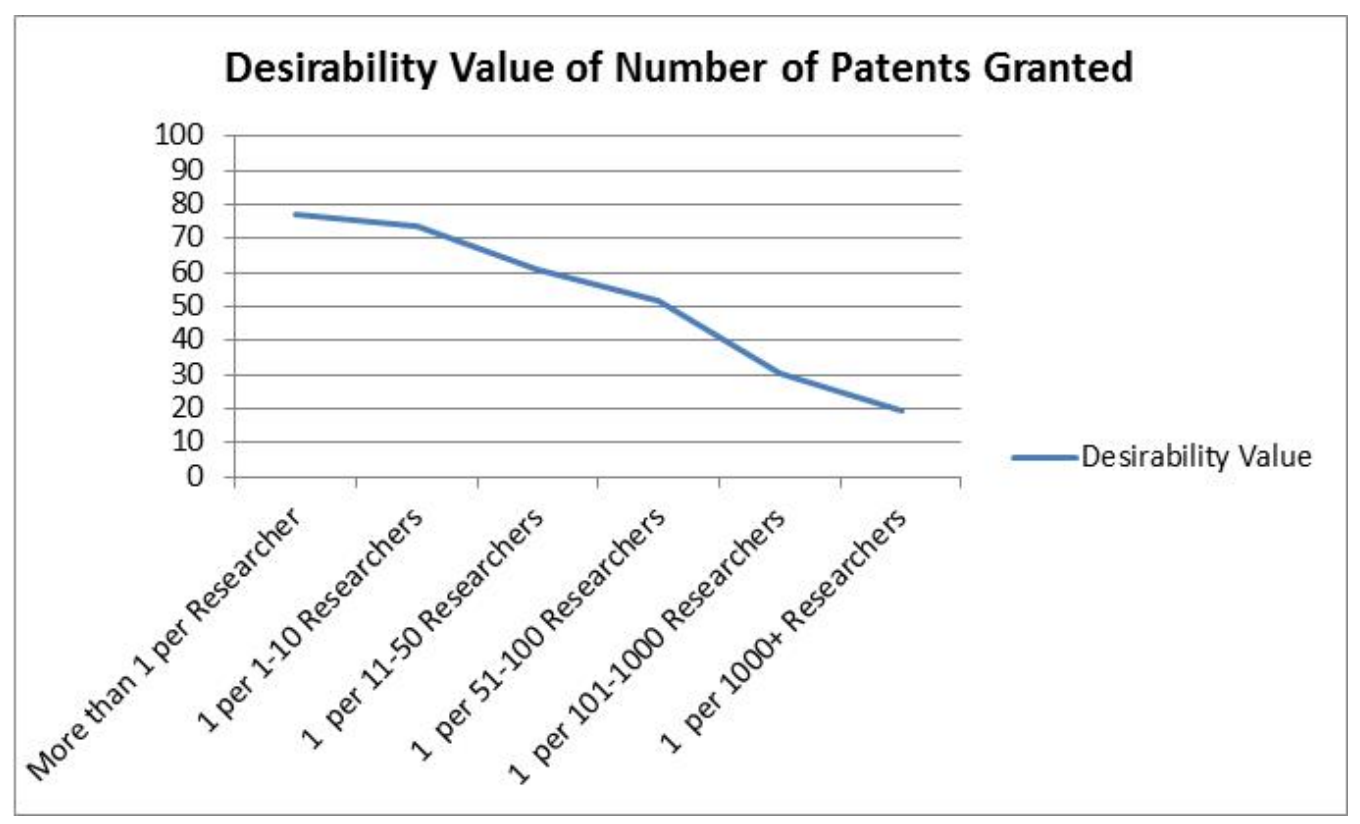

Figure 6.12 The Desirability Value of Number of Patents Granted 


\section{Number of Patents Cited}

The responses from the experts in respect to the number of patents cited were analyzed. The intraclass correlation coefficient is close to 1 with the value of 0.787 . The F-critical at 0.01 is 4.1027. The computed F-value is 33.914. Since the computed F-value is higher than F-critical, the null hypothesis can be rejected. There is no statistically significant difference among experts, thus the arithmetic means from Table 6.27 can be used to create the desirability curve.

\section{TABLE 6.43 INTRACLASS CORRELATION COEFFICIENT OF DESIRABILITY VALUE OF NUMBER OF PATENTS CITED}

\begin{tabular}{|l|r|r|r|r|r|r|r|}
\hline \multicolumn{1}{|c|}{ Intraclass Correlation Coefficient } \\
\cline { 3 - 9 } & \multirow{2}{*}{$\begin{array}{c}\text { Intraclass } \\
\text { Correlation }\end{array}$} & \multicolumn{2}{|c|}{$99 \%$ Confidence Interval } & \multicolumn{4}{|c|}{ F Test with True Value 0 } \\
\cline { 3 - 9 } & Lower Bound & Upper Bound & Value & df1 & df2 & Sig \\
\hline Single Measures & $.787^{\mathrm{a}}$ & .350 & .981 & 33.914 & 5 & 20 & .000 \\
Average Measures & .949 & .729 & .996 & 33.914 & 5 & 20 & .000 \\
\hline
\end{tabular}

Two-way random effects model where both people effects and measures effects are random.

a. The estimator is the same, whether the interaction effect is present or not.

b. Type A intraclass correlation coefficients using an absolute agreement definition.

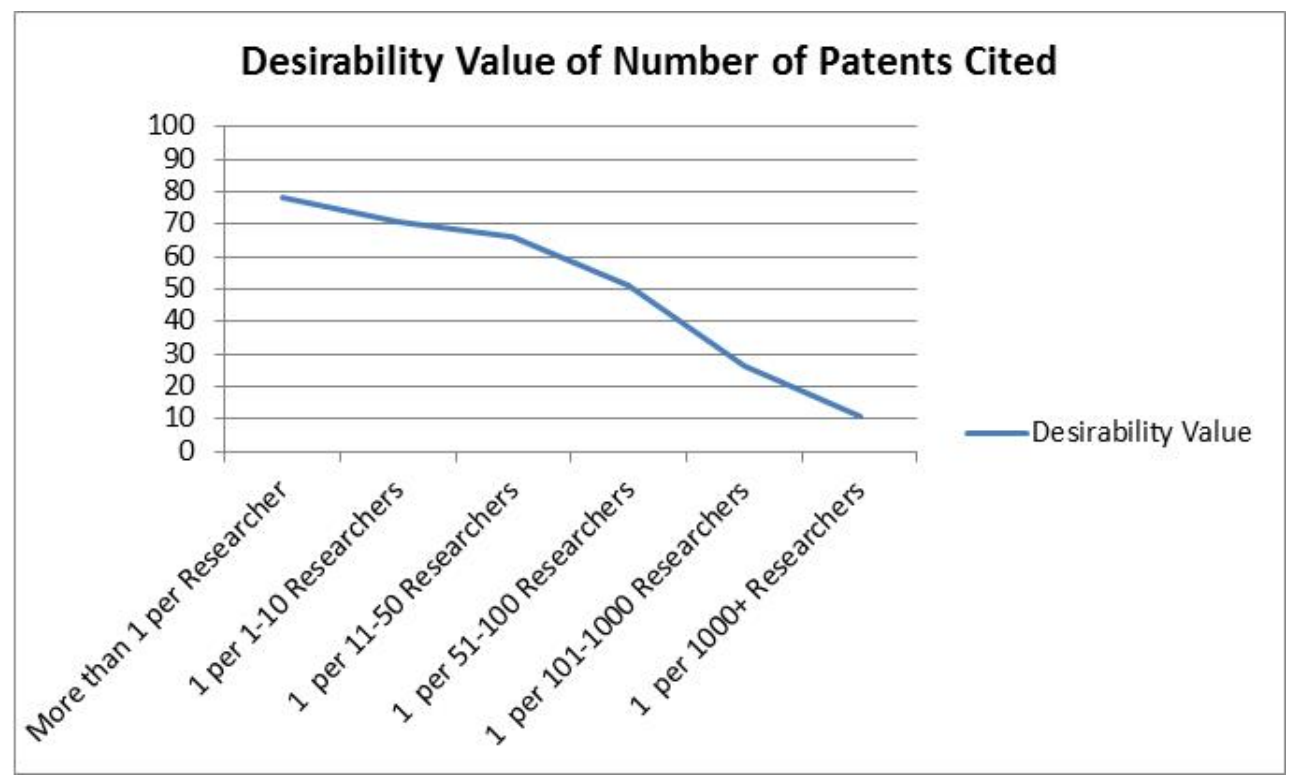

Figure 6.13 The Desirability Value of Number of Patents Cited 


\section{Number of Papers Published}

The intraclass correlation from the experts regarding the number of papers published is low with the value of 0.189 . It is close to 0 . The computed F-value is 2.31 , while the F-critical at 0.01 is 4.5556 . The null hypothesis cannot be rejected because the computed F-value is lower than F-critical. Thus, the arithmetic means from Table 6.28 cannot be used.

\section{TABLE 6.44 INTRACLASS CORRELATION COEFFICIENT OF DESIRABILITY VALUE OF NUMBER OF PAPERS PUBLISHED}

\begin{tabular}{|l|r|r|r|r|r|r|r|}
\hline & \multirow{2}{|c|}{ Intraclass Correlation Coefficient } \\
\cline { 4 - 9 } & \multirow{2}{*}{$\begin{array}{c}\text { Intraclass } \\
\text { Correlation }\end{array}$} & \multicolumn{2}{c|}{$99 \%$ Confidence Interval } & \multicolumn{4}{|c|}{ F Test with True Value 0 } \\
\cline { 3 - 9 } & & Lower Bound & Upper Bound & Value & df1 & \multicolumn{1}{c|}{ df2 } & Sig \\
\hline Single Measures & $.189^{\mathrm{a}}$ & -.106 & .838 & 2.310 & 5 & 15 & .096 \\
Average Measures & .483 & -.625 & .954 & 2.310 & 5 & 15 & .096 \\
\hline
\end{tabular}

Two-way random effects model where both people effects and measures effects are random.

a. The estimator is the same, whether the interaction effect is present or not.

b. Type A intraclass correlation coefficients using an absolute agreement definition.

After the analysis, it was found that EXP1 is the outlier. After the result from EXP1 is excluded, the intraclass correlation increases drastically to 0.751 . The computed F-value is 11.817 . The F-critical at 0.01 is 5.6363. Since the computed F-value is higher than F-critical, the null hypothesis can be rejected. It means that after EXP1 was excluded, there is no statistically significant difference among experts. The new arithmetic mean that excludes EXP 1 is used to create the desirability curve. 
TABLE 6.45 INTRACLASS CORRELATION COEFFICIENT OF DESIRABILITY VALUE OF NUMBER OF PAPERS PUBLISHED (EXCLUDING EXP1)

Intraclass Correlation Coefficient

\begin{tabular}{|l|r|r|r|r|r|r|r|}
\hline & \multirow{2}{*}{$\begin{array}{c}\text { Intraclass } \\
\text { Correlation }\end{array}$} & \multicolumn{3}{|c|}{$99 \%$ Confidence Interval } & \multicolumn{4}{|c|}{ F Test with True Value 0 } \\
\cline { 3 - 9 } & & Lower Bound & Upper Bound & Value & df1 & \multicolumn{1}{c|}{ df2 } & Sig \\
\hline Single Measures & $.751^{\mathrm{a}}$ & .190 & .978 & 11.817 & 5 & 10 & .001 \\
Average Measures & .900 & .413 & .992 & 11.817 & 5 & 10 & .001 \\
\hline
\end{tabular}

Two-way random effects model where both people effects and measures effects are random.

a. The estimator is the same, whether the interaction effect is present or not.

b. Type A intraclass correlation coefficients using an absolute agreement definition.

TABLE 6. 46 DESIRABILITY VALUE - NUMBER OF PAPERS PUBLISHED (EXCLUDING EXP1)

\begin{tabular}{|c|c|c|c|c|c|c|}
\hline $\begin{array}{c}\text { Number } \\
\text { of Papers } \\
\text { Published }\end{array}$ & $\begin{array}{c}\text { More than 1 } \\
\text { Per } \\
\text { Researcher }\end{array}$ & $\begin{array}{c}1 \text { Paper per } \\
1-10 \\
\text { Researchers }\end{array}$ & $\begin{array}{c}1 \text { Paper per } \\
11-50 \\
\text { Researchers }\end{array}$ & $\begin{array}{c}1 \text { Paper per } \\
51-100 \\
\text { Researchers }\end{array}$ & $\begin{array}{c}1 \text { Paper per } \\
101-1000 \\
\text { Researchers }\end{array}$ & $\begin{array}{c}1 \text { Paper per } \\
1000+ \\
\text { Researchers }\end{array}$ \\
\hline EXP2 & 10 & 50 & 70 & 50 & 30 & 10 \\
\hline EXP3 & 25 & 40 & 50 & 20 & 5 & 0 \\
\hline EXP4 & 0 & 25 & 80 & 40 & 10 & 0 \\
\hline Mean & 11.67 & 38.33 & 66.67 & 36.67 & 15.00 & 3.33 \\
\hline
\end{tabular}

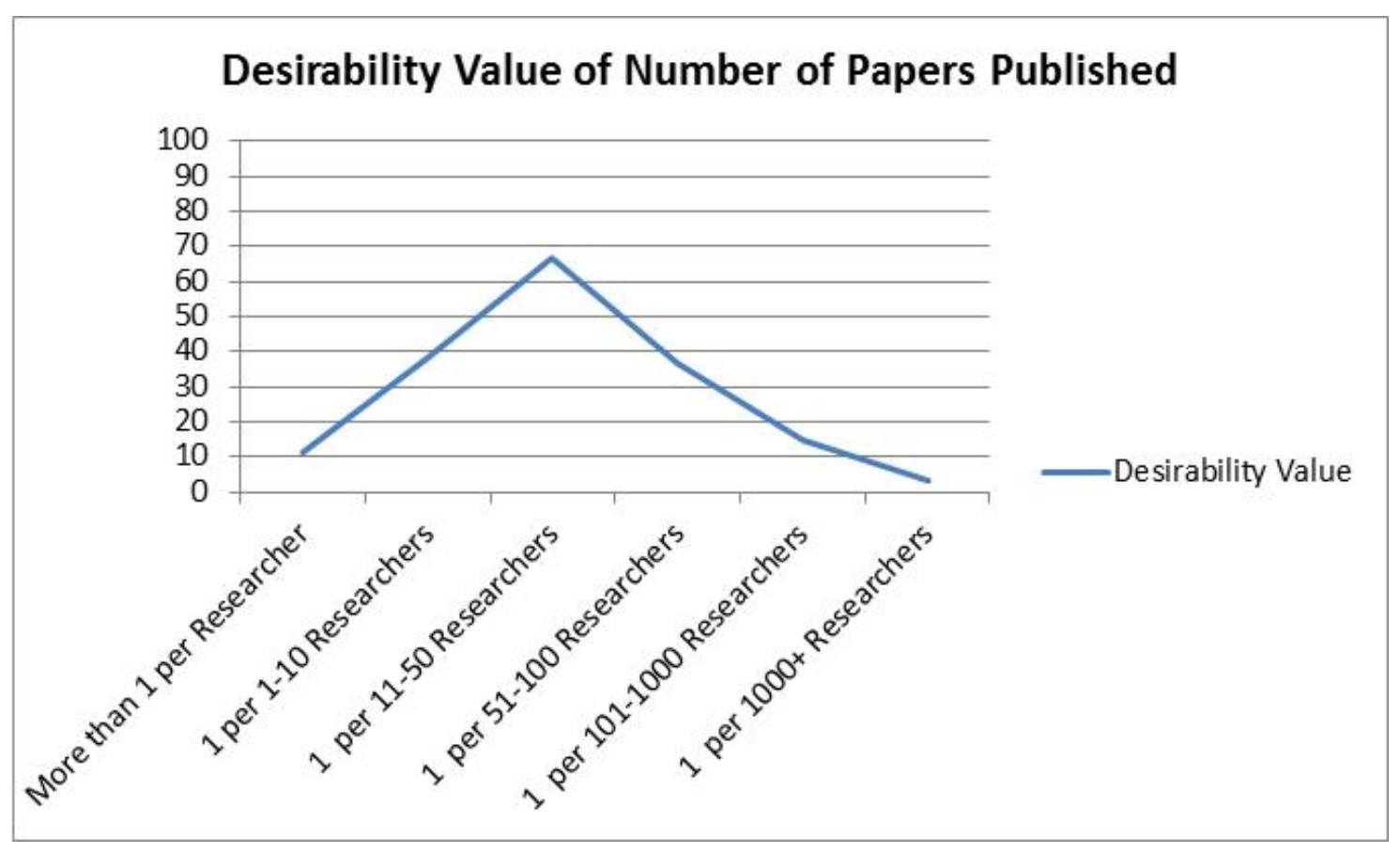

Figure 6.14 The Desirability Value of Number of Papers Published 


\section{Number of Papers Cited}

The intraclass correlation coefficient for number of papers cited is close to 0 with the value of 0.014 . It is extremely low. The computed F-value is 1.073 , while the Fcritical at 0.01 is 4.5556 . The null hypothesis cannot be rejected. It confirms the intraclass correlation coefficient that there is a statistically significant difference among experts regarding number of papers cited.

TABLE 6.47 INTRACLASS CORRELATION COEFFICIENT OF DESIRABILITY VALUE OF NUMBER OF PAPERS CITED

\begin{tabular}{|l|r|r|r|r|r|r|r|}
\hline & \multicolumn{4}{|c|}{ Intraclass Correlation Coefficient } \\
\cline { 4 - 9 } & \multirow{2}{*}{$\begin{array}{c}\text { Intraclass } \\
\text { Correlation }\end{array}$} & \multicolumn{2}{c|}{$99 \%$ Confidence Interval } & \multicolumn{3}{|c|}{ F Test with True Value 0 } \\
\cline { 3 - 9 } & & Lower Bound & Upper Bound & Value & df1 & df2 & Sig \\
\hline Single Measures & $.014^{\mathrm{a}}$ & -.189 & .723 & 1.073 & 5 & 15 & .414 \\
Average Measures & .055 & -1.748 & .913 & 1.073 & 5 & 15 & .414 \\
\hline
\end{tabular}

Two-way random effects model where both people effects and measures effects are random.

a. The estimator is the same, whether the interaction effect is present or not.

b. Type A intraclass correlation coefficients using an absolute agreement definition.

EXP1 was also an outlier in number of papers cited. EXP1's responses contradicted all the other experts. After EXP1 is excluded, the intraclass correlation shows significant improvement to 0.53 . The F-critical at 0.01 is 5.6363. The computed Fvalue excluding EXP1 is 12.872. It means that the null hypothesis can be rejected. There is no statistically significant difference among experts after EXP1 is excluded. The new arithmetic mean that excludes EXP1 was used to create the desirability curve. 
TABLE 6.48 INTRACLASS CORRELATION COEFFICIENT OF DESIRABILITY VALUE OF NUMBER OF PAPERS CITED (EXCLUDING EXP1)

\begin{tabular}{|l|r|r|r|r|r|r|r|}
\hline & \multicolumn{1}{|c|}{ Intraclass Correlation Coefficient } \\
\hline & \multirow{2}{*}{$\begin{array}{c}\text { Intraclass } \\
\text { Correlation }\end{array}$} & \multicolumn{2}{|c|}{$99 \%$ Confidence Interval } & \multicolumn{3}{|c|}{ F Test with True Value 0 } \\
\cline { 3 - 9 } & Lower Bound & Upper Bound & Value & df1 & df2 & Sig \\
\hline Single Measures & $.530^{\mathrm{a}}$ & -.045 & .950 & 12.872 & 5 & 10 & .000 \\
Average Measures & .772 & -.149 & .983 & 12.872 & 5 & 10 & .000 \\
\hline
\end{tabular}

Two-way random effects model where both people effects and measures effects are random.

a. The estimator is the same, whether the interaction effect is present or not.

b. Type A intraclass correlation coefficients using an absolute agreement definition.

TABLE 6.49 DESIRABILITY VALUE - NUMBER OF PAPERS CITED (EXCLUDING EXP1)

\begin{tabular}{|c|c|c|c|c|c|c|}
\hline $\begin{array}{c}\text { Number of } \\
\text { Papers Cited }\end{array}$ & $\begin{array}{c}\text { More than 1 } \\
\text { Per } \\
\text { Researcher }\end{array}$ & $\begin{array}{c}1 \text { Paper per } \\
1-10 \\
\text { Researchers }\end{array}$ & $\begin{array}{c}1 \text { Paper per } \\
11-50 \\
\text { Researchers }\end{array}$ & $\begin{array}{c}1 \text { Paper per } \\
51-100 \\
\text { Researchers }\end{array}$ & $\begin{array}{c}1 \text { Paper per } \\
101-1000 \\
\text { Researchers }\end{array}$ & $\begin{array}{c}1 \text { Paper per } \\
1000+ \\
\text { Researchers }\end{array}$ \\
\hline EXP2 & 20 & 40 & 50 & 60 & 30 & 10 \\
\hline EXP3 & 10 & 20 & 40 & 20 & 6 & 0 \\
\hline EXP4 & 0 & 10 & 40 & 20 & 10 & 0 \\
\hline Mean & 10 & 23.33 & 43.33 & 33.33 & 15.33 & 3.33 \\
\hline
\end{tabular}

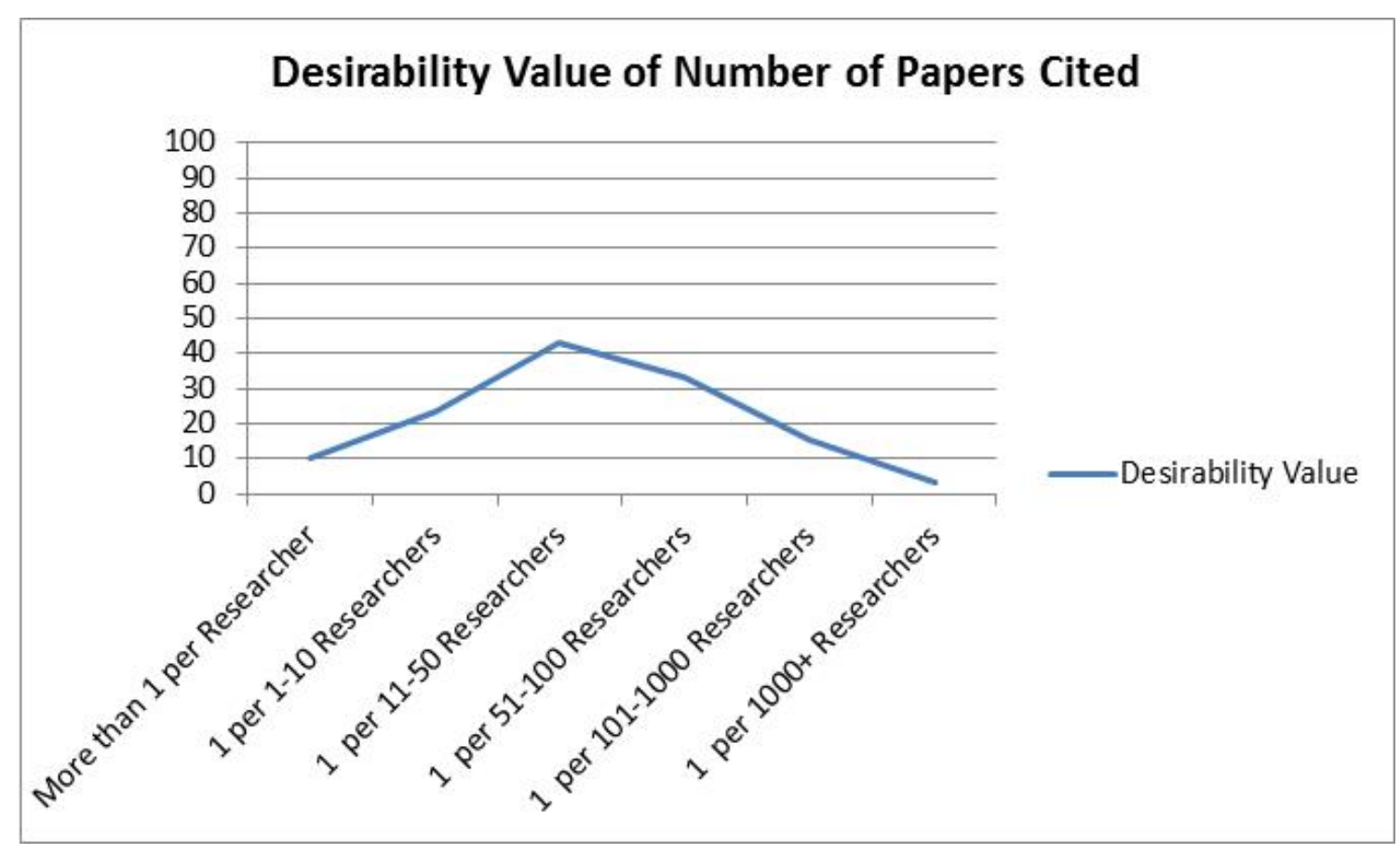

Figure 6.15 The Desirability Value of Number of Papers Cited 


\section{Number of Papers Presented}

The intraclass correlation coefficient for number of papers presented is very low with the value of 0.104 . It is close to 0 . The computed F-value is 1.595 . The F-critical at 0.01 is 4.5556 . The null hypothesis cannot be rejected because the computed F-value is lower than F-critical. Since there is a disagreement among experts, the arithmetic mean from Table 6.30 cannot be used.

TABLE 6.50 INTRACLASS CORRELATION COEFFICIENT OF DESIRABILITY VALUE OF NUMBER OF PAPERS PRESENTED

Intraclass Correlation Coefficient

\begin{tabular}{|l|r|r|r|r|r|r|r|}
\hline & \multirow{2}{*}{$\begin{array}{c}\text { Intraclass } \\
\text { Correlation }\end{array}$} & \multicolumn{2}{|c|}{ 99\% Confidence Interval } & \multicolumn{4}{|c|}{ F Test with True Value 0 } \\
\cline { 3 - 9 } & Lower Bound & Upper Bound & Value & df1 & \multicolumn{1}{c|}{ df2 } & Sig \\
\hline Single Measures & $.104^{\mathrm{a}}$ & -.153 & .794 & 1.595 & 5 & 15 & .221 \\
Average Measures & .318 & -1.133 & .939 & 1.595 & 5 & 15 & .221 \\
\hline
\end{tabular}

Two-way random effects model where both people effects and measures effects are random.

a. The estimator is the same, whether the interaction effect is present or not.

b. Type A intraclass correlation coefficients using an absolute agreement definition.

After the analysis was performed, EXP 1 apparently was an outliner in this case. Similar with previous cases, EXP1 was excluded from the table. After the exclusion, the intraclass correlation coefficient increased significantly to 0.729 . The computed F-value is 8.7, which is higher than F-critical at 0.01 with the value of 5.6363. It means that the null hypothesis can be rejected and there is no statistically significant difference among experts. The new arithmetic means that exclude EXP1 are used to create the desirability curve. 
TABLE 6.51 INTRACLASS CORRELATION COEFFICIENT OF DESIRABILITY VALUE OF NUMBER OF PAPERS PRESENTED (EXCLUDE EXP1)

Intraclass Correlation Coefficient

\begin{tabular}{|l|r|r|r|r|r|r|r|}
\hline & \multirow{2}{*}{$\begin{array}{c}\text { Intraclass } \\
\text { Correlation }\end{array}$} & \multicolumn{2}{|c|}{$99 \%$ Confidence Interval } & \multicolumn{4}{|c|}{ F Test with True Value 0 } \\
\cline { 3 - 9 } & Lower Bound & Upper Bound & Value & df1 & df2 & Sig \\
\hline Single Measures & $.729^{\mathrm{a}}$ & .126 & .976 & 8.700 & 5 & 10 & .002 \\
Average Measures & .890 & .303 & .992 & 8.700 & 5 & 10 & .002 \\
\hline
\end{tabular}

Two-way random effects model where both people effects and measures effects are random.

a. The estimator is the same, whether the interaction effect is present or not.

b. Type A intraclass correlation coefficients using an absolute agreement definition.

TABLE 6.52 DESIRABILITY VALUE - NUMBER OF PAPERS PRESENTED (EXCLUDING EXP1)

\begin{tabular}{|c|c|c|c|c|c|c|}
\hline $\begin{array}{c}\text { Number of } \\
\text { Papers } \\
\text { Presented }\end{array}$ & $\begin{array}{c}\text { More than 1 } \\
\text { Per } \\
\text { Researcher }\end{array}$ & $\begin{array}{c}1 \text { Paper per } \\
1-10 \\
\text { Researchers }\end{array}$ & $\begin{array}{c}1 \text { Paper per } \\
11-50 \\
\text { Researchers }\end{array}$ & $\begin{array}{c}1 \text { Paper per } \\
51-100 \\
\text { Researchers }\end{array}$ & $\begin{array}{c}1 \text { Paper per } \\
101-1000 \\
\text { Researchers }\end{array}$ & $\begin{array}{c}1 \text { Paper per } \\
1000+ \\
\text { Researchers }\end{array}$ \\
\hline EXP2 & 20 & 50 & 60 & 40 & 30 & 20 \\
\hline EXP3 & 30 & 55 & 40 & 35 & 15 & 0 \\
\hline EXP4 & 15 & 35 & 65 & 55 & 30 & 0 \\
\hline Mean & 21.67 & 46.67 & 55.00 & 43.33 & 25.00 & 6.67 \\
\hline
\end{tabular}

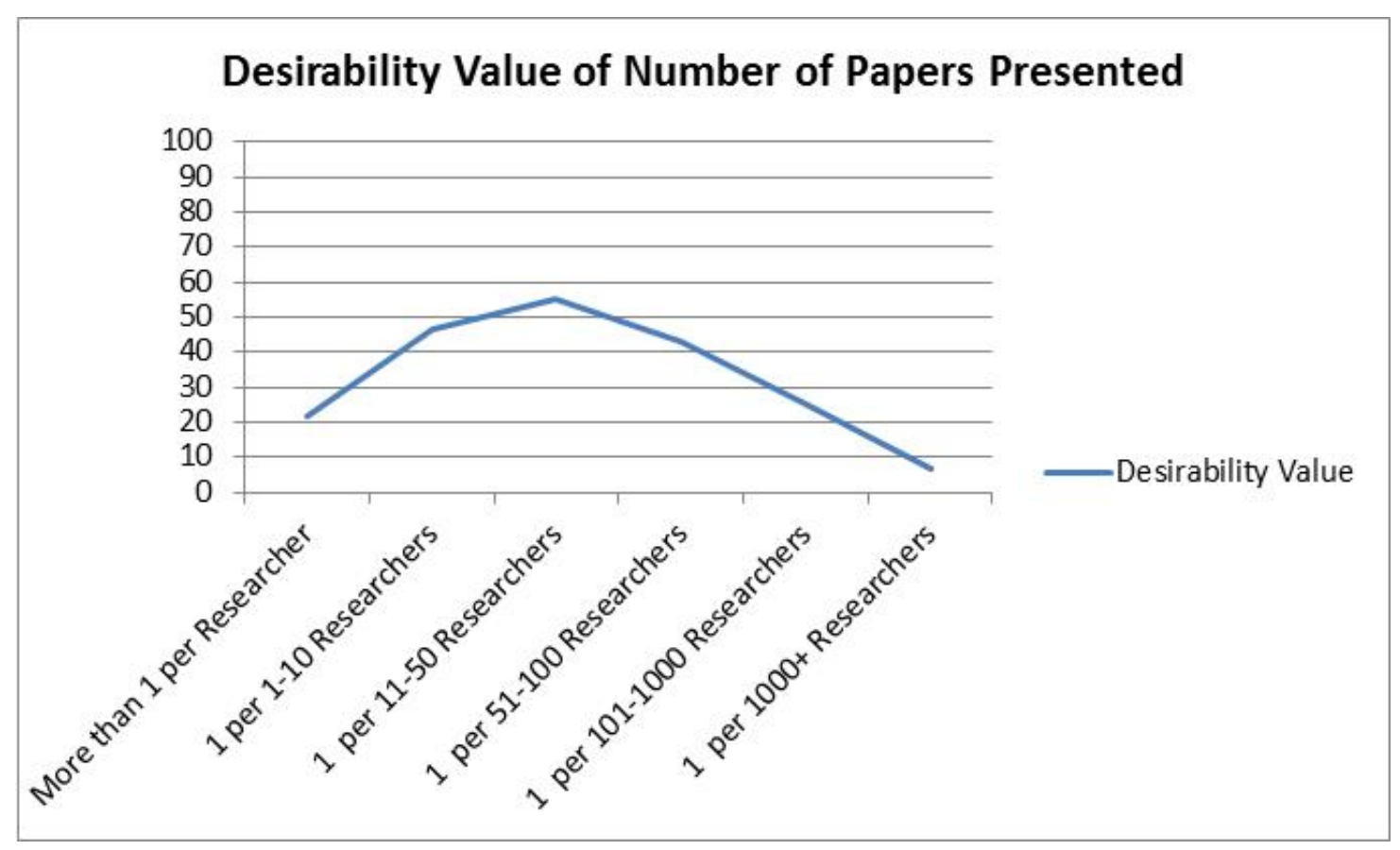

Figure 6.16 The Desirability Value of Number of Papers Presented 


\section{$\underline{\text { Revenue from New Products }}$}

The intraclass correlation coefficient for revenue from new products is fairly high with the value of 0.652 . It is close to 1 . The F-computed is 10.915 , while the F-critical at 0.01 is 3.8549. Since F-critical is lower than F-computed, the null hypothesis can be rejected. There is no statistically significant difference among experts regarding revenue from new products. The arithmetic means of Table 6.31 are used to create the desirability curve.

\section{TABLE 6.53 INTRACLASS CORRELATION COEFFICIENT OF DESIRABILITY VALUE OF} REVENUE FROM NEW PRODUCTS

\begin{tabular}{|l|r|r|r|r|r|r|r|}
\hline \multicolumn{1}{|c|}{ Intraclass Correlation Coefficient } \\
\cline { 4 - 9 } & \multirow{2}{*}{$\begin{array}{c}\text { Intraclass } \\
\text { Correlation }\end{array}$} & \multicolumn{2}{|c|}{$99 \%$ Confidence Interval } & \multicolumn{3}{|c|}{ F Test with True Value 0 } \\
\cline { 3 - 9 } & Lower Bound & Upper Bound & Value & df1 & df2 & Sig \\
\hline Single Measures & $.652^{\mathrm{a}}$ & .223 & .963 & 10.915 & 5 & 25 & .000 \\
Average Measures & .918 & .633 & .994 & 10.915 & 5 & 25 & .000 \\
\hline
\end{tabular}

Two-way random effects model where both people effects and measures effects are random.

a. The estimator is the same, whether the interaction effect is present or not.

b. Type A intraclass correlation coefficients using an absolute agreement definition.

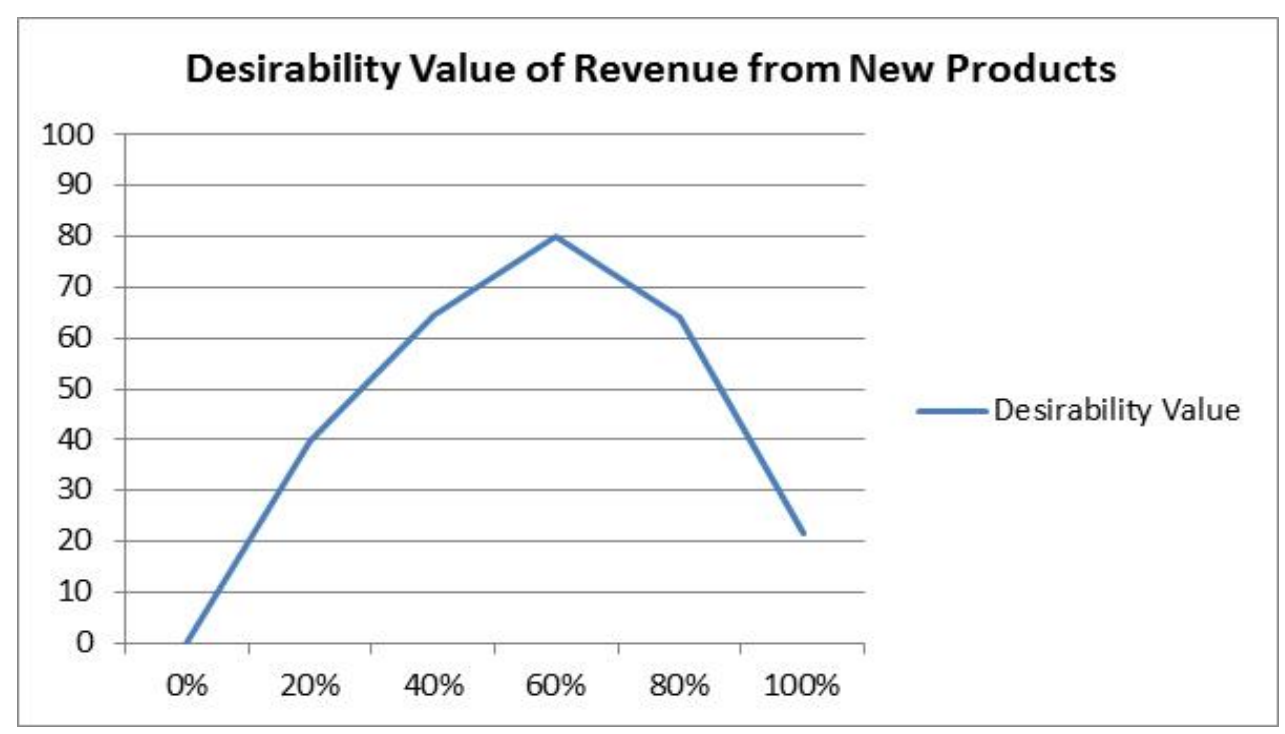

Figure 6.17 The Desirability Value of Revenue from New Products 


\section{$\underline{\text { Market Share of New Products }}$}

The intraclass correlation for market share of new products is high with the value of 0.82 . The F-critical at 0.01 is 3.8549 . The computed F-value is 35.430 . The null hypothesis can be rejected because the computed F-value is higher than F-critical. There is no statistically significant difference among experts, thus the arithmetic means from Table 6.32 are used to create the desirability curve.

TABLE 6.54 INTRACLASS CORRELATION COEFFICIENT OF DESIRABILITY VALUE OF MARKET SHARE OF NEW PRODUCTS

Intraclass Correlation Coefficient

\begin{tabular}{|c|c|c|c|c|c|c|c|}
\hline & \multirow{2}{*}{$\begin{array}{c}\text { Intraclass } \\
\text { Correlation }^{\mathrm{b}}\end{array}$} & \multicolumn{2}{|c|}{$99 \%$ Confidence Interval } & \multicolumn{4}{|c|}{ F Test with True Value 0} \\
\hline & & Lower Bound & Upper Bound & Value & df1 & df2 & Sig \\
\hline Single Measures & $.820^{\mathrm{a}}$ & .484 & .984 & 34.430 & 5 & 25 & .000 \\
\hline Average Measures & .965 & .849 & .997 & 34.430 & 5 & 25 & .000 \\
\hline
\end{tabular}

Two-way random effects model where both people effects and measures effects are random.

a. The estimator is the same, whether the interaction effect is present or not.

b. Type A intraclass correlation coefficients using an absolute agreement definition.

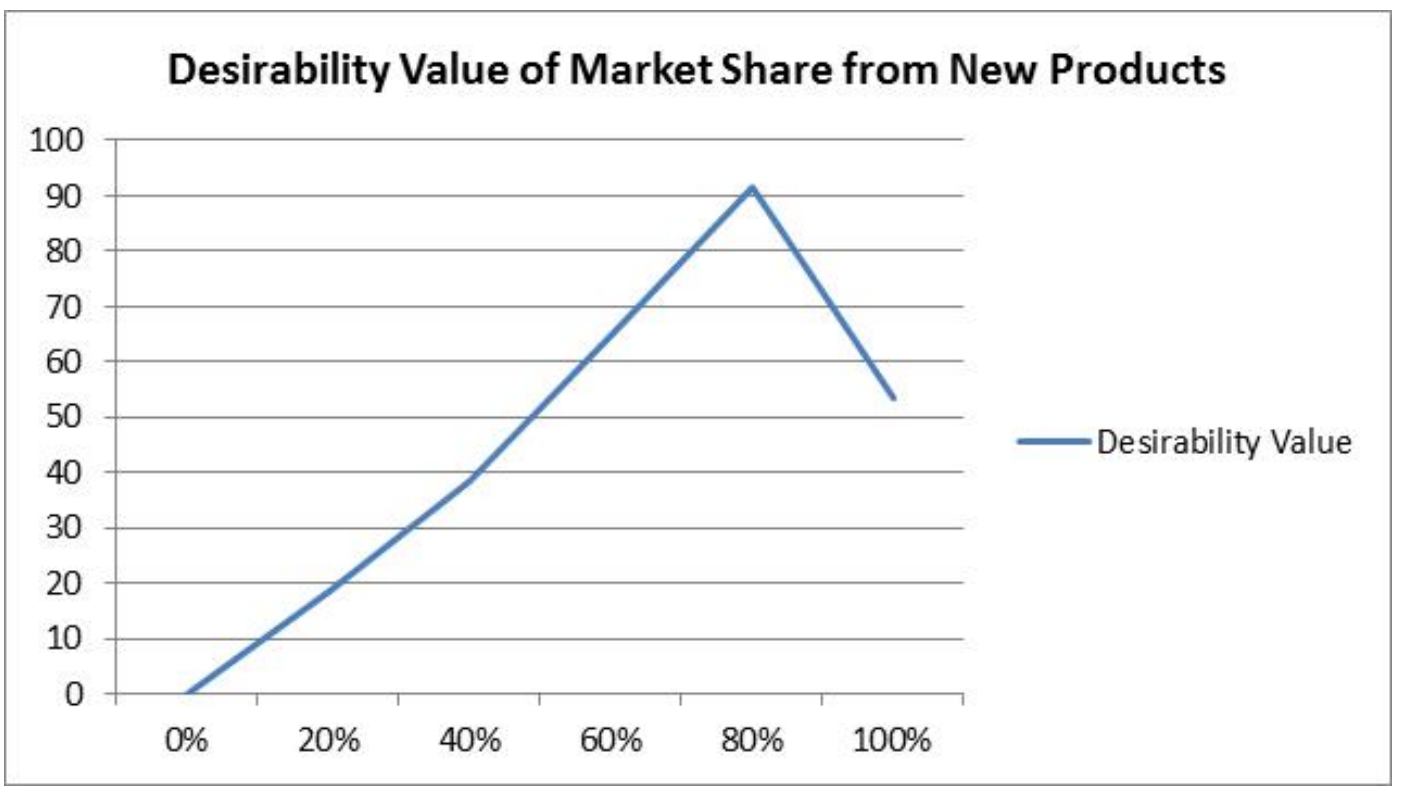

Figure 6.18 The Desirability Value of Market Share from New Products 
The highest possible innovativeness index is not 100 . The most desirable values for many of the sub factors are not at the maximum score of 100 . Thus, by taking the highest desirability value from each sub factors and multiply it with the relative weight of each sub factors will bring the maximum innovativeness index to 76.5 .

\subsection{SENSITIVITY ANALYSIS}

\subsubsection{HDM Sensitivity Analysis}

Sensitivity analysis was performed to find the allowable range of perturbations, tolerance and sensitivity coefficient for output indicators. It shows the allowable range of each output indicator in order to maintain the priority of sub-factors. In this case, the allowable range is to maintain revenue from new products to be the most important output indicator. The results from the sensitivity analysis are presented in Table 6.55.

TABLE 6.55 ALLOWABLE RANGES OF PERTURBATIONS, TOLERANCE AND SENSITIVITY COEFFICIENT FOR OUTPUT INDICATORS TO MAINTAIN REVENUE FROM NEW PRODUCTS AS THE TOP INDICATOR

\begin{tabular}{|l|c|c|c|c|c|c|}
\hline & $\begin{array}{c}\text { Number of } \\
\text { New Products }\end{array}$ & $\begin{array}{c}\text { Number of } \\
\text { Innovation } \\
\text { Awards }\end{array}$ & $\begin{array}{c}\text { Number of } \\
\text { Patents }\end{array}$ & $\begin{array}{c}\text { Revenue from } \\
\text { New Products }\end{array}$ & $\begin{array}{c}\text { Number of } \\
\text { Publications }\end{array}$ & $\begin{array}{c}\text { Market Share } \\
\text { of New } \\
\text { Products }\end{array}$ \\
\hline $\begin{array}{l}\text { Relative } \\
\text { Importance }\end{array}$ & 0.2 & 0.09 & 0.14 & 0.28 & 0.08 & 0.21 \\
\hline $\begin{array}{l}\text { Allowable } \\
\text { ranges of } \\
\text { Perturbations }\end{array}$ & $\begin{array}{c}{[-0.051,} \\
0.0079]\end{array}$ & $\begin{array}{c}{[-0.0092,} \\
0.0433]\end{array}$ & $\begin{array}{c}{[-0.0453,} \\
0.0487]\end{array}$ & $\begin{array}{c}{[-0.0542,} \\
0.72]\end{array}$ & $\begin{array}{c}{[-0.07,} \\
0.0091]\end{array}$ & $\begin{array}{c}{[-0.00798,} \\
0.0517]\end{array}$ \\
\hline Tolerance & {$[0.149,0.2079]$} & $\begin{array}{c}{[0.0808,} \\
0.1333]\end{array}$ & $\begin{array}{c}{[0.0947,} \\
0.1887]\end{array}$ & {$[0.2258,1]$} & {$[0,0.0791]$} & {$[0.202,0.2617]$} \\
\hline $\begin{array}{l}\text { Sensitivity } \\
\text { Coefficient }\end{array}$ & 16.78 & 19.05 & 10.64 & 1.292 & 12.64 & 16.75 \\
\hline
\end{tabular}

From the table above, revenue from new products is very sensitive to almost all other indicators other than itself. Number of innovation awards yielded the highest sensitivity. It can only decrease by -0.0092 or increase by 0.0433 . Any changes in that 
indicator will change the rank of the output indicators and sub-factors. Number of new products and market share of new products are very sensitive with sensitivity coefficients that are close to each other. For number of new products, the allowable range is to decrease by -0.051 or to increase by 0.0079 . Any changes beyond that allowable range will change the rank of the output indicators and sub-factors. Market share of new products has the relative importance of 0.21 . If the relative importance is decreased to 0.202 and increased to 0.2617 , the rank will remain the same. Number of publications has the sensitivity coefficient of 12.64 . The relative importance can be decreased by -0.07 and increased by 0.0091 in order to maintain revenue from new products as the topranked indicator. Number of patents has the sensitivity coefficient of 10.64. As long as the relative importance of number of patents is not decreased below 0.0947 and increased above 0.1887 , the ranking of the output indicators will remain steady. Revenue of new products is the least sensitive compared to all others. It can be decreased to 0.2258 and increased to as high as 1.

\subsubsection{Sensitivity of Individual Ranking}

Individual rankings of the output indicators were presented in the previous section. F-test to test the disagreement was done to find out the statistical significance among the experts regarding the ranking of output indicators. Table 6.56 shows the relative priority of each expert regarding the output indicators' ranking. 
TABLE 6.56 RANKING OF OUTPUT INDICATORS FROM EXPERTS IN EXPERT PANEL 2

\begin{tabular}{|c|c|c|c|c|c|c|}
\hline $\begin{array}{c}\text { Company } \\
\text { Innovativeness } \\
\text { Index }\end{array}$ & $\begin{array}{c}\text { Number of } \\
\text { New } \\
\text { Products }\end{array}$ & $\begin{array}{c}\text { Number of } \\
\text { Innovation } \\
\text { Awards }\end{array}$ & $\begin{array}{c}\text { Number of } \\
\text { Patents }\end{array}$ & $\begin{array}{l}\text { Revenue } \\
\text { from New } \\
\text { Products }\end{array}$ & $\begin{array}{l}\text { Number of } \\
\text { Publications }\end{array}$ & $\begin{array}{c}\text { Market } \\
\text { Share of } \\
\text { New } \\
\text { Products } \\
\end{array}$ \\
\hline EXP1 & 3 & 5.5 & 4 & 1.5 & 5.5 & 1.5 \\
\hline EXP2 & 3.5 & 5 & 3.5 & 1.5 & 6 & 1.5 \\
\hline EXP3 & 3 & 5 & 4 & 1 & 6 & 2 \\
\hline EXP4 & 3.5 & 5 & 2 & 1 & 6 & 3.5 \\
\hline EXP5 & 2 & 5.5 & 4 & 1 & 5.5 & 3 \\
\hline EXP6 & 5 & 3.5 & 3.5 & 2 & 6 & 1 \\
\hline EXP7 & 2.5 & 5 & 4 & 1 & 6 & 2.5 \\
\hline EXP8 & 3 & 6 & 4 & 1 & 5 & 2 \\
\hline EXP9 & 2 & 6 & 4 & 1 & 5 & 3 \\
\hline EXP10 & 1 & 6 & 4 & 2 & 3 & 5 \\
\hline EXP11 & 3.5 & 6 & 1 & 2 & 5 & 3.5 \\
\hline EXP12 & 1 & 5.5 & 3 & 2 & 5.5 & 4 \\
\hline EXP13 & 1 & 4.5 & 3 & 2 & 6 & 4.5 \\
\hline EXP14 & 3 & 5 & 6 & 2 & 4 & 1 \\
\hline EXP15 & 1 & 5 & 4 & 2 & 6 & 3 \\
\hline EXP16 & 4 & 1 & 3 & 2 & 5.5 & 5.5 \\
\hline EXP17 & 3 & 6 & 4 & 1 & 5 & 2 \\
\hline EXP18 & 3 & 6 & 1 & 4 & 5 & 2 \\
\hline EXP19 & 2 & 4 & 5 & 1 & 6 & 3 \\
\hline EXP20 & 5.5 & 3 & 4 & 1 & 5.5 & 2 \\
\hline EXP21 & 5 & 4 & 2 & 1 & 6 & 3 \\
\hline EXP22 & 2.5 & 5.5 & 5 & 1 & 5.5 & 2.5 \\
\hline EXP23 & 2 & 4 & 5.5 & 1 & 5.5 & 3 \\
\hline EXP24 & 5.5 & 3 & 4 & 2 & 5.5 & 1 \\
\hline EXP25 & 4 & 3 & 1 & 2.5 & 5 & 2.5 \\
\hline EXP26 & 3 & 5.5 & 4 & 3 & 5.5 & 1 \\
\hline EXP27 & 3 & 4 & 2 & 5 & 6 & 1 \\
\hline EXP28 & 2 & 6 & 1 & 3 & 4 & 5 \\
\hline EXP29 & 5 & 3 & 4 & 1 & 6 & 2 \\
\hline EXP30 & 4 & 5 & 3 & 1 & 6 & 2 \\
\hline EXP31 & 2 & 6 & 4 & 1 & 5 & 3 \\
\hline EXP32 & 5 & 4 & 3 & 1 & 6 & 3 \\
\hline EXP33 & 2 & 4 & 5 & 1 & 6 & 3 \\
\hline EXP34 & 2 & 5 & 4 & 1 & 6 & 3 \\
\hline EXP35 & 2 & 5.5 & 3.5 & 1 & 5.5 & 3.5 \\
\hline EXP36 & 6 & 2 & 4 & 1 & 5 & 3 \\
\hline
\end{tabular}


The mid-range method is used if two indicators share the same importance. For example, the number of innovation awards and number of publications obtained the same weights from Expert 1. Instead of assigning 5 and 6 to the ranking, mid-ranking, which is 5.5 , is used for both indicators.

After the analysis, the intraclass correlation is relatively high with the value of 0.591. The computed F-value is 44.661, while the F-critical at 0.01 is 3.1235 . Because the computed F-value is higher than the F-critical at 0.01 , it is concluded that there are no statistically significant differences among all experts regarding the ranking of output indicators.

\subsubsection{Sensitivity of Group Ranking}

The ranking of each group was also compared to the ranking from all experts. The ranking of output indicators after the grouping is presented in Table 6.57.

TABLE 6.57 RANKING OF OUTPUT INDICATORS ACCORDING TO DIFFERENT SUB-GROUPS

\begin{tabular}{|c|c|c|c|c|c|c|}
\hline $\begin{array}{c}\text { Company } \\
\text { Innovativeness } \\
\text { Index }\end{array}$ & $\begin{array}{l}\text { Number of } \\
\text { New } \\
\text { Products }\end{array}$ & $\begin{array}{c}\text { Number of } \\
\text { Innovation } \\
\text { Awards }\end{array}$ & $\begin{array}{c}\text { Number } \\
\text { of Patents }\end{array}$ & $\begin{array}{l}\text { Revenue } \\
\text { from New } \\
\text { Products }\end{array}$ & $\begin{array}{l}\text { Number of } \\
\text { Publications }\end{array}$ & $\begin{array}{c}\text { Market } \\
\text { Share of } \\
\text { New } \\
\text { Products }\end{array}$ \\
\hline All 36 Experts & 3 & 5 & 4 & 1 & 6 & 2 \\
\hline $1^{\text {st }}$ Sub-group & 3 & 5 & 4 & 1 & 6 & 2 \\
\hline $2^{\text {nd }}$ Sub-group & 3 & 5 & 4 & 2 & 6 & 1 \\
\hline $3^{\text {rd }}$ Sub-group & 1 & 6 & 3 & 2 & 4.5 & 4.5 \\
\hline $4^{\text {th }}$ Sub-group & 2 & 6 & 1 & 4 & 5 & 3 \\
\hline
\end{tabular}


Analysis was performed to find the disagreement among different sub-groups. The intraclass correlation coefficient is 0.665 , which is relatively high. The computed Fvalue is 9.282 , while the F-critical at 0.01 is 4.1027 . Because the F-critical is lower than the computed F-value, it is concluded that there are no statistically significant differences regarding the ranking of the output indicators by different sub-groups.

\subsection{SIMULATED APPLICATION OF THE MODEL}

To demonstrate the model in this research, five hypothetical companies were established. Five different profiles were developed and measured to give a comprehensive understanding of the model. The scenario is for the time span of the last 3 years. Each company was given different values. The value obtained from the desirability curve was calculated with the relative importance to get the innovativeness index of each company.

Company A is the largest among all with a total of 1000 products on the market in the last 3 years. It has 6000 researchers with total revenues of $\$ 800$ million USD.

Companies B and D are medium-sized companies. Company B has had a total of 150 products on the market in the last 3 years, 250 researchers, and total revenues of $\$ 80$ million USD. Company D has had 120 products on the market in the last 3 years, 800 researchers, and total revenues of \$200 million USD.

Companies $\mathrm{C}$ and $\mathrm{E}$ are small-sized companies. Company $\mathrm{C}$ has had 10 products on the market in the last 3 years, 50 researchers, and total revenues of $\$ 10$ million USD. Company E has had 75 products on the market in the last 3 years, 75 researchers, and $\$ 2$ 
million USD in total revenues. The profiles of the companies are presented in Table 6.58.

Table 6.59 provides the characteristics of each company.

TABLE 6.58 PROFILE OF THE FIVE HYPOTHETICAL COMPANIES

\begin{tabular}{|c|c|c|c|c|c|}
\hline COMPANY & A & B & C & D & E \\
\hline Total Products in the last 3 years & 1000 & 150 & 10 & 120 & 75 \\
\hline Total Researchers & 6000 & 250 & 50 & 800 & 75 \\
\hline Total Revenue (in thousands US\$) & 800,000 & 80,000 & 10,000 & 200,000 & $2 ., 000$ \\
\hline
\end{tabular}

TABLE 6.59 CHARACTERISTICS OF THE FIVE HYPOTHETICAL COMPANIES

\begin{tabular}{|l|c|c|c|c|c|}
\hline \multicolumn{1}{|c|}{ COMPANY } & A & B & C & D & E \\
\hline New Products New to the World & 600 & 24 & 2 & 10 & 6 \\
\hline New Products New to the Company & 800 & 45 & 3 & 18 & 9 \\
\hline Number of Awards & 600 & 20 & 1 & 12 & 7 \\
\hline Number of Honors & 600 & 20 & 4 & 8 & 6 \\
\hline Number of Patents Granted & 600 & 4 & 4 & 8 & 25 \\
\hline Number of Patents Filed & 800 & 4 & 4 & 12 & 30 \\
\hline Number of Patents Cited & 700 & 3 & 4 & 8 & 40 \\
\hline $\begin{array}{l}\text { Revenue from New Products (in } \\
\text { thousands US\$) }\end{array}$ & 480,000 & 160,000 & 3,500 & 20,000 & 400 \\
\hline Number of Papers Published & 50 & 4 & 6 & 72 & 7 \\
\hline Number of Papers Presented & 40 & 2 & 4 & 60 & 7 \\
\hline Number of Papers Cited & 40 & 3 & 10 & 68 & 6 \\
\hline Market Share of New Products & $90 \%$ & $30 \%$ & $60 \%$ & $15 \%$ & $30 \%$ \\
\hline
\end{tabular}

The characteristics of each company above are normalized. Without normalization, large companies lead in all aspects since they always have higher numbers compared to medium and small companies. The purpose of the normalization is to eliminate biases and ambiguity. Table 6.60 shows the performance metrics of the five hypothetical companies after the normalization. 
TABLE 6.60 THE PERFORMANCE METRICS OF THE HYPOTHETICAL COMPANIES

\begin{tabular}{|l|c|c|c|c|c|}
\hline Sub-Factors & A & B & C & D & E \\
\hline $\begin{array}{l}\text { New Products New to the World as } \\
\text { the Percentage of Total Products }\end{array}$ & $60 \%$ & $16 \%$ & $20 \%$ & $8 \%$ & $8 \%$ \\
\hline $\begin{array}{l}\text { New Products New to the Company } \\
\text { as the Percentage of Total Products }\end{array}$ & $80 \%$ & $30 \%$ & $30 \%$ & $15 \%$ & $12 \%$ \\
\hline $\begin{array}{l}\text { The ratio of Number of Awards to } \\
\text { Total Researchers }\end{array}$ & 1 per 10 & 1 per 12 & 1 per 50 & 1 per 66 & 1 per 10 \\
\hline $\begin{array}{l}\text { The ratio of Number of Honors to } \\
\text { Total Researchers }\end{array}$ & 1 per 10 & 1 per 12 & 1 per 12 & 1 per 100 & 1 per 12 \\
\hline $\begin{array}{l}\text { The ratio of Number of Patents } \\
\text { Granted to Total Researchers }\end{array}$ & 1 per 10 & 1 per 62 & 1 per 12 & 1 per 100 & 1 per 3 \\
\hline $\begin{array}{l}\text { The ratio of Number of Patents Filed } \\
\text { to Total Researchers }\end{array}$ & 1 per 7 & 1 per 62 & 1 per 12 & 1 per 66 & 1 per 2 \\
\hline $\begin{array}{l}\text { The ratio of Number of Patents Cited } \\
\text { to Total Researchers }\end{array}$ & 1 per 8 & 1 per 83 & 1 per 12 & 1 per 100 & 1 per 2 \\
\hline $\begin{array}{l}\text { Revenue from New Products as } \\
\text { Percentage of Total Revenue }\end{array}$ & $60 \%$ & $20 \%$ & $35 \%$ & $10 \%$ & $20 \%$ \\
\hline $\begin{array}{l}\text { The ratio of Number of Papers } \\
\text { Published to Total Researchers }\end{array}$ & 1 per 120 & 1 per 62 & 1 per 8 & 1 per 11 & 1 per 10 \\
\hline $\begin{array}{l}\text { The ratio of Number of Papers } \\
\text { Presented to Total Researchers }\end{array}$ & 1 per 150 & 1 per 125 & 1 per 12 & 1 per 13 & 1 per 10 \\
\hline $\begin{array}{l}\text { The ratio of Number of Papers Cited } \\
\text { to Total Researchers }\end{array}$ & 1 per 150 & 1 per 83 & 1 per 5 & 1 per 11 & 1 per 12 \\
\hline Market Share of New Products & $90 \%$ & $30 \%$ & $60 \%$ & $15 \%$ & $30 \%$ \\
\hline
\end{tabular}

Company $\mathrm{A}$ is strong at revenue from new products, market share of new products, new products new to the world, new products new to the company, and number of patents granted. Company A did not do well in number of papers published, presented and cited.

Company B shows strength in number of awards and honors. It is weak in market share of new products. Company $\mathrm{C}$ does not show strength in any of the sub-factors. All the values obtained by company $\mathrm{C}$ are in the middle range.

Company D is strong in number of papers published, presented, and cited. It produced a higher number of papers than the largest company, Company A. However, Company D did not do very well on the rest of the sub-factors. Company E did a good 
job in number of patents granted, filed and cited. The values for the rest of the sub-factors for company E are fairly low.

The desirability values of the performance metrics of sub-factors for each company are then multiplied with the relative weights of the sub-factors with respect to the innovativeness index. The sum of the values shows the innovativeness index of the company. Table 6.61 shows the innovativeness index and ranking of the five hypothetical companies.

TABLE 6.61 THE INNOVATIVENESS INDEX OF THE HYPOTHETICAL COMPANIES

\begin{tabular}{|l|c|c|c|c|c|}
\hline \multirow{2}{*}{ Base-Line } & \multicolumn{5}{c|}{ Company } \\
\cline { 2 - 6 } & A & B & C & D & E \\
\hline Innovativeness Index & 70.6 & 42.4 & 57.1 & 29.87 & 40.35 \\
\hline Ranking & 1 & 3 & 2 & 5 & 4 \\
\hline
\end{tabular}

The results show that Company A is ranked as first with the innovativeness index of 70.6, followed by company C, B, E and D, respectively, with an innovativeness index of 57.1, 42.4, 40.35 and 29.87. For details regarding the calculation, please see Appendix D. Company A which is the most innovative among all, is $92 \%$ of the possible maximum innovativeness.

The experts assigned high importance to revenue from new products, market share of new products, and new products new to the world. Company A excels and receives high scores in those sub-factors. That is the reason why company A takes the first ranking even though its scores were low for number of papers published, presented and cited. In fact, Company A receives the lowest scores in those sub-factors despite 
being the largest company. Since those factors are the least important compared to the others, they did not compromise the ranking of company A.

Company $\mathrm{C}$, which ranks second, does not show significant strength in any of the sub-factors. It receives middling scores in all sub-factors. However, Company $\mathrm{C}$ shows a correspondingly good value in revenue from new products, market share of new products, new products new to the company, and number of patents granted. Being the smallest company did not mean it would be the least innovative. The results show that Company C is at the second ranking because it did relatively well at the sub-factors that are important.

Companies B and $\mathrm{E}$ are in the third and fourth ranking after the calculation. Even though they show strength in some sub-factors, they did not surpass Companies A and C in the ranking because the sub-factors that companies B and E excel at are not the most important sub-factors, according to the experts. Shining in sub-factors that are not the top priorities will not affect the innovativeness index significantly. In contrast, Companies B and E performed ordinarily in the rest of the sub-factors.

Company D shows significant strength in numbers of papers published, presented and cited. It is the strongest among Companies A, B, C, and E. However, outshining others in the sub-factors that have the lowest importance did not bring company $\mathrm{D}$ to the top ranking because it performed poorly in the rest of the sub-factors.

The analysis above shows that innovativeness is not related to the size of the company. If we are looking at the number only, large companies seem to be more productive. Small companies have a disadvantage as the numbers are always significantly lower than big companies. The analysis also shows that focusing on the right sub-factors 
is very important. Shining at particular sub-factors is not necessarily innovative if those sub-factors are perceived as having less weight to assess the innovativeness.

Further analysis is performed to see how the changes affect the ranking of the companies. Two changes are applied for the analysis. The first change is in the relative weights of the output indicator. The second change is in the value of the companies.

\subsubsection{Changes in Relative Importance of the Output Indicators}

The purpose of analysis is to see how the changes in the priorities of the output indicators affect the ranking of five hypothetical companies. Extreme scenarios are applied to demonstrate the functionality of the model. Four different scenarios are developed for the purpose of this analysis.

\section{Scenario 1: Heavy Emphasis on Awards/Honors}

For the first scenario, the allocation of the weight is emphasized heavily for number of innovation awards/honors. The weight of 0.95 is given to number of innovation awards. The remaining weight of 0.05 is divided equally among the rest of the output indicators. The new relative contributions of sub-factors in respect to the innovativeness index are shown in Table 6.62. Table 6.63 shows the ranking of the companies if alternate scenario 1 is applied. 
TABLE 6.62 THE RELATIVE CONTRIBUTION OF SUB-FACTORS TO THE INNOVATIVENESS INDEX -SCENARIO 1

\begin{tabular}{|l|c|c|}
\hline $\begin{array}{l}\text { Output } \\
\text { Indicators }\end{array}$ & $\begin{array}{c}\text { Base-Line } \\
\text { Value }\end{array}$ & $\begin{array}{c}\text { Scenario }-1 \\
\text { Value }\end{array}$ \\
\hline $\begin{array}{l}\text { Number of New } \\
\text { Products }\end{array}$ & 0.2 & 0.01 \\
\hline $\begin{array}{l}\text { Number of Innovation } \\
\text { Awards }\end{array}$ & 0.09 & 0.95 \\
\hline Number of Patents & 0.14 & 0.01 \\
\hline $\begin{array}{l}\text { Revenue From New } \\
\text { Products }\end{array}$ & 0.28 & 0.01 \\
\hline Number of Publications & 0.07 & 0.01 \\
\hline $\begin{array}{l}\text { Market Share of New } \\
\text { Products }\end{array}$ & 0.21 & 0.01 \\
\hline
\end{tabular}

TABLE 6.63 THE INNOVATIVENESS INDEX OF HYPOTHETICAL COMPANIES -SCENARIO 1

\begin{tabular}{|l|c|c|c|c|c|}
\hline \multirow{2}{*}{ Scenario - 1 } & \multicolumn{5}{|c|}{ Company } \\
\cline { 2 - 6 } & $\mathrm{A}$ & $\mathrm{B}$ & $\mathrm{C}$ & $\mathrm{D}$ & $\mathrm{E}$ \\
\hline Innovativeness Index & 41.287 & 58.965 & 50.286 & 42.0754 & 40.053 \\
\hline Ranking & 4 & 1 & 2 & 3 & 5 \\
\hline
\end{tabular}

If scenario 1 is applied, Company $\mathrm{B}$, which was originally at the 3 rd ranking, rises to the 1 st ranking. It only makes sense because company $\mathrm{B}$ has the highest value for number of awards and number of honors. Those two sub-factors have the highest priority weights compared to other sub-factors.

Company A, which was at the first ranking, declined to the 4th ranking because it did not do very well in number of awards and honors. Even though company A excels at the rest of the sub-factors, if those sub-factors are perceived as not being important, it will not translate company A's performance into the most innovative company.

Companies $\mathrm{C}$ and $\mathrm{D}$ are at the $2 \mathrm{nd}$ and 3rd rankings respectively because they had better performances in number of awards and honors than company A. Company $\mathrm{E}$ is now placed at the bottom ranking in scenario 1 since it has poor values in the top-priority sub-factors. 


\section{Scenario 2: Heavy Emphasis on Publications}

For the second scenario, number of publications is considered the dominant output indicator. Extreme weight of 0.95 is assigned to number of publications. The remaining 0.05 is divided equally among number of new products, number of innovation awards, number of patents, revenue from new products, and market share of new products. Table 6.64 shows the relative contribution of scenario 2. Table 6.65 shows the ranking of the companies if alternate scenario 2 is applied.

\section{Table 6.64 THE RELATIVE CONTRIBUTION OF SUB-FACTORS TO THE INNOVATIVENESS} INDEX - SCENARIO 2

\begin{tabular}{|l|c|c|}
\hline $\begin{array}{l}\text { Output } \\
\text { Indicators }\end{array}$ & $\begin{array}{c}\text { Base-Line } \\
\text { Value }\end{array}$ & $\begin{array}{c}\text { Scenario - 2 } \\
\text { Value }\end{array}$ \\
\hline Number of New Products & 0.2 & 0.01 \\
\hline $\begin{array}{l}\text { Number of Innovation } \\
\text { Awards }\end{array}$ & 0.09 & 0.01 \\
\hline Number of Patents & 0.14 & 0.01 \\
\hline $\begin{array}{l}\text { Revenue from New } \\
\text { Products }\end{array}$ & 0.28 & 0.01 \\
\hline Number of Publications & 0.07 & 0.95 \\
\hline $\begin{array}{l}\text { Market Share of New } \\
\text { Products }\end{array}$ & 0.21 & 0.01 \\
\hline
\end{tabular}

Table 6. 65 THE INNOVATIVENESS INDEX OF HYPOTHETICAL COMPANIES - SCENARIO 2

\begin{tabular}{|l|c|c|c|c|c|}
\hline \multirow{2}{*}{ Scenario - } & \multicolumn{5}{c|}{ Company } \\
\cline { 2 - 6 } & $\mathrm{A}$ & $\mathrm{B}$ & $\mathrm{C}$ & $\mathrm{D}$ & $\mathrm{E}$ \\
\hline Innovativeness Index & 19.761 & 28.415 & 42.766 & 56.401 & 31.311 \\
\hline Ranking & 5 & 4 & 2 & 1 & 3 \\
\hline
\end{tabular}

If scenario 2 is applied, drastic changes happen in the ranking of the companies.

Company D, which was at the bottom of the ranking, escalates to the 1st ranking. Company A, which was at the first ranking, drops to the bottom ranking. The order of the 
ranking is reasonable if we look at the value of those companies in number of paper published, presented and cited. The values of all companies in these three sub-factors contribute to innovativeness.

Company D has the highest value among all the companies in the three subfactors. It leads the competition by a wide margin. The 2 nd ranking is company $\mathrm{C}$. Companies $\mathrm{E}$ and $\mathrm{B}$ are at the 3rd and 4th places. Company A has the lowest value in those sub-factors, which placed it at the 5th ranking.

\section{$\underline{\text { Scenario 3: Heavy Emphasis on Patents }}$}

In the third scenario, number of patents is considered the dominant output indicator. A weight of 0.95 is assigned to number of patents. The remaining 0.05 is distributed equally to the rest of the output indicators. Table 6.66 shows the relative weights of the sub-factors with respect to the innovativeness index. Table 6.67 shows the ranking of the companies if scenario 3 is applied.

TABLE 6.66 THE RELATIVE CONTRIBUTION OF SUB-FACTORS TO THE INNOVATIVENESS INDEX - SCENARIO 3

\begin{tabular}{|l|c|c|}
\hline $\begin{array}{l}\text { Output } \\
\text { Indicators }\end{array}$ & $\begin{array}{c}\text { Base-Line } \\
\text { Value }\end{array}$ & $\begin{array}{c}\text { Scenario }-3 \\
\text { Value }\end{array}$ \\
\hline $\begin{array}{l}\text { Number of New } \\
\text { Products }\end{array}$ & 0.2 & 0.01 \\
\hline $\begin{array}{l}\text { Number of Innovation } \\
\text { Awards }\end{array}$ & 0.09 & 0.01 \\
\hline Number of Patents & 0.14 & 0.95 \\
\hline $\begin{array}{l}\text { Revenue from New } \\
\text { Products }\end{array}$ & 0.28 & 0.01 \\
\hline Number of Publications & 0.07 & 0.01 \\
\hline $\begin{array}{l}\text { Market Share of New } \\
\text { Products }\end{array}$ & 0.21 & 0.01 \\
\hline
\end{tabular}


TABLE 6.67 THE INNOVATIVENESS INDEX OF HYPOTHETICAL COMPANIES - SCENARIO 3

\begin{tabular}{|l|c|c|c|c|c|}
\hline \multirow{2}{*}{ Scenario - 3 } & \multicolumn{5}{c|}{ Company } \\
\cline { 2 - 6 } & $\mathrm{A}$ & $\mathrm{B}$ & $\mathrm{C}$ & $\mathrm{D}$ & $\mathrm{E}$ \\
\hline Innovativeness Index & 69.487 & 47.027 & 59.686 & 44.9894 & 69.475 \\
\hline Ranking & 1 & 4 & 3 & 5 & 2 \\
\hline
\end{tabular}

In scenario 3, the 1st and 5th ranking stay the same. The big surprise is Company E, which was previously at 4 th place and is now at 2nd place with an innovativeness index of 69.475. Companies A and E come very close with only a 0.012 difference in the innovativeness index. Even though company E still leads in number of patents filed, the remaining sub-factors for company A are higher compared to company E. Thus, company A has the higher innovativeness index compared to $\mathrm{E}$.

Companies $\mathrm{C}, \mathrm{D}$, and $\mathrm{E}$ are at the 3rd, 4th and 5th ranking respectively. Company C shows a relatively strong value in number of patents granted, filed and cited. Company D performed fairly well in these three sub-factors. However, the values are still the lowest among them all, thus the ranking of company D remains the same at the bottom ranking.

Unlike other scenarios, the gap of the innovativeness index for companies A-E is not widespread since the values for the companies are fairly close to each other.

\section{$\underline{\text { Scenario 4: Reversed Priorities }}$}

For this scenario, the relative importance of the output indicators from the highest to the lowest is reversed in order to see if the ranking is affected significantly. Table 6.68 shows the relative weights of the sub-factors in respect to the innovativeness index in scenario 4 . 
TABLE 6.68 THE RELATIVE CONTRIBUTION OF SUB-FACTORS TO THE INNOVATIVENESS

INDEX - SCENARIO 4

\begin{tabular}{|l|c|c|}
\hline $\begin{array}{l}\text { Output } \\
\text { Indicators }\end{array}$ & $\begin{array}{c}\text { Base-Line } \\
\text { Value }\end{array}$ & $\begin{array}{c}\text { Scenario }-4 \\
\text { Value }\end{array}$ \\
\hline Number of New Products & 0.2 & 0.14 \\
\hline Number of Innovation Awards & 0.09 & 0.21 \\
\hline Number of Patents & 0.14 & 0.2 \\
\hline Revenue from New Products & 0.28 & 0.07 \\
\hline Number of Publications & 0.07 & 0.28 \\
\hline Market Share of New Products & 0.21 & 0.09 \\
\hline
\end{tabular}

TABLE 6.69 THE INNOVATIVENESS INDEX OF HYPOTHETICAL COMPANIES - SCENARIO 4

\begin{tabular}{|l|c|c|c|c|c|}
\hline \multirow{2}{*}{ Scenario - 4 } & \multicolumn{5}{|c|}{ Company } \\
\cline { 2 - 6 } & $\mathrm{A}$ & $\mathrm{B}$ & $\mathrm{C}$ & $\mathrm{D}$ & $\mathrm{E}$ \\
\hline Innovativeness Index & 50.912 & 42.498 & 51.784 & 41.4002 & 41.418 \\
\hline Ranking & 2 & 3 & 1 & 5 & 4 \\
\hline
\end{tabular}

If the relative importance of the output indicators is reversed, Company $\mathrm{C}$ rises to the 1st ranking with 51.784. Company A comes in 2nd in the ranking with a very close innovative index of 50.912. Companies B, E and D become in 3rd, 4th, and $5^{\text {th }}$, respectively.

The combination of high relative importance with high value and low relative importance with low value is the reason why the gap of the innovativeness indexes of the 1 st and the 5 th ranking is very obvious (the gap is 40.73 ). In contrast, scenario 4 shows the combination of high relative importance with low values and low relative importance with high value, which brings the innovativeness index of the 1st and the 5th ranking close to each other (the gap is 10.3838). 


\subsubsection{Changes in the Performance Metrics of the Companies}

The purpose of this analysis is to see how alterations of the values of the companies change their innovativeness indices. There are numerous changes that can be applied to see if the rankings of the five hypothetical companies will change radically. For the purpose of the demonstration, three different scenarios were developed. Despite being a small number, the scenarios cover various types of changes and provide an indepth understanding of the model.

\section{Scenario 5: Changes in Company A's Performance}

In this scenario, assume that the market share of company A plunges to $20 \%$. There is a significant reduction in the percentage of market share. Table 6.70 shows the innovativeness index of company A after the changes in market share.

TABLE 6.70 COMPANY A WITH CHANGES IN PERFORMANCE METRICS - SCENARIO 5

\begin{tabular}{|c|c|c|}
\hline \multirow[t]{2}{*}{ Sub-Factors } & \multicolumn{2}{|c|}{ COMPANY A } \\
\hline & $\begin{array}{c}\text { Base-Line } \\
\text { Performance Metrics }\end{array}$ & $\begin{array}{c}\text { Scenario } 5 \\
\text { Performance Metrics }\end{array}$ \\
\hline New Products New to the World & 600 & 600 \\
\hline New Products New to the Company & 800 & 800 \\
\hline Number of Awards & 600 & 600 \\
\hline Number of Honors & 600 & 600 \\
\hline Number of Patents Granted & 600 & 600 \\
\hline Number of Patents Filed & 800 & 800 \\
\hline Number of Patents Cited & 700 & 700 \\
\hline Revenue from New Products & 480,000 & 480,000 \\
\hline Number of Papers Published & 50 & 50 \\
\hline Number of Papers Presented & 40 & 40 \\
\hline Number of Papers Cited & 40 & 40 \\
\hline Market Share of New Products & $90 \%$ & $20 \%$ \\
\hline Innovativeness Index & 70.6 & 55.9 \\
\hline Ranking & 1 & 2 \\
\hline
\end{tabular}


In Table 6.70, there was only one change in market share of new products from Company A, but that change affected the innovativeness index significantly. The original innovativeness index of Company A was 70.6. After the change, it dropped to 55.9. It is no longer at the 1st ranking. If the innovativeness of other companies is taken into consideration, Company $\mathrm{C}$, which was previously at the 2 nd ranking with 57.1 , is now at the 1st ranking. It makes sense because market share of new products is the second most important sub-factor in respect to the innovativeness index. Even a minor change in market share of new products has a noteworthy impact on the innovativeness index. 


\section{Scenario 6: Changes in Company E's Performance}

In scenario 2, suppose that company E wants to increase its innovativeness. It is currently at the 4th ranking (second from the last) with an innovativeness index of 40.35 . Company E decides to place full emphasis on the number of papers published, presented and cited. Table 6.71 shows the innovativeness index of Company $\mathrm{E}$ if the performance metrics for the papers presented, published and cited changes.

TABLE 6.71 COMPANY E WITH THE CHANGES IN PERFORMACE METRICS - SCENARIO 6

\begin{tabular}{|c|c|c|}
\hline \multirow[t]{2}{*}{ Sub-Factors } & \multicolumn{2}{|c|}{ COMPANY E } \\
\hline & $\begin{array}{c}\text { Base-Line } \\
\text { Performance Metrics }\end{array}$ & $\begin{array}{c}\text { Scenario } 6 \\
\text { Performance Metrics }\end{array}$ \\
\hline New Products New to the World & 6 & 6 \\
\hline New Products New to the Company & 9 & 9 \\
\hline Number of Awards & 7 & 7 \\
\hline Number of Honors & 6 & 6 \\
\hline Number of Patents Granted & 25 & 25 \\
\hline Number of Patents Filed & 30 & 30 \\
\hline Number of Patents Cited & 40 & 40 \\
\hline Revenue from New Products & 400 & 400 \\
\hline Number of Papers Published & 7 & 50 \\
\hline Number of Papers Presented & 7 & 60 \\
\hline Number of Papers Cited & 6 & 45 \\
\hline Market Share of New Products & $30 \%$ & $30 \%$ \\
\hline Innovativeness Index & 40.35 & 41.4 \\
\hline Ranking & 4 & 4 \\
\hline
\end{tabular}

In this scenario, company $\mathrm{E}$ went the extra mile to increase number of papers published, number of papers presented and number of papers cited. The value of these sub-factors increased significantly. However, the innovativeness index increased only by 
1.05. The combination of those sub-factors does not have as large an impact as the changes in market share of new products because number of papers published, presented and cited have the lowest priorities with considerably low weights. Any changes in those sub-factors will not have a great impact on the innovativeness index. If company $\mathrm{E}$ desires to increase its innovativeness index, it should focus on increasing the value of top-priority sub-factors instead of several sub-factors that have low priorities. 


\section{Scenario 7: Changes in Company D's Performance}

In this scenario, company D is keen to increase its innovativeness. It realizes that compared to all other companies in the same industry, it has the lowest innovativeness index. Thus, company D puts a lot of effort on increasing revenue from new products and market share of new products. Table 6.72 shows the innovativeness index of Company D if it successfully increases its performance metrics in revenue from new products and market share of new products.

TABLE 6.72 DESIRABILITY VALUE COMPANY D WITH THE CHANGES IN VALUES SCENARIO 7

\begin{tabular}{|l|c|c|}
\hline \multirow{2}{*}{ Sub-Factors } & \multicolumn{2}{c|}{ COMPANY D } \\
\cline { 2 - 3 } & $\begin{array}{c}\text { Base-Line } \\
\text { Performance Metrics }\end{array}$ & $\begin{array}{c}\text { Scenario 7 } \\
\text { Performance Metrics }\end{array}$ \\
\hline New Products New to the World & $\mathbf{1 0}$ & $\mathbf{7 2}$ \\
\hline New Products New to the Company & 12 & 12 \\
\hline Number of Awards & 8 & 8 \\
\hline Number of Honors & 8 & 12 \\
\hline Number of Patents Granted & 12 & 8 \\
\hline Number of Patents Filed & 8 & $\mathbf{1 2 0}$ Million \\
\hline Number of Patents Cited & $\mathbf{2 0}$ Million & $\mathbf{7 2}$ \\
\hline Revenue from New Products & 72 & 60 \\
\hline Number of Papers Published & 60 & 68 \\
\hline Number of Papers Presented & 68 & $\mathbf{9 0 \%}$ \\
\hline Number of Papers Cited & $\mathbf{1 5 \%}$ & $\mathbf{7 0 . 7 2}$ \\
\hline Market Share of New Products & $\mathbf{2 9 . 8 7}$ & 1 \\
\hline Innovativeness Index & 5 & \\
\hline Ranking & & 8 \\
\hline
\end{tabular}

As shown in Table 6.72, the innovativeness index of company D increased significantly from 29.87 to 70.72 . In fact, company $\mathrm{D}$ will be at the $1^{\text {st }}$ ranking, 
surpassing all the other companies, if it successfully increases its revenue from new products, market share of new products, new products new to the world and new products new to the company. It is a logical conclusion since those four sub-factors are among the ones with highest relative contribution to the innovativeness index. This scenario demonstrates the importance of focusing on the right sub-factors to increase innovativeness. It is not essential to increase as many sub-factors as possible if those subfactors are not perceived as contributing highly to the innovativeness.

From the analysis above, it is concluded that focusing on the most significant subfactors is critical. A company needs to understand which sub-factors have the highest contributions to the innovativeness and which sub-factors barely have an impact. The weights assigned to each sub-factor provide guidelines and insights for companies to understand what is perceived as innovative. A company can utilize the model to identify which areas are strong and which areas still need improvement. The model also provides insights for a company to catch up with its competitors and maintain its position in the market. The model helps a company to eliminate unnecessary actions by being too focused on low-priority sub-factors, for example: eliminating unnecessary expenditures o resources. Finally, the model helps companies to plan on resource allocations. The resources should be allocated to actions that increase the value of sub-factors with high priority weights.

\subsubsection{Innovativeness Index of Intel and AMD}

The model was implemented in a case study to demonstrate it in the real situation. Intel and AMD were used for this purpose. Both companies are in semiconductor 
industry. The data used for Intel and AMD included not all the product lines, but only notebook processors, desktop processors and server processors to make a consistent comparison between the two companies

Table 6.73 shows the profiles of Intel and AMD. Some of the values are left empty because the data are unavailable.

TABLE 6.73 PROFILES OF INTEL AND AMD

\begin{tabular}{|l|c|c|}
\hline \multicolumn{1}{|c|}{ COMPANY } & Intel & AMD \\
\hline Total Products in the last 3 years [197] & 530 & 275 \\
\hline Total Researchers [198][199] & 1000 & 177 \\
\hline Total Revenue (in thousands US\$) & 103.1 Billion & 11.08 Billion \\
\hline New Products New to the World [197] & 53 & 36 \\
\hline New Products New to the Company [197] & 422 & 160 \\
\hline Number of Awards [200][201] & 37 & 25 \\
\hline Number of Honors [200][201] & Data not available & Data not available \\
\hline Number of Patents Granted [202] & 550 & 100 \\
\hline Number of Patents Filed [202] & 773 & 368 \\
\hline Number of Patents Cited [202] & Data not available & Data not available \\
\hline Revenue from New Products [203] & 91.759 Billion & 7.867 Billions \\
\hline Number of Papers Published [204] & 3192 & 313 \\
\hline Number of Papers Presented [204] & Data not available & Data not available \\
\hline Number of Papers Cited [204] & Data not available & Data not available \\
\hline Market Share of New Products [205] & $62.3 \%$ & $21.3 \%$ \\
\hline
\end{tabular}

The values from table 6.73 were used to define the performance metrics of Intel and AMD. Table 6.74 presents the performance metrics corresponding to the sub-factors in the model. 
TABLE 6.74 THE PERFORMANCES METRICS OF INTEL AND AMD

\begin{tabular}{|l|c|c|}
\hline \multicolumn{1}{|c|}{ Sub-Factors } & Intel & AMD \\
\hline $\begin{array}{l}\text { New Products New to the World as the Percentage } \\
\text { of Total Products }\end{array}$ & $10 \%$ & $13 \%$ \\
\hline $\begin{array}{l}\text { New Products New to the Company as the } \\
\text { Percentage of Total Products }\end{array}$ & $79 \%$ per 27 & 1 per 7 \\
\hline $\begin{array}{l}\text { The ratio of Number of Awards to Total } \\
\text { Researchers }\end{array}$ & Data not available & Data not available \\
\hline $\begin{array}{l}\text { The ratio of Number of Honors to Total } \\
\text { Researchers }\end{array}$ & 1 per 2 & 1 per 2 \\
\hline $\begin{array}{l}\text { The ratio of Number of Patents Granted to Total } \\
\text { Researchers }\end{array}$ & 1 per 2 & $>1$ \\
\hline $\begin{array}{l}\text { The ratio of Number of Patents Filed to Total } \\
\text { Researchers }\end{array}$ & Data not available \\
\hline $\begin{array}{l}\text { The ratio of Number of Patents Cited to Total } \\
\text { Researchers }\end{array}$ & Data not available \\
\hline $\begin{array}{l}\text { Revenue from New Products as Percentage of Total } \\
\text { Revenue }\end{array}$ & $>1$ & $42 \%$ \\
\hline $\begin{array}{l}\text { The ratio of Number of Papers Published to Total } \\
\text { Researchers }\end{array}$ & Data not available \\
\hline $\begin{array}{l}\text { The ratio of Number of Papers Presented to Total } \\
\text { Researchers }\end{array}$ & Data not available \\
\hline $\begin{array}{l}\text { The ratio of Number of Papers Cited to Total } \\
\text { Researchers }\end{array}$ & Datable & Data not available \\
\hline Market Share of New Products & $1.3 \%$ \\
\hline
\end{tabular}

Intel shows strength in the revenue from new products and market share of new products. Those indicators are the top indicators according to the experts. AMD shows a slightly better performance in number of new products new to the world and number of innovation awards. The performance metrics were multiplied by the relative weights of the corresponding sub-factors to obtain the innovativeness index. Table 6.75 shows the innovativeness index of each company.

TABLE 6.75 THE INNOVATIVENESS INDEX OF INTEL AND AMD

\begin{tabular}{|l|c|c|}
\hline \multirow{2}{*}{ Base-Line } & \multicolumn{2}{|c|}{ Company } \\
\cline { 2 - 3 } & Intel & AMD \\
\hline Innovativeness Index & 56.7 & 42.11 \\
\hline
\end{tabular}


The possible maximum score of innovativeness index in this research is 76.5 . However, because some of the data are not available in evaluating the innovativeness of Intel and AMD, the highest possible value for this illustration is 70.9. In this case Intel's innovativeness index is at $80 \%$ of the highest possible level, AMD's is at $60 \%$ of the highest possible level.

\subsection{SUMMARY OF THE RESEARCH}

The results obtained from the experts, the simulated application and the implementation of the case study can be summarized as follows:

1. The objective of developing a decision model and metrics for measuring the innovativeness of a company in the semiconductor industry has been fulfilled.

2. The strategy of getting assistance from the experts in the three expert panels assisted in building the model, populating it with quantified judgments for innovation indicators and sub-factors, and developing desirability values for performance measurement level for each sub-factor has been successfully implemented.

3. No statistically significant differences have been found among experts regarding the importance of output indicators and sub-factors. Revenue of new products (0.28), market share of new products $(0.21)$, and number of new products new to the world by a company $(0.20)$ are perceived as the top 3 indicators to assess the innovativeness of a company in the semiconductor industry. Number of papers 
cited (0.01), number of papers presented (0.02), and number of patents cited (0.02) are the lowest 3 of all the indicators according to the experts.

4. No statistically significant differences for the desirability values of the number of new products new to the world, new to the company, number of patents granted, filed, cited, revenue from new products and market share of new products have been found.

5. Statistically significant differences for the desirability values of number of innovation awards, innovation honors, number of papers published, presented and cited have been found. However, agreement has been reached by excluding one of the experts who was the outlier.

6. After the sensitivity analysis was performed, the number of innovation awards has been identified as the most sensitive indicator with the allowable range of perturbations between -0.0453 and 0.0487 . Even though revenue from new products is the top indicator according to the experts, it has been found as having the least sensitivity compared to other indicators. It can be decreased by -0.0542 and increased by 0.72 without changing the results.

7. The simulated application of the model shows that focusing on the right indicators will help company to be innovative. Regardless of the size, companies that focus on the sub-factors with highest relative importance obtain a better innovativeness index. Even though a company performs extremely well in some sub-factors, if those sub-factors do not have as high importance, the innovativeness index will not be affected significantly. 
8. The Intel and AMD case study shows that Intel is more innovative than AMD. Intel performs better in sub-factors that have high relative importance in respect to the innovativeness index.

9. The model gives an insight to both Intel and AMD on which areas each one is still lacking. Both companies can refer to the model and focus on the sub-factors that have high relative importance for increasing their innovativeness index.

\subsection{VALIDATION}

There are three types of validation implemented in this research. They are construct validity, content validity and criteria-related validity. The process and purpose of the validities are explained as follows:

\subsubsection{Construct Validity}

Construct validity refers to the degree to which the construct of the model is accurate and has the ability to perform the function, in this case as the measurement tool.

The first step of the construct validity was executed through a literature review. A number of indicators and sub-factors were identified and constructed into the model.

The second step was soliciting the opinions of faculty members, $\mathrm{PhD}$ students and potential experts for this research.

Through the series of actions above, the elements were constructed into a hierarchical decision model (HDM). The final construct was validated in the sense that it does not have differences in opinions from diverse group of reviewers. 


\subsubsection{Content Validity}

Content validity refers to the degree to which the elements in the model measure what they are supposed to measure, as well as the readiness of the instruments to collect the data from the respondents.

Experts in expert panel 1 were asked to verify if the elements in the model are good indicators to measure innovativeness. Content validity eliminates irrelevant elements that have the potential to create biases in the measurement.

Web-based instruments to verify the content (elements) in the model were developed to facilitate the process.

Hierarchical Decision Model (HDM) software was developed to collect the data from the experts. Before the instruments were distributed to the experts, they were tested by a small group of experts ( $\mathrm{PhD}$ students, faculty members, potential experts). The software was also verified by some students who used it for projects.

Through the series of actions above, the contents (elements) were verified and the readiness of the instruments to collect the data was also confirmed. The content was validated in the sense of its being appropriate and ready for the data collection.

\subsubsection{Criterion-related Validity}

Criteria related validity refers to the degree to which the performance of the model reflects the performance in a real-life situation. In other words, the results obtained from the model are appropriate, accurate and valid.

Hypothetical companies were developed to test the model. After the results were

obtained, they were presented to the experts. The experts examined whether the results of 
the model were acceptable and valid. The experts were also asked to verify the generalizability of the model. The experts verified that the results from the model were appropriate and valid. They expressed their interest in applying the model to their companies in a real-life setting.

The results of the criterion-related validity were that the model was appropriate and valid. 


\section{CHAPTER 7: DISCUSSION}

\subsection{CONCLUSIONS AND CONTRIBUTIONS}

Figure 7.1 presents the research streams and the primary findings of innovation measurement from the literature review. Based on the findings, several gaps were also identified.
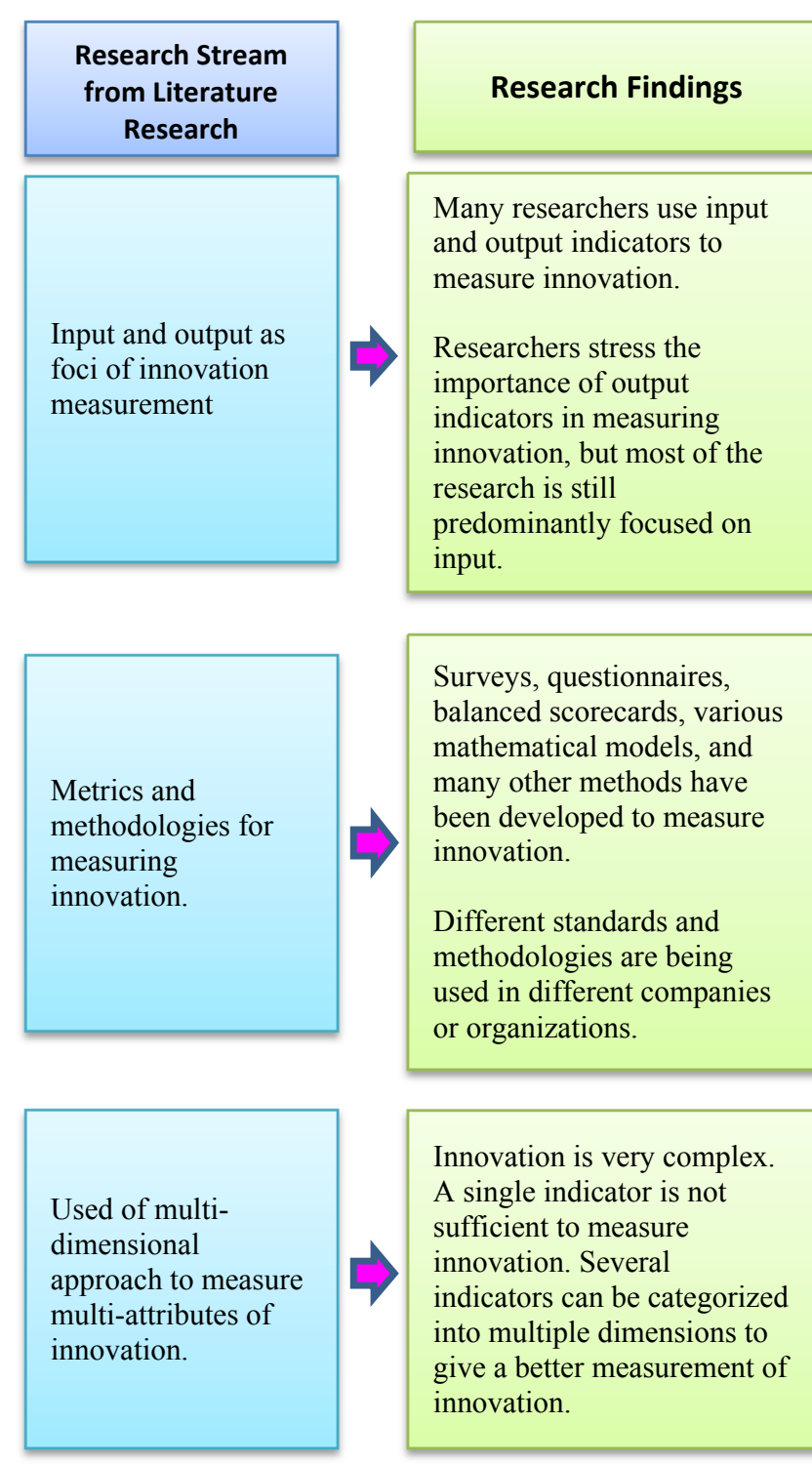

Surveys, questionnaires, balanced scorecards, various mathematical models, and many other methods have been developed to measure innovation.

Different standards and methodologies are being used in different companies or organizations.

Innovation is very complex. A single indicator is not sufficient to measure innovation. Several indicators can be categorized into multiple dimensions to give a better measurement of innovation.

\section{Research Gaps}

Gap 1: Current innovation measurement metrics are not comparable or consistent.

Gap 2: No general conceptual framework to measure innovation in a reliable, qualitative and quantitative, systematic and effective way

Gap 3: The use of output indicators in existing research is very limited. There is a need for more output indicators

Gap 4: There is no comprehensive measurement framework that focuses on innovation outputs

Gap 5: There is a lack of research to explore the relationship between innovation inputs and innovation outputs (this gap is not addressed in this research)

Gap 6: Researchers who use multidimensional approach pay little attention to measuring the relative importance of attributes

Figure 7.1 Research Streams, Primary Findings, and Research Gaps Identified from Literature Research 
This research has addressed five of the gaps listed above: 1, 2, 3, 4 and 6. There are three major contributions generated from this research. The first three are the contributions to the gaps identified through the literature review, and the fourth contribution is the application of the methodology to a specific industry for the demonstration of the model.

TABLE 7.1 FIRST CONTRIBUTION OF THE RESEARCH

Gap 1: Need more output indicators

Gap 2: Need to develop a measurement framework based on output indicators

First Contribution: The measurement is based on output indicators.

In the existing literature, it was identified that the measurement has always focused on input indicators, sometimes combined with output indicators. However, measuring innovation by taking inputs into account bring bias into the results since inputs are controllable. Output demonstrates the results of innovation while input is just an enabler of innovation. The literature emphasizes the need for identifying more output indicators and a measurement framework that is based merely on output indicators.

This research identified output indicators in Table 2.2. The measurement framework (model) developed in this research is also based output indicators. Thus, research gaps 1 and 2 have been addressed.

TABLE 7.2 SECOND CONTRIBUTION OF THE RESEARCH 
Some research by practitioners measures innovativeness by taking several indicators into account. However, the research failed to identify that not all indicators have the same importance for assessing the innovativeness of a company. This research formulated output indicators into a HDM. The relative importance of the indicators was assessed by comparing two indicators at the same time. The pairwise comparison method was utilized to determine the relative importance of each indicator to the innovativeness of a company. Thus, research gap 3 has been addressed.

\section{TABLE 7.3 THIRD CONTRIBUTION OF THE RESEARCH}

Gap 4: Current measurement metrics are not comparable and not consistent

Gap 5: There is no general conceptual framework to measure innovativeness

Third Contribution: Develop a model, measurement processes and metrics to measure innovativeness based on output indicators.

Literature research has also identified numerous methodologies to measure innovativeness. However, it is very difficult for a company to measure and benchmark itself with others if everybody is using different methodologies. The literature has identified the need to have a general conceptual framework to measure innovativeness. This research, through several iterations of data collection, has developed a general conceptual model, measurement process and metrics to measure innovativeness based on output indicators. Thus, research gaps 4 and 5 have been addressed.

Figure 7.2 below illustrates the contribution of this research to the research gaps identified in the literature research. 


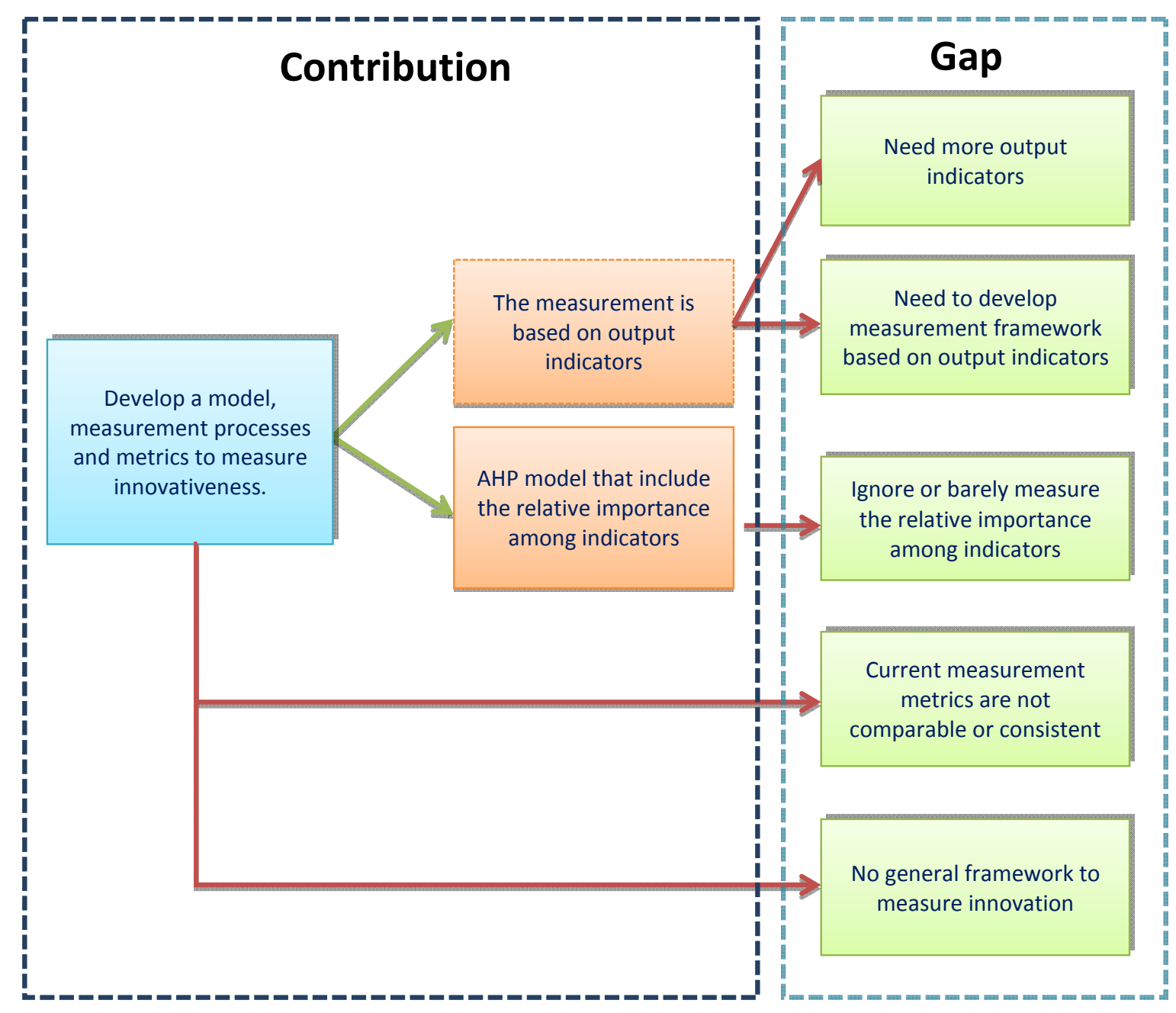

Figure 7.2 Contributions and Gaps of the Research

\subsection{ASSUMPTIONS}

Two major assumptions are made when selecting expert panels for judgment quantifications in the hierarchical decision models (HDMs).

1. All individuals in the expert panels are assumed to be knowledgeable and have the capability of providing their judgments in the innovation area.

2. Biases of the experts are balanced in the expert panel. 
These assumptions were addressed by carefully selecting the experts. Each expert selected for the expert panels had to meet the criteria listed in Chapter 4.9. This addressed the first assumption

Experts came from academia, industry, and government agencies. If they were from industry, they came from different areas of specialization and business units. Having different opinions from experts with different backgrounds balanced the biases. This addressed the second assumption.

The following assumptions are inherent in the HDM:

1. It is assumed that all output indicators and sub-factors have a hierarchical relationship among all levels.

2. It is assumed that the output indicators and sub-factors are independent among one another and they are preferentially independent.

The model was developed and validated with the appropriate elements at each level to assure hierarchical relationship. This addressed the first assumption.

The model was tested for preferential independent before quantified judgments were obtained from the experts. This addressed the second assumption.

\subsection{LIMITATIONS}

This research develops a measurement framework to help a company in the semiconductor industry assess its innovativeness. There are limitations associated with this research, however: 
- The measurements are focused on the output indicators without directly involving the input indicators. Further study is recommended to analyze the relationship between input and output indicators for identifying potential causalities.

- The outputs of this research rely on the subjective judgments of the experts. Limited knowledge and biases might affect the validity of the model. However, carefully selected experts minimized the biases.

- $\quad$ The research case study is limited to product innovation in technology-driven industries. However, the model can be expanded to other types of innovations in other industries.

- The relative priorities of output indicators and sub-factors are industry dependent. It may or may not be the same for other industries. However, the structure and the output indicators from this research provide a foundation for other industries to measure their innovativeness, as well.

- The relative priorities of output indicators and sub-factors are time dependent. Output indicators and sub-factors that are perceived as being the most important indicators might change in the future. However, the structure will not change drastically. The relative importance can be re-evaluated by collecting new judgment quantifications from different experts. 


\subsection{FUTURE RESEARCH}

This research provides opportunities for other researchers to continue and advance the state of the art of innovation by contributing to the body of knowledge in the area of innovation measurement. Several possible future studies are listed below:

a) This research focuses on product innovation in the high technology industry. Future research can be conducted to extend it to other types of industries such as pharmaceutical and automotive, which have very different environments and behaviors compared to the high technology industry. The measurement can also be extended to other areas of innovation such as process innovation, service innovation, and marketing innovation. These will be challenging research areas since there is very little research on how to measure service innovation and other types of innovation. However, the current study will provide the foundation to build on and to expand into the areas listed above.

b) The current research has developed a model that is able to calculate the innovativeness of a company as a numerical value. By knowing the numerical value, the company can improve its innovativeness by focusing on specific output indicators that need improvement. Future research should provide an in-depth understanding on how to boost output indicators. The research can focus on the relationship between output indicators and input indicators. It can uncover which input indicators will influence a particular output indicator. Regression analysis, simulation or other statistical analyses can be performed to find the correlation among the indicators. By confirming the correlation (if one exists), companies 
will know which particular input indicators they should pay attention to in order to increase a particular output indicator that has the correlation.

c) Future research can also be extended beyond the relationship of input and output indicators. Other factors such as corporate culture and manufacturing processes should be investigated in relation to input and output indicators. Multiple relations among all of those factors will give a more comprehensive picture on how to improve the innovativeness of a company.

d) Another extension of the current study can be an analysis of the relationship between the innovativeness index of a company and its operational efficiency. This extension will provide information about whether or not innovativeness results in efficiencies in companies. 


\section{REFERENCES}

[1] J. N. Bhagwati, Free Trade Today. Princeton University Press, 2003.

[2] T. Pugel, International Economics (Mcgraw-Hill Series Economics), 14 edition. McGrawHill/Irwin, 2008, p. 784.

[3] "AFTA \& FTAs," http://www.aseansec.org/4920.htm. [Online]. Available: http://www.aseansec.org/4920.htm. [Accessed: 16-Apr-2011].

[4] "Central European Free Trade Agreement - CEFTA 2006 | Cefta," http://www.cefta2006.com/. [Online]. Available: http://www.cefta2006.com/. [Accessed: 16-Apr-2011].

[5] "NAFTA," http://www.nafta-sec-alena.org/. [Online]. Available: http://www.nafta-sec-alena.org/. [Accessed: 16-Apr-2011].

[6]

"Free trade," http://www.oxfam.org.uk/education/resources/milking_it/milkingit/information/the_issues/free_trad e.htm. [Online]. Available: http://www.oxfam.org.uk/education/resources/milking_it/milkingit/information/the_issues/free_tra de.htm. [Accessed: 16-Apr-2011].

[7] Wikipedia, "Dot-com bubble," http://en.wikipedia.org/wiki/Dot-com_bubble. [Online]. Available: http://en.wikipedia.org/wiki/Dot-com_bubble.

[8] B. Abramson, "Digital Phoenix: Why the Information Economy Collapsed and How It Will Rise Again," Oct. 2006.

[9] S. Silverthorne, "The Rise of Innovation in Asia - HBS Working Knowledge," HBS Working Knowledge, F. Warren McFarlan, 07-Mar-2005.

[10] F. Bureau, "Boeing Opens Advanced R\&D Centre in Bangalore," The Indian Express, 2009. [Online]. Available: http://www.financialexpress.com/news/boeing-opens-advanced-r\&d-centre-inbangalore/441477/. [Accessed: 16-Apr-2011].

[11] A. D. Little, "Defying Downturn through Innovation," 2009.

[12] K. Wall, "Successful Approach for Improving Innovation Management for SME's," InnovationManagement, $2010 . \quad$ [Online]. Available: http://www.innovationmanagement.se/2010/03/22/successful-approach-for-improving-innovationmanagement-for-smes/.

[13] R. Charan and A. G. Lafley, "Why Innovation Matters," Fast Company, 2008. [Online]. Available: http://www.fastcompany.com/articles/2008/05/why-innovation-matters.html. [Accessed: 23-Apr$2011]$.

[14] The Advisory Committee on Measuring Innovation in the 21st Century Economy, "Innovation Measurement - Tracking the State of Innovation in the American Economy," 2008. 
[15] S. Hamm and W. C. Symonds, "Mistakes Made On The Road To Innovation," Bloomberg BusinessWeek, 2006.2 [Online]. Available: http://www.businessweek.com/magazine/content/06_48/b4011421.htm. [Accessed: 23-Apr-2011].

[16] F. Betz, Managing technological innovation: competitive advantage from change. John Wiley \& Sons, Inc., 1998, pp. 313-332.

[17] A. R. Thomas and T. J. Wilkinson, "The Distribution Trap: Keeping Your Innovations from Becoming Commodities | salesandmarketing.com," Sales \& Marketing management's, 2011. [Online]. Available: http://www.salesandmarketing.com/article/distribution-trap-keeping-yourinnovations-becoming-commodities. [Accessed: 26-Apr-2011].

[18] L. Morris, “Innovation Metrics: The Innovation Process and How to Measure It.” p. 20, 2008.

[19] H. Chesbrough, Open Innovation: The New Imperative for Creating and Profiting from Technology. Boston Mass.: Harvard Business School Press, 2003.

[20] C. Helfat, "Open Innovation: The New Imperative for Creating and Profiting from Technology," PERSPECTIVES- ACADEMY OF MANAGEMENT, vol. 20, no. 2, pp. 86 - 87, 2006.

[21] S. Lee, G. Park, B. Yoon, and P. J., "Open Innovation in SMEs - An Intermediated Network Model," Research Policy, vol. 39, no. 2, pp. 290 - 300, 2010.

[22] J. Christensen, M. H. Olesen, and J. S. Kjaer, "The Industrial Dynamics of Open Innovation Evidence from the Transformation of Consumer Electronics," RESEARCH POLICY, vol. 34, no. 10, pp. $1533-1549,2005$.

[23] X. Fan and J. Hu, "Regional Innovation Network and Enterprise Innovation Performance," in 2010 International Conference on Networking and Digital Society, 2010, pp. 233-236.

[24] L. Bai, J. Zhang, T. Zhou, and H. Li, "Data Envelopment Analysis evaluation of Informal Innovation Network," in 2010 International Conference on Mechanic Automation and Control Engineering, 2010, pp. 876-880.

[25] D. Hong and J. Zhanjing, "A Study on the Motivation of Cooperative R\&D between Private S\&T Enterprises and State Military Enterprises - From the Standpoint of Informal Innovation Network," in 2009 Fourth International Conference on Cooperation and Promotion of Information Resources in Science and Technology, 2009, pp. 168-172.

[26] H. Y. Shan and W. P. Wang, "The Effects of Some Knowledge Characteristics on the Evolution of Innovation Network," in IJCAI International Joint Conference on Artificial Intelligence, 2009, pp. $229-232$.

[27] E. Rogers, Diffusion of Innovations, 3rd ed. New York;London: Free Press ;;Collier Macmillan, 1983.

[28] T. Greenhalgh, G. Robert, F. MacFarlane, P. Bate, and O. Kyriakidou, "Diffusion of Innovations in Service Organizations: Systematic Review and Recommendations," The Milbank Quarterly, vol. 82, no. 4, pp. 581-629, 2004. 
[29] P. Byosiere, J. Luethge, A. Vas, and M. P. Salmador Sanchez, "Diffusion of Organizational Innovation : Knowledge Transfer through Social Networks," International Journal of Technology Management, 2007.

[30] J. Walker, "The Diffusion of Innovations among the American States," The American Political Science Review, vol. 63, no. 3, pp. 880-899, 1969.

[31] H.-C. Meng, "Innovation Cluster as the National Competitiveness Tool in the Innovation Driven Economy," International Journal of Foresight and Innovation Policy, vol. 2, no. 1, pp. $104-116$, 2005.

[32] D. Arthurs, E. Cassidy, C. H. Davis, and D. A. Wolfe, "Indicators to Support Innovation Cluster Policy," International Journal of Technology Management, vol. 46, no. 3/4, p. 263, 2009.

[33] D. S. Yim, "Management issue of government initiated innovation cluster: Case of Gwanggyo Techno-Valley," in PICMET '09 - Portland International Conference on Management of Engineering \& TechnologyPortland International Conference on Management of Engineering \& Technology, 2009, pp. 857-877.

[34] C. Haihua and C. Song, "Study on Motivations, Institutional Form and Organizations of Innovation Cluster," in 2009 International Conference on Information Management, Innovation Management and Industrial Engineering, 2009, pp. 436-439.

[35] J. Tyson, “User-Centered Innovation," Telesis, no. 100, 1995.

[36] P. Chayutsahakij and S. Poggenpohl, "User-Centered Innovation: The Interplay between UserResearch and Design Innovation," in The European Academy of Management 2nd Annual Conference on Innovative Research in Management, 2002.

[37] E. von Hippel, "Democratizing Innovation: The Evolving Phenomenon of User Innovation," Journal für Betriebswirtschaft, vol. 55, no. 1, pp. 63-78, Mar. 2005.

[38] J. Z. Shyu, C.-H. Yang, and C.-J. Chen, "Innovation intermediary for creating regional knowledge capabilities in knowledge cluster," in 2008 IEEE International Conference on Industrial Engineering and Engineering Management, 2008, pp. 831-835.

[39] J. Howells, "Intermediation and the Role of Intermediaries in Innovation," Research Policy, vol. 35, no. 5, pp. 715-728, Jun. 2006.

[40] D. Blondel, "Efficiency Criteria for Intermediaries Involved in the Innovation Process," International Journal of Technology Management, vol. 10, no. 4/5, pp. 478-488, 1995.

[41] I. Pallister, "Innovation Update 08-10: Measuring Innovation,” 2010.

[42] H. Rejeb, L. Morelguimaraes, V. Boly, and N. Assielou, "Measuring Innovation Best Practices: Improvement of an Innovation Index Integrating Threshold and Synergy Effects," Technovation, vol. 28 , no. 12, pp. 838-854, Dec. 2008. 
[43] P. Gupta, "Firm Specific Measures of Innovation," Chicago, 2007.

[44] M. Albayrakoglu, "Justification of New Manufacturing Technology: A Strategic Approach Using the Analytical Hierarchy Process," Production and Inventory Management Journal, vol. 37, no. 1, pp. 71-77, 1996.

[45] C. Carlsson and P. Walden, "AHP in Political Group Decisions: A Study in the Art of Possibilities," Interfaces, vol. 25, no. 4, pp. 14-29, 1995.

[46] C.-C. Liu, L.-M. Chuang, C.-M. Huang, and W.-C. Tsai, "Construction of Index Weight for Organizational Innovation in Taiwanese High-tech Enterprises," Journal of Business, vol. 4, no. May, pp. 594-598, 2010.

[47] P. R. Drake, "Using the Analytic Hierarchy Process in Engineering Education," International Journal of Engineering Education, vol. 14, no. 3, p. 191-196, 1998.

[48] T. L. Saaty, "Decision Making with the Analytic Hierarchy Process," International Journal of Services Sciences, vol. 1, no. 1, p. 83, 2008.

[49] S. Kavadias and R. O. Chao, "Resource Allocation and New Product Development Portfolio Management," in Handbook of New Product Development Research, Oxford: Elsevier/Butterworth, 2007.

[50] N. O'Regan, A. Ghobadian, and M. A. Sims, "Fast Tracking Innovation in Manufacturing SMEs," Technovation, vol. 26, no. 2, pp. 251-261, 2006.

[51] G. J. McGovern, D. Court, J. A. Quelch, and B. Crawford, "Bringing customers into the boardroom.," Harvard Business Review, vol. 82, no. 11, pp. 70-80, 148, 2004.

[52] J. K. Han, N. Kim, and R. K. Srivastava, "Market Orientation and Organizational Performance: Is Innovation a Missing Link?," Journal of Marketing, vol. 62, no. 4, p. 30, 1998.

[53] R. Escalfoni, V. Braganholo, and M. R. S. Borges, "Applying Group Storytelling to Capture Innovation Features," 2009 13th International Conference on Computer Supported Cooperative Work in Design, pp. 209-214, Apr. 2009.

[54] OECD, OSLO Manual. 1997.

[55] J. A. Schumpeter and R. Opie, The Theory of Economic Development: An Inquiry into Profits, Capital, Credit, Interest, and the Business Cycle. New Brunswick, N.J: Transaction Books, 1983, p. 255.

[56] OECD, "Oslo Manual, Guidelines for Collecting and Interpreting Innovation Data, 3rd Edition." 2005 .

[57] E. Commission, "Innobarometer," 2004.

[58] Innovation Vital Signs Project, "Defining 'Innovation': A New Framework to Aid Policymakers," Washington, DC: ASTRA, 2007. 
[59] C. O. Competitiveness, "Innovate America: National Innovation Initiative Summit and Report," 2005.

[60] L. Potters, "Innovation Input and Output : Differences among Sectors," Communities, no. 10. p. 38, 2009.

[61] A. Sood and G. J. Tellis, "Innovation Does Pay Off - If You Measure Correctly," Research • Technology Management, no. August, pp. 13-16, 2009.

[62] H. Hollanders and F. C. Esser, "Measuring Innovation Efficiency. INNO-Metrics Thematic Paper," 2007.

[63] G. Dosi, "The Nature of the Innovative Process," in Technical Change and Economic Theory, G. Dosi, C. Freeman, R. R. Nelson, G. Silverberg, and L. Soete, Eds. Pinter Publishers, 1988, pp. 221238.

[64] J. Tidd, J. Bessant, and K. Pavitt, Managing Innovation (2nd edition). John Wiley and Sons, 2001.

[65] E. Milbergs and N. Vonortas, "Innovation Metrics : Measurement to Insight,” 2006.

[66] C. Bloch, "Innovation Measurement: Present and Future Challenges," Communities. p. 15, 2005.

[67] B. Kingsland, "Proposal for New Innovation Measurement." p. 22, 2007.

[68] R. Cordero, "The Measurement of Innovation Performance in the Firm: An Overview," Research Policy, vol. 19, no. 2, pp. 185-192, 1990.

[69] M. Reffitt, C. Sorenson, N. Blodgett, R. Waclawek, and B. Weaver, "Innovation Indicators: Report to the Council for Labor and Economic Growth,” 2007.

[70] A. Arundel and H. Hollanders, "Searching the Forest for the Trees: 'Missing' Indicators of Innovation," 2006.

[71] J. Vega-Jurado, A. Gutierrez-Gracia, I. Fernandez-de-Lucio, and L. Manjarres-Henriquez, "The Effect of External and Internal Factors on Firms' Product Innovation," Research Policy, vol. 37, no. 4, pp. 616-632, May 2008.

[72] R. Griffith, E. Huergo, J. Mairesse, and B. Peters, "Innovation and Productivity across Four European Countries," Oxford Review of Economic Policy, vol. 22, no. 4, pp. 483-498, 2006.

[73] B. Godin, "Measuring Output: When Economics Drive Science and Technology Measurements," Montreal: OST, 2001.

[74] B. Gold, "The Impact of Technological Innovation--Concepts and Measurement," Omega, vol. 1, no. 2, pp. 181-191, 1973.

[75] B. Basberg, "Patents and the Measurement of Technological Change: A Survey of the Literature," Research Policy, vol. 16, no. 2-4, pp. 131-141, Aug. 1987. 
[76] McKinsey Global, "McKinsey Global Survey Results: Assessing Innovation Metrics," McKinsey Quarterly, 2008.

[77] D. Archibugi and G. Sirilli, "The Direct Measurement of Technological Innovation in Business," Innovation and Enterprise Creation: Statistics and Indicators, European Commission (Eurostat), ed. Luxembourg: European Commission, 2001.

[78] S. Rose, S. Shipp, B. Lal, and A. Stone, "Frameworks for Measuring Innovation: Initial Approaches." p. 24, 2009.

[79] B. Moos, D. Beimborn, and T. Weitzel, "Suggestions For Measuring Organizational Innovativeness : A Review," Measurement, pp. 1-10, 2010.

[80] X. Wei and F. Xiaobin, "Research on the Relationship between Organizational Learning, Product Innovativeness and Product Quality," 2009 International Conference on Information Management, Innovation Management and Industrial Engineering, no. 2001, pp. 466-470, Dec. 2009.

[81] R. Evangelista, S. Iammarino, V. Mastrostefano, and A. Silvani, "Measuring the Regional Dimension of Innovation. Lessons from the Italian Innovation Survey," Technovation, vol. 21, no. 11, pp. 733-745, Nov. 2001.

[82] P. H. Jensen and E. Webster, "Examining Biases in Measures of Firm Innovation,” 2004.

[83] Q. R. Xu, L. Zhu, and G. Zhen, "The Measurement of Total Innovation Capacity Case Study of Several Chinese Firms," in 2004 IEEE International Engineering Management Conference, 2004, pp. $622-625$.

[84] A. M. Aizcorbe, C. E. Moylan, and C. A. Robbins, "Toward Better Measurement of Innovation and Intangibles," Survey of Current Business, pp. 10-23, 2009.

[85] G. Choi and S.-S. Ko, "An Integrated Metric for R \& D Innovation Measurement," Integration The Vlsi Journal, 2010.

[86] C. Liu, "A Study on the Evaluation Index and Weight for Organizational Innovation," Journal of Applied Sciences, vol. 4, no. 3, pp. 444-448, Mar. 2004.

[87] L. Chuang, "An Empirical Study of the Construction of Measuring Model for Organizational Innovation in Taiwanese High-tech Enterprises," The Journal of American Academy of Business, vol. 6, no. 1, 2005.

[88] J. Guan and K. Chen, "Measuring the Innovation Production Process: A Cross-region Empirical Study of China's High-tech Innovations," Technovation, vol. 30, no. 5-6, pp. 348-358, May 2010.

[89] E. Y. Huang and S.-C. Lin, "How R\&D Management Practice Affects Innovation Performance: An Investigation of the High-tech Industry in Taiwan," Industrial Management \& Data Systems, vol. 106, no. 7, pp. 966-996, 2006.

[90] H.-A. Zheng, J.-J. Chanaron, J. You, and X. Chen, "Designing a Key Performance Indicator System for Technological Innovation Audit at Firm's Level: A Framework and an Empirical 
Study," in 2009 IEEE International Conference on Industrial Engineering and Engineering Management, 2009, no. 1996, pp. 1-5.

[91] R. Adams, J. Bessant, and R. Phelps, "Innovation Management Measurement: A Review," International Journal of Management Reviews, vol. 8, no. 1, pp. 21-47, Mar. 2006.

[92] M. A. Heras and H. Dröge, "Exploring Innovation Measurement Approaches in the Service Sector: Insights from the Hospitality Industry," 2009.

[93] E. G. Carayannis, "Past, Present, and Emerging Innovation Metrics and Indicators. Public and Private Sector Prespectives," 2007.

[94] J. O. Lanjouw and M. Schankerman, "The Quality of Ideas: Measuring Innovation with Multiple Indicators." p. 39, 1999.

[95] J. Hagedoorn and M. Cloodt, "Measuring Innovative Performance: Is there an Advantage in Using Multiple Indicators?," Research Policy, vol. 32, no. 8, pp. 1365-1379, Sep. 2003.

[96] C. Hipp and H. Grupp, "Innovation in the Service Sector: The Demand for Service-Specific Innovation Measurement Concepts and Typologies," Research Policy, vol. 34, pp. 517-535, Apr. 2005.

[97] K. Blomqvist, E. Harkink, K. Drongelen, and V. Ojanen, "Measuring Innovativeness - Challenges and Possibilities for Knowledge-Based Firms," Industrial Engineering, 2004.

[98] R. McAdam and W. Keogh, "Transitioning Towards Creativity and Innovation Measurement in SMEs," Creativity and Innovation Management, vol. 13, no. 2, pp. 126-139, Jun. 2004.

[99] D. Wang and K. Dickson, "Measuring Technological Innovation of Small and Medium-sized Manufacturing Enterprises in China," in 2000 IEEE International Conference on Management of Innovation and Technology, 2000, pp. 479-484.

[100] E. Hansen, H. Juslin, and C. Knowles, "Innovativeness in the global forest products industry: exploring new insights," Canadian Journal of Forest Research, vol. 37, no. 8, pp. 1324-1335, 2007.

[101] L. Crosta and V. Prieto, "How to Measure Innovation in eLearning: The i-AFIEL Methodology." p. $12,2009$.

[102] M. Subramaniam and M. A. Youndt, "The Influence of Intellectual Capital on the Types of Innovative Capabilities," Academy of Management Journal, vol. 48, no. 3, pp. 450-463, 2005.

[103] National Research Council, Industrial Research and Innovation Indicator: Report of a Workshop. National Academies Press, 1997, p. 62.

[104] P. H. Jensen and E. Webster, "Another Look at the Relationship Between Innovation Proxies," Australian Economic Papers, vol. 48, no. 3, pp. 252-269, Sep. 2009.

[105] J. Mairesse and P. A. Mohnen, "The Importance of R\&D for Innovation: A Reassessment Using French Survey Data," Journal of Technology Transfer, vol. 30, no. 1-2, pp. 183-197, 2004. 
[106] P. A. M. Vermeulen, K. C. O'Shaughnessy, and J. P. J. De Jong, "Innovation in SMEs : An Empirical Investigation of the Input-Througput-Output-Performance Model,” 2003.

[107] F. I. Ortiz, E. E. Brito, and M. L. Ovalles, "System Approach for Measuring Innovation Technology Capacity in Developing Countries," in PICMET '07 - 2007 Portland International Conference on Management of Engineering \& TechnologyPortland International Conference on Management of Engineering \& Technology, 2007, pp. 611-616.

[108] H. Lööf and A. Hesmati, "Knowledge Capital and Performance Heterogeneity: A Firm-level Innovation Study," International Journal of Production Economics, vol. 76, no. 1, pp. 61-85, 2002.

[109] J. R. Velasquez, J. J. A. Zambrano, and J. D. P. Velez, "Methodological Tool for Measurement and Assessment of Technological Innovation Capabilities," in Technology Management in the Energy Smart World (PICMET), 2011 Proceedings of PICMET '11:, 2011, pp. 1-8.

[110] B. Godin, "The Rise of Innovation Surveys: Measuring a Fuzzy Concept," no. 16. p. 26, 2002.

[111] R. Coombs, P. Narandren, and A. Richards, "A Literature-based Innovation Output Indicator," Research Policy, vol. 25, pp. 403-413, 1996.

[112] R. M. Walker, E. Jeanes, and R. Rowlands, "Measuring Innovation-Applying the Literature-based Innovation Output Indicator to Public Services," Public Administration, vol. 80, no. 1, p. 201, 2002.

[113] T. Clayton, M. D. Borgo, J. Haskel, and M. Franklin, "Measuring Creativity and Innovation Based on Knowledge Capital Investment," 2010.

[114] B. Glassman, "Metrics for Idea Generation.” p. 7, 2009.

[115] T. Maeno, N. Shibata, Y. Kajikawa, and I. Sakata, "Investigation of a lead indicator of technological innovations," in Technology Management in the Energy Smart World (PICMET), 2011 Proceedings of PICMET '11:, 2011, pp. 1-6.

[116] Y. Ken, N. Y. Pai, T. S. Hung, and C. H. Wu, "The measurement of innovation capability and competence of game software companies through patent indicators," in Technology Management in the Energy Smart World (PICMET), 2011 Proceedings of PICMET '11:, 2011, pp. 1-9.

[117] M.-T. Tsai, S. S. Chuang, and W. P. Hsieh, "Using Analytic Hierarchy Process to Evaluate Organizational Innovativeness in High-Tech Industry," in Decision Sciences Institute 2008 Annual Meeting (DSI), 2008.

[118] P. C. Verhoef and P. S. . Leeflang, "Understanding the Marketing Department's Influence Within the Firm," Journal of Marketing, vol. 73, no. 2, pp. 14-37, Mar. 2009.

[119] J. Mote, G. Jordan, and J. Hage, "Measuring Radical Innovation in Real Time," International Journal of Technology, Policy and Management, vol. 7, no. 4, pp. 355 - 377, 2007.

[120] M. L. Flor and M. J. Oltra, "Identification of Innovating Firms through Technological Innovation Indicators: An Application to the Spanish Ceramic Tile Industry," Research Policy, vol. 33, no. 2, pp. 323-336, Mar. 2004. 
[121] H. Romijn and M. Albaladejo, "Determinants of Innovation Capability in Small Electronics and Software Firms in Southeast England," Research Policy, vol. 31, no. 7, pp. 1053-1067, 2002.

[122] S. -h. Liao, W.-C. Fei, and C.-C. Chen, "Knowledge Sharing, Absorptive Capacity, and Innovation Capability: an Empirical Study of Taiwan's Knowledge-intensive Industries," Journal of Information Science, vol. 33, no. 3, pp. 340-359, Mar. 2007.

[123] G. G. Bell, "Clusters, Networks, and Firm Innovativeness," Strategic Management Journal, vol. 26, no. 3, pp. 287-295, Mar. 2005.

[124] H. Chen, C. Li, Y. Zhang, and C. Ao, "Application of Improved AHP in Evaluation of Technological Innovation Capability Progress of State-Owned Enterprises in the Northeast Industrial Base," in International Conference on Management and Service Science, 2009. MASS '09., 2009, pp. 1-4.

[125] L. Kai, W. Dan, and D. Chuangzheng, "Evaluation on Innovation Ability of Industrial Clusters," in Information Management, Innovation Management and Industrial Engineering, 2009, pp. 478-483.

[126] X. Chen, W. Liao, and S. Liu, "Research of Evaluation Indicators Supporting Innovation," in IEEE International Conference on Grey Systems and Intelligent Services, 2007. GSIS 2007., 2007, pp. $1261-1268$.

[127] K. Jain, Q. Siddiquee, and V. Singal, "Measurement of innovativeness in an organisation using AHP," in PICMET '10 - Portland International Center for Management of Engineering and Technology, Proceedings - Technology Management for Global Economic Growth, 2010, pp. 1097-1107.

[128] X. Ying, C. Chang-xing, G. Jingjing, and C. Yipeng, "Service Innovation Performance Evaluation in Service Enterprise - Based on Wuhan Telecom Best Tone Center," in Management and Service Science, 2009, pp. 1-6.

[129] D. Birchall and G. Tovstiga, "Innovation Performance Measurement: Expert vs. Practitioner Views," 2006 Technology Management for the Global Future - PICMET 2006 Conference, no. c, pp. 870-883, Jul. 2006.

[130] L. Klomp, “Measuring Output from R\&D Activities in Innovation Surveys,” 2001.

[131] F. Steward, Y. Wang, and J. Tsoi, "Direct Measurement of Innovation Output Using Documentary and Digital Sources," 2008.

[132] D. Ayers, R. Dahlstrom, and S. J. Skinner, "An Exploratory Investigation of Organizational Antecedents to New Product Success," Journal of Marketing Research, vol. 34, no. 1, p. 107, 1997.

[133] M. Geoghegan-Quinn, "Elements for the Setting-up of Headline Indicators for Innovation in Support of the Europe 2020 Strategy," 2010.

[134] E. Santarelli, “Analyzing Literature-based Innovation Output Indicators: The Italian Experience," Research Policy, vol. 25, no. 5, pp. 689-711, Aug. 1996. 
[135] A. Zaheer and G. G. Bell, "Benefiting from Network Position: firm Capabilities, Structural Holes, and Performance," Strategic Management Journal, vol. 26, no. 9, pp. 809-825, Sep. 2005.

[136] M. Woerter and S. Roper, "Openness and innovation-Home and Export Demand Effects on Manufacturing Innovation: Panel Data Evidence for Ireland and Switzerland," Research Policy, vol. 39, no. 1, pp. 155-164, Feb. 2010.

[137] F. T. Rothaermel and a. M. Hess, "Building Dynamic Capabilities: Innovation Driven by Individual-, Firm-, and Network-Level Effects," Organization Science, vol. 18, no. 6, pp. 898-921, Nov. 2007.

[138] C.-Y. Tseng and L.-Y. Wu, "Innovation Quality in the Automobile Industry: Measurement Indicators and Performance Implications," International Journal of Technology Management, vol. 37, no. 1/2, pp. 162-177, 2007.

[139] R. Henderson and I. Cockburn, "Measuring Competence? Exploring Firm Effects in Pharmaceutical Research," Strategic Management Journal, vol. 15, no. S1, pp. 63-84, 1994.

[140] Y. Tao, W. Zhang, and Z. Qi, "Measuring the Technology-push Effect of Technological Innovation," in IEEE International Conference on Grey Systems and Intelligent Services, 2007. GSIS 2007, 2007, pp. 1399-1403.

[141] D. Marinova, "Actualizing Innovation Effort: The Impact of Market Knowledge Diffusion in a Dynamic System of Competition," Journal of Marketing, vol. 68, no. 3, pp. 1-20, Jul. 2004.

[142] A. R. Shapiro, "Measuring Innovation: Beyond Revenue from New Products," Research • Technology Management, no. November, pp. 42-51, 2006.

[143] A. N. Link, "The Use of Literature-based Innovation Output Indicators for Research Evaluation," Small Business Economics, vol. 7, no. 6, pp. 451-455, Dec. 1995.

[144] Innovation Vital Signs Project, "Innovation Indicators for Tomorrow: Innovation Vital Signs Project 'Candidates' - by Framework Category," 2007.

[145] A. Ali, "Pioneering Versus Incremental Innovation: Review and Research Propositions," Journal of Product Innovation Management, vol. 11, no. 1, pp. 46-61, 1994.

[146] D. Leonard-Barton, E. Wilson, and J. Doyle, "Commercializing Technology: Imaginative Understanding of User Needs," Harvard Business School Technical Note, vol. N9-694-102, pp. 128, 1994.

[147] R. Balachandra and J. H. Friar, "Factors for Success in R\&D Projects and New Product," IEEE Transactions on Engineering Management, vol. 44, no. 3, p. 276, 1997.

[148] D. J. Kiewiet and M. C. Achterkamp, "Images of New Product Success: A Case Study in Search of Local Validity," European Journal of Innovation Management, vol. 11, no. 1, pp. 87-102, 2008.

[149] United State Patent And Trademark Office, "What Are Patents, Trademarks, Servicemarks, and Copyrights?," http://www.uspto.gov/web/offices/pac/doc/general/whatis.htm, 2004. [Online]. 
Available: http://www.uspto.gov/web/offices/pac/doc/general/whatis.htm. [Accessed: 06-Dec2010].

[150] A. Subramanian, "Innovativeness: Redefining the Concept," Journal of Engineering and Technology Management, vol. 13, no. 3-4, pp. 223-243, Sep. 1996.

[151] S. Salomo, K. Talke, and N. Strecker, "Innovation Field Orientation and Its Effect on Innovativeness and Firm Performance," Journal of Product Innovation Management, vol. 25, no. 6, pp. 560-576, Nov. 2008.

[152] S. G. Green, M. B. Gavin, and L. Aiman-Smith, "Assessing a Multidimensional Measure of Radical Technological Innovation," IEEE Transactions on Engineering Management, vol. 42, no. 3, pp. 203-214, 1995.

[153] A. Kleinknecht and D. Bain, "Why do we need new innovation output indicators?," in New Concepts in Innovation Output Measurement, A. Kleinknecht and D. Bain, Eds. New York, US: St. Martins Press, 1993, pp. 1-9.

[154] C. Guo Hong, X. Xi Feng, and L. Mei Uan, "Study on Identification for the Evaluation Indicator System of the Regional Technology Innovation Capability," in Wireless Communications, Networking and Mobile Computing, 2008. WiCOM '08, 2008, pp. 1-4.

[155] W. Tsai, "Knowledge Transfer in Intraorganizational Networks: Effects of Network Position and Absorptive Capacity on Business Unit Innovation and Performance," The Academy of Management Journal, vol. 44, no. 5, p. 996, Oct. 2001.

[156] P. Gerdsri, "A Systematic Approach to Developing n National Technology Policy and Strategy for Emerging Technologies," Portland State University, 2009.

[157] H. Chen and D. F. Kocaoglu, "A sensitivity analysis algorithm for hierarchical decision models," European Journal Of Operational Research, vol. 185, no. 1, pp. 266-288, 2008.

[158] T. L. Saaty, "A Scaling Method fo Priorities in Hierarchical Structures," Journal of Mathematical Psychology, vol. 15, no. 3, pp. 234-281, 1977.

[159] F. Zahedi, "The Analytic Hierarchy Process - A Survey of the Method and its Applications," Interfaces, vol. 16, no. 4, pp. 96-108, 1986.

[160] T. L. Saaty, The Analytic Hierarchy Process. McGraw-Hill, 1980, pp. 1-17.

[161] T. L. Saaty, Fundamentals of Decision Making and Priority Theory with the Analytic Hierarchy Process, vol. 6. RWS Publications, 2000.

[162] T. L. Saaty, "How to Make a Decision: The Analytic Hierarchy Process," European Journal Of Operational Research, vol. 48, no. 1, pp. 9-26, 1990.

[163] R. Kodali and S. Chandra, "Analytical Hierarchy Process for Justification of Total Productive Maintenance," Production Planning Control The Management of Operations, vol. 12, no. 7, pp. 695-705, 2001. 
[164] Y. Chan and B. Lynn, "Performance Evaluation and the Analytic Hierarchy Process," Journal of Management Accounting Research, vol. 3, pp. 57-87, 1991.

[165] C. Hepler and G. Mazur, "The Analytic Hierarchy Process - Methodologies and Application with Customers and Management at Blue Cross-blue Shield of Florida," in International Symposium on QFD 2007, 2007, pp. 137-149.

[166] J. Yang and P. Shi, "Applying Analytic Hierarchy Process in Firm's Overall Performance Evaluation : A Case Study in China," International Journal, vol. 7, no. 1, 2002.

[167] R. Ramanathan, "A Note on the Use of the Analytic Hierarchy Process for Environmental Impact Assessment.," Journal of Environmental Management, vol. 63, no. 1, pp. 27-35, 2001.

[168] Dundar Kocaoglu, "A participative approach to program evaluation," IEEE Transactions on Engineering Management, vol. EM-30, pp. 112-118, 1983.

[169] J. J. Bartko, "On various intraclass correlation reliability coefficients.," Psychological Bulletin, vol. 83, no. 5, pp. 762-765, 1976.

[170] P. E. Shrout and J. L. Fleiss, "Intraclass Correlations: Uses in Assessing Rater Reliability," Psychological Bulletin, vol. 86, no. 2, pp. 420-428, 1979.

[171] H. Chen, "Sensitivity Analysis for Hierarchical Decision Models," Portland State University, 2007.

[172] J. Jones and D. Hunter, "Using the Delphi and Nominal Group Technique in Health Services Research," in Qualitative Research in Health Care, 1999.

[173] J. P. Martino, Technological forecasting for decision making, vol. 3rd Editio. Mcgraw-Hill (Tx), 1993, p. 462.

[174] G. Rowe and G. Wright, "The Delphi Technique as a Forecasting Tool: Issues and Analysis," International Journal of Forecasting, vol. 15, no. 4, pp. 353-375, 99AD.

[175] J. Dajani, "Stability and agreement criteria for the termination of Delphi studies," Technological Forecasting and Social Change, vol. 13, no. 1, pp. 83-90, 1979.

[176] V. G. Voinov, "Chi-square goodness-of-fit test for one- and multidimensional discrete distributions," Journal of Mathematical Sciences, vol. 4, no. 8, pp. 753-450, 1994.

[177] N. Dalkey and O. Helmer, "An Experimental Application of the DELPHI Method to the Use of Experts," Management Science, vol. 9, no. 3, pp. 458-467, 1963.

[178] J. F. Preble, "The selection of Delphi panels for strategic planning purposes," Strategic Management Journal, vol. 5, no. 2, pp. 157-170, 1984.

[179] J. Martino, "An Experiment with the Delphi Procedure for Long-Range Forecasting," IEEE Transcriptions on Engineering Munugement, pp. 138-144, Feb. 1968.

[180] H. L. Dreyfus and S. E. Dreyfus, "Peripheral Vision: Expertise in Real World Contexts," Organization Studies, vol. 26, no. 5, pp. 779-792, 2005. 
[181] K. A. Ericsson, M. J. Prietula, and E. T. Cokely, "The Making of an Expert The Making of an Expert," Most, 2007.

[182] R. G. Cooper and S. J. Edgett, Successful Product Innovation: A Collection of Our Best. BookSurge Publishing, 2009.

[183] D. L. Rainey, Product innovation: leading change through integrated product development. Cambridge University Press, 2005, p. 625.

[184] G. Steinhardt, "Who's driving your company?," The Marketing Journal for High-Tech Product Managers, vol. 2, no. 2, 2004.

[185] S. Berman and J. Hagan, "How technology-driven business strategy can spur innovation and growth," IEEE Engineering Management Review, vol. 34, no. 3, pp. 31-31, Jul. 2006.

[186] W. Ballhaus, A. Pagella, and C. Vogel, "A change of pace for the semiconductor industry?,” 2009.

[187] SKC Inc., "Industry Guide: Semiconductor Industry."

[188] H. S. Bennett, "Semiconductor Industry Be Met?," Journal of Research of the National Institute of Standards and Technology, vol. 112, no. 1, pp. 25-38, 2007.

[189] European Semiconductor Industry Association, "Europe's semiconductor industry ranks second in EU R\&D intensity scoreboard even in turbulent times, as EU sets itself to discuss how to boost innovation and key enabling technologies," Brussels, 2010.

[190] H. S. Bennett, "Semiconductor Industry Be Met?," Journal of Research of the National Institute of Standards and Technology, vol. 112, no. 1, pp. 25-38, 2007.

[191] H. Gruber, "EUROPEAN INVESTMENTBANK The Semiconductor Industry: Review of the Sector and Financing Opportunities."

[192] C. Møldrup, J. M. Morgall, and A. B. Almarsdóttir, "Perceived risk of future drugs—a Danish citizen Delphi," Health Risk Society, vol. 4, no. 1, pp. 5-17, 2002.

[193] O. Kuusi, Exoertise in the future use of generic technologies - epistemic and methodological considerations concerning delphi studies. Valtion taloudellinen tutkimuskeskus, 1999, p. 284.

[194] L. Susskind, S. McKearnan, and J. Thomas-Larmer, The Consensus Building handbook: A Comprehensive Guide to Reaching Agreement. Sage Publications, 1999, pp. xxiv, 1147.

[195] R. Valerdi, "Convergence of Expert Opinion via the Wideband Delphi Method: An Application in Cost Estimation Models," Journal of Technological Forecasting and Social Change.

[196] J. Mohammadi, "Evaluation of system reliability using expert opinions," Structural Safety, vol. 9, no. 3, pp. 227-241, Feb. 1991.

[197] “TechPowerUp.” [Online]. Available: http://www.techpowerup.com/. [Accessed: 20-Mar-2013]. 
[198] “AMD vs Intel.” [Online]. Available: http://www.diffen.com/difference/AMD_vs_Intel. [Accessed: 20-Mar-2013].

[199] M. Ølholm, "Intel: Chinese microprocessor development inefficient," 2011. [Online]. Available: http://semiaccurate.com/2011/06/13/intel-chinese-microprocessor-developmentinefficient/\#.UVsio5NqnH1. [Accessed: 20-Mar-2013].

[200] "Intel Corporation Website." [Online]. Available: http://www.intel.com/. [Accessed: 20-Mar2013].

[201] “AMD Website.” [Online]. Available: http://www.amd.com/ . [Accessed: 20-Mar-2013].

[202] "United States Patent and Trademark Office." [Online]. Available: http://patft.uspto.gov/. [Accessed: 20-Mar-2013].

[203] “Trefis.”[Online]. Available: http://www.trefis.com/. [Accessed: 20-Mar-2013].

[204] “Engineering Village.” [Online]. Available: http://www.engineeringvillage.com/. [Accessed: 20Mar-2013].

[205] "PassMark Software." [Online]. Available: http://www.cpubenchmark.net/market_share.html. [Accessed: 20-Mar-2013]. 
APPENDIX A: RESEARCH INSTRUMENT 
Appendix A-1: Research Instrument 1

\section{Invitation to be an Expert in my PhD Research}

Dear Dr. X,

I am a PhD student in the Department of Engineering and Technology Management, at Portland State University, conducting research in Technology Management. The topic of my $\mathrm{PhD}$ research is Innovation Measurement - A Decision Framework to Determine Innovativeness of a Company.

I will develop a framework, measurement processes and metrics for measuring innovativeness in technology-driven industries.

As part of my research, I will have three Expert Panels to help me construct a decision model to determine the innovativeness of a company based on innovative outputs. In addition, the expert panels will also provide judgment quantifications on the relative importance of the indicators.

I have identified you as an expert in the field. Your background and expertise will be very helpful in my research. If you agree to be on the Expert Panels, I will send you webbased survey instruments to ask for your opinion. Each survey will take around 5-10 minutes to complete. There will be total of 3-5 web-based surveys.

I will be honored if you accept my invitation and join my expert panels, and will appreciate it greatly if you also suggest other experts on innovativeness in technologydriven industries as potential Expert Panel members.

Please fill out the form below and return it to me at your earliest convenience. I look forward to receiving your reply.

\section{Your Name:}

[ ] I will join your Expert Panels

[ ] I will not be able to join your expert panels

[ ] I suggest the following colleagues as potential inclusions in the Expert Panels

Name: E-Mail:

Name: E-Mail: 
Appendix A-2: Research Instrument 2

\section{CONSENT FORM - Innovation Measurement - A Decision Framework to Determine Innovativeness of a Company}

You are invited to participate in a research study conducted by Kenny Phan from Portland State University, Engineering and Technology Management Department. The researcher hopes to learn the output indicators that indicate the innovativeness of a company. This project is being conducted in partial fulfillment for the requirements of a PhD's degree under supervision by Dr. Dundar F. Kocaoglu. You were selected as a possible participant because you have experience in innovation related project or company that the researcher is examining for the study.

If you decide to participate, you will be asked to provide information about your experiences in managing innovation. You may not receive any direct benefit from taking part in this study, but the study may help to increase knowledge that may help others in the future.

Your name and responses will be confidential. Your participation is voluntary. You do not have to take part in this study and it will not affect anything in your career or life. You may also withdraw from this study at any time without affecting your career or life.

If you have concerns or problems about your participation in this study or your rights as a research subject, please contact the Human Subjects Research Review committee, Office of Research Strategic Partnerships, 1600 SW Fourth Avenue, Suite 620, Portland, OR, 97201, (503) 7253423 . If you have any questions about the study itself, contact Kenny at 1705 SW $11^{\text {th }}$ Ave \#532, Portland, OR, 97201, (503) 8048855.

Your signature indicates that you have read and understand the above information and agree to take part in this study. Please understand that you may withdraw your consent at any time without penalty, and that by signing, you are not waiving any legal claims, rights or remedies. The researcher will provide you with a copy of this form for your records.

Signature:

Date: 
Appendix A-3: Research Instrument 3

\section{Innovation Measurement - Web Based Survey First Round}

Dear Dr. X,

Thank you for accepting my invitation to be on the Expert Panels for my $\mathrm{PhD}$ research.

As the first step of the study, I am asking you to help me finalize the output indicators that contribute to the innovativeness of a company in semiconductor industry. The preliminary output indicators that have been identified in literature review are listed on the survey instrument that I am sending to you now.

Please click the following link for the survey instrument.

http://research1.etm.pdx.edu/kenny/

You will see the instructions on submitting your response after you click the link.

I will appreciate if you please fill out the survey instrument at your earliest convenience 


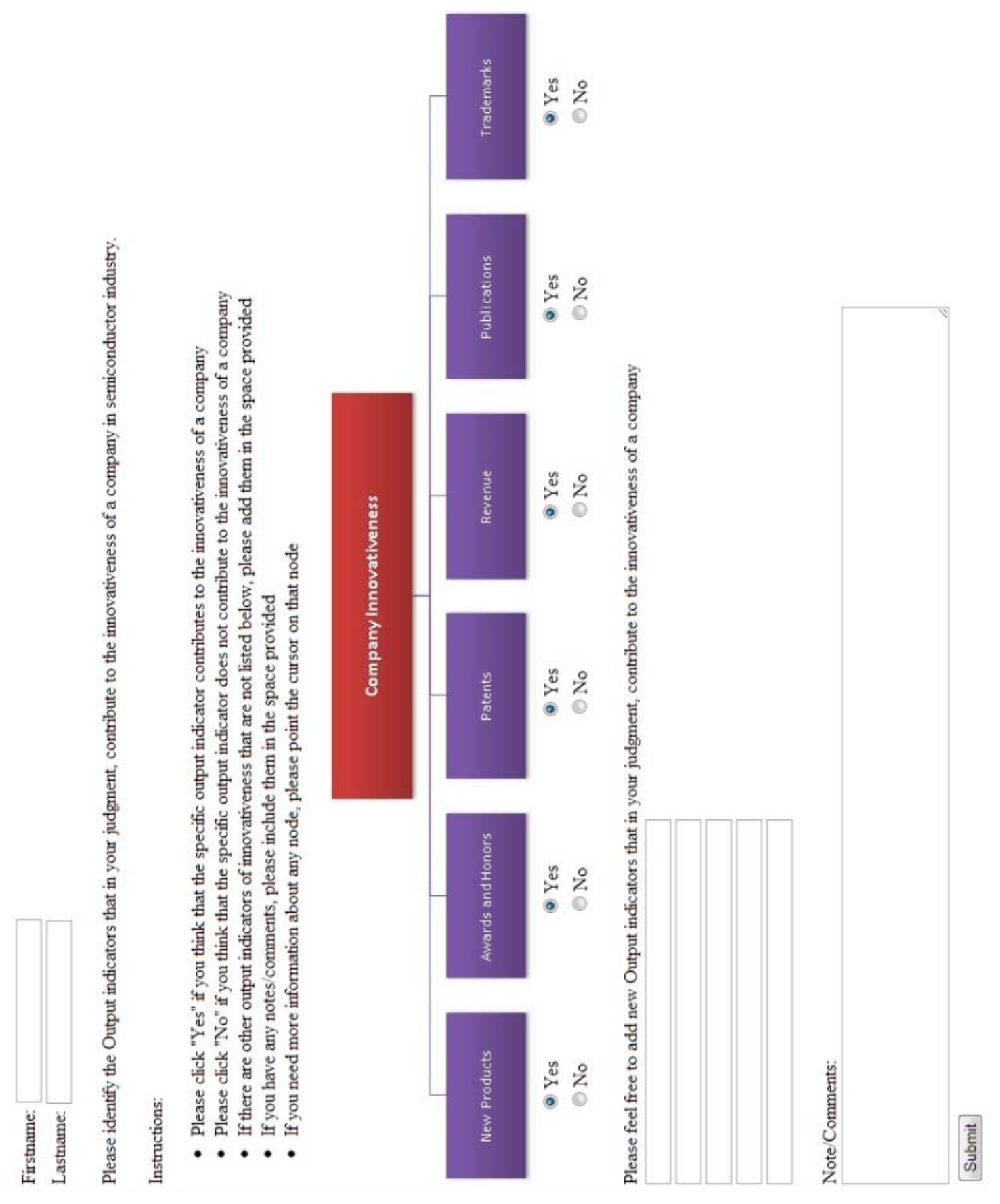


Appendix A-4: Research Instrument 4

\section{Innovation Measurement - Web Based Survey Second Round}

Dear Dr. X,

A couple of weeks ago, I sent the first round of web-based survey instrument to you. I received great responses from my expert panels. So far, we have at least $2 / 3$ of the experts agreeing on each output indicator. There is one addition of output indicator suggested by several experts.

Please click on the following link and give me your response on the additional output indicator. http://research1.etm.pdx.edu/kenny/Phase2.aspx

It will not take more than 5 minutes of your time.

After I hear from you, the top level of the output indicators will be finalized and we can move to the sub-factors for each indicator.

Thank you for your time and valuable inputs. 


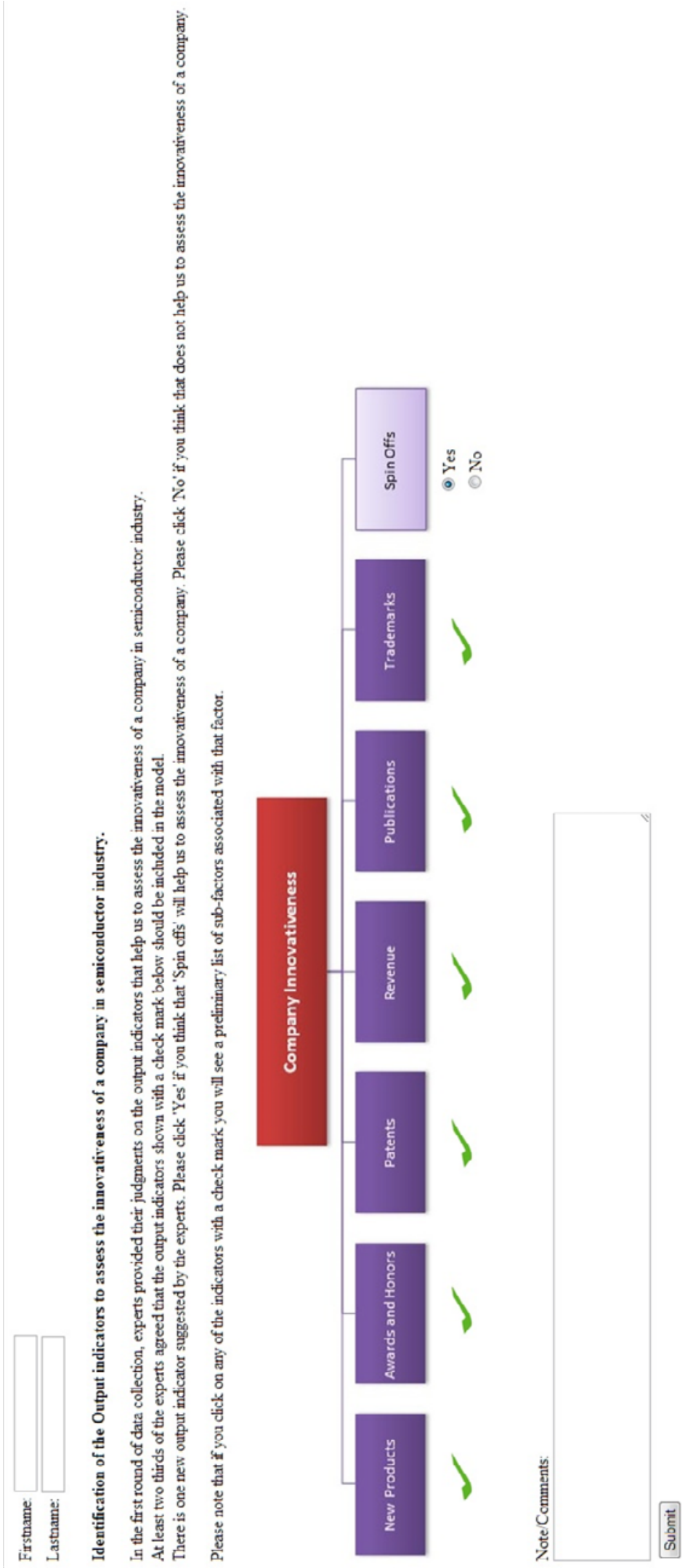


Appendix A-5: Research Instrument 5

\section{$\underline{\text { Data Collection for Relative Importance - Output Indicators }}$}

Dear Dr. X,

After several rounds of data collection with the experts from Academia, Industry, and Government, we have finalized the framework that helps us assessing the innovativeness of a company in semiconductor industry.

The output indicators in the framework were approved by at least two thirds of the experts.

I am now asking for quantified expert judgments about the relative importance of each indicator in terms of its contribution to help us assess the innovativeness of a company in semiconductor industry.

Constant sum method will be used for pairwise comparisons of the indicators to determine the importance weight of each indicator.

I will appreciate it if you please go to the following link for the pairwise comparisons. (It will take approximately 3-5 minutes to complete)

http://research1.etm.pdx.edu/HDM2/expert.aspx?id=7dfe278d3437edfd/8f8a05f014b380 b7 

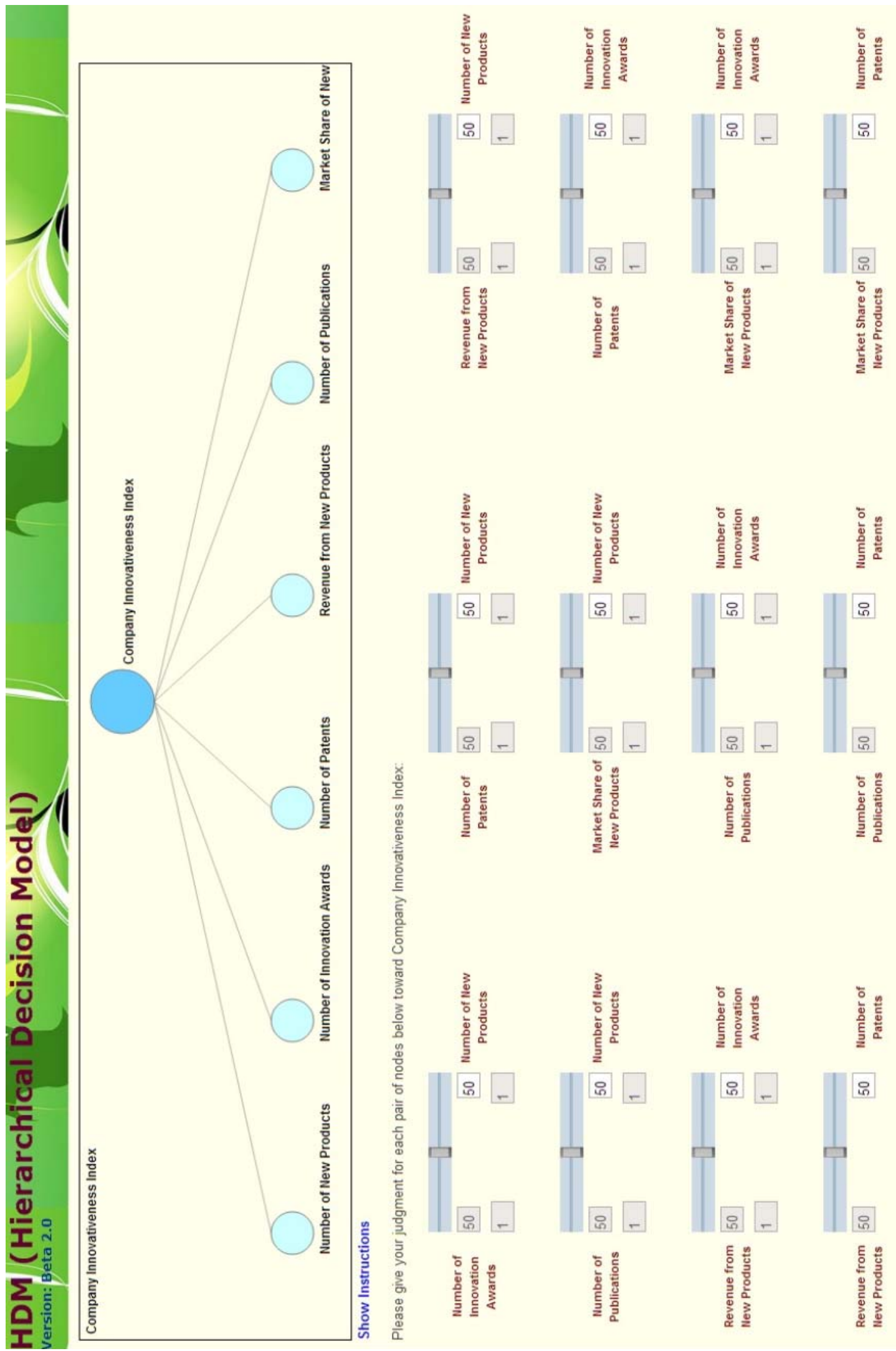
Appendix A-6: Research Instrument 6

\section{Data Collection for Relative Importance - Number of New Products}

Dear Dr. X,

I am now asking for quantified expert judgments about the relative importance of subfactors of each output indicator.

Constant sum method will be used for pairwise comparisons of the indicators to determine the importance weight of each indicator.

I will appreciate it if you please go to the following link for the pairwise comparisons. (It will take approximately 3-5 minutes to complete)

http://research1.etm.pdx.edu/HDM2/expert.aspx?id=7dfe278d3437edfd/bc341608f2f2d6 $\underline{\mathrm{c} 8}$ 


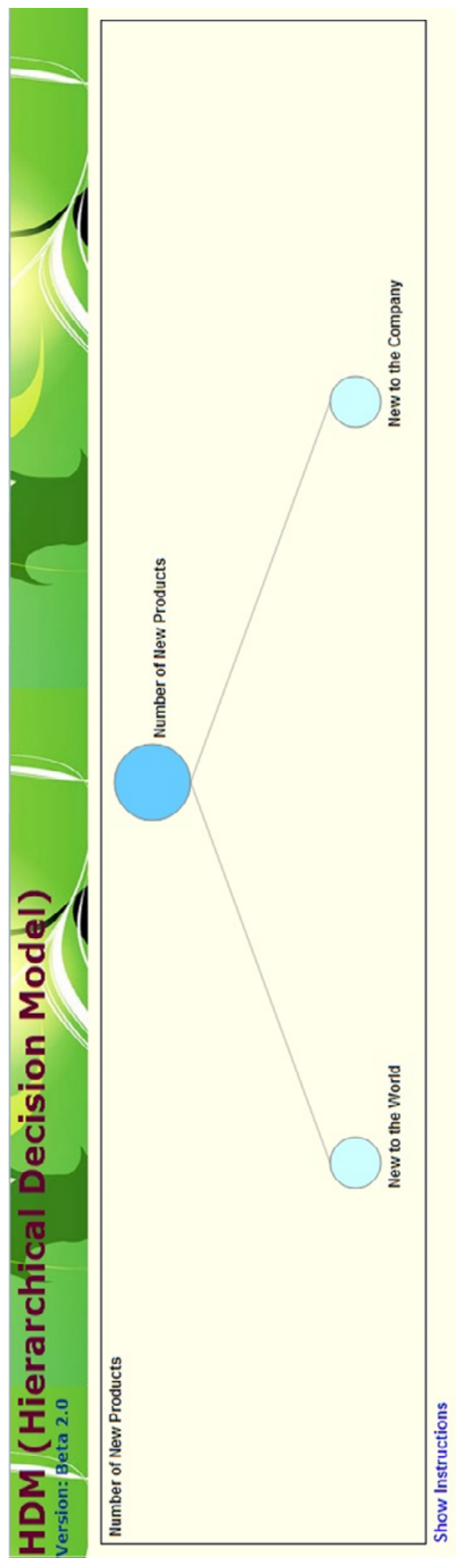

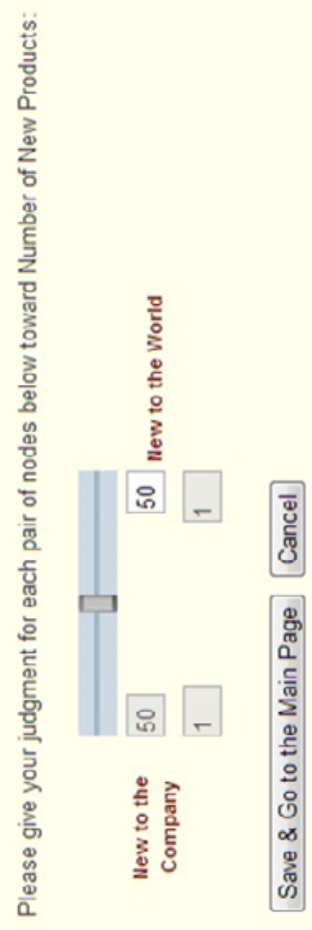


Appendix A-7: Research Instrument 7

Data Collection for Relative Importance - Number of Innovation Awards

Dear Dr. X,

I am now asking for quantified expert judgments about the relative importance of subfactors of each output indicator.

Constant sum method will be used for pairwise comparisons of the indicators to determine the importance weight of each indicator.

I will appreciate it if you please go to the following link for the pairwise comparisons. (It will take approximately 3-5 minutes to complete)

http://research1.etm.pdx.edu/HDM2/expert.aspx?id=7dfe278d3437edfd/76bf879dc6a5d4 $\underline{77}$ 


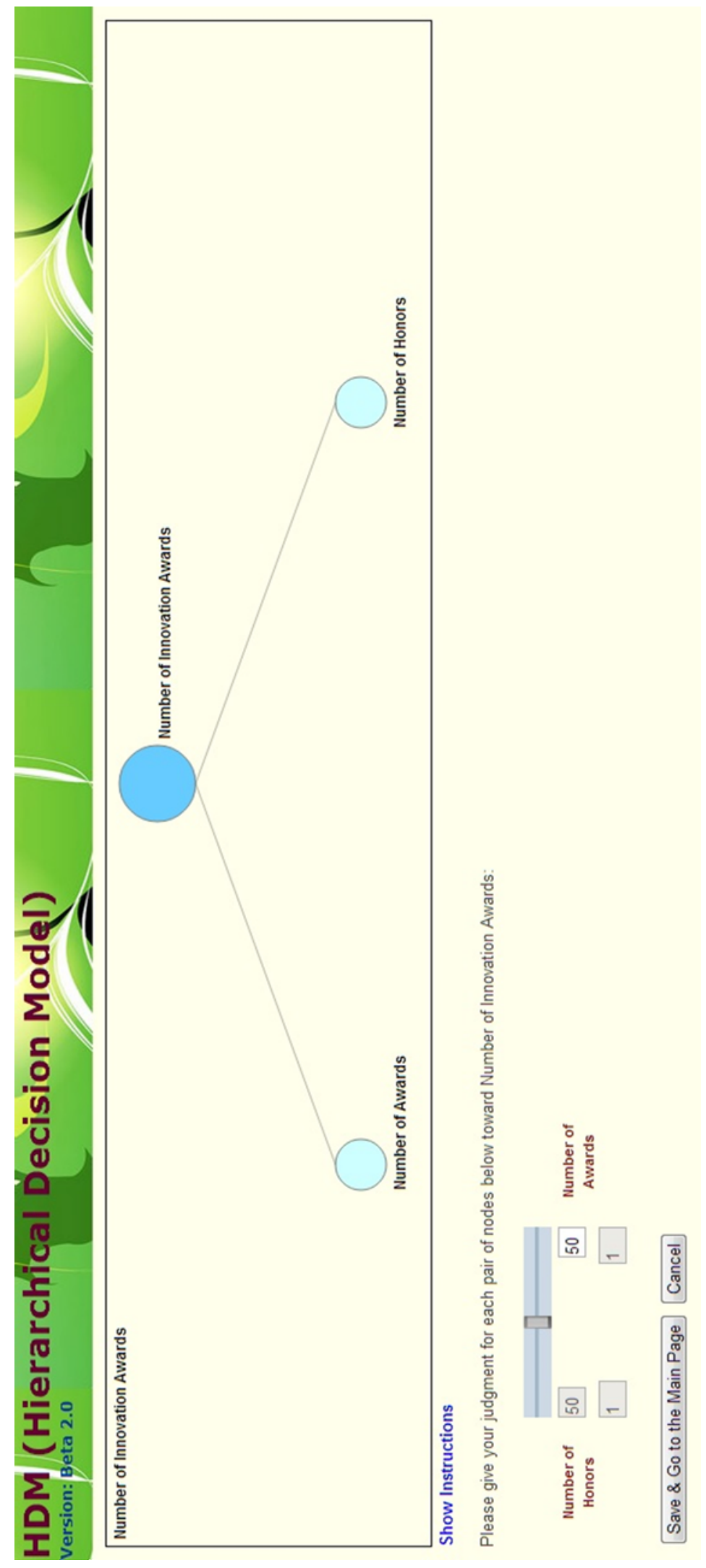


Appendix A-8: Research Instrument 8

\title{
Data Collection for Relative Importance - Number of Patents
}

\author{
Dear Dr. X,
}

I am now asking for quantified expert judgments about the relative importance of subfactors of each output indicator.

Constant sum method will be used for pairwise comparisons of the indicators to determine the importance weight of each indicator.

I will appreciate it if you please go to the following link for the pairwise comparisons. (It will take approximately 3-5 minutes to complete)

http://research1.etm.pdx.edu/HDM2/expert.aspx?id=7dfe278d3437edfd/6754e767bda424 $\underline{69}$ 


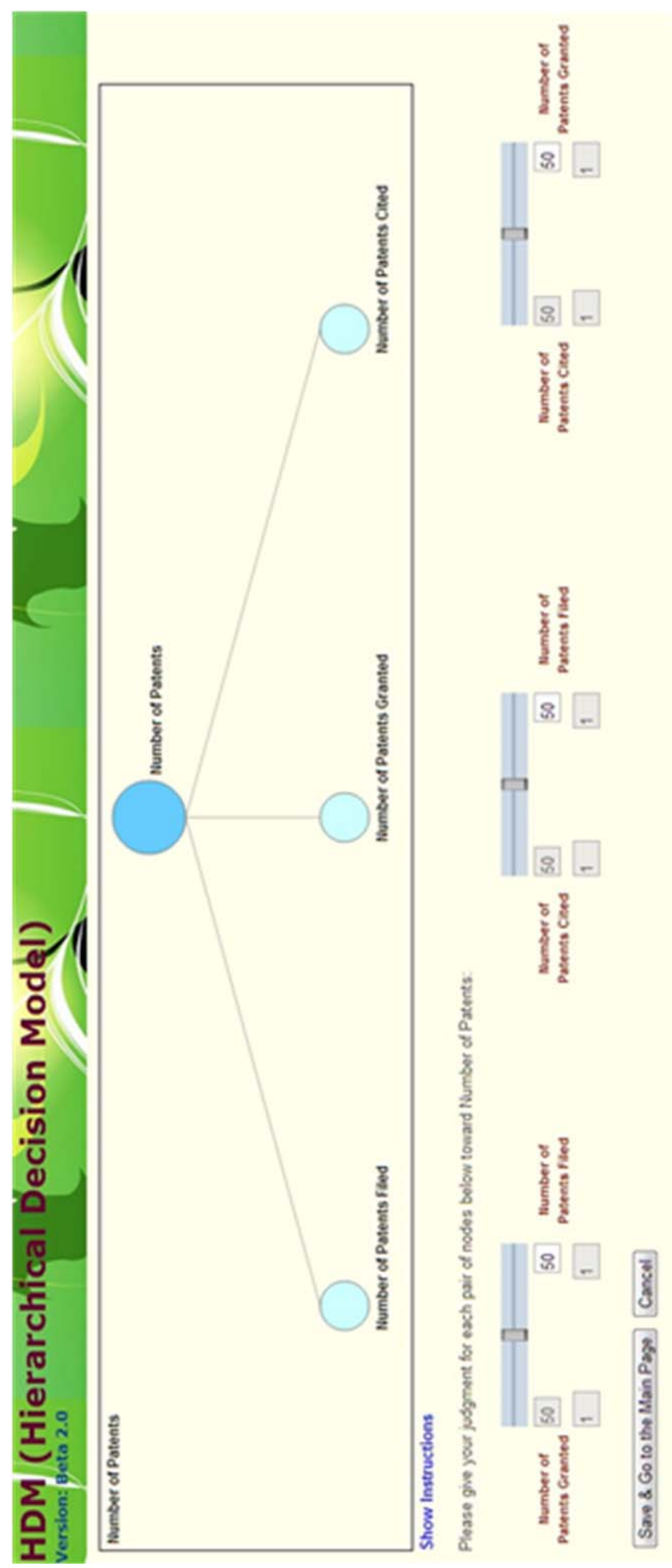


Appendix A-9: Research Instrument 9

\section{Data Collection for Relative Importance - Number of Publications}

Dear Dr. X,

I am now asking for quantified expert judgments about the relative importance of subfactors of each output indicator.

Constant sum method will be used for pairwise comparisons of the indicators to determine the importance weight of each indicator.

I will appreciate it if you please go to the following link for the pairwise comparisons. (It will take approximately 3-5 minutes to complete)

http://research1.etm.pdx.edu/HDM2/expert.aspx?id=7dfe278d3437edfd/84a4225cd33426 e9 


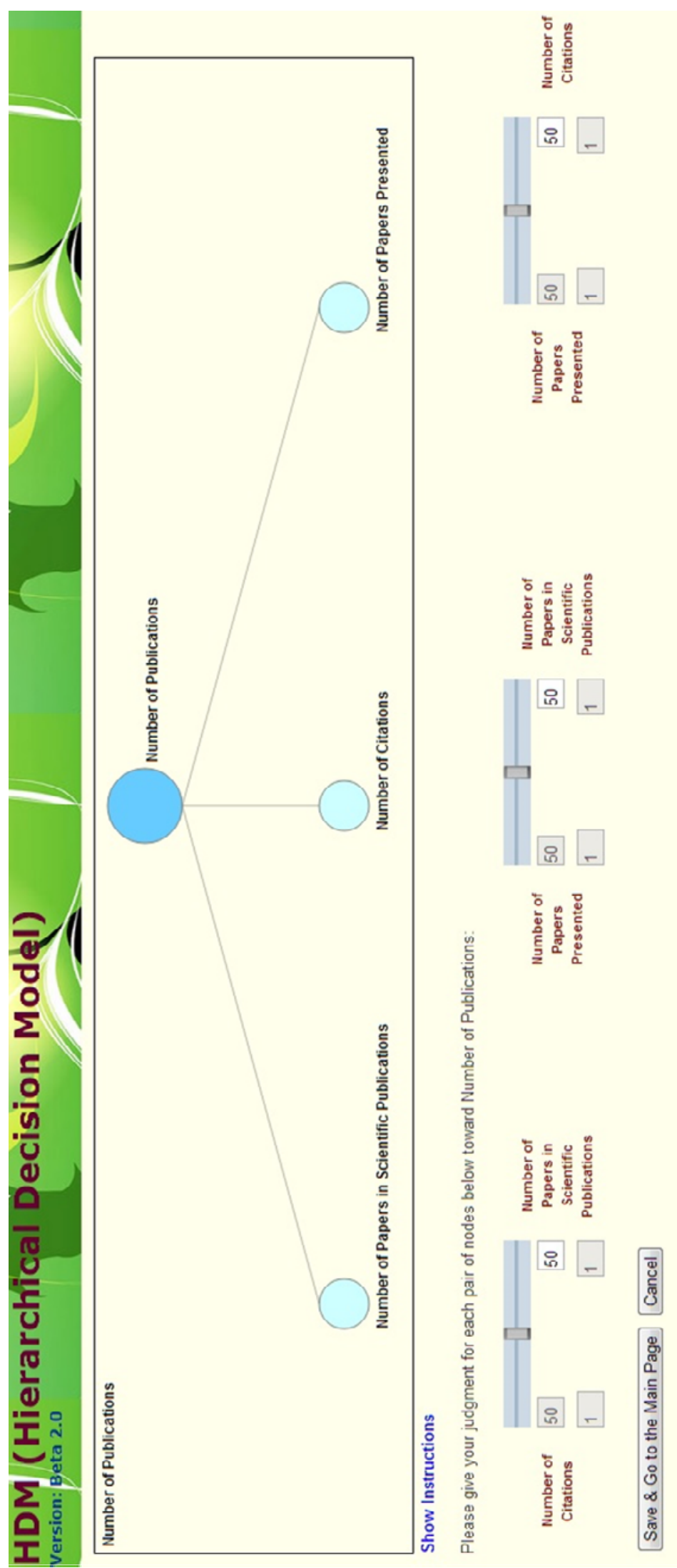


Appendix A-10: Research Instrument 10

\section{Data Collection for Desirability Value - Number of New Products}

FIRST NAME:

\section{LAST NAME:}

\section{Development of Desirability Curves}

Desirability Curve represents how desirable a metric is for the decision maker. In strategic decision making, decisions are often based not on numerical values of the variables but the 'goodness' or usefulness of those values. They are called desirability values of the variables. The objective of this part of the research is to develop desirability curves based on expert judgments.

The use of desirability values normalizes the different units of the metrics in the model, which enables the calculation of the Innovativeness Index.

\section{Illustration:}

The desirability values vary between 0 (least desirable) and 100 (most desirable)

The experts express their opinion by sliding the bar for each level for the metric to indicate the relative desirability of that level. The relationship between the metric and its desirability may or may not be linear.

As an example, suppose an expert has evaluated the desirability of the various levels of the ratio of revenues from new products to total revenues of the company as follow:

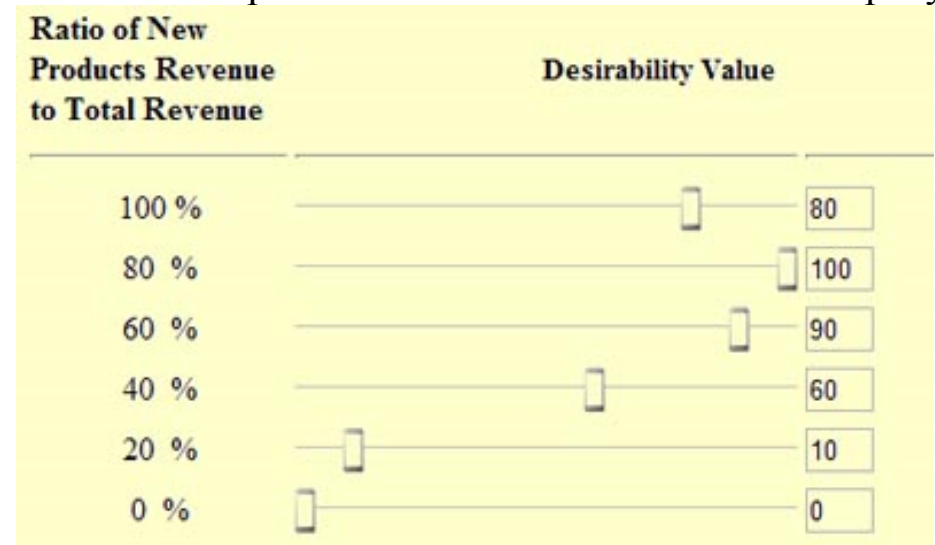

a) According to this expert, the desirability of $100 \%$ of revenues coming from new products is 80

b) According to this expert, the desirability of $80 \%$ of revenues coming from new products is 100 
c) According to this expert, the desirability of $60 \%$ of revenues coming from new products is 90

d) According to this expert, the desirability of $40 \%$ of revenues coming from new products is 60

e) According to this expert, the desirability of $20 \%$ of revenues coming from new products is 10

f) According to this expert, the desirability of $0 \%$ of revenues coming from new products is 0

\section{Please develop desirability curves for new products, below}

\section{Number of New Products that are new to the world in the last 3 years}

The metric for this variable is the number of new products that are new to the world developed by the company, as a percentage of the total number of products of the company in the last three years.

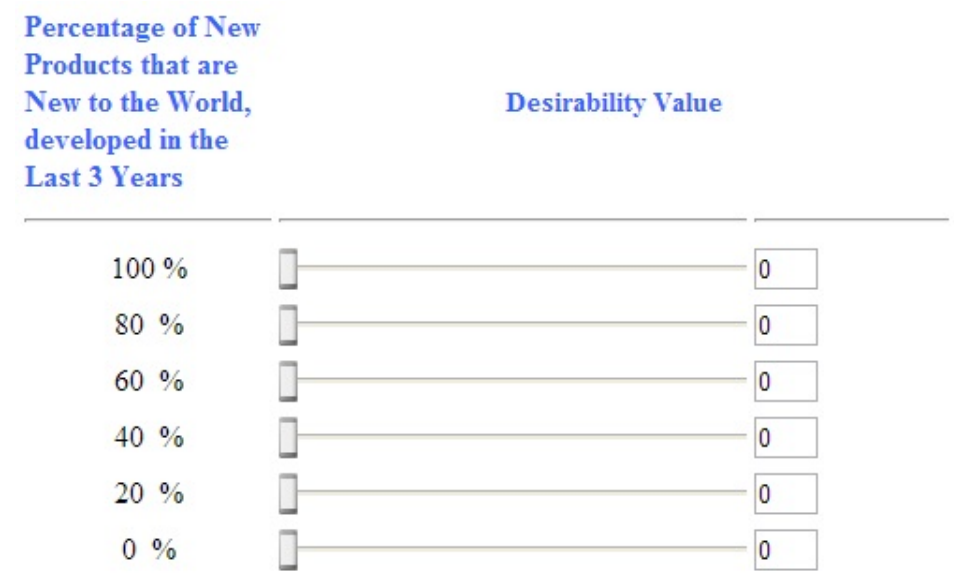

Number of New Products that are new to the company in the last 3 years

The metric for this variable is the number of new products that are new to the company, as a percentage of the total number of products of the company in the last three years. 
Percentage of New

Products that are

New to the

Company,

Desirability Value

developed in the

Last 3 Years

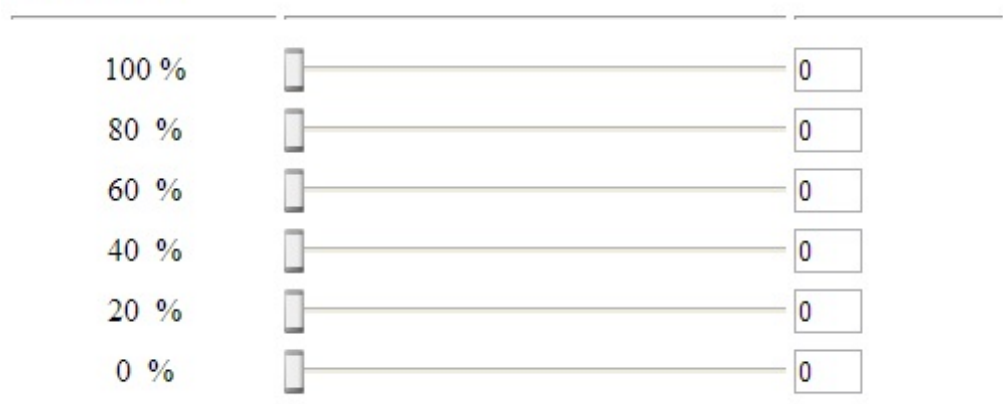

Appendix A-11: Research Instrument 11

\section{$\underline{\text { Data Collection for Desirability Value - Number of Innovation Awards }}$}

FIRST NAME:

LAST NAME:

\section{Development of Desirability Curves}

Desirability Curve represents how desirable a metric is for the decision maker. In strategic decision making, decisions are often based not on numerical values of the variables but the 'goodness' or usefulness of those values. They are called desirability values of the variables. The objective of this part of the research is to develop desirability curves based on expert judgments.

The use of desirability values normalizes the different units of the metrics in the model, which enables the calculation of the Innovativeness Index.

\section{Illustration:}

The desirability values vary between 0 (least desirable) and 100 (most desirable)

The experts express their opinion by sliding the bar for each level for the metric to indicate the relative desirability of that level. The relationship between the metric and its desirability may or may not be linear.

As an example, suppose an expert has evaluated the desirability of the various levels of the ratio of revenues from new products to total revenues of the company as follow: 


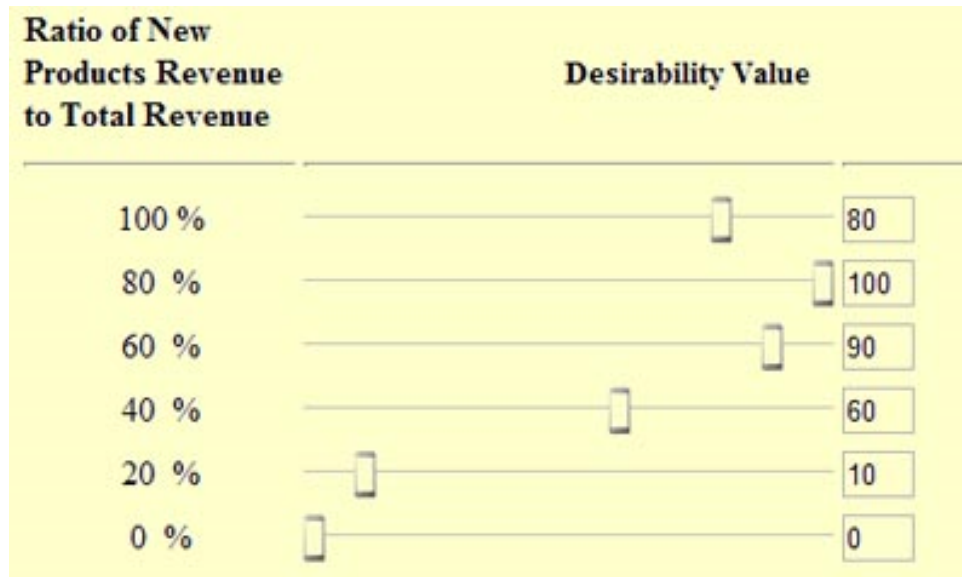

a) According to this expert, the desirability of $100 \%$ of revenues coming from new products is 80

b) According to this expert, the desirability of $80 \%$ of revenues coming from new products is 100

c) According to this expert, the desirability of $60 \%$ of revenues coming from new products is 90

d) According to this expert, the desirability of $40 \%$ of revenues coming from new products is 60

e) According to this expert, the desirability of $20 \%$ of revenues coming from new products is 10

f) According to this expert, the desirability of $0 \%$ of revenues coming from new products is 0

\section{Please develop desirability curves for new products, below}

\section{Innovation Awards in the last 3 years}

The metric for this variable is the number of innovation awards received by the company in the last three years per researcher in the company.

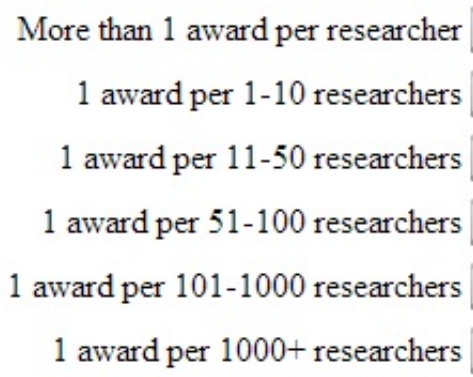

0

0

0

0

0

0 


\section{Innovation Honors in the last 3 years}

The metric for this variable is the number of innovation honors received by the company in the last three years per researcher in company.

Innovation Honors in the Last 3 Years Desirability Value

\begin{tabular}{cc|}
$\begin{array}{c}\text { More than } 1 \text { honor per researcher } \\
1 \text { honor per } 1-10 \text { researchers }\end{array}$ & 0 \\
1 honor per $11-50$ researchers & 0 \\
1 honor per $51-100$ researchers & 0 \\
1 honor per $101-1000$ researchers & 0 \\
1 honor per $1000+$ researchers & 0
\end{tabular}


Appendix A-12: Research Instrument 12

\section{$\underline{\text { Data Collection for Desirability Value - Number of Patents }}$}

FIRST NAME:

\section{LAST NAME:}

\section{Development of Desirability Curves}

Desirability Curve represents how desirable a metric is for the decision maker. In strategic decision making, decisions are often based not on numerical values of the variables but the 'goodness' or usefulness of those values. They are called desirability values of the variables. The objective of this part of the research is to develop desirability curves based on expert judgments.

The use of desirability values normalizes the different units of the metrics in the model, which enables the calculation of the Innovativeness Index.

\section{Illustration:}

The desirability values vary between 0 (least desirable) and 100 (most desirable)

The experts express their opinion by sliding the bar for each level for the metric to indicate the relative desirability of that level. The relationship between the metric and its desirability may or may not be linear.

As an example, suppose an expert has evaluated the desirability of the various levels of the ratio of revenues from new products to total revenues of the company as follow:

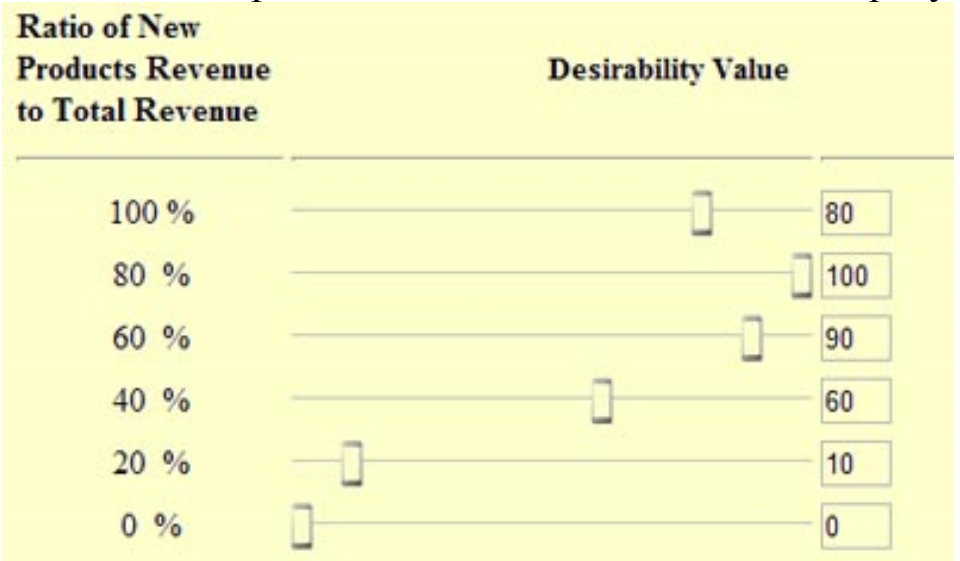

a) According to this expert, the desirability of $100 \%$ of revenues coming from new products is 80

b) According to this expert, the desirability of $80 \%$ of revenues coming from new products is 100

c) According to this expert, the desirability of $60 \%$ of revenues coming from new products is 90 
d) According to this expert, the desirability of $40 \%$ of revenues coming from new products is 60

e) According to this expert, the desirability of $20 \%$ of revenues coming from new products is 10

f) According to this expert, the desirability of $0 \%$ of revenues coming from new products is 0

\section{Patents Filed in the last 3 years}

The metric for this variable is the number of patents filed by the company in the last three years per researcher in the company.

\section{Patents Filed in the Last 3 Years Desirability Value}

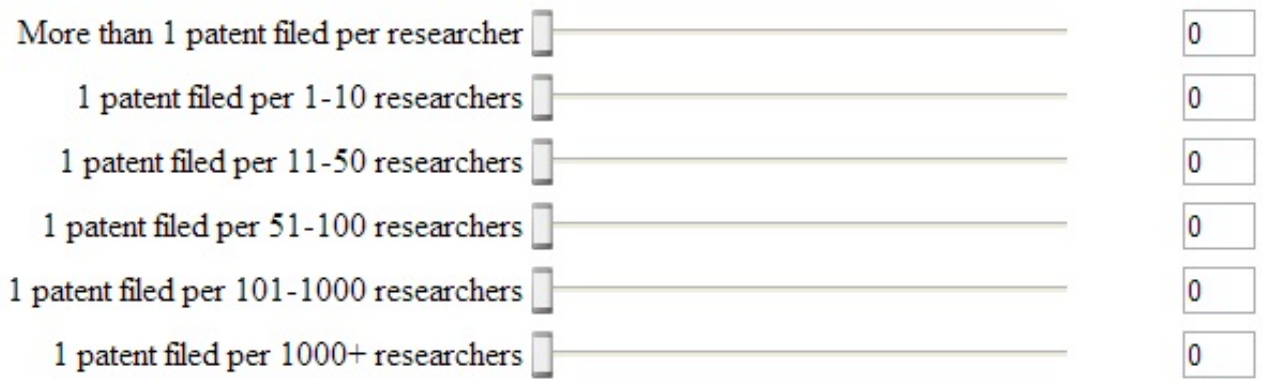

\section{Patents Granted in the last 3 years}

The metric for this variable is the number of patents granted in the last three years per researcher in the company.

\section{0}

0

0

0

0

0 


\section{Patents Cited in the last 3 years}

The metric for this variable is the number of patents cited in the last three years per researcher in the company.
Patents Cited in the Last 3 Years
Desirability Value

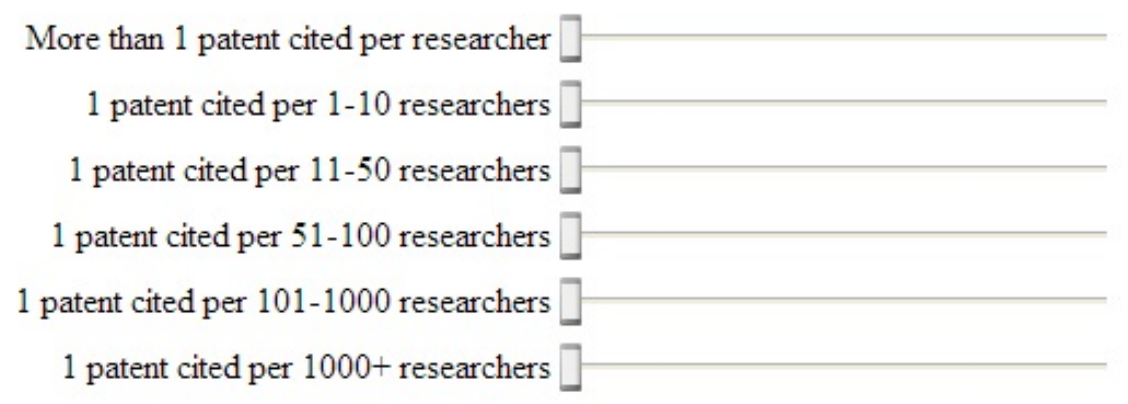

\begin{tabular}{|l|}
\hline 0 \\
\hline 0 \\
\hline 0 \\
\hline 0 \\
\hline 0 \\
\hline 0 \\
\hline
\end{tabular}


Appendix A-13: Research Instrument 13

\section{$\underline{\text { Data Collection for Desirability Value - Revenue from New Products }}$}

FIRST NAME:

\section{LAST NAME:}

\section{Development of Desirability Curves}

Desirability Curve represents how desirable a metric is for the decision maker. In strategic decision making, decisions are often based not on numerical values of the variables but the 'goodness' or usefulness of those values. They are called desirability values of the variables. The objective of this part of the research is to develop desirability curves based on expert judgments.

The use of desirability values normalizes the different units of the metrics in the model, which enables the calculation of the Innovativeness Index.

\section{Illustration:}

The desirability values vary between 0 (least desirable) and 100 (most desirable)

The experts express their opinion by sliding the bar for each level for the metric to indicate the relative desirability of that level. The relationship between the metric and its desirability may or may not be linear.

As an example, suppose an expert has evaluated the desirability of the various levels of the ratio of revenues from new products to total revenues of the company as follow:

\section{Ratio of New \\ Products Revenue \\ to Total Revenue}

Desirability Value

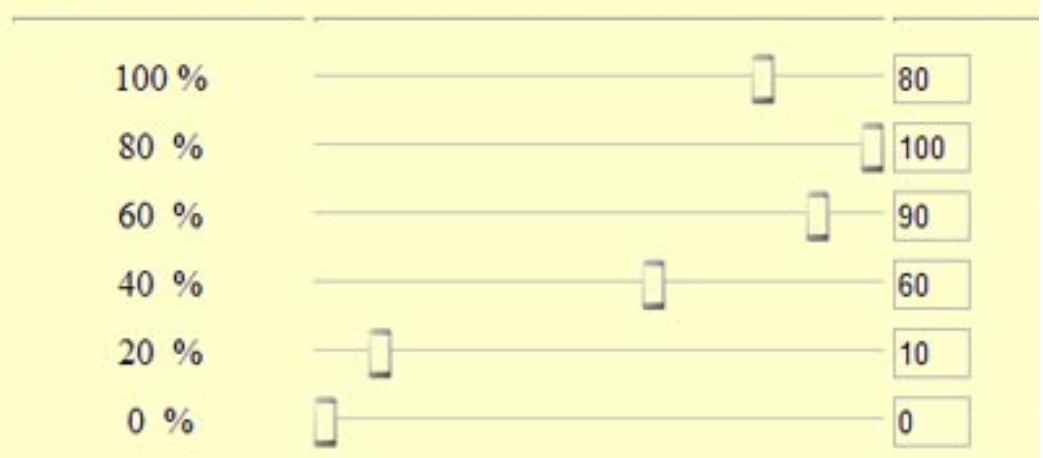

a) According to this expert, the desirability of $100 \%$ of revenues coming from new products is 80

b) According to this expert, the desirability of $80 \%$ of revenues coming from new products is 100 
c) According to this expert, the desirability of $60 \%$ of revenues coming from new products is 90

d) According to this expert, the desirability of $40 \%$ of revenues coming from new products is 60

e) According to this expert, the desirability of $20 \%$ of revenues coming from new products is 10

f) According to this expert, the desirability of $0 \%$ of revenues coming from new products is 0

Please develop desirability curves for revenue from new products in the last 3 years, below

The metric for this variable is the revenue from new products, as a percentage of the total revenue received by the company in the last three years.

Ratio of New

Products Revenue

Desirability Value

to Total Revenue

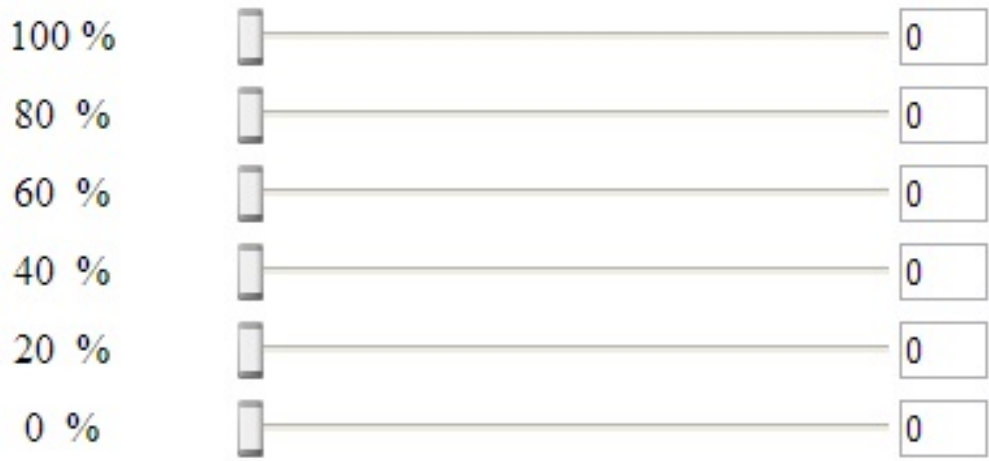


Appendix A-14: Research Instrument 14

\section{$\underline{\text { Data Collection for Desirability Value - Number of Publications }}$}

FIRST NAME:

\section{LAST NAME:}

\section{Development of Desirability Curves}

Desirability Curve represents how desirable a metric is for the decision maker. In strategic decision making, decisions are often based not on numerical values of the variables but the 'goodness' or usefulness of those values. They are called desirability values of the variables. The objective of this part of the research is to develop desirability curves based on expert judgments.

The use of desirability values normalizes the different units of the metrics in the model, which enables the calculation of the Innovativeness Index.

\section{Illustration:}

The desirability values vary between 0 (least desirable) and 100 (most desirable)

The experts express their opinion by sliding the bar for each level for the metric to indicate the relative desirability of that level. The relationship between the metric and its desirability may or may not be linear.

As an example, suppose an expert has evaluated the desirability of the various levels of the ratio of revenues from new products to total revenues of the company as follow:

\section{Ratio of New \\ Products Revenue \\ to Total Revenue}

Desirability Value

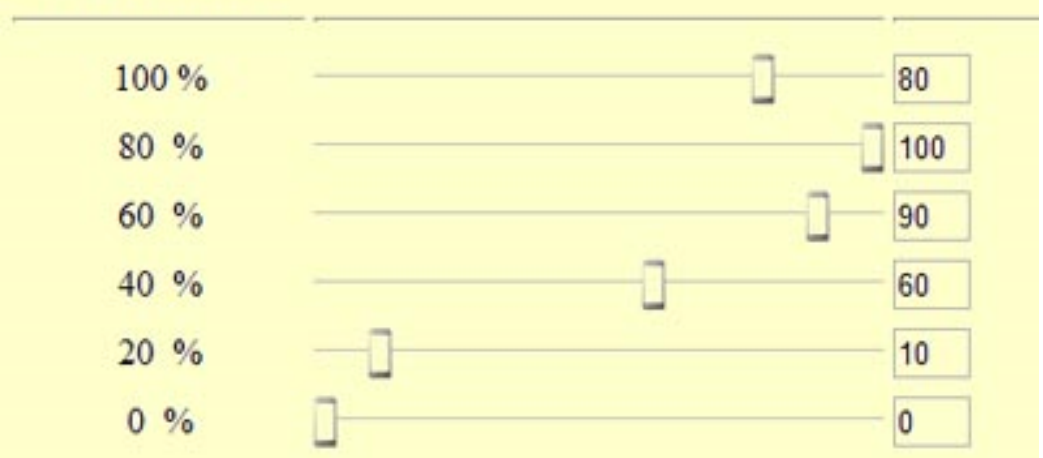

a) According to this expert, the desirability of $100 \%$ of revenues coming from new products is 80

b) According to this expert, the desirability of $80 \%$ of revenues coming from new products is 100 
c) According to this expert, the desirability of $60 \%$ of revenues coming from new products is 90

d) According to this expert, the desirability of $40 \%$ of revenues coming from new products is 60

e) According to this expert, the desirability of $20 \%$ of revenues coming from new products is 10

f) According to this expert, the desirability of $0 \%$ of revenues coming from new products is 0

\section{Papers in Scientific Publications in the last 3 years}

The metric for this variable is the number of papers published in scientific publications in the last three years per researcher in the company.

Papers in Scientific Publications in the Last 3

Years

Desirability Value

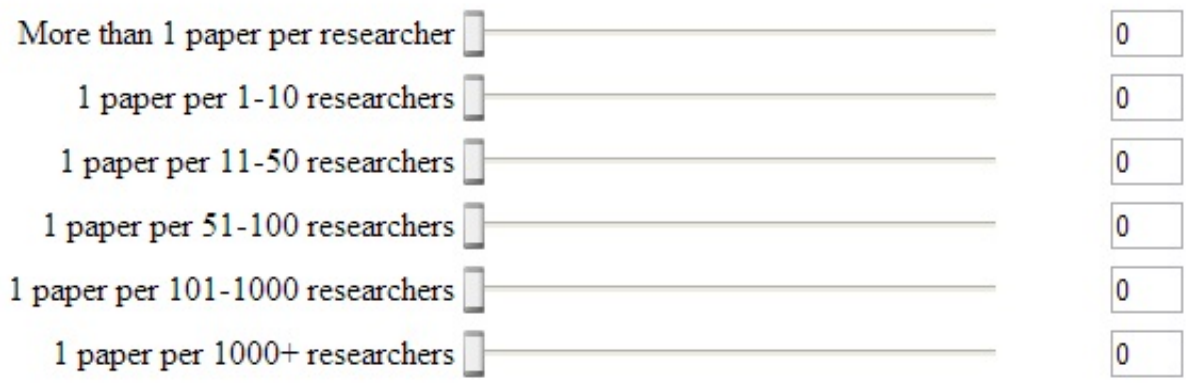

\section{Papers Presented in the last 3 years}

The metric for this variable is the number of papers presented in the last three years per researcher in the company.

\section{Papers Presented in the Last 3 Years \\ Desirability Value}

More than 1 paper presented per researcher

1 paper presented per $1-10$ researchers

1 paper presented per $11-50$ researchers

1 paper presented per $51-100$ researchers

1 paper presented per $101-1000$ researchers

1 paper presented per $1000+$ researchers
0

0

0

0

0

0 


\section{Papers Cited in the last 3 years}

The metric for this variable is the number of papers cited in the last three years per researcher in the company.

Papers Cited in the Last 3 Years
More than 1 paper cited per researcher
1 paper cited per $1-10$ researchers
1 paper cited per $11-50$ researchers
1 paper cited per $51-100$ researchers
1 paper cited per $101-1000$ researchers
1 paper cited per $1000+$ researchers


Appendix A-15: Research Instrument 15

\section{Data Collection for Desirability Value - Market Share of New Products}

FIRST NAME:

\section{LAST NAME:}

\section{Development of Desirability Curves}

Desirability Curve represents how desirable a metric is for the decision maker. In strategic decision making, decisions are often based not on numerical values of the variables but the 'goodness' or usefulness of those values. They are called desirability values of the variables. The objective of this part of the research is to develop desirability curves based on expert judgments.

The use of desirability values normalizes the different units of the metrics in the model, which enables the calculation of the Innovativeness Index.

\section{Illustration:}

The desirability values vary between 0 (least desirable) and 100 (most desirable)

The experts express their opinion by sliding the bar for each level for the metric to indicate the relative desirability of that level. The relationship between the metric and its desirability may or may not be linear.

As an example, suppose an expert has evaluated the desirability of the various levels of the ratio of revenues from new products to total revenues of the company as follow:

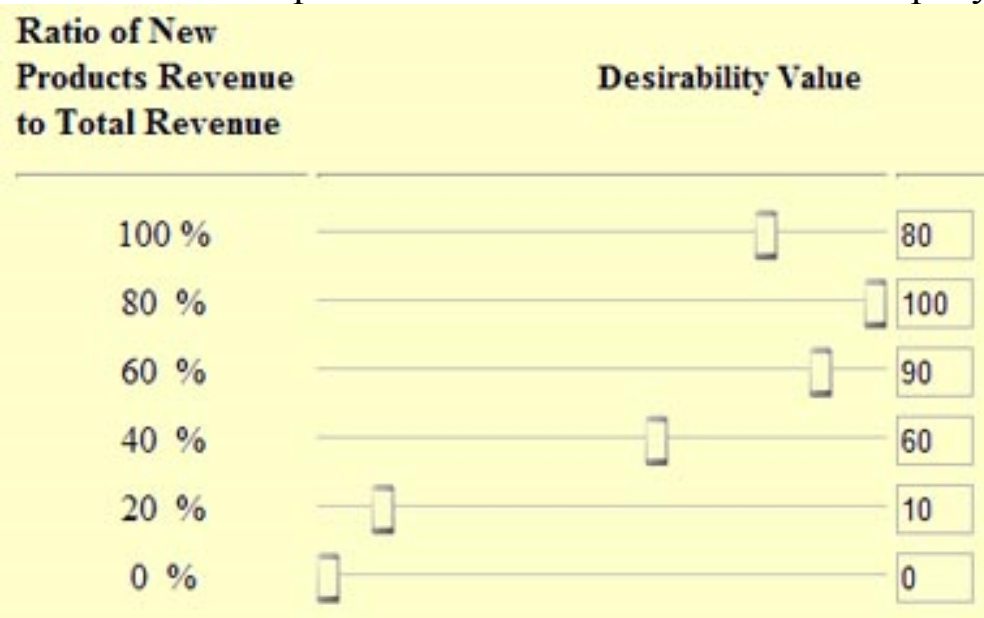

a) According to this expert, the desirability of $100 \%$ of revenues coming from new products is 80

b) According to this expert, the desirability of $80 \%$ of revenues coming from new products is 100 
c) According to this expert, the desirability of $60 \%$ of revenues coming from new products is 90

d) According to this expert, the desirability of $40 \%$ of revenues coming from new products is 60

e) According to this expert, the desirability of $20 \%$ of revenues coming from new products is 10

f) According to this expert, the desirability of $0 \%$ of revenues coming from new products is 0

Please develop the desirability curves for the Market Share of innovative products, below

The metric for this variable is the highest market share of the new product developed by the company in the last three years. (For example, suppose a company has developed 4 new products in the last 3 years and the highest share they have achived in their market since introduction have been $15 \%, 10 \%, 80 \%, 30 \%$ respectively. The metric used for this variable is $80 \%$ )

\section{Highest Percentage of Market Share in the Last 3 Years}

$100 \%$
$80 \%$
$60 \%$
$40 \%$
$20 \%$
$0 \%$

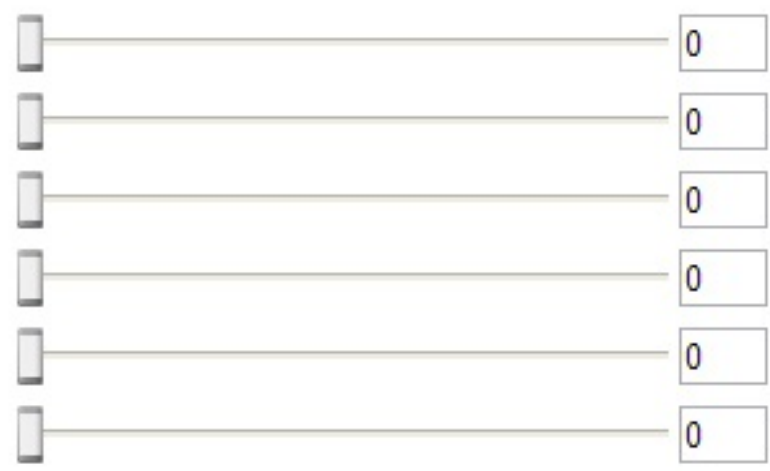




\section{APPENDIX B: JUDGMENT QUANTIFICATIONS}


Appendix B-1: Judgment Quantification of Output Indicators

The table only shows the first part of the ratio. For example if A : B $=80: 20$, only 80 is shown.

\begin{tabular}{|c|c|c|c|c|c|c|c|c|c|c|c|c|c|c|c|}
\hline & $\mathrm{A}: \mathrm{B}$ & $\mathrm{A}: \mathrm{C}$ & A:D & $\mathrm{A}: \mathrm{E}$ & $\mathrm{A}: \mathrm{F}$ & B:C & B:D & B:E & B:F & C:D & $\mathrm{C}: \mathrm{E}$ & C:F & $\mathrm{D}: \mathrm{E}$ & $\mathrm{D}: \mathrm{F}$ & E:F \\
\hline EX1 & 80 & 61 & 30 & 80 & 40 & 33 & 10 & 70 & 10 & 20 & 29 & 17 & 93 & 39 & 11 \\
\hline EX2 & 95 & 12 & 13 & 95 & 21 & 20 & 4 & 24 & 1 & 6 & 79 & 11 & 50 & 50 & 50 \\
\hline EX3 & 60 & 60 & 30 & 90 & 40 & 50 & 20 & 50 & 25 & 30 & 60 & 40 & 70 & 45 & 30 \\
\hline EX4 & 60 & 30 & 60 & 50 & 40 & 50 & 40 & 60 & 40 & 30 & 80 & 40 & 60 & 80 & 50 \\
\hline EX5 & 88 & 68 & 31 & 91 & 50 & 34 & 10 & 55 & 33 & 21 & 70 & 23 & 78 & 69 & 26 \\
\hline EX6 & 60 & 66 & 60 & 75 & 33 & 50 & 40 & 80 & 40 & 40 & 80 & 40 & 80 & 40 & 20 \\
\hline EX7 & 79 & 75 & 30 & 74 & 58 & 36 & 18 & 65 & 19 & 19 & 74 & 19 & 85 & 69 & 25 \\
\hline EX8 & 99 & 80 & 50 & 82 & 67 & 20 & 16 & 41 & 10 & 16 & 80 & 25 & 81 & 50 & 11 \\
\hline EX9 & 85 & 70 & 50 & 85 & 50 & 25 & 10 & 40 & 10 & 35 & 80 & 40 & 90 & 70 & 20 \\
\hline EX10 & 81 & 92 & 77 & 33 & 91 & 21 & 6 & 70 & 35 & 34 & 71 & 37 & 63 & 68 & 38 \\
\hline EX11 & 90 & 50 & 40 & 80 & 50 & 1 & 20 & 50 & 10 & 50 & 90 & 50 & 90 & 60 & 20 \\
\hline EX12 & 93 & 93 & 54 & 90 & 91 & 35 & 29 & 65 & 40 & 23 & 65 & 68 & 63 & 68 & 45 \\
\hline EX13 & 73 & 75 & 73 & 90 & 82 & 43 & 39 & 37 & 43 & 39 & 58 & 72 & 67 & 71 & 41 \\
\hline EX14 & 80 & 75 & 21 & 74 & 16 & 65 & 15 & 29 & 12 & 14 & 24 & 11 & 50 & 50 & 10 \\
\hline EX15 & 91 & 91 & 35 & 96 & 91 & 27 & 12 & 70 & 24 & 12 & 75 & 23 & 92 & 74 & 15 \\
\hline EX16 & 34 & 40 & 35 & 61 & 65 & 65 & 48 & 61 & 64 & 60 & 60 & 69 & 62 & 71 & 39 \\
\hline EX17 & 75 & 60 & 25 & 70 & 35 & 30 & 20 & 40 & 30 & 35 & 50 & 30 & 80 & 60 & 30 \\
\hline EX18 & 93 & 15 & 71 & 63 & 40 & 7 & 22 & 21 & 17 & 56 & 78 & 64 & 68 & 32 & 18 \\
\hline EX19 & 60 & 70 & 25 & 65 & 70 & 70 & 23 & 70 & 32 & 21 & 60 & 30 & 84 & 65 & 20 \\
\hline EX20 & 50 & 50 & 10 & 67 & 25 & 50 & 20 & 66 & 34 & 20 & 50 & 33 & 67 & 34 & 25 \\
\hline EX21 & 34 & 20 & 33 & 60 & 40 & 30 & 25 & 80 & 30 & 40 & 80 & 30 & 90 & 75 & 30 \\
\hline EX22 & 43 & 47 & 43 & 55 & 63 & 47 & 40 & 44 & 48 & 44 & 52 & 42 & 59 & 50 & 43 \\
\hline EX23 & 50 & 62 & 38 & 71 & 70 & 50 & 21 & 50 & 32 & 32 & 37 & 35 & 75 & 79 & 33 \\
\hline EX24 & 10 & 10 & 10 & 50 & 25 & 75 & 25 & 75 & 10 & 10 & 75 & 10 & 90 & 25 & 10 \\
\hline EX25 & 40 & 25 & 40 & 60 & 30 & 40 & 30 & 70 & 40 & 50 & 70 & 50 & 70 & 50 & 30 \\
\hline EX26 & 65 & 75 & 25 & 75 & 50 & 50 & 25 & 50 & 11 & 25 & 50 & 25 & 75 & 50 & 15 \\
\hline EX27 & 65 & 25 & 75 & 80 & 20 & 50 & 50 & 80 & 30 & 70 & 70 & 40 & 60 & 25 & 20 \\
\hline EX28 & 75 & 40 & 60 & 70 & 60 & 40 & 40 & 40 & 40 & 60 & 75 & 75 & 60 & 60 & 60 \\
\hline EX29 & 10 & 40 & 5 & 70 & 20 & 80 & 20 & 91 & 20 & 20 & 91 & 10 & 90 & 81 & 9 \\
\hline EX30 & 85 & 50 & 20 & 90 & 30 & 15 & 10 & 65 & 20 & 40 & 80 & 35 & 90 & 50 & 16 \\
\hline EX31 & 70 & 78 & 27 & 82 & 72 & 27 & 12 & 50 & 20 & 14 & 61 & 24 & 82 & 68 & 22 \\
\hline EX32 & 40 & 40 & 5 & 67 & 5 & 40 & 10 & 70 & 10 & 40 & 70 & 10 & 99 & 70 & 5 \\
\hline EX33 & 70 & 70 & 23 & 77 & 71 & 39 & 28 & 66 & 33 & 18 & 72 & 21 & 75 & 82 & 32 \\
\hline EX34 & 86 & 75 & 30 & 80 & 45 & 32 & 15 & 65 & 29 & 23 & 74 & 31 & 84 & 73 & 30 \\
\hline EX35 & 61 & 60 & 43 & 61 & 71 & 37 & 38 & 54 & 41 & 37 & 58 & 44 & 61 & 57 & 42 \\
\hline EX36 & 10 & 20 & 20 & 60 & 40 & 70 & 40 & 60 & 60 & 30 & 70 & 20 & 80 & 80 & 30 \\
\hline
\end{tabular}


Appendix B-2: Judgment Quantification of Sub-Factors of Number of New Products

The table only shows the first part of the ratio. For example if $A: B=80: 20$, only 80 is shown.

\begin{tabular}{|c|c|}
\hline Experts & $\mathrm{A}: \mathrm{B}$ \\
\hline EX1 & 70 \\
\hline EX2 & 70 \\
\hline EX3 & 68 \\
\hline EX4 & 70 \\
\hline EX5 & 60 \\
\hline EX6 & 60 \\
\hline EX7 & 67 \\
\hline EX8 & 65 \\
\hline EX9 & 70 \\
\hline EX10 & 65 \\
\hline EX11 & 75 \\
\hline EX12 & 50 \\
\hline EX13 & 65 \\
\hline EX14 & 75 \\
\hline EX15 & 60 \\
\hline EX16 & 55 \\
\hline EX17 & 60 \\
\hline EX18 & 70 \\
\hline EX19 & 65 \\
\hline EX20 & 60 \\
\hline EX21 & 70 \\
\hline EX22 & 75 \\
\hline EX23 & 65 \\
\hline EX24 & 60 \\
\hline EX25 & 60 \\
\hline EX26 & 65 \\
\hline EX27 & 70 \\
\hline EX28 & 65 \\
\hline EX29 & 75 \\
\hline EX30 & 68 \\
\hline EX31 & 80 \\
\hline EX32 & 60 \\
\hline EX33 & 70 \\
\hline EX34 & 65 \\
\hline EX35 & 70 \\
\hline
\end{tabular}


Appendix B-3: Judgment Quantification of Sub-Factors of Number of Innovation Awards

The table only shows the first part of the ratio. For example if $\mathrm{A}: \mathrm{B}=80: 20$, only 80 is shown.

\begin{tabular}{|l|c|}
\hline Experts & A:B \\
\hline EX1 & 50 \\
\hline EX2 & 50 \\
\hline EX3 & 50 \\
\hline EX4 & 55 \\
\hline EX5 & 50 \\
\hline EX6 & 50 \\
\hline EX7 & 50 \\
\hline EX8 & 50 \\
\hline EX9 & 50 \\
\hline EX10 & 50 \\
\hline EX11 & 50 \\
\hline EX12 & 50 \\
\hline EX13 & 50 \\
\hline EX14 & 50 \\
\hline EX15 & 50 \\
\hline EX16 & 50 \\
\hline EX17 & 50 \\
\hline EX18 & 50 \\
\hline EX19 & 50 \\
\hline EX20 & 50 \\
\hline EX21 & 50 \\
\hline EX22 & 50 \\
\hline EX23 & 50 \\
\hline EX24 & 50 \\
\hline EX25 & 50 \\
\hline EX26 & 50 \\
\hline EX27 & 50 \\
\hline EX28 & 50 \\
\hline EX29 & 50 \\
\hline EX30 & 55 \\
\hline EX31 & \\
\hline EX32 & 50 \\
\hline EX33 & \\
\hline EX34 & 5 EX35 \\
\hline
\end{tabular}




\section{Appendix B-4: Judgment Quantification of Sub-Factors of Number of Patents}

The table only shows the first part of the ratio. For example if $A: B=80: 20$, only 80 is shown.

\begin{tabular}{|c|c|c|c|}
\hline Experts & A:B & $\mathrm{A}: \mathrm{C}$ & $\mathrm{B}: \mathrm{C}$ \\
\hline EX1 & 30 & 70 & 90 \\
\hline EX2 & 25 & 70 & 83 \\
\hline EX3 & 30 & 70 & 82 \\
\hline EX4 & 30 & 70 & 90 \\
\hline EX5 & 25 & 70 & 85 \\
\hline EX6 & 25 & 73 & 86 \\
\hline EX7 & 35 & 70 & 88 \\
\hline EX8 & 25 & 68 & 83 \\
\hline EX9 & 28 & 70 & 78 \\
\hline EX10 & 26 & 71 & 78 \\
\hline EX11 & 22 & 78 & 73 \\
\hline EX12 & 30 & 70 & 85 \\
\hline EX13 & 35 & 60 & 75 \\
\hline EX14 & 30 & 65 & 75 \\
\hline EX15 & 10 & 85 & 93 \\
\hline EX16 & 35 & 60 & 70 \\
\hline EX17 & 30 & 65 & 75 \\
\hline EX18 & 22 & 67 & 84 \\
\hline EX19 & 30 & 70 & 85 \\
\hline EX20 & 33 & 78 & 84 \\
\hline EX21 & 30 & 60 & 70 \\
\hline EX22 & 30 & 65 & 84 \\
\hline EX23 & 28 & 64 & 73 \\
\hline EX24 & 33 & 64 & 72 \\
\hline EX25 & 30 & 65 & 77 \\
\hline EX26 & 30 & 60 & 75 \\
\hline EX27 & 25 & 40 & 70 \\
\hline EX28 & 36 & 60 & 65 \\
\hline EX29 & 30 & 70 & 70 \\
\hline EX30 & 27 & 73 & 84 \\
\hline EX31 & 30 & 65 & 75 \\
\hline EX32 & 25 & 69 & 79 \\
\hline EX33 & 25 & 65 & 87 \\
\hline EX34 & 25 & 70 & 80 \\
\hline EX35 & 35 & 65 & 72 \\
\hline
\end{tabular}


Appendix B-5: Judgment Quantification of Sub-Factors of Number of Publications

The table only shows the first part of the ratio. For example if A : B = $80: 20$, only 80 is shown.

\begin{tabular}{|l|c|c|c|}
\hline Experts & A:B & A:C & B:C \\
\hline EX1 & 21 & 63 & 28 \\
\hline EX2 & 70 & 40 & 23 \\
\hline EX3 & 76 & 74 & 35 \\
\hline EX4 & 80 & 75 & 31 \\
\hline EX5 & 75 & 40 & 30 \\
\hline EX6 & 72 & 85 & 29 \\
\hline EX7 & 74 & 72 & 34 \\
\hline EX8 & 75 & 65 & 29 \\
\hline EX9 & 81 & 67 & 34 \\
\hline EX10 & 93 & 90 & 6 \\
\hline EX11 & 79 & 70 & 27 \\
\hline EX12 & 80 & 80 & 20 \\
\hline EX13 & 75 & 70 & 35 \\
\hline EX14 & 75 & 70 & 40 \\
\hline EX15 & 80 & 80 & 40 \\
\hline EX16 & 60 & 70 & 60 \\
\hline EX17 & 75 & 70 & 30 \\
\hline EX18 & 65 & 68 & 43 \\
\hline EX19 & 75 & 65 & 40 \\
\hline EX20 & 68 & 75 & 30 \\
\hline EX21 & 65 & 70 & 40 \\
\hline EX22 & 75 & 66 & 37 \\
\hline EX23 & 75 & 77 & 35 \\
\hline EX24 & 73 & 73 & 32 \\
\hline EX25 & 73 & 75 & 31 \\
\hline EX26 & 70 & 70 & 30 \\
\hline EX27 & 70 & 70 & 60 \\
\hline EX28 & 72 & 72 & 45 \\
\hline EX29 & 76 & 65 & 30 \\
\hline EX30 & 75 & 41 \\
\hline EX31 & 70 & 65 \\
\hline EX32 & 72 & 35 \\
\hline EX33 & 70 & 41 \\
\hline EX34 & 60 \\
\hline EX35 & 70 & 60 \\
\hline
\end{tabular}


APPENDIX C: DESIRABILITY VALUES 
Appendix C-1: Desirability Values of Number of New Products

NEW PRODUCTS NEW TO THE COMPANY

\begin{tabular}{|c|l|c|c|c|c|c|c|}
\hline No & \multicolumn{1}{|c|}{ Experts } & $\mathbf{0 \%}$ & $\mathbf{2 0 \%}$ & $\mathbf{4 0 \%}$ & $\mathbf{6 0 \%}$ & $\mathbf{8 0 \%}$ & $\mathbf{1 0 0 \%}$ \\
\hline 1 & EX1 & 20 & 40 & 50 & 70 & 60 & 20 \\
\hline 2 & EX2 & 10 & 30 & 50 & 60 & 90 & 30 \\
\hline 3 & EX3 & 10 & 40 & 90 & 50 & 60 & 0 \\
\hline 4 & EX4 & 23 & 58 & 78 & 53 & 70 & 0 \\
\hline 5 & EX5 & 20 & 30 & 50 & 60 & 40 & 20 \\
\hline
\end{tabular}

NEW PRODUCTS NEW TO THE WORLD

\begin{tabular}{|c|l|c|c|c|c|c|c|}
\hline No & \multicolumn{1}{|c|}{ Experts } & $\mathbf{0 \%}$ & $\mathbf{2 0 \%}$ & $\mathbf{4 0 \%}$ & $\mathbf{6 0 \%}$ & $\mathbf{8 0 \%}$ & $\mathbf{1 0 0 \%}$ \\
\hline 1 & EX1 & 20 & 50 & 60 & 70 & 40 & 20 \\
\hline 2 & EX2 & 30 & 70 & 100 & 90 & 80 & 70 \\
\hline 3 & EX3 & 15 & 40 & 60 & 90 & 40 & 0 \\
\hline 4 & EX4 & 22 & 100 & 70 & 48 & 29 & 10 \\
\hline 5 & EX5 & 10 & 40 & 50 & 80 & 40 & 20 \\
\hline
\end{tabular}


Appendix C-2: Desirability Values of Number of Innovation Awards

NUMBER OF AWARDS

\begin{tabular}{|c|l|c|c|c|c|c|c|}
\hline No & Experts & $\begin{array}{c}>1 \text { per } \\
\text { researcher }\end{array}$ & $\begin{array}{c}\mathbf{1} \text { per 1- } \\
\mathbf{1 0}\end{array}$ & $\begin{array}{c}\mathbf{1} \text { per 11- } \\
\mathbf{5 0}\end{array}$ & $\begin{array}{c}\mathbf{1} \text { Per } \\
\mathbf{5 1 - 1 0 0}\end{array}$ & $\begin{array}{c}\mathbf{1} \text { per 101- } \\
\mathbf{1 0 0 0}\end{array}$ & $\mathbf{1}$ per 1000+ \\
\hline 1 & EX1 & 9 & 27 & 42 & 57 & 73 & 93 \\
\hline 2 & EX2 & 10 & 70 & 50 & 30 & 20 & 0 \\
\hline 3 & EX3 & 20 & 30 & 50 & 70 & 40 & 10 \\
\hline 4 & EX4 & 30 & 60 & 100 & 60 & 30 & 0 \\
\hline
\end{tabular}

NUMBER OF HONORS

\begin{tabular}{|c|l|c|c|c|c|c|c|}
\hline No & Experts & $\begin{array}{c}>1 \text { per } \\
\text { researcher }\end{array}$ & $\begin{array}{c}\mathbf{1} \text { per 1- } \\
\mathbf{1 0}\end{array}$ & $\begin{array}{c}\mathbf{1} \text { per 11- } \\
\mathbf{5 0}\end{array}$ & $\begin{array}{c}\mathbf{1} \text { Per } \\
\mathbf{5 1 - 1 0 0}\end{array}$ & $\begin{array}{c}\mathbf{1} \text { per 101- } \\
\mathbf{1 0 0 0}\end{array}$ & $\mathbf{1}$ per 1000+ \\
\hline 1 & EX1 & 7 & 25 & 44 & 63 & 83 & 96 \\
\hline 2 & EX2 & 20 & 50 & 43 & 48 & 31 & 5 \\
\hline 3 & EX3 & 10 & 40 & 50 & 60 & 45 & 30 \\
\hline 4 & EX4 & 30 & 50 & 70 & 60 & 60 & 0 \\
\hline
\end{tabular}


Appendix C-3: Desirability Values of Number of Patents

NUMBER OF PATENTS FILED

\begin{tabular}{|c|l|c|c|c|c|c|c|}
\hline No & Experts & $\begin{array}{c}>1 \text { per } \\
\text { researcher }\end{array}$ & $\begin{array}{c}\mathbf{1} \text { per 1- } \\
\mathbf{1 0}\end{array}$ & $\begin{array}{c}\mathbf{1} \text { per 11- } \\
\mathbf{5 0}\end{array}$ & $\begin{array}{c}\mathbf{1} \text { Per } \\
\mathbf{5 1 - 1 0 0}\end{array}$ & $\begin{array}{c}\mathbf{1} \text { per 101- } \\
\mathbf{1 0 0 0}\end{array}$ & $\mathbf{1}$ per 1000+ \\
\hline 1 & EX1 & 70 & 65 & 50 & 40 & 30 & 10 \\
\hline 2 & EX2 & 80 & 70 & 60 & 50 & 20 & 10 \\
\hline 3 & EX3 & 85 & 75 & 60 & 50 & 30 & 10 \\
\hline 4 & EX4 & 68 & 68 & 68 & 59 & 35 & 6 \\
\hline 5 & EX5 & 90 & 100 & 50 & 20 & 10 & 0 \\
\hline
\end{tabular}

NUMBER OF PATENTS GRANTED

\begin{tabular}{|c|l|c|c|c|c|c|c|}
\hline No & Experts & $\begin{array}{c}>1 \text { per } \\
\text { researcher }\end{array}$ & $\begin{array}{c}\mathbf{1} \text { per 1- } \\
\mathbf{1 0}\end{array}$ & $\begin{array}{c}\mathbf{1} \text { per 11- } \\
\mathbf{5 0}\end{array}$ & $\begin{array}{c}\mathbf{1} \text { Per } \\
\mathbf{5 1 - 1 0 0}\end{array}$ & $\begin{array}{c}\mathbf{1} \text { per 101- } \\
\mathbf{1 0 0 0}\end{array}$ & $\mathbf{1}$ per 1000+ \\
\hline 1 & EX1 & 80 & 70 & 60 & 50 & 30 & 10 \\
\hline 2 & EX2 & 70 & 60 & 50 & 40 & 20 & 10 \\
\hline 3 & EX3 & 85 & 75 & 65 & 55 & 25 & 15 \\
\hline 4 & EX4 & 70 & 65 & 61 & 65 & 58 & 63 \\
\hline 5 & EX5 & 80 & 100 & 70 & 50 & 20 & 0 \\
\hline
\end{tabular}

NUMBER OF PATENTS CITED

\begin{tabular}{|c|l|c|c|c|c|c|c|}
\hline No & Experts & $\begin{array}{c}>1 \text { per } \\
\text { researcher }\end{array}$ & $\begin{array}{c}\mathbf{1} \text { per 1- } \\
\mathbf{1 0}\end{array}$ & $\begin{array}{c}\mathbf{1} \text { per 11- } \\
\mathbf{5 0}\end{array}$ & $\begin{array}{c}\mathbf{1} \text { Per } \\
\mathbf{5 1 - 1 0 0}\end{array}$ & $\begin{array}{c}\mathbf{1} \text { per 101- } \\
\mathbf{1 0 0 0}\end{array}$ & $\mathbf{1}$ per 1000+ \\
\hline 1 & EX1 & 70 & 60 & 50 & 40 & 20 & 10 \\
\hline 2 & EX2 & 80 & 60 & 40 & 30 & 20 & 10 \\
\hline 3 & EX3 & 85 & 70 & 60 & 55 & 25 & 10 \\
\hline 4 & EX4 & 86 & 83 & 80 & 62 & 27 & 5 \\
\hline 5 & EX5 & 70 & 80 & 100 & 70 & 40 & 20 \\
\hline
\end{tabular}


Appendix C-4: Desirability Values of Number of Publications

NUMBER OF PAPERS PUBLISHED

\begin{tabular}{|c|l|c|c|c|c|c|c|}
\hline No & Experts & $\begin{array}{c}>1 \text { per } \\
\text { researcher }\end{array}$ & $\begin{array}{c}\mathbf{1} \text { per 1- } \\
\mathbf{1 0}\end{array}$ & $\begin{array}{c}\mathbf{1} \text { per 11- } \\
\mathbf{5 0}\end{array}$ & $\begin{array}{c}\mathbf{1} \text { Per } \\
\mathbf{5 1 - 1 0 0}\end{array}$ & $\begin{array}{c}\mathbf{1} \text { per 101- } \\
\mathbf{1 0 0 0}\end{array}$ & $\mathbf{1}$ per 1000+ \\
\hline 1 & EX1 & 0 & 33 & 67 & 100 & 100 & 100 \\
\hline 2 & EX2 & 10 & 50 & 70 & 50 & 30 & 10 \\
\hline 3 & EX3 & 25 & 40 & 50 & 20 & 5 & 0 \\
\hline 4 & EX4 & 0 & 25 & 80 & 40 & 10 & 0 \\
\hline
\end{tabular}

NUMBER OF PAPERS CITED

\begin{tabular}{|c|l|c|c|c|c|c|c|}
\hline No & Experts & $\begin{array}{c}>1 \text { per } \\
\text { researcher }\end{array}$ & $\begin{array}{c}\mathbf{1} \text { per 1- } \\
\mathbf{1 0}\end{array}$ & $\begin{array}{c}\mathbf{1} \text { per 11- } \\
\mathbf{5 0}\end{array}$ & $\begin{array}{c}\mathbf{1} \text { Per } \\
\mathbf{5 1 - 1 0 0}\end{array}$ & $\begin{array}{c}\mathbf{1} \text { per 101- } \\
\mathbf{1 0 0 0}\end{array}$ & $\mathbf{1}$ per 1000+ \\
\hline 1 & EX1 & 0 & 0 & 33 & 67 & 100 & 100 \\
\hline 2 & EX2 & 20 & 40 & 50 & 60 & 30 & 10 \\
\hline 3 & EX3 & 10 & 20 & 40 & 20 & 6 & 0 \\
\hline 4 & EX4 & 0 & 10 & 40 & 20 & 10 & 0 \\
\hline
\end{tabular}

NUMBER OF PAPERS PRESENTED

\begin{tabular}{|c|l|c|c|c|c|c|c|}
\hline No & Experts & $\begin{array}{c}>1 \text { per } \\
\text { researcher }\end{array}$ & $\begin{array}{c}\mathbf{1} \text { per 1- } \\
\mathbf{1 0}\end{array}$ & $\begin{array}{c}\mathbf{1} \text { per 11- } \\
\mathbf{5 0}\end{array}$ & $\begin{array}{c}\mathbf{1} \text { Per } \\
\mathbf{5 1 - 1 0 0}\end{array}$ & $\begin{array}{c}\mathbf{1} \text { per 101- } \\
\mathbf{1 0 0 0}\end{array}$ & $\mathbf{1}$ per 1000+ \\
\hline 1 & EX1 & 0 & 33 & 67 & 100 & 100 & 100 \\
\hline 2 & EX2 & 20 & 50 & 60 & 40 & 30 & 20 \\
\hline 3 & EX3 & 30 & 55 & 40 & 35 & 15 & 0 \\
\hline 4 & EX4 & 15 & 35 & 65 & 55 & 30 & 0 \\
\hline
\end{tabular}


Appendix C-5: Desirability Values of Revenue of New Products

REVENUE OF NEW PRODUCTS

\begin{tabular}{|c|l|c|c|c|c|c|c|}
\hline No & Experts & $\mathbf{0 \%}$ & $\mathbf{2 0 \%}$ & $\mathbf{4 0 \%}$ & $\mathbf{6 0 \%}$ & $\mathbf{8 0 \%}$ & $\mathbf{1 0 0 \%}$ \\
\hline 1 & EX1 & 0 & 40 & 70 & 90 & 50 & 10 \\
\hline 2 & EX2 & 0 & 40 & 65 & 85 & 60 & 0 \\
\hline 3 & EX3 & 0 & 9 & 48 & 85 & 84 & 10 \\
\hline 4 & EX4 & 0 & 30 & 75 & 90 & 65 & 10 \\
\hline 5 & EX5 & 0 & 20 & 50 & 90 & 90 & 70 \\
\hline 6 & EX6 & 0 & 100 & 80 & 40 & 35 & 30 \\
\hline
\end{tabular}


Appendix C-6: Desirability Values of Market Share of New Products

MARKET SHARE OF NEW PRODUCTS

\begin{tabular}{|c|l|c|c|c|c|c|c|}
\hline No & \multicolumn{1}{|c|}{ Experts } & $\mathbf{0 \%}$ & $\mathbf{2 0 \%}$ & $\mathbf{4 0 \%}$ & $\mathbf{6 0 \%}$ & $\mathbf{8 0 \%}$ & $\mathbf{1 0 0 \%}$ \\
\hline 1 & EX1 & 0 & 25 & 40 & 65 & 85 & 40 \\
\hline 2 & EX2 & 0 & 0 & 20 & 60 & 100 & 20 \\
\hline 3 & EX3 & 0 & 10 & 30 & 65 & 95 & 85 \\
\hline 4 & EX4 & 0 & 20 & 50 & 60 & 90 & 40 \\
\hline 5 & EX5 & 0 & 25 & 50 & 80 & 100 & 100 \\
\hline 6 & EX6 & 0 & 30 & 40 & 60 & 80 & 35 \\
\hline
\end{tabular}




\section{APPENDIX D: INNOVATIVENESS INDEX}


Appendix D-1: Innovativeness Index - Baseline Value

CHARACTERISTICS OF THE FIVE HYPOTHETICAL COMPANIES

\begin{tabular}{|l|c|c|c|c|c|}
\hline COMPANY & A & B & C & D & E \\
\hline New Products New to the World & 600 & 24 & 2 & 10 & 6 \\
\hline New Products New to the Company & 800 & 45 & 3 & 18 & 9 \\
\hline Number of Awards & 600 & 20 & 1 & 12 & 7 \\
\hline Number of Honors & 600 & 20 & 4 & 8 & 6 \\
\hline Number of Patents Granted & 600 & 4 & 4 & 8 & 25 \\
\hline Number of Patents Filed & 800 & 4 & 4 & 12 & 30 \\
\hline Number of Patents Cited & 700 & 3 & 4 & 8 & 40 \\
\hline $\begin{array}{l}\text { Revenue from New Products } \\
\text { (in thousands US\$) }\end{array}$ & 480,000 & 160,000 & 3,500 & 20,000 & 400 \\
\hline Number of Papers Published & 50 & 4 & 6 & 72 & 7 \\
\hline Number of Papers Presented & 40 & 2 & 4 & 60 & 7 \\
\hline Number of Papers Cited & 40 & 3 & 10 & 68 & 6 \\
\hline Market Share of New Products & $90 \%$ & $30 \%$ & $60 \%$ & $15 \%$ & $30 \%$ \\
\hline
\end{tabular}

PERFORMANCE METRICS OF THE FIVE HYPOTHETICAL COMPANIES

\begin{tabular}{|c|c|c|c|c|c|}
\hline Sub-Factors & $\mathrm{A}$ & B & $\mathrm{C}$ & $\mathrm{D}$ & $\mathrm{E}$ \\
\hline $\begin{array}{l}\text { New Products New to the } \\
\text { World }\end{array}$ & $60 \%$ & $16 \%$ & $20 \%$ & $8 \%$ & $8 \%$ \\
\hline $\begin{array}{l}\text { New Products New to the } \\
\text { Company }\end{array}$ & $80 \%$ & $30 \%$ & $30 \%$ & $15 \%$ & $12 \%$ \\
\hline Number of Awards & $\begin{array}{l}1 \text { per } 10 \\
\text { researchers }\end{array}$ & $\begin{array}{c}1 \text { per } 12 \\
\text { researchers }\end{array}$ & $\begin{array}{l}1 \text { per } 50 \\
\text { researchers }\end{array}$ & $\begin{array}{l}1 \text { per } 66 \\
\text { researchers }\end{array}$ & $\begin{array}{l}1 \text { per } 10 \\
\text { researchers }\end{array}$ \\
\hline Number of Honors & $\begin{array}{l}1 \text { per } 10 \\
\text { researchers }\end{array}$ & $\begin{array}{l}1 \text { per } 12 \\
\text { researchers }\end{array}$ & $\begin{array}{c}1 \text { per } 12 \\
\text { researchers }\end{array}$ & $\begin{array}{c}1 \text { per } 100 \\
\text { researchers }\end{array}$ & $\begin{array}{c}1 \text { per } 12 \\
\text { researchers }\end{array}$ \\
\hline Number of Patents Granted & $\begin{array}{c}1 \text { per } 10 \\
\text { researcher }\end{array}$ & $\begin{array}{l}1 \text { per } 62 \\
\text { researchers }\end{array}$ & $\begin{array}{c}1 \text { per } 12 \\
\text { researchers }\end{array}$ & $\begin{array}{c}1 \text { per } 100 \\
\text { researchers }\end{array}$ & $\begin{array}{c}1 \text { per } 3 \\
\text { researchers }\end{array}$ \\
\hline Number of Patents Filed & $\begin{array}{l}1 \text { per } 7 \\
\text { researchers }\end{array}$ & $\begin{array}{c}1 \text { per } 62 \\
\text { researchers }\end{array}$ & $\begin{array}{c}1 \text { per } 12 \\
\text { researchers }\end{array}$ & $\begin{array}{l}1 \text { per } 66 \\
\text { researchers }\end{array}$ & $\begin{array}{c}1 \text { per } 2 \\
\text { researchers }\end{array}$ \\
\hline Number of Patents Cited & $\begin{array}{c}1 \text { per } 8 \\
\text { researchers }\end{array}$ & $\begin{array}{c}1 \text { per } 83 \\
\text { researchers }\end{array}$ & $\begin{array}{c}1 \text { per } 12 \\
\text { researchers }\end{array}$ & $\begin{array}{l}1 \text { per } 100 \\
\text { researchers }\end{array}$ & $\begin{array}{c}1 \text { per } 2 \\
\text { researchers }\end{array}$ \\
\hline $\begin{array}{l}\text { Revenue from New } \\
\text { Products }\end{array}$ & $60 \%$ & $20 \%$ & $35 \%$ & $10 \%$ & $20 \%$ \\
\hline $\begin{array}{l}\text { Number of Papers } \\
\text { Published }\end{array}$ & $\begin{array}{l}1 \text { per } 120 \\
\text { researchers }\end{array}$ & $\begin{array}{c}1 \text { per } 62 \\
\text { researchers }\end{array}$ & $\begin{array}{c}1 \text { per } 8 \\
\text { researchers }\end{array}$ & $\begin{array}{l}1 \text { per } 11 \\
\text { researchers }\end{array}$ & $\begin{array}{l}1 \text { per } 10 \\
\text { researchers }\end{array}$ \\
\hline $\begin{array}{l}\text { Number of Papers } \\
\text { Presented }\end{array}$ & $\begin{array}{l}1 \text { per } 150 \\
\text { researchers }\end{array}$ & $\begin{array}{c}1 \text { per } 125 \\
\text { researchers }\end{array}$ & $\begin{array}{c}1 \text { per } 12 \\
\text { researchers }\end{array}$ & $\begin{array}{c}1 \text { per } 13 \\
\text { researchers }\end{array}$ & $\begin{array}{c}1 \text { per } 10 \\
\text { researchers }\end{array}$ \\
\hline Number of Papers Cited & $\begin{array}{l}1 \text { per } 150 \\
\text { researchers }\end{array}$ & $\begin{array}{l}1 \text { per } 83 \\
\text { researchers }\end{array}$ & $\begin{array}{l}1 \text { per } 5 \\
\text { researchers }\end{array}$ & $\begin{array}{l}1 \text { per } 11 \\
\text { researchers }\end{array}$ & $\begin{array}{l}1 \text { per } 12 \\
\text { researchers }\end{array}$ \\
\hline $\begin{array}{l}\text { Market Share of New } \\
\text { Products }\end{array}$ & $90 \%$ & $30 \%$ & $60 \%$ & $15 \%$ & $30 \%$ \\
\hline
\end{tabular}




\section{DESIRABILITY VALUES OF THE PERFORMANCE METRICS OF THE FIVE}

HYPOTHETICAL COMPANIES

\begin{tabular}{|l|c|c|c|c|c|}
\hline Sub-Factors & A & B & C & D & E \\
\hline New Products New to the World & $\mathbf{7 5}$ & 50 & 60 & 30 & 35 \\
\hline New Products New to the Company & $\mathbf{6 5}$ & 55 & 50 & 35 & 30 \\
\hline Number of Awards & 40 & $\mathbf{6 5}$ & 50 & 40 & 40 \\
\hline Number of Honors & 40 & $\mathbf{5 5}$ & 50 & 45 & 40 \\
\hline Number of Patents Granted & $\mathbf{7 0}$ & 50 & 60 & 45 & $\mathbf{7 0}$ \\
\hline Number of Patents Filed & 70 & 45 & 60 & 50 & $\mathbf{7 5}$ \\
\hline Number of Patents Cited & 70 & 40 & 60 & 40 & $\mathbf{7 0}$ \\
\hline Revenue from New Products & $\mathbf{8 0}$ & 40 & 60 & 20 & 40 \\
\hline Number of Papers Published & 20 & 30 & 45 & $\mathbf{6 5}$ & 30 \\
\hline Number of Papers Presented & 10 & 25 & 45 & $\mathbf{5 5}$ & 40 \\
\hline Number of Papers Cited & 20 & 25 & 30 & $\mathbf{4 2}$ & 20 \\
\hline Market Share of New Products & $\mathbf{9 0}$ & 30 & 60 & 15 & 30 \\
\hline
\end{tabular}

$=$ Factors that the company are strong at

INNOVATIVENESS INDEX AND RANKINGS OF FIVE HYPOTHETICAL COMPANIES

\begin{tabular}{|l|c|c|c|c|c|c|}
\hline \multicolumn{1}{|c|}{ Sub-Factors } & Weights & $\mathbf{A}$ & $\mathbf{B}$ & $\mathbf{C}$ & $\mathbf{D}$ & $\mathbf{E}$ \\
\hline New to the World & $\mathbf{0 . 1 3}$ & 9.75 & 6.5 & 7.8 & 3.9 & 4.55 \\
\hline New to the Company & 0.07 & 4.55 & 3.85 & 3.5 & 2.45 & 2.1 \\
\hline Number of Awards & 0.05 & 2 & 3.25 & 2.5 & 2 & 2 \\
\hline Number of Honors & 0.05 & 2 & 2.75 & 2.5 & 2.25 & 2 \\
\hline Patents Granted & 0.08 & 5.6 & 4 & 4.8 & 3.6 & 5.6 \\
\hline Patents Filed & 0.04 & 2.8 & 1.8 & 2.4 & 2 & 3 \\
\hline Patents Cited & 0.02 & 1.4 & 0.8 & 1.2 & 0.8 & 1.4 \\
\hline Revenue from New Products & $\mathbf{0 . 2 8}$ & 22.4 & 11.2 & 16.8 & 5.6 & 11.2 \\
\hline Papers Published & 0.04 & 0.8 & 1.2 & 1.8 & 2.6 & 1.2 \\
\hline Papers Presented & 0.02 & 0.2 & 0.5 & 0.9 & 1.1 & 0.8 \\
\hline Papers Cited & 0.01 & 0.2 & 0.25 & 0.3 & 0.42 & 0.2 \\
\hline $\begin{array}{l}\text { Market Share of New } \\
\text { Products }\end{array}$ & $\mathbf{0 . 2 1}$ & 18.9 & 6.3 & 12.6 & 3.15 & 6.3 \\
\hline Sum & 1 & $\mathbf{7 0 . 6}$ & $\mathbf{4 2 . 4}$ & $\mathbf{5 7 . 1}$ & $\mathbf{2 9 . 8 7}$ & $\mathbf{4 0 . 3 5}$ \\
\hline Ranking & & 1 & 3 & 2 & 5 & 4 \\
\hline
\end{tabular}

- Top Priority 
Appendix D-2: Innovativeness Index - Changes in Relative Importance of Sub-factors (Scenario 1)

\begin{tabular}{|c|c|c|c|c|}
\hline $\begin{array}{l}\text { Output } \\
\text { Indicators }\end{array}$ & Value & \multicolumn{2}{|c|}{ Sub-Factors } & $\begin{array}{l}\text { Sub-factors Value to the } \\
\text { Innovativeness Index }\end{array}$ \\
\hline \multirow{2}{*}{$\begin{array}{l}\text { Number of New } \\
\text { Products }\end{array}$} & \multirow[b]{2}{*}{0.01} & New to the World & 0.66 & 0.0066 \\
\hline & & $\begin{array}{l}\text { New to the } \\
\text { Company }\end{array}$ & 0.34 & 0.0034 \\
\hline \multirow{2}{*}{$\begin{array}{l}\text { Number of Innovation } \\
\text { Awards }\end{array}$} & \multirow{2}{*}{0.95} & Number of Awards & 0.5 & 0.475 \\
\hline & & Number of Honors & 0.5 & 0.475 \\
\hline \multirow{3}{*}{ Number of Patents } & \multirow{3}{*}{0.01} & Patents Granted & 0.6 & 0.006 \\
\hline & & Patents Filed & 0.26 & 0.0026 \\
\hline & & Patents Cited & 0.14 & 0.0014 \\
\hline $\begin{array}{l}\text { Revenue From New } \\
\text { Products }\end{array}$ & 0.01 & $\begin{array}{l}\text { Revenue from New } \\
\text { Products }\end{array}$ & 1 & 0.01 \\
\hline \multirow{3}{*}{ Number of Publications } & \multirow{3}{*}{0.01} & Papers Published & 0.55 & 0.0055 \\
\hline & & Papers Presented & 0.27 & 0.0027 \\
\hline & & Papers Cited & 0.17 & 0.0017 \\
\hline $\begin{array}{l}\text { Market Share of New } \\
\text { Products }\end{array}$ & 0.01 & $\begin{array}{l}\text { Market Share of } \\
\text { New Products }\end{array}$ & 1 & 0.01 \\
\hline Total & 1 & & & 1 \\
\hline
\end{tabular}

- Top Priority

INNOVATIVENESS INDEX AND RANKINGS OF FIVE HYPOTHETICAL COMPANIES SCENARIO 1

\begin{tabular}{|l|c|c|c|c|c|c|}
\hline \multicolumn{1}{|c|}{ Sub-Factors } & Weights & A & B & C & D & E \\
\hline New to the World & 0.0066 & 0.495 & 0.33 & 0.396 & 0.198 & 0.231 \\
\hline New to the Company & 0.0034 & 0.221 & 0.187 & 0.17 & 0.119 & 0.102 \\
\hline Number of Awards & $\mathbf{0 . 4 7 5}$ & 19 & 30.875 & 23.75 & 19 & 19 \\
\hline Number of Honors & $\mathbf{0 . 4 7 5}$ & 19 & 26.125 & 23.75 & 21.375 & 19 \\
\hline Patents Granted & 0.006 & 0.42 & 0.3 & 0.36 & 0.27 & 0.42 \\
\hline Patents Filed & 0.0026 & 0.182 & 0.117 & 0.156 & 0.13 & 0.195 \\
\hline Patents Cited & 0.0014 & 0.098 & 0.056 & 0.084 & 0.056 & 0.098 \\
\hline Revenue from New Products & 0.01 & 0.8 & 0.4 & 0.6 & 0.2 & 0.4 \\
\hline Papers Published & 0.0055 & 0.11 & 0.165 & 0.2475 & 0.3575 & 0.165 \\
\hline Papers Presented & 0.0027 & 0.027 & 0.0675 & 0.1215 & 0.1485 & 0.108 \\
\hline Papers Cited & 0.0017 & 0.034 & 0.0425 & 0.051 & 0.0714 & 0.034 \\
\hline Market Share of New Products & 0.01 & 0.9 & 0.3 & 0.6 & 0.15 & 0.3 \\
\hline Sum & 1 & $\mathbf{4 1 . 2 8 7}$ & $\mathbf{5 8 . 9 6 5}$ & $\mathbf{5 0 . 2 8 6}$ & $\mathbf{4 2 . 0 7 5 4}$ & $\mathbf{4 0 . 0 5 3}$ \\
\hline Ranking & & 4 & 1 & 2 & 3 & 5 \\
\hline
\end{tabular}

$=$ Top Priorities 
Appendix D-3: Innovativeness Index - Changes in Relative Importance of sub-factors (Scenario 2)

\section{RELATIVE CONTRIBUTIONS OF SUB-FACTORS TO THE INNOVATIVENESS INDEX - SCENARIO 2}

\begin{tabular}{|c|c|c|c|c|}
\hline $\begin{array}{l}\text { Output } \\
\text { Indicators }\end{array}$ & Value & \multicolumn{2}{|c|}{ Sub-Factors } & $\begin{array}{l}\text { Sub-factors Value to the } \\
\text { Innovativeness Index }\end{array}$ \\
\hline \multirow{2}{*}{$\begin{array}{l}\text { Number of New } \\
\text { Products }\end{array}$} & \multirow[b]{2}{*}{0.01} & New to the World & 0.66 & 0.0066 \\
\hline & & $\begin{array}{l}\text { New to the } \\
\text { Company }\end{array}$ & 0.34 & 0.0034 \\
\hline \multirow{2}{*}{$\begin{array}{l}\text { Number of Innovation } \\
\text { Awards }\end{array}$} & \multirow{2}{*}{0.01} & Number of Awards & 0.5 & 0.005 \\
\hline & & Number of Honors & 0.5 & 0.005 \\
\hline \multirow{3}{*}{ Number of Patents } & \multirow{3}{*}{0.01} & Patents Granted & 0.6 & 0.006 \\
\hline & & Patents Filed & 0.26 & 0.0026 \\
\hline & & Patents Cited & 0.14 & 0.0014 \\
\hline $\begin{array}{l}\text { Revenue From New } \\
\text { Products }\end{array}$ & 0.01 & $\begin{array}{c}\text { Revenue from New } \\
\text { Products }\end{array}$ & 1 & 0.01 \\
\hline \multirow{3}{*}{ Number of Publications } & \multirow{3}{*}{0.95} & Papers Published & 0.55 & 0.5225 \\
\hline & & Papers Presented & 0.27 & 0.2565 \\
\hline & & Papers Cited & 0.17 & 0.1615 \\
\hline $\begin{array}{l}\text { Market Share of New } \\
\text { Products }\end{array}$ & 0.01 & $\begin{array}{l}\text { Market Share of } \\
\text { New Products }\end{array}$ & 1 & 0.01 \\
\hline Total & 1 & & & 1 \\
\hline
\end{tabular}

$=$ Top Priority

INNOVATIVENESS INDEX AND RANKINGS OF FIVE HYPOTHETICAL COMPANIES SCENARIO 2

\begin{tabular}{|l|c|c|c|c|c|c|}
\hline Sub-Factors & Weights & A & B & C & D & E \\
\hline New to the World & 0.0066 & 0.495 & 0.33 & 0.396 & 0.198 & 0.231 \\
\hline New to the Company & 0.0034 & 0.221 & 0.187 & 0.17 & 0.119 & 0.102 \\
\hline Number of Awards & 0.005 & 0.2 & 0.325 & 0.25 & 0.2 & 0.2 \\
\hline Number of Honors & 0.005 & 0.2 & 0.275 & 0.25 & 0.225 & 0.2 \\
\hline Patents Granted & 0.006 & 0.42 & 0.3 & 0.36 & 0.27 & 0.42 \\
\hline Patents Filed & 0.0026 & 0.182 & 0.117 & 0.156 & 0.13 & 0.195 \\
\hline Patents Cited & 0.0014 & 0.098 & 0.056 & 0.084 & 0.056 & 0.098 \\
\hline Revenue from New Products & 0.01 & 0.8 & 0.4 & 0.6 & 0.2 & 0.4 \\
\hline Papers Published & $\mathbf{0 . 5 2 2 5}$ & 10.45 & 15.675 & 23.5125 & 33.9625 & 15.675 \\
\hline Papers Presented & $\mathbf{0 . 2 5 6 5}$ & 2.565 & 6.4125 & 11.5425 & 14.1075 & 10.26 \\
\hline Papers Cited & $\mathbf{0 . 1 6 1 5}$ & 3.23 & 4.0375 & 4.845 & 6.783 & 3.23 \\
\hline Market Share of New Products & 0.01 & 0.9 & 0.3 & 0.6 & 0.15 & 0.3 \\
\hline Sum & 1 & $\mathbf{1 9 . 7 6 1}$ & $\mathbf{2 8 . 4 1 5}$ & $\mathbf{4 2 . 7 6 6}$ & $\mathbf{5 6 . 4 0 1}$ & $\mathbf{3 1 . 3 1 1}$ \\
\hline Ranking & & 5 & 4 & 2 & 1 & 3 \\
\hline
\end{tabular}

$=$ Top Priorities 
Appendix D-4: Innovativeness Index - Changes in Relative Importance of sub-factors (Scenario 3)

RELATIVE CONTRIBUTIONS OF SUB-FACTORS TO THE INNOVATIVENESS INDEX SCENARIO 3

\begin{tabular}{|c|c|c|c|c|}
\hline $\begin{array}{l}\text { Output } \\
\text { Indicators }\end{array}$ & Value & \multicolumn{2}{|c|}{ Sub-Factors } & $\begin{array}{l}\text { Sub-factors Value to the } \\
\text { Innovativeness Index }\end{array}$ \\
\hline \multirow{2}{*}{$\begin{array}{l}\text { Number of New } \\
\text { Products }\end{array}$} & \multirow[t]{2}{*}{0.01} & New to the World & 0.66 & 0.0066 \\
\hline & & New to the Company & 0.34 & 0.0034 \\
\hline \multirow{2}{*}{$\begin{array}{l}\text { Number of Innovation } \\
\text { Awards }\end{array}$} & \multirow[t]{2}{*}{0.01} & Number of Awards & 0.5 & 0.005 \\
\hline & & Number of Honors & 0.5 & 0.005 \\
\hline \multirow{3}{*}{ Number of Patents } & \multirow[t]{3}{*}{0.95} & Patents Granted & 0.6 & 0.57 \\
\hline & & Patents Filed & 0.26 & 0.247 \\
\hline & & Patents Cited & 0.14 & 0.133 \\
\hline $\begin{array}{l}\text { Revenue From New } \\
\text { Products }\end{array}$ & 0.01 & $\begin{array}{l}\text { Revenue from New } \\
\text { Products }\end{array}$ & 1 & 0.01 \\
\hline \multirow{3}{*}{ Number of Publications } & \multirow[t]{3}{*}{0.01} & Papers Published & 0.55 & 0.0055 \\
\hline & & Papers Presented & 0.27 & 0.0027 \\
\hline & & Papers Cited & 0.17 & 0.0017 \\
\hline $\begin{array}{l}\text { Market Share of New } \\
\text { Products }\end{array}$ & 0.01 & $\begin{array}{l}\text { Market Share of } \\
\text { New Products }\end{array}$ & 1 & 0.01 \\
\hline Total & 1 & & & 1 \\
\hline
\end{tabular}

$=$ Top Priorities

INNOVATIVENESS INDEX AND RANKINGS OF FIVE HYPOTHETICAL COMPANIES SCENARIO 3

\begin{tabular}{|l|c|c|c|c|c|c|}
\hline \multicolumn{1}{|c|}{ Sub-Factors } & Weights & A & B & C & D & E \\
\hline New to the World & 0.0066 & 0.495 & 0.33 & 0.396 & 0.198 & 0.231 \\
\hline New to the Company & 0.0034 & 0.221 & 0.187 & 0.17 & 0.119 & 0.102 \\
\hline Number of Awards & 0.005 & 0.2 & 0.325 & 0.25 & 0.2 & 0.2 \\
\hline Number of Honors & 0.005 & 0.2 & 0.275 & 0.25 & 0.225 & 0.2 \\
\hline Patents Granted & $\mathbf{0 . 5 7}$ & 39.9 & 28.5 & 34.2 & 25.65 & 39.9 \\
\hline Patents Filed & $\mathbf{0 . 2 4 7}$ & 17.29 & 11.115 & 14.82 & 12.35 & 18.525 \\
\hline Patents Cited & $\mathbf{0 . 1 3 3}$ & 9.31 & 5.32 & 7.98 & 5.32 & 9.31 \\
\hline Revenue from New Products & 0.01 & 0.8 & 0.4 & 0.6 & 0.2 & 0.4 \\
\hline Papers Published & 0.0055 & 0.11 & 0.165 & 0.2475 & 0.3575 & 0.165 \\
\hline Papers Presented & 0.0027 & 0.027 & 0.0675 & 0.1215 & 0.1485 & 0.108 \\
\hline Papers Cited & 0.0017 & 0.034 & 0.0425 & 0.051 & 0.0714 & 0.034 \\
\hline $\begin{array}{l}\text { Market Share of New } \\
\text { Products }\end{array}$ & 0.01 & 0.9 & 0.3 & & & \\
\hline Sum & 1 & $\mathbf{6 9 . 4 8 7}$ & $\mathbf{4 7 . 0 2 7}$ & $\mathbf{5 9 . 6 8 6}$ & $\mathbf{4 4 . 9 8 9 4}$ & $\mathbf{6 9 . 4 7 5}$ \\
\hline Ranking & & 1 & 4 & 3 & 5 & 2 \\
\hline
\end{tabular}

$=$ Top Priorities 
Appendix D-5: Innovativeness Index - Changes in Relative Importance of sub-factors (Scenario 4)

\begin{tabular}{|c|c|c|c|c|}
\hline \multicolumn{5}{|c|}{ SCENARIO 4} \\
\hline $\begin{array}{l}\text { Output } \\
\text { Indicators }\end{array}$ & Value & \multicolumn{2}{|l|}{ Sub-Factors } & $\begin{array}{l}\text { Sub-factors Value to the } \\
\text { Innovativeness Index }\end{array}$ \\
\hline \multirow{2}{*}{$\begin{array}{l}\text { Number of New } \\
\text { Products }\end{array}$} & \multirow{2}{*}{0.14} & New to the World & 0.66 & 0.0924 \\
\hline & & New to the Company & 0.34 & 0.0476 \\
\hline \multirow[t]{2}{*}{$\begin{array}{l}\text { Number of Innovation } \\
\text { Awards }\end{array}$} & \multirow{2}{*}{0.21} & Number of Awards & 0.5 & 0.105 \\
\hline & & Number of Honors & 0.5 & 0.105 \\
\hline \multirow[t]{3}{*}{ Number of Patents } & \multirow{3}{*}{0.2} & Patents Granted & 0.6 & 0.12 \\
\hline & & Patents Filed & 0.26 & 0.052 \\
\hline & & Patents Cited & 0.14 & 0.028 \\
\hline $\begin{array}{l}\text { Revenue From New } \\
\text { Products }\end{array}$ & 0.07 & $\begin{array}{l}\text { Revenue from New } \\
\text { Products }\end{array}$ & 1 & 0.07 \\
\hline \multirow[t]{3}{*}{ Number of Publications } & \multirow{3}{*}{0.28} & Papers Published & 0.55 & 0.154 \\
\hline & & Papers Presented & 0.27 & 0.0756 \\
\hline & & Papers Cited & 0.17 & 0.0476 \\
\hline $\begin{array}{l}\text { Market Share of New } \\
\text { Products }\end{array}$ & 0.09 & $\begin{array}{l}\text { Market Share of } \\
\text { New Products }\end{array}$ & 1 & 0.09 \\
\hline Total & 1 & & & 1 \\
\hline
\end{tabular}

$=$ Top Priorities

INNOVATIVENESS INDEX AND RANKINGS OF FIVE HYPOTHETICAL COMPANIES SCENARIO 4

\begin{tabular}{|l|c|c|c|c|c|c|}
\hline \multicolumn{1}{|c|}{ Sub-Factors } & Weights & A & B & C & D & E \\
\hline New to the World & 0.0924 & 6.93 & 4.62 & 5.544 & 2.772 & 3.234 \\
\hline New to the Company & 0.0476 & 3.094 & 2.618 & 2.38 & 1.666 & 1.428 \\
\hline Number of Awards & $\mathbf{0 . 1 0 5}$ & 4.2 & 6.825 & 5.25 & 4.2 & 4.2 \\
\hline Number of Honors & $\mathbf{0 . 1 0 5}$ & 4.2 & 5.775 & 5.25 & 4.725 & 4.2 \\
\hline Patents Granted & $\mathbf{0 . 1 2}$ & 8.4 & 6 & 7.2 & 5.4 & 8.4 \\
\hline Patents Filed & 0.052 & 3.64 & 2.34 & 3.12 & 2.6 & 3.9 \\
\hline Patents Cited & 0.028 & 1.96 & 1.12 & 1.68 & 1.12 & 1.96 \\
\hline Revenue from New Products & 0.07 & 5.6 & 2.8 & 4.2 & 1.4 & 2.8 \\
\hline Papers Published & $\mathbf{0 . 1 5 4}$ & 3.08 & 4.62 & 6.93 & 10.01 & 4.62 \\
\hline Papers Presented & 0.0756 & 0.756 & 1.89 & 3.402 & 4.158 & 3.024 \\
\hline Papers Cited & 0.0476 & 0.952 & 1.19 & 1.428 & 1.9992 & 0.952 \\
\hline $\begin{array}{l}\text { Market Share of New } \\
\text { Products }\end{array}$ & 0.09 & 8.1 & 2.7 & 5.4 & 1.35 & 2.7 \\
\hline Sum & 1 & $\mathbf{5 0 . 9 1 2}$ & $\mathbf{4 2 . 4 9 8}$ & $\mathbf{5 1 . 7 8 4}$ & $\mathbf{4 1 . 4 0 0 2}$ & $\mathbf{4 1 . 4 1 8}$ \\
\hline Ranking & & 2 & 3 & 1 & 5 & 4 \\
\hline
\end{tabular}

$=$ Top Priorities 
Appendix D-6: Innovativeness Index - Changes in Company Outputs (Scenario 5)

DESIRABILITY VALUE COMPANY A WITH CHANGES IN PERFORMANCE METRICS SCENARIO 5

\begin{tabular}{|c|c|c|c|c|}
\hline Sub-Factors & & \multicolumn{3}{|c|}{ COMPANY A } \\
\hline & Weights & Profiles & Desirability & Value \\
\hline New Products New to the World & 0.13 & 600 & 75 & 9.75 \\
\hline $\begin{array}{l}\text { New Products New to the } \\
\text { Company }\end{array}$ & 0.07 & 800 & 65 & 4.55 \\
\hline Number of Awards & 0.05 & 600 & 40 & 2 \\
\hline Number of Honors & 0.05 & 600 & 40 & 2 \\
\hline Number of Patents Granted & 0.08 & 600 & 70 & 5.6 \\
\hline Number of Patents Filed & 0.04 & 800 & 70 & 2.8 \\
\hline Number of Patents Cited & 0.02 & 700 & 70 & 1.4 \\
\hline Revenue from New Products & 0.28 & 480,000 & 80 & 22.4 \\
\hline Number of Papers Published & 0.04 & 50 & 20 & 0.8 \\
\hline Number of Papers Presented & 0.02 & 40 & 10 & 0.2 \\
\hline Number of Papers Cited & 0.01 & 40 & 20 & 0.2 \\
\hline Market Share of New Products & 0.21 & $\begin{array}{c}20 \% \\
\text { (Decreased by } 70 \%)\end{array}$ & 20 & 4.2 \\
\hline Total & 1 & & $\begin{array}{l}\text { Innovativeness } \\
\text { Index }\end{array}$ & 55.9 \\
\hline
\end{tabular}

$\square=$ Changes of Values 
Appendix D-7: Innovativeness Index - Changes in Company Outputs (Scenario 6)

DESIRABILITY VALUE COMPANY E WITH CHANGES IN PERFORMANCE METRICS SCENARIO 6

\begin{tabular}{|c|c|c|c|c|}
\hline Sub-Factors & & \multicolumn{3}{|c|}{ COMPANY E } \\
\hline & Weights & Profiles & Desirability & Value \\
\hline New Products New to the World & 0.13 & 6 & 75 & 4.55 \\
\hline New Products New to the Company & 0.07 & 9 & 65 & 2.1 \\
\hline Number of Awards & 0.05 & 7 & 40 & 2 \\
\hline Number of Honors & 0.05 & 6 & 40 & 2 \\
\hline Number of Patents Granted & 0.08 & 25 & 70 & 5.6 \\
\hline Number of Patents Filed & 0.04 & 30 & 70 & 3 \\
\hline Number of Patents Cited & 0.02 & 40 & 70 & 1.4 \\
\hline Revenue from New Products & 0.28 & 400 & 80 & 11.2 \\
\hline Number of Papers Published & 0.04 & $\begin{array}{c}50 \\
\text { (increased by 43) }\end{array}$ & 50 & 2 \\
\hline Number of Papers Presented & 0.02 & $\begin{array}{c}60 \\
\text { (increased by 53) }\end{array}$ & 45 & 0.9 \\
\hline Number of Papers Cited & 0.01 & $\begin{array}{c}45 \\
\text { (increased by 39) }\end{array}$ & 35 & 0.35 \\
\hline Market Share of New Products & 0.21 & $30 \%$ & 20 & 6.3 \\
\hline Total & 1 & & $\begin{array}{c}\text { Innovativeness } \\
\text { Index }\end{array}$ & 41.4 \\
\hline
\end{tabular}

$=$ Changes of Values 
Appendix D-8: Innovativeness Index - Changes in Company Outputs (Scenario 7)

DESIRABILITY VALUE COMPANY D WITH CHANGES IN PERFORMACE METRICS SCENARIO 7

\begin{tabular}{|c|c|c|c|c|}
\hline Sub-Factors & & \multicolumn{3}{|c|}{ COMPANY D } \\
\hline & Weights & Profiles & Desirability & Value \\
\hline New Products New to the World & 0.13 & $\begin{array}{c}72 \\
\text { (Increased by 62) }\end{array}$ & 75 & 9.75 \\
\hline New Products New to the Company & 0.07 & $\begin{array}{c}48 \\
\text { (Increased by } 30)\end{array}$ & 70 & 4.9 \\
\hline Number of Awards & 0.05 & 12 & 40 & 2 \\
\hline Number of Honors & 0.05 & 8 & 45 & 2.25 \\
\hline Number of Patents Granted & 0.08 & 8 & 45 & 3.6 \\
\hline Number of Patents Filed & 0.04 & 12 & 50 & 2 \\
\hline Number of Patents Cited & 0.02 & 8 & 40 & 0.8 \\
\hline Revenue from New Products & 0.28 & $\begin{array}{c}120,000 \\
\text { (increased by } 100 \text { million) }\end{array}$ & 80 & 22.4 \\
\hline Number of Papers Published & 0.04 & 72 & 65 & 2.6 \\
\hline Number of Papers Presented & 0.02 & 60 & 55 & 1.1 \\
\hline Number of Papers Cited & 0.01 & 68 & 42 & 0.42 \\
\hline Market Share of New Products & 0.21 & $\begin{array}{c}90 \% \\
\text { (Increased by } 75 \%)\end{array}$ & 40 & 18.9 \\
\hline Total & 1 & & $\begin{array}{l}\text { Innovativeness } \\
\text { Index } \\
\end{array}$ & 70.72 \\
\hline
\end{tabular}

$=$ Changes of Values 
Appendix D-9: Innovativeness Index - Intel and AMD

\begin{tabular}{|l|c|c|c|}
\hline \multicolumn{1}{|c|}{ INTEL } & 2010 & 2011 & 2012 \\
\hline Total Revenue & 42 & 51 & 49 \\
\hline Notebook Processor & $34.70 \%$ & $35.70 \%$ & $35.40 \%$ \\
\hline Server Processor & $17.50 \%$ & $17.10 \%$ & $18.20 \%$ \\
\hline Desktop Processor & $20.30 \%$ & $19.50 \%$ & $19.50 \%$ \\
\hline Sum & $72.50 \%$ & $72.30 \%$ & $73.10 \%$ \\
\hline Revenue from Processor & 30.45 & 36.873 & 35.819 \\
\hline Total Revenue in 3 years & \multicolumn{3}{|c|}{142 Billion } \\
\hline Total Revenue in 3 years from Processors & \multicolumn{3}{|c|}{103.1 Billion } \\
\hline
\end{tabular}

\begin{tabular}{|l|c|c|c|}
\hline \multicolumn{1}{|c|}{ AMD } & 2010 & 2011 & 2012 \\
\hline Total Revenue & 6.5 & 6.6 & 5.4 \\
\hline Notebook Processor & $19.90 \%$ & $26 \%$ & $28.50 \%$ \\
\hline Server Processor & $6 \%$ & $5.15 \%$ & $5.34 \%$ \\
\hline Desktop Processor & $33.70 \%$ & $30.20 \%$ & $24.70 \%$ \\
\hline Sum & $59.60 \%$ & $61.35 \%$ & $58.54 \%$ \\
\hline Revenue from Processor & 3.874 & 4.0491 & 3.16116 \\
\hline Total Revenue in 3 years & \multicolumn{3}{|c|}{18.5 Billion } \\
\hline Total Revenue in 3 years from Processors & 11.08 Billion \\
\hline
\end{tabular}

CHARACTERISTICS OF INTEL AND AMD

\begin{tabular}{|l|c|c|}
\hline \multicolumn{1}{|c|}{ COMPANY } & Intel & AMD \\
\hline New Products New to the World & 53 & 36 \\
\hline New Products New to the Company & 422 & 160 \\
\hline Number of Awards & 37 & 25 \\
\hline Number of Honors & Data not available & Data not available \\
\hline Number of Patents Granted & 550 & 100 \\
\hline Number of Patents Filed & 773 & 368 \\
\hline Number of Patents Cited & Data not available & Data not available \\
\hline Revenue from New Products & 91.759 Billion & 7.867 Billion \\
\hline Number of Papers Published & Data not available & Data not available \\
\hline Number of Papers Presented & Data not available & Data not available \\
\hline Number of Papers Cited & Data not available & Data not available \\
\hline Market Share of New Products & $90 \%$ & $30 \%$ \\
\hline
\end{tabular}


PERFORMANCE METRICS OF INTEL AND AMD

\begin{tabular}{|l|c|c|}
\hline \multicolumn{1}{|c|}{ COMPANY } & Intel & AMD \\
\hline New Products New to the World & $10 \%$ & $13 \%$ \\
\hline New Products New to the Company & $79 \%$ & $58 \%$ \\
\hline Number of Awards & 1 per 27 & 1 per 7 \\
\hline Number of Honors & Data not available & Data not available \\
\hline Number of Patents Granted & 1 per 2 & 1 per 2 \\
\hline Number of Patents Filed & 1 per 2 & $>1$ \\
\hline Number of Patents Cited & Data not available & Data not available \\
\hline Revenue from New Products & $64 \%$ & $42 \%$ \\
\hline Number of Papers Published & $>1$ & $>1$ \\
\hline Number of Papers Presented & Data not available & Data not available \\
\hline Number of Papers Cited & Data not available & Data not available \\
\hline Market Share of New Products & $62.3 \%$ & $21.3 \%$ \\
\hline
\end{tabular}

DESIRABILITY VALUES OF INTEL AND AMD'S PERFORMANCE METRICS

\begin{tabular}{|l|c|c|}
\hline \multicolumn{1}{|c|}{ COMPANY } & Intel & AMD \\
\hline New Products New to the World & 30 & 35 \\
\hline New Products New to the Company & 65 & 58 \\
\hline Number of Awards & 65 & 50 \\
\hline Number of Honors & Data not available & Data not available \\
\hline Number of Patents Granted & 80 & 80 \\
\hline Number of Patents Filed & 80 & 80 \\
\hline Number of Patents Cited & Data not available & Data not available \\
\hline Revenue from New Products & 80 & 60 \\
\hline Number of Papers Published & 10 & 10 \\
\hline Number of Papers Presented & Data not available & Data not available \\
\hline Number of Papers Cited & Data not available & Data not available \\
\hline Market Share of New Products & 60 & 20 \\
\hline
\end{tabular}

INNOVATIVENESS INDEX AND RANKINGS OF INTEL AND AMD

\begin{tabular}{|l|c|c|c|}
\hline \multicolumn{1}{|c|}{ Sub-Factors } & Weights & INTEL & AMD \\
\hline New to the World & $\mathbf{0 . 1 3}$ & 3.9 & 4.55 \\
\hline New to the Company & 0.07 & 4.55 & 4.06 \\
\hline Number of Awards & 0.05 & 3.25 & 2.5 \\
\hline Number of Honors & 0.05 & 0 & 0 \\
\hline Patents Granted & 0.08 & 6.4 & 6.4 \\
\hline Patents Filed & 0.04 & 3.2 & 3.2 \\
\hline Patents Cited & 0.02 & 0 & 0 \\
\hline Revenue from New Products & $\mathbf{0 . 2 8}$ & 22.4 & 16.8 \\
\hline Papers Published & 0.04 & 0.4 & 0.4 \\
\hline Papers Presented & 0.02 & 0 & 0 \\
\hline Papers Cited & 0.01 & 0 & 0 \\
\hline Market Share of New Products & $\mathbf{0 . 2 1}$ & 12.6 & 4.2 \\
\hline Sum & 1 & $\mathbf{5 6 . 7}$ & $\mathbf{4 2 . 1 1}$ \\
\hline Ranking & & 1 & 2 \\
\hline
\end{tabular}

- Top Priority 